
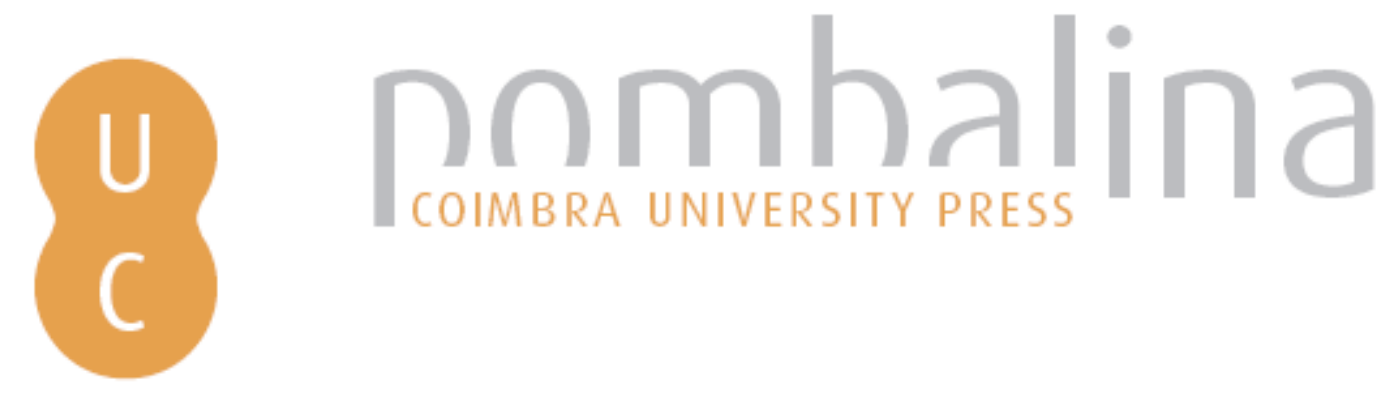

\title{
Desenho: percepção e investigação formal
}
Autor(es):
Olaio, António
Publicado por: Imprensa da Universidade de COimbra
URL persistente:
URl:http://hdl.handle.net/10316.2/2641
DOI:
DOI:http://dx.doi.org/10.14195/978-989-26-0344-5

Accessed : $\quad$ 19-May-2017 17:41:21

A navegação consulta e descarregamento dos títulos inseridos nas Bibliotecas Digitais UC Digitalis, UC Pombalina e UC Impactum, pressupõem a aceitação plena e sem reservas dos Termos e Condições de Uso destas Bibliotecas Digitais, disponíveis em https://digitalis.uc.pt/pt-pt/termos.

Conforme exposto nos referidos Termos e Condições de Uso, o descarregamento de títulos de acesso restrito requer uma licença válida de autorização devendo o utilizador aceder ao(s) documento(s) a partir de um endereço de IP da instituição detentora da supramencionada licença.

Ao utilizador é apenas permitido o descarregamento para uso pessoal, pelo que o emprego do(s) título(s) descarregado(s) para outro fim, designadamente comercial, carece de autorização do respetivo autor ou editor da obra.

Na medida em que todas as obras da UC Digitalis se encontram protegidas pelo Código do Direito de Autor e Direitos Conexos e demais legislação aplicável, toda a cópia, parcial ou total, deste documento, nos casos em que é legalmente admitida, deverá conter ou fazer-se acompanhar por este aviso.

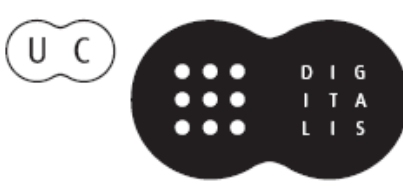




\section{António Olaio}

$$
\text { d e }
$$

\section{Percepção e Investigação Formal}
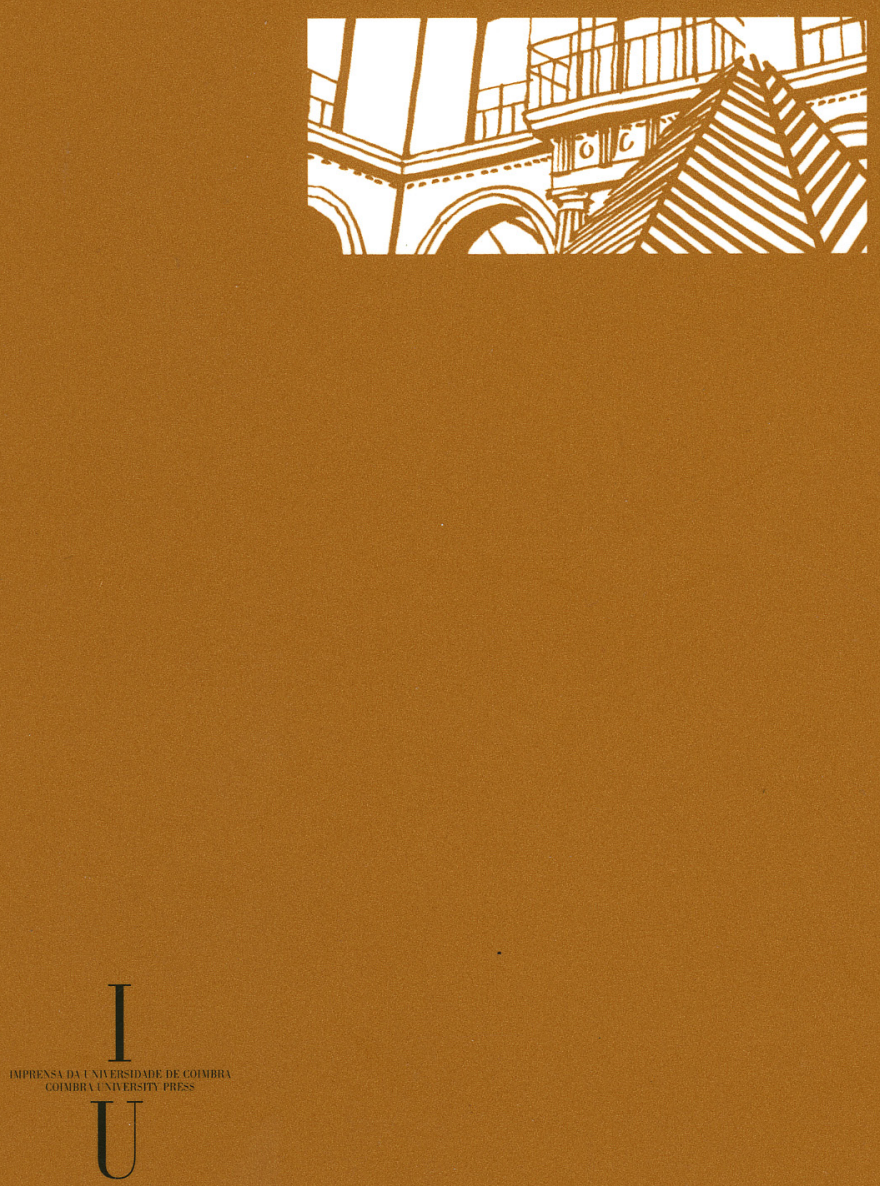

- colmbra 2006 
(Página deixada propositadamente em branco) 

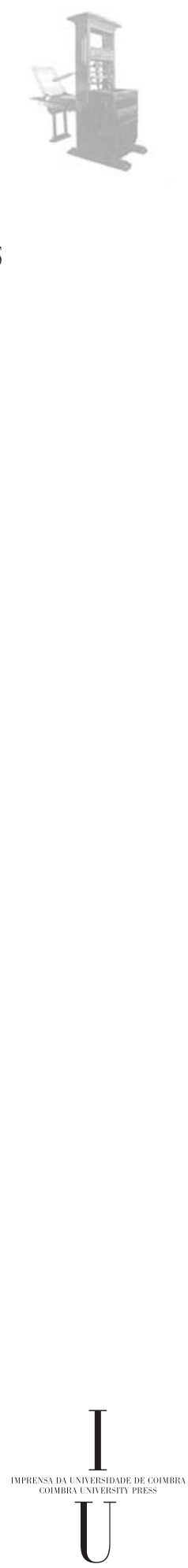
COORDENAÇÃO EDITORIAL

Imprensa da Universidade de Coimbra

CONCEPÇÃO GRÁFICA

António Barros

PAGINAÇÃO

SerSilito - Maia

EXECUÇÃO GRÁFICA

SerSilito • Maia

ISBN

972-8704-68-2

ISBN

972-8704-68-2

DOI

http://dx.doi.org/10.14195/978-989-26-0343-8

DEPÓSITO LEGAL

243188/06

(C) MAIO 2006, IMPRENSA DA UNIVERSIDADE DE COIMBRA 
António Olaio

DE

Percepção e Investigação Formal

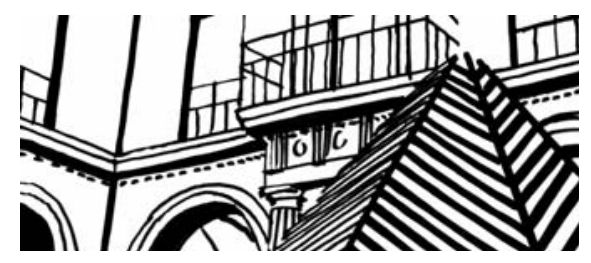


(Página deixada propositadamente em branco) 


\section{Índice}

Ensinar desenho num curso de arquitectura

pág. 9

Representação do espaço urbano....................................................... pág. 15

Experiências caligráficas a partir da representação da mão............... pág. 53

Da plasticidade caligráfica à plasticidade compositiva ...................... pág. 65

Composições tendo o rosto como ponto de partida ........................ pág. 99

O desenho motivado pelo conceito ................................................... pág. 109

Da representação à desconstrução das formas ................................... pág. 119

Exploração formal e poética da ambiguidade

entre a bidimensionalidade e a sugestão espacial ............................. pág. 149

Exploração das potencialidades de transformação formal

da estrutura de um cubo................................................................. pág. 163

A maquete como instrumento de expressão plástica e conceptual.... pág. 181 
(Página deixada propositadamente em branco) 


\section{Ensinar desenho num curso de arquitectura}

É incontornável, ao ponto de ser já um lugar comum, referir o desenho na sua qualidade de desígnio.

E, mais do que encarar esta condição de desígnio, importa reflectir sobre o que é que isso quer dizer.

E, sobretudo, aqui importa entender o que é que isso quer dizer quando, frequentemente, nos cursos de arquitectura é confiado o ensino do desenho a artistas plásticos.

Nesta qualidade de desígnio, não será propriamente na plasticidade dos desenhos enquanto objectos, nem enquanto imagens com determinadas qualidades gráficas, que manifestarão as potencialidades das artes plásticas no ensino do desenho para futuros arquitectos.

Se o desenho é desígnio, na formação dos arquitectos, os artistas plásticos participam nos desígnios da arquitectura.

Mas, como será certamente evidente, ensinar desenho a futuros arquitectos não é, de forma alguma, sinónimo de ensinar artes plásticas, não é o campo das manifestações das artes plásticas que é aqui o objectivo do ensino do desenho.

Logo, teremos que concluir que a resposta para o lugar do artista plástico na formação dos arquitectos, estará na procura das essencialidades comuns às artes plásticas e à arquitectura.

Para além do facto de terem em comum as qualidades de transformadores, de criadores de novas relações perceptivas e vivenciais com a realidade que lhes são reconhecidas, importa aqui, onde tratamos do ensino, da formação, 
sobretudo reflectir sobre o que existirá de comum entre a qualidade de artista plástico e a de arquitecto, nas suas essências conceptuais.

Poder-se-ia sintetizar, dando a resposta, simplesmente referindo a criativi10 dade.

Mas, como todas as palavras que, pelo uso frequente, parecem esvaziar-se de sentido, ou perder a sua capacidade significante, melhor do que referir a criatividade, o que poderá dizer tudo, ou esconder que, de facto, não se estará a dizer nada, importa procurar onde, aqui, encontraremos o seu sentido.

E, assim, numa reflexão mais aprofundada, encontraremos certamente o espaço comum entre as artes e a arquitectura, na capacidade de pensar a forma, de relacionar a forma e as ideias, ou, melhor um espaço onde a inteligência se manifesta num campo em que formas e ideias não são entidades distintas.

É evidente que um artista plástico e um arquitecto não são a mesma coisa, até porque um arquitecto opera no campo do útil, relaciona a arte com a utilidade.

Mas têm em comum a capacidade de relacionar diferentes realidades e as transformar em forma.

Ao contrário das discussões áridas entre forma e conteúdo, os artistas e os arquitectos sabem ou sentem (o que aqui é a mesma coisa) a ideia das formas e a forma das ideias, e é neste domínio que residem os seus campos.

Mas o principal desafio no papel de um artista plástico como professor de desenho num curso de arquitectura é contribuir para a formação do arquitecto, potenciando a sua qualidade de artista plástico, ou, melhor, participar do ensino da arquitectura continuando a ser, nesse papel, um artista plástico e, ao mesmo tempo, não ensinar o que habitualmente entendemos por artes plásticas.

Nas essencialidades comuns entre a arquitectura e as artes plásticas, em processos de ensino, ou, melhor, de catalisação da aprendizagem, aqui, a aprendizagem do desenho, ou, melhor, a aprendizagem pelo desenho, manifesta as qualidades da arte (artes plásticas ou arquitectura) para além da especificidade das suas diferentes manifestações.

Como realização pessoal (permito-me aqui referi-la pela importância da motivação na eficácia pedagógica), ensinar a aprender pelo desenho num curso 
de arquitectura, é uma experiência estética única, e uma manifestação da vitalidade da arte para além de quaisquer definições.

\section{Objectivos da disciplina de desenho II}

O desenho num curso de arquitectura é simultaneamente uma disciplina exterior e interior à arquitectura. Simultaneamente autónoma, na consciência das qualidades específicas da experimentação pelo desenho, e uma disciplina que procura desenvolver qualidades para uma maior operatividade do desenho nas suas diversas manifestações na prática do projecto, na prática da arquitectura.

Nesta simultaneidade da proximidade e do distanciamento, a disciplina de desenho, não sendo o lugar onde se ensina arquitectura, é o lugar onde se desenvolvem capacidades de concepção.

Ensinar-se a desenhar num curso de arquitectura é ensinar-se a pensar pelo desenho, começando pelo desenho como apreensão, e a apreensão já é pensamento, pois vê-se conhecendo e reconhecendo, até ao desenho como instrumento da concepção, ou, mesmo, como a própria concepção.

De uma forma mais radical, poder-se-ia dizer que na disciplina de desenho não se aprende a desenhar, aprende-se a pensar, e a pensar enquanto concepção onde os desenhos são meros veículos. E a elementaridade gráfica dos desenhos, mais do que a tornar visível, destina-se a tornar inteligível.

Enquanto que, na cadeira de Projecto, é na realidade da relação entre as formas e as funcionalidades que os alunos encontrarão as ideias condutoras dos seus projectos, na disciplina de Desenho II, os exercícios são maioritariamente desenvolvidos na linguagem autónoma do desenho, enquanto desenvolvimento de capacidades, mais do que resolução de questões. E, assim, nos exercícios desta disciplina, os alunos desenvolvem capacidades plásticas e conceptuais cujo sentido lúdico será também uma estratégia pedagógica.

$\mathrm{Na}$ origem da ideia de arte enquanto fazer, nesta disciplina desenvolvem-se sobretudo potencialidades no domínio dos processos de concepção. 
A circunstância de ser uma disciplina de desenho no âmbito de um curso de arquitectura e não de artes visuais, poder-lhe-á conferir uma maior clareza de propósitos, no sentido de não encarar o desenho ou os desenhos enquanto imagens, ou fins em si, mas sim, enquanto instrumentos de projecto, o que não será mais do que a própria definição de desenho.

Encarando o desenho como espaço de desenvolvimento de capacidades, mais do que lugar de resolução de questões específicas, esta disciplina procura ser um contributo para o desenvolvimento da artisticidade da arquitectura.

E, a bidimensionalidade do suporte tradicional dos desenhos, nos exercícios aqui desenvolvidos, é encarada como lugar de experimentação de vários aspectos complementares da relação entre formas e ideias.

Assim, esta disciplina tem como principal objectivo possibilitar ao aluno um campo de experimentação que permita o desenvolvimento de uma relação com o desenho onde se produza uma empatia entre o manual e o mental, ou, melhor, onde, pela prática do desenho, se dilua a distância entre cérebro e manualidade.

\section{Enquadramento curricular}

Sendo as disciplinas de desenho desenvolvimento de faculdades, esta projecta-se fora dela e é a sua vocação ser incompleta, mas estrategicamente incompleta.

E, assim, as disciplinas de desenho continuam nas cadeiras de projecto.

Este estar ao serviço, na disciplina de desenho, confere-lhe uma extrema importância, e a consciência de não ser um fim em si, entendendo o desenho, enquanto concepção, como um processo onde tudo se transforma ao relacionar-se.

E o ensino do desenho de e para a arquitectura cumpre-se ao potenciar essa transformação.

Assim, o ensino do desenho, aqui, não sendo projecto, prevê o projecto e é nessa previsão que intui as faculdades a desenvolver. 
Não existindo relações óbvias entre os exercícios de desenho nesta disciplina e o trabalho específico do projecto, é, simultaneamente, na afirmação de uma autonomia disciplinar do desenho que vimos a forma de melhor contribuir para

a prática do Projecto, procurando uma relação de complementaridade e evitando, na relação com as disciplinas de Projecto, qualquer promiscuidade metodológica.

Estando atenta ao desenvolvimento dos exercícios da disciplina de Projecto II, procurando frequentemente e exercícios cuja poética se situe no campo de possibilidades levantado pelas questões desenvolvidas em Projecto II, a disciplina de Desenho II não se esgota num relacionamento com a disciplina de Projecto do mesmo ano lectivo.

Sendo a última disciplina de desenho do curriculum deste curso de arquitectura é sobretudo na globalidade de um processo de formação do arquitecto que esta disciplina se situa, procurando lançar, com os seus exercícios, sementes para um maior domínio e riqueza dos processos criativos.

\section{Metodologia}

A disciplina de Desenho II tendo como principal objectivo o desenvolvimento de capacidades criativas na relação entre formas e ideias, potenciando a relação com o Projecto, sobretudo no desenvolvimento de capacidades para o Projecto e, simultaneamente, não procurando mimetizar os seus processos, procura atingir os seus objectivos com exercícios onde se desenvolvem diferentes aspectos do desenho enquanto instrumento de concepção:

- A autonomia gráfica do desenho, encarando o desenho como linguagem e, na multiplicidade de soluções gráficas, um investimento nas suas potencialidades comunicativas

- A percepção dos espaços pelo desenho, não na pura representação da sua visibilidade, mas sim como forma de os conhecer e, assim poder melhor 
potenciar uma futura transformação (a desenvolver nos exercícios das disciplinas de Projecto).

- A representação no desenvolvimento da sensibilidade para a forma

- A capacidade de partir da representação como estímulo para autonomia compositiva do desenho.

- A capacidade de criar formas e composições, sem qualquer referente exterior, na autonomia dos elementos plásticos do desenho.

- A percepção das estruturas das formas a representar como motor para a invenção formal.

- A estrutura de formas volumétricas elementares como catalizadoras da sua própria transformação, encarando a sua geometria como dinâmica potencialmente transformadora, vendo as formas para além da fixação estática dos seus contornos.

- A capacidade de desenvolver a relação entre ideias e formas, na diluição de qualquer dicotomia entre significado e significante. No estabelecer uma relação criativa entre ideias, ponto de partida, e a criação de forma, o desenho afasta-se de uma mera relação ilustrativa com a realidade encarada como exterior, relacionando-se sobretudo com a essência das ideias e não com as meras aparências.

- O desenho como forma de comunicação. O desenho como lugar de simulação de novas realidades.

- O desenho para além da realidade dos desenhos, como porta para um espaço de experiência artística e fruição estética. 
REPRESENTAÇÃO DO ESPAÇO URBANO 
(Página deixada propositadamente em branco) 
Nestes exercícios os desenhos resultam de uma representação espacial, procurando a representação da realidade da presença física nos espaços, mais do que um mero ponto de vista.

Mais do que um olhar sobre os espaços, procura-se aqui uma aproximação à realidade perceptiva do é habitar os espaços a representar.

Para além da procura da síntese da representação dos lugares, salientar a importância dos seus elementos, como sendo relevantes para a caracterização dos espaços.

Os alunos, nestes exercícios, procurarão diferentes graus de síntese, adequando as caligrafias às intencionalidades dos desenhos. 


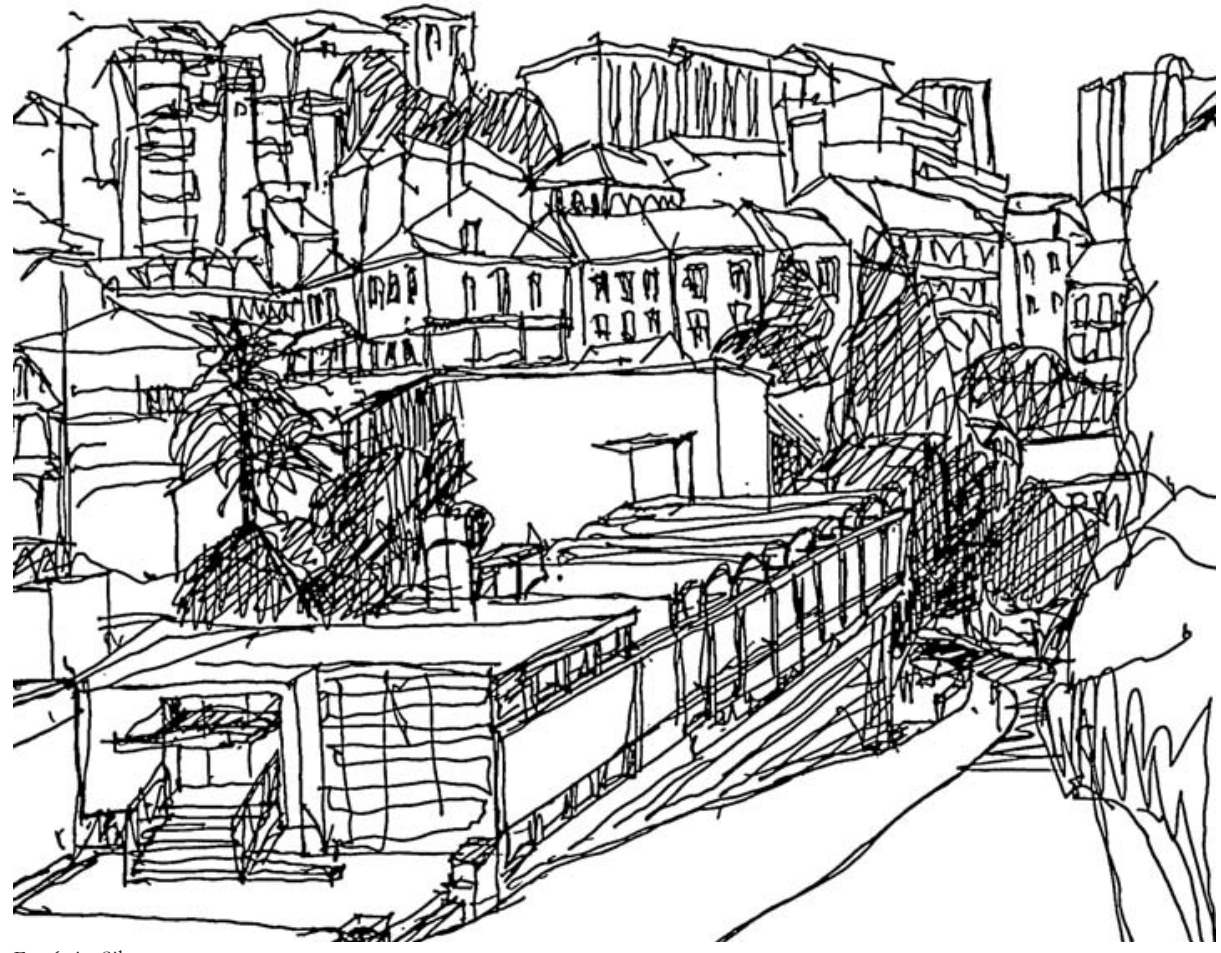

Eugénio Silva

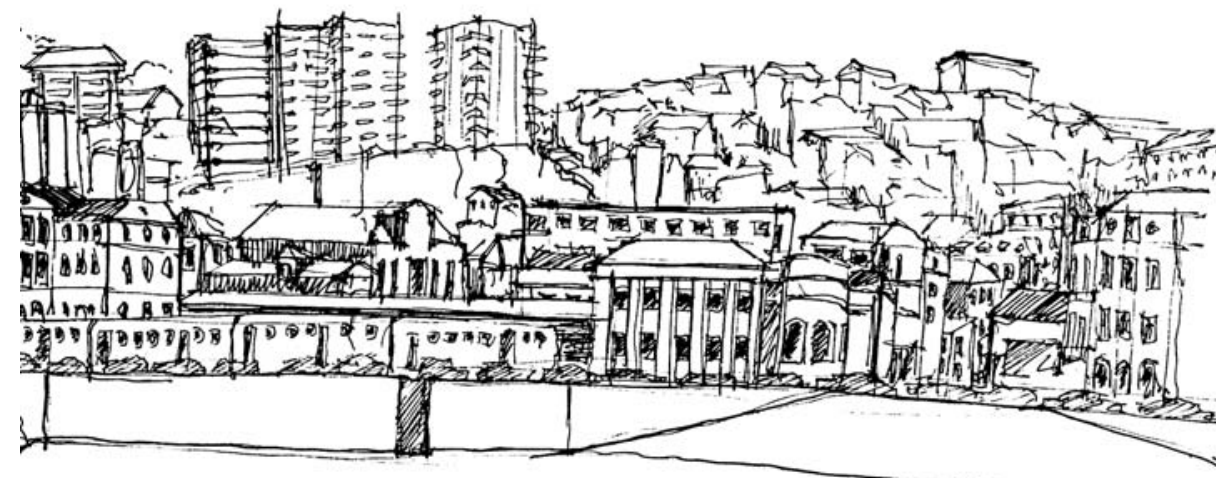



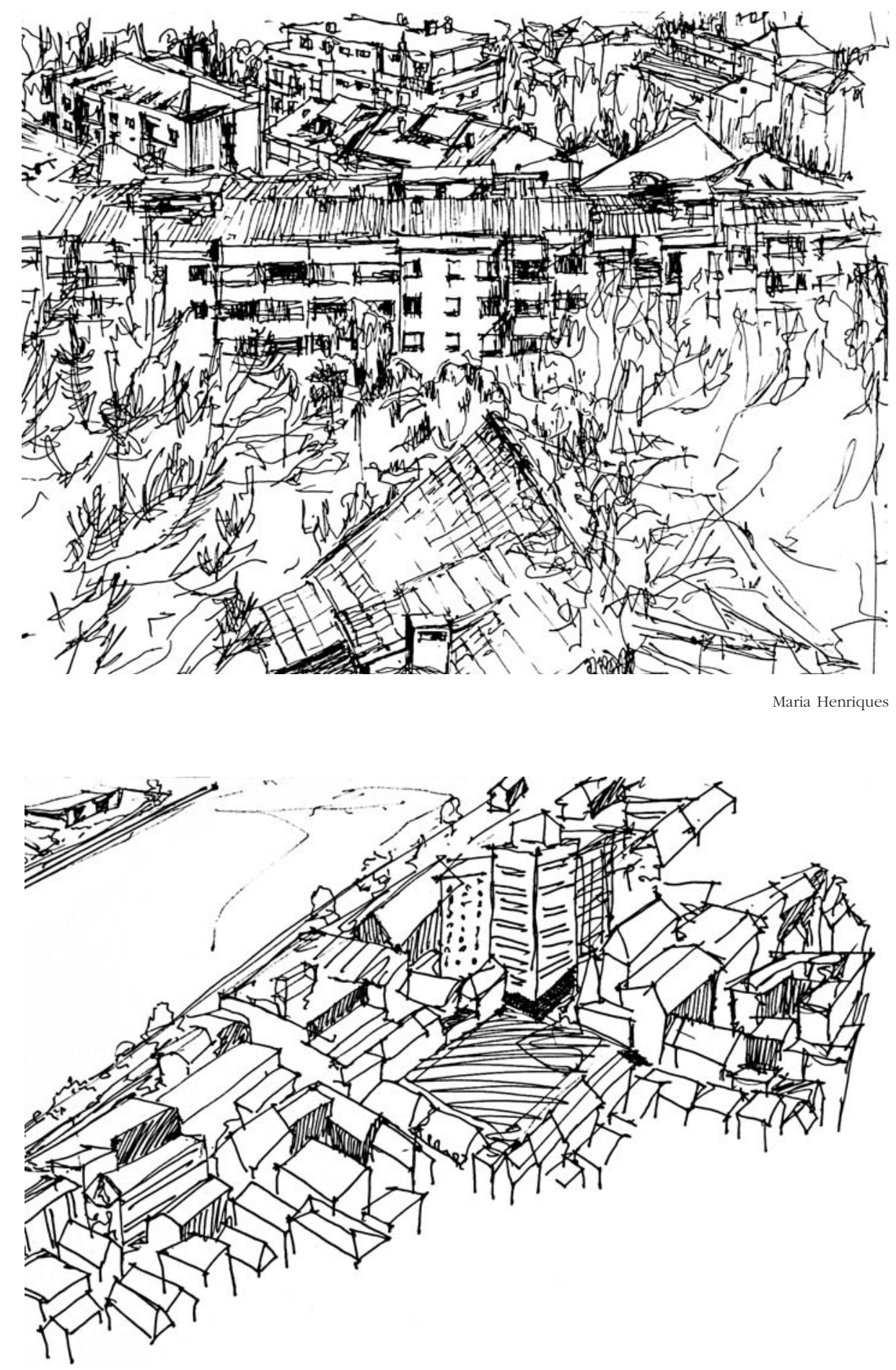


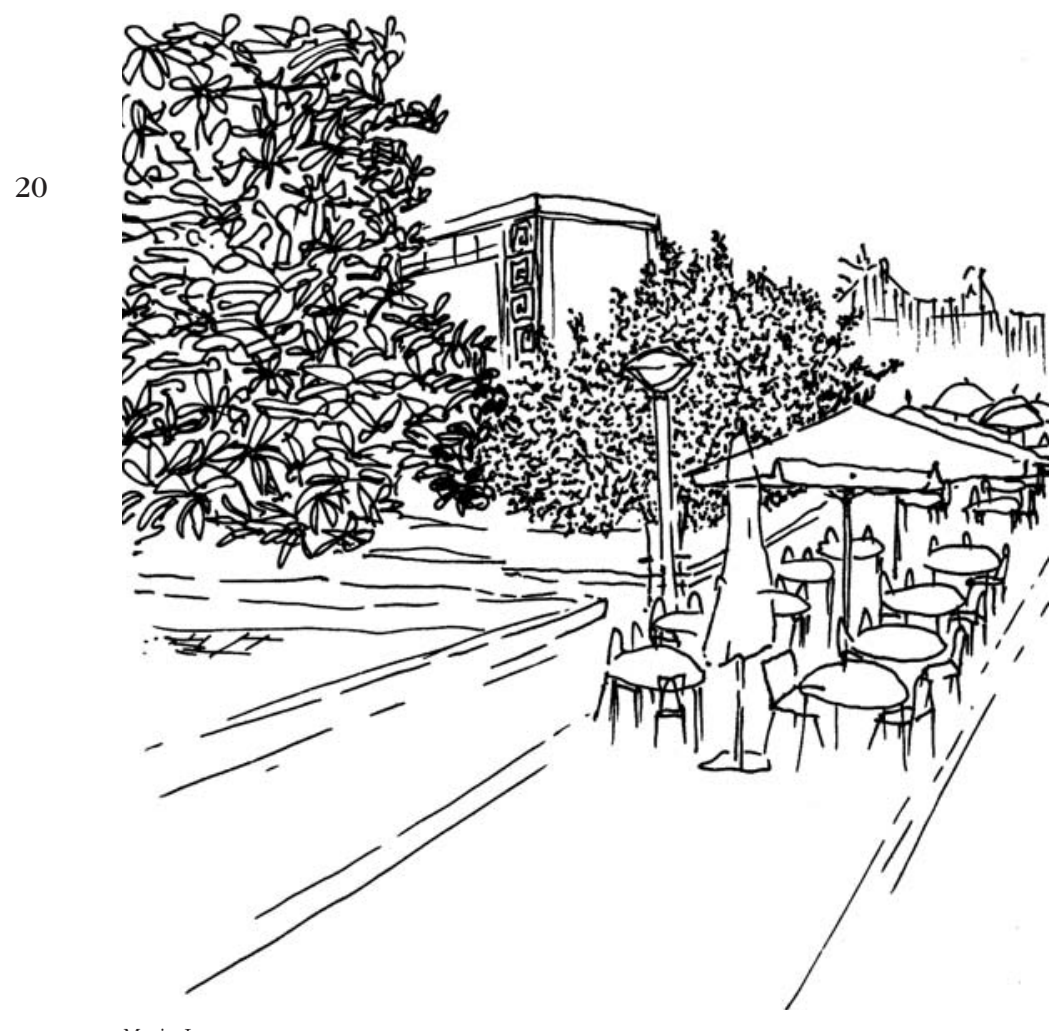

Maria Joana

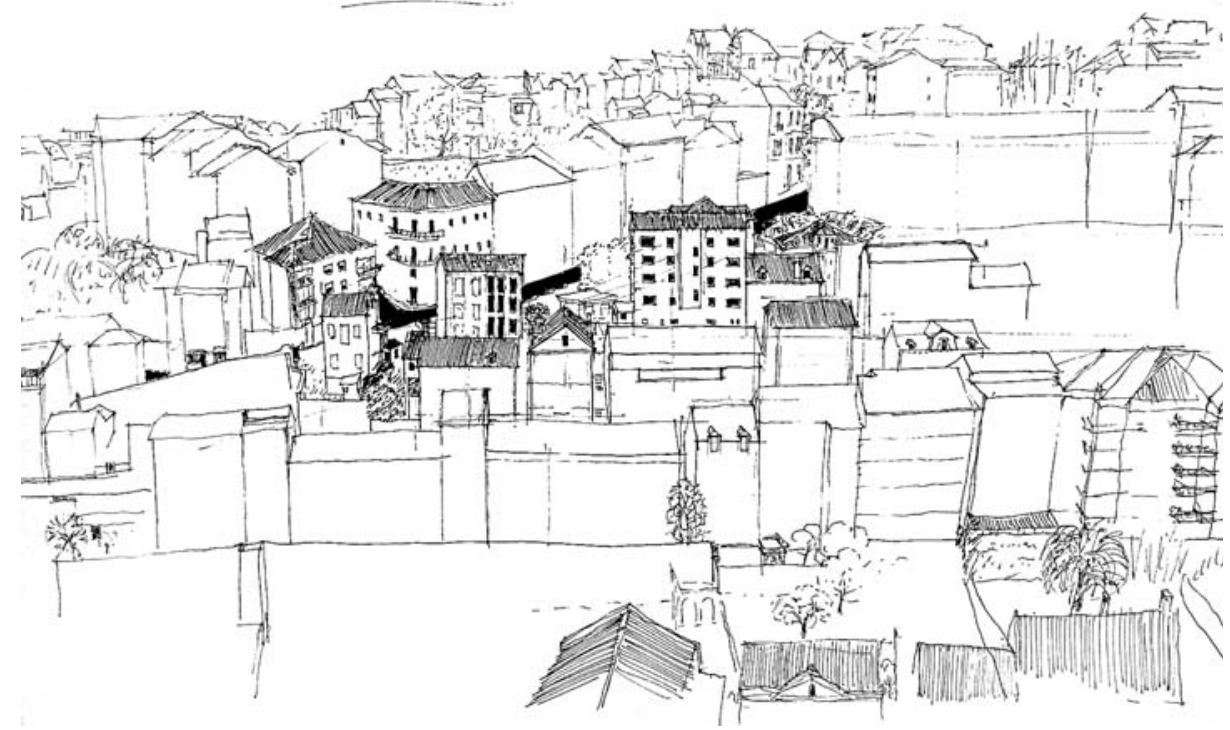

Miguel Amado 


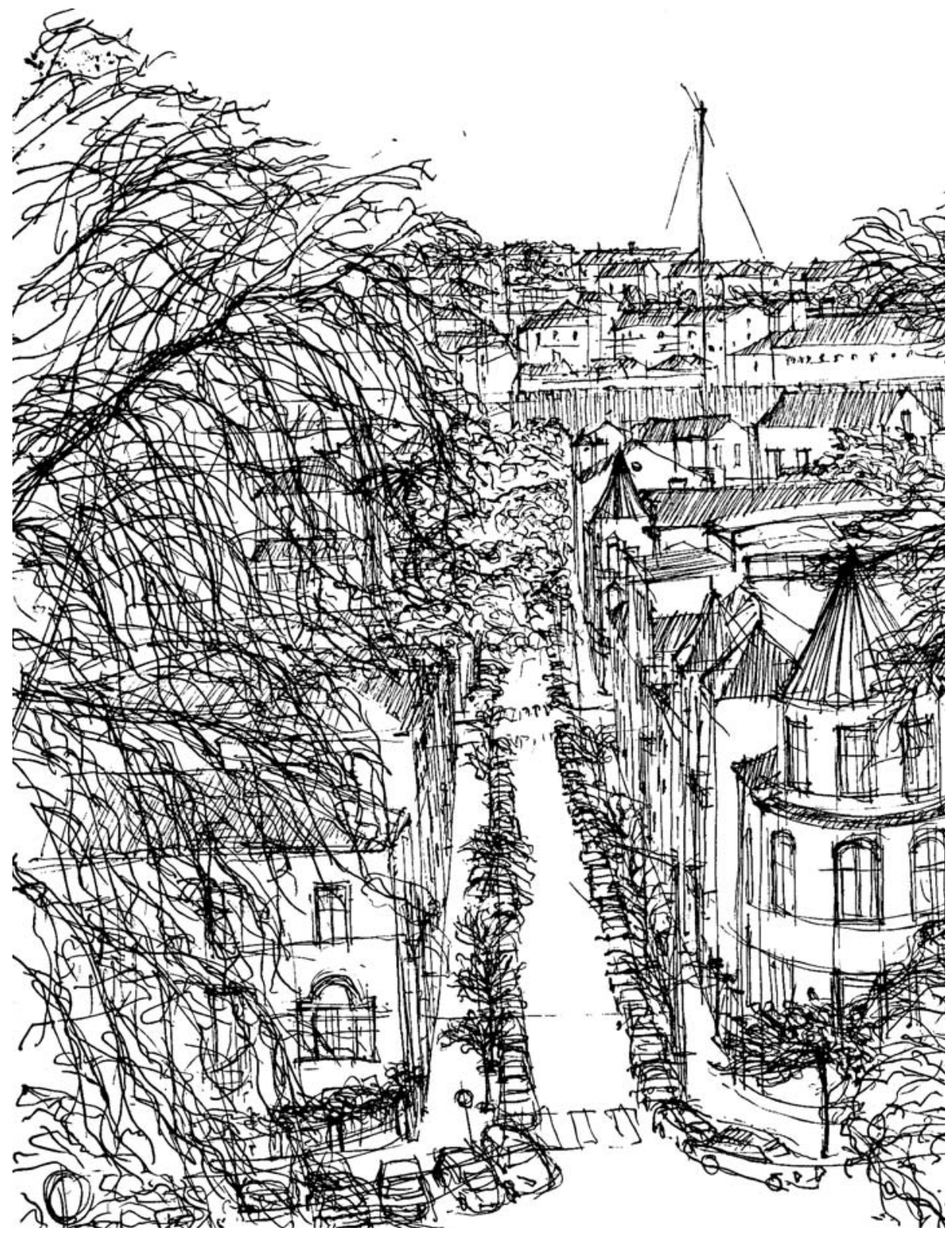




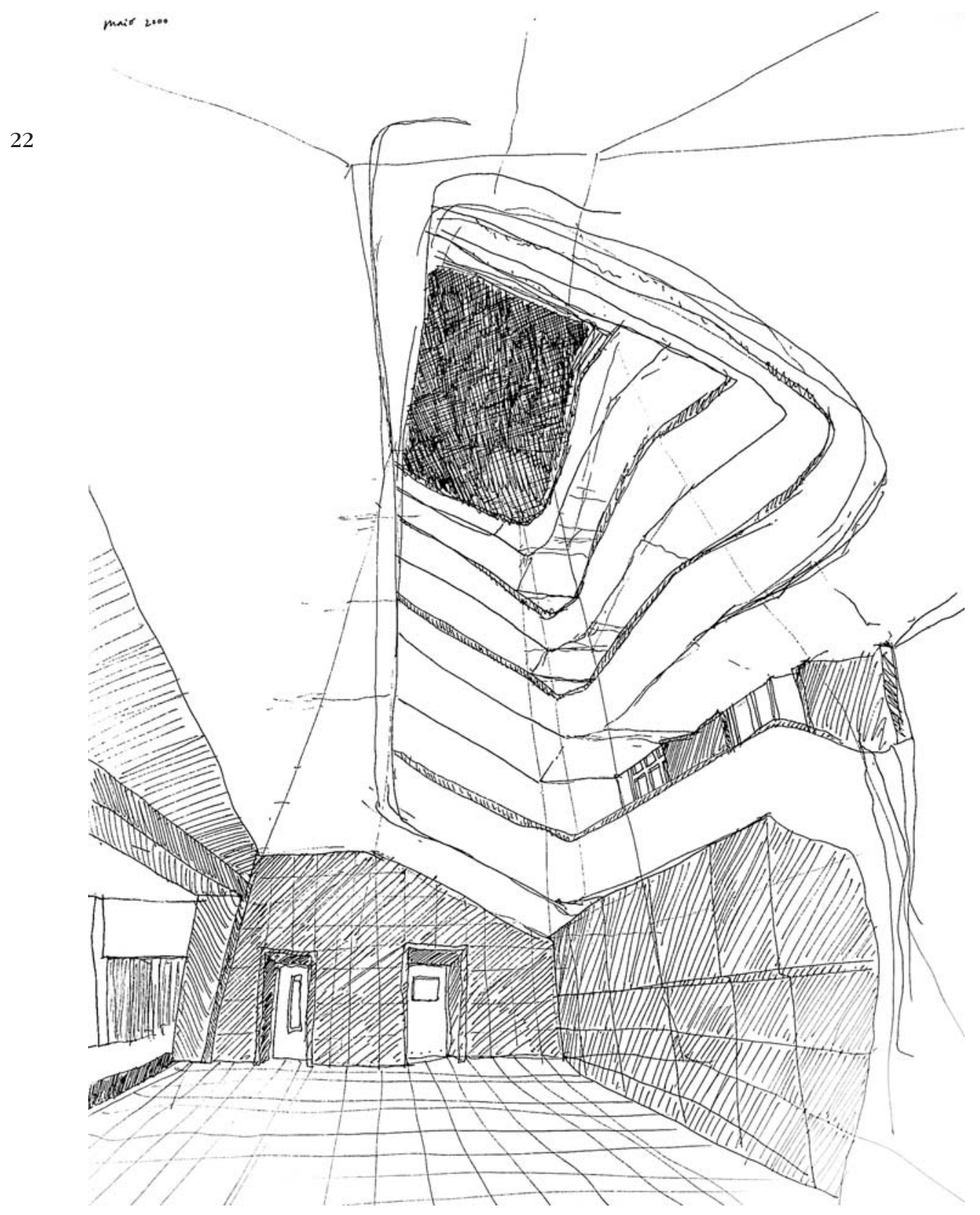

Miguel Amado 

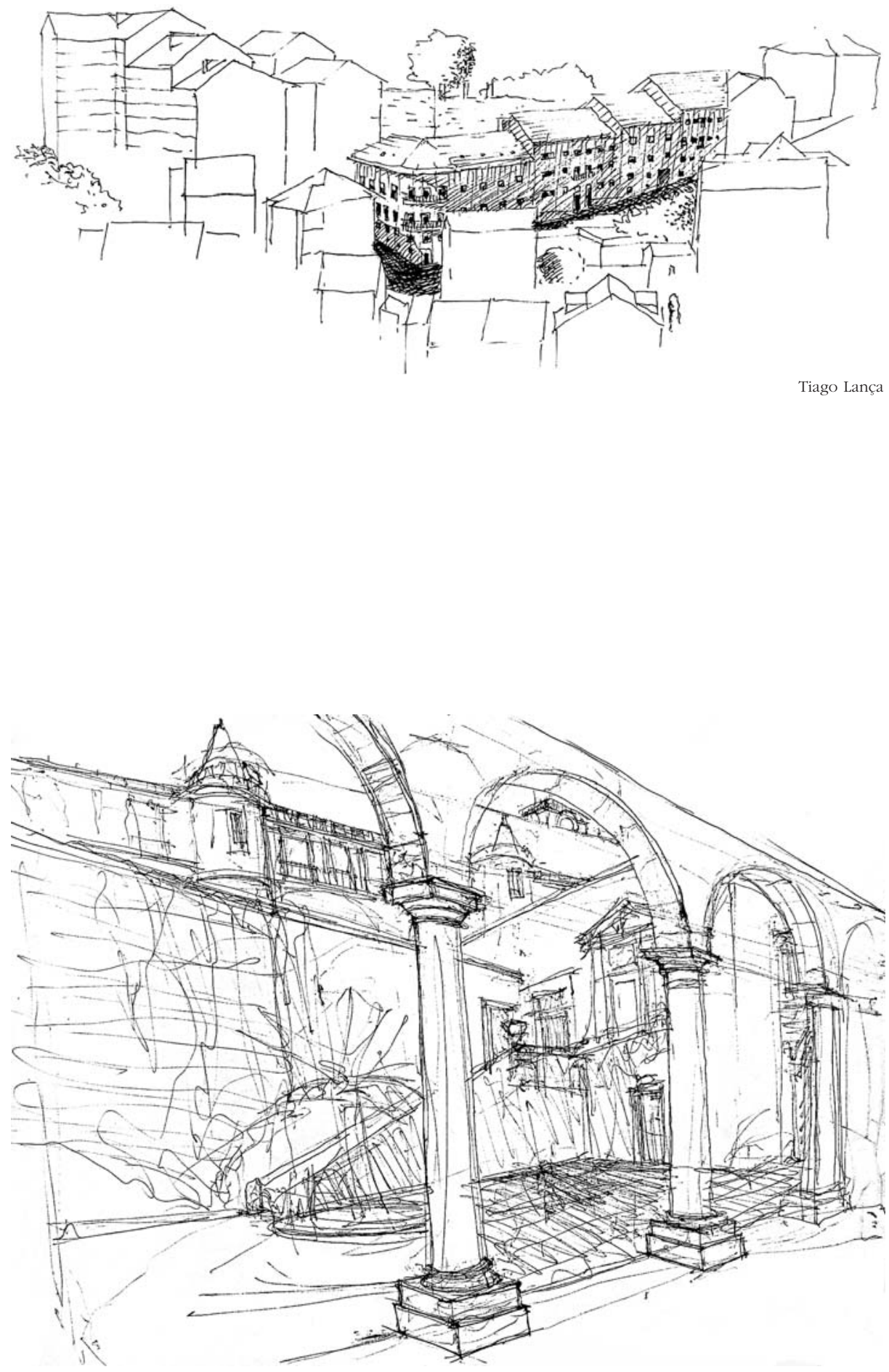


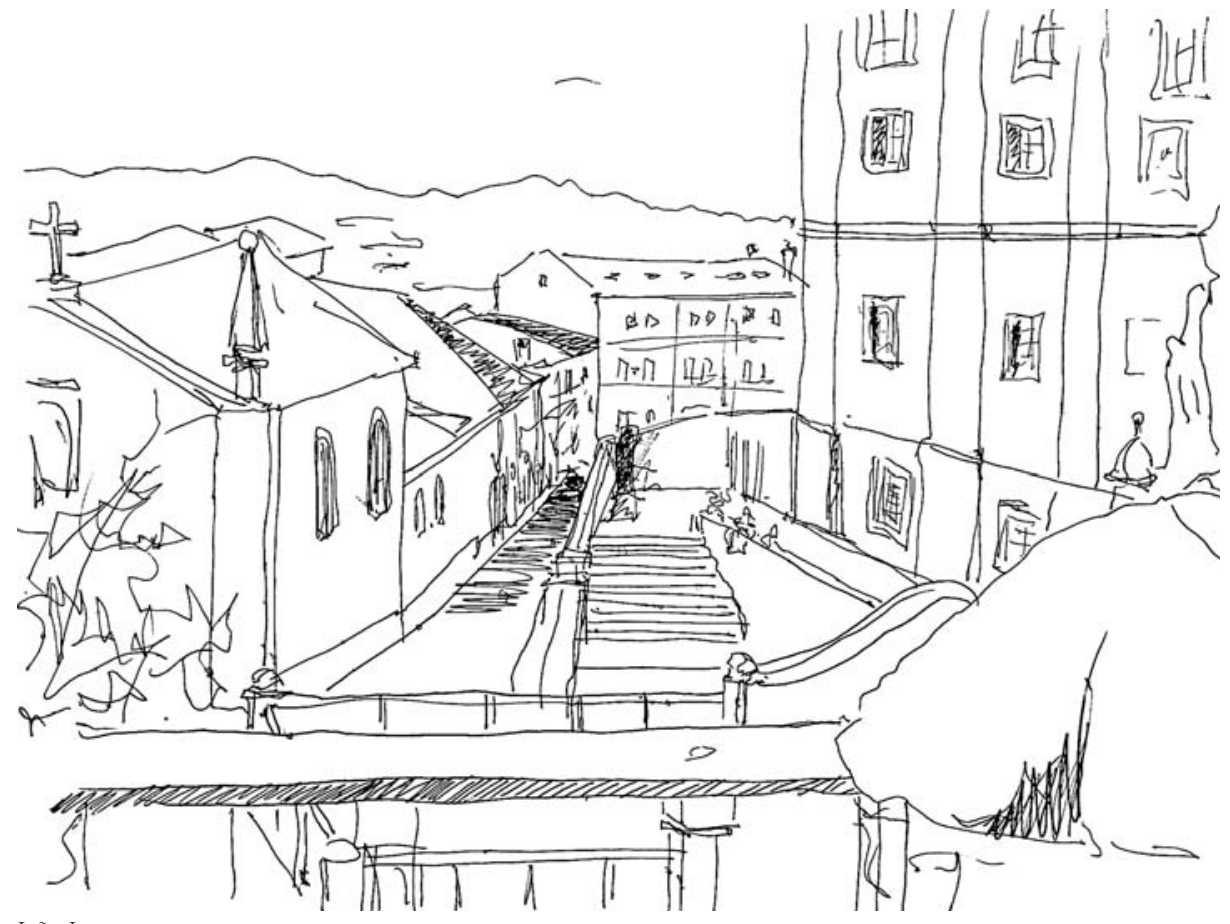

João Lopes

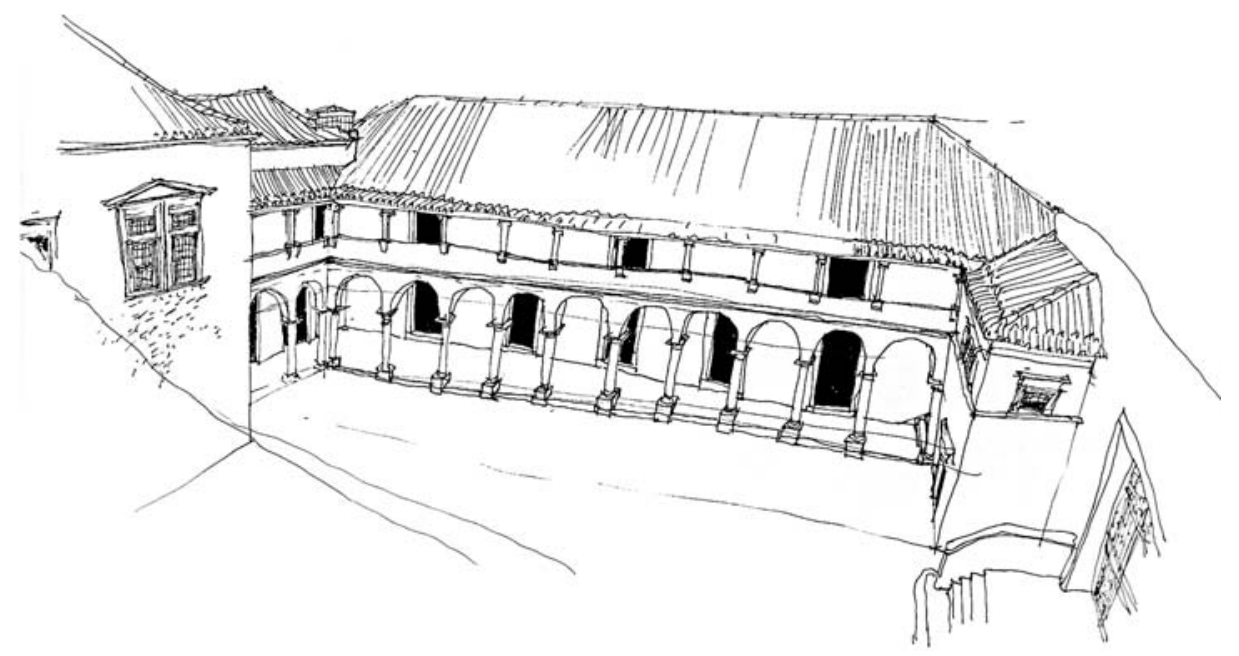

Miguel Amado 


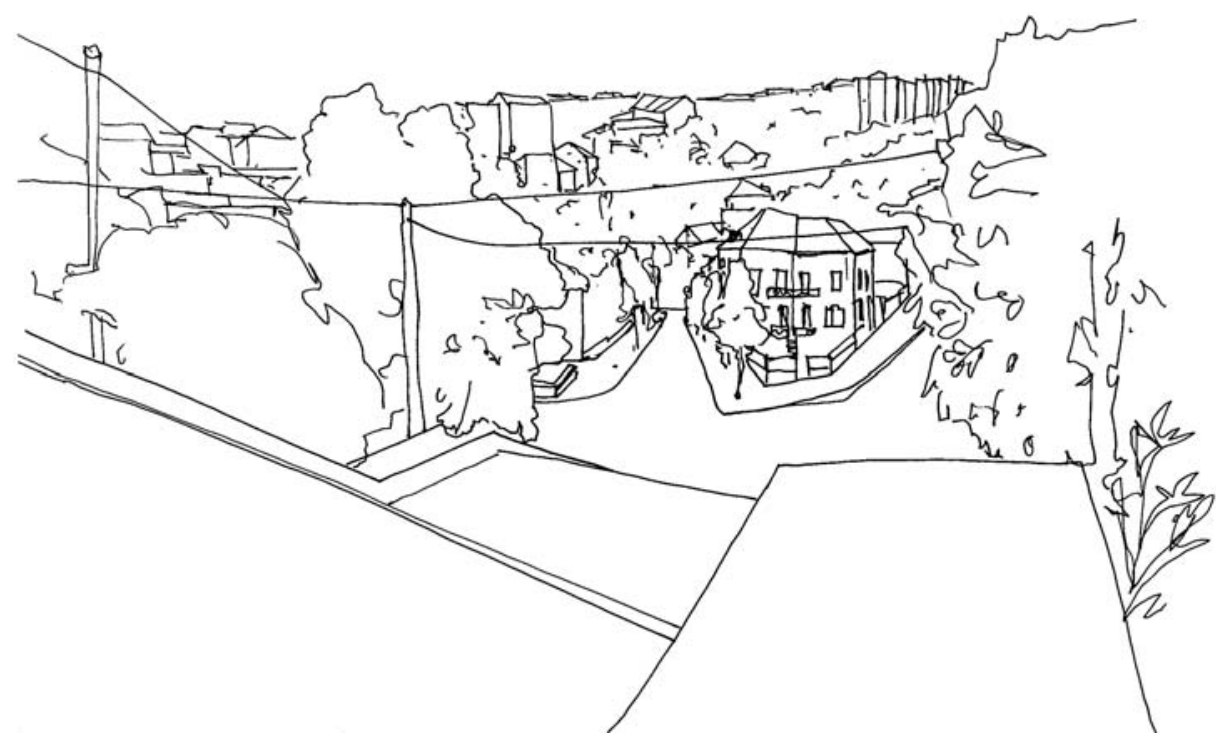

Manuela Rebocho

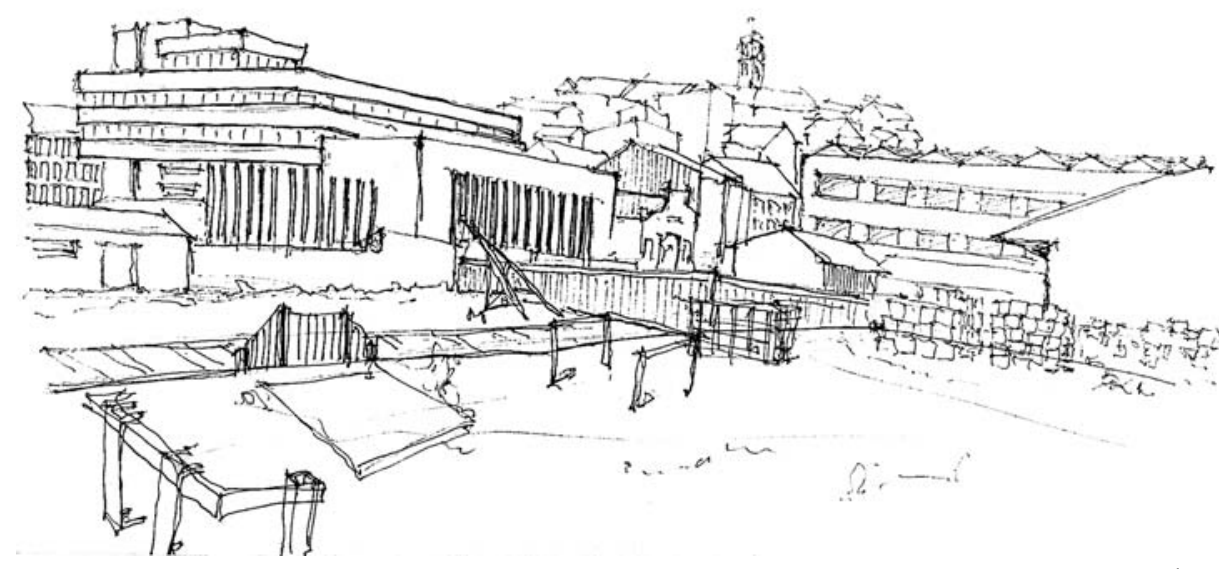

Tiago Fiadeiro 


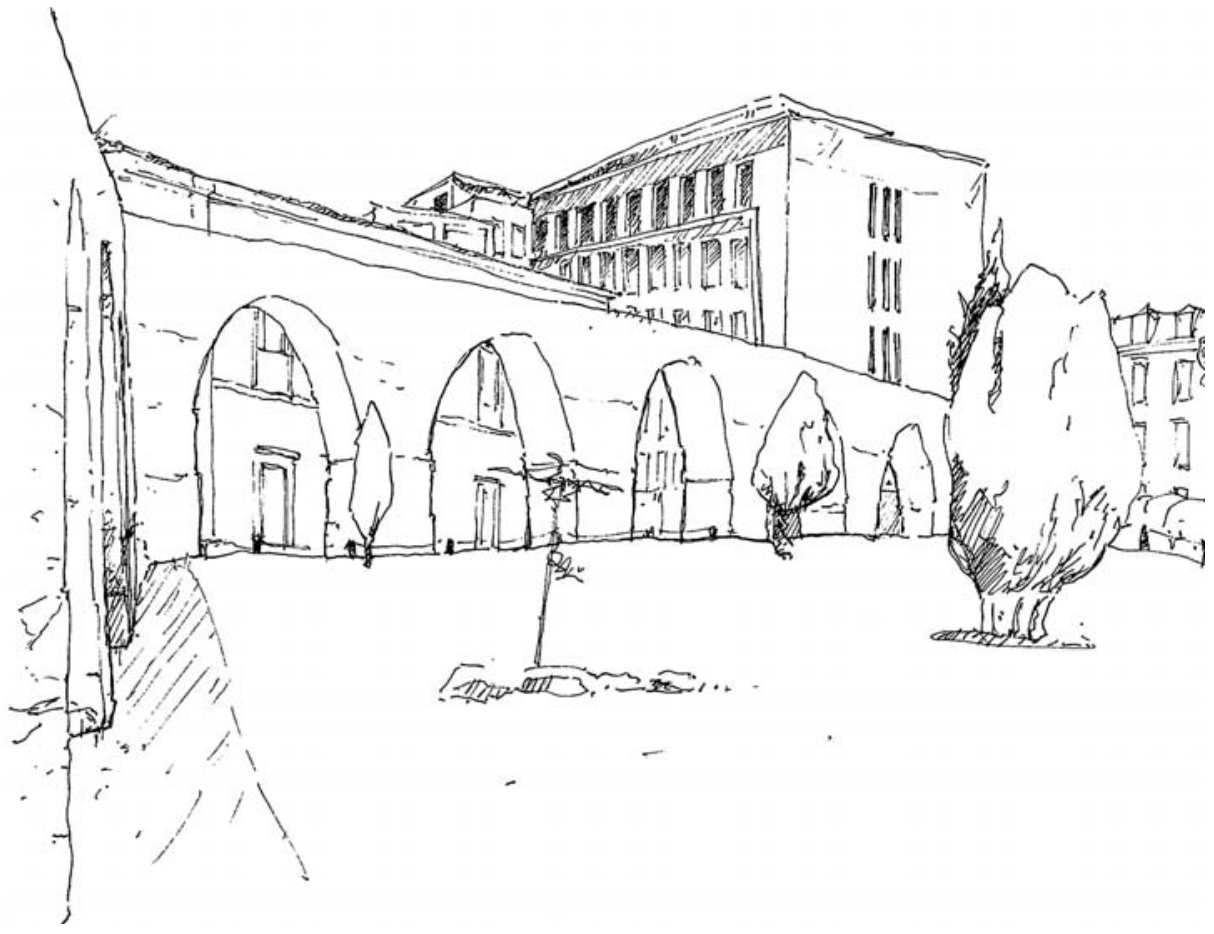

André Rocha

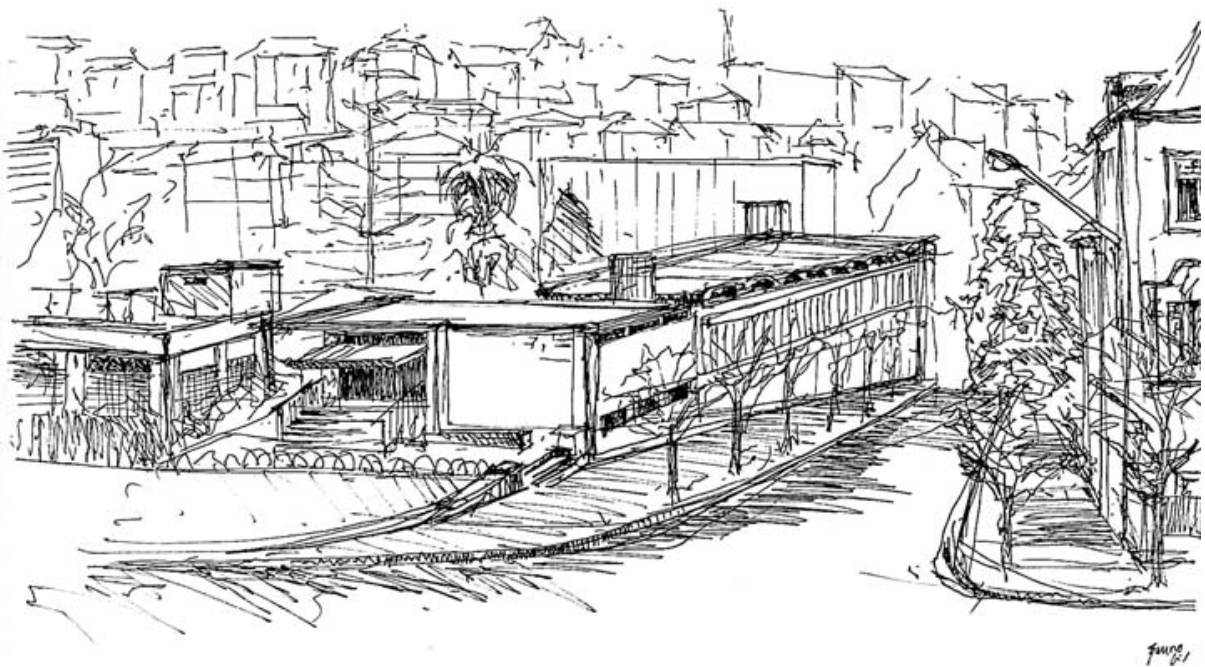




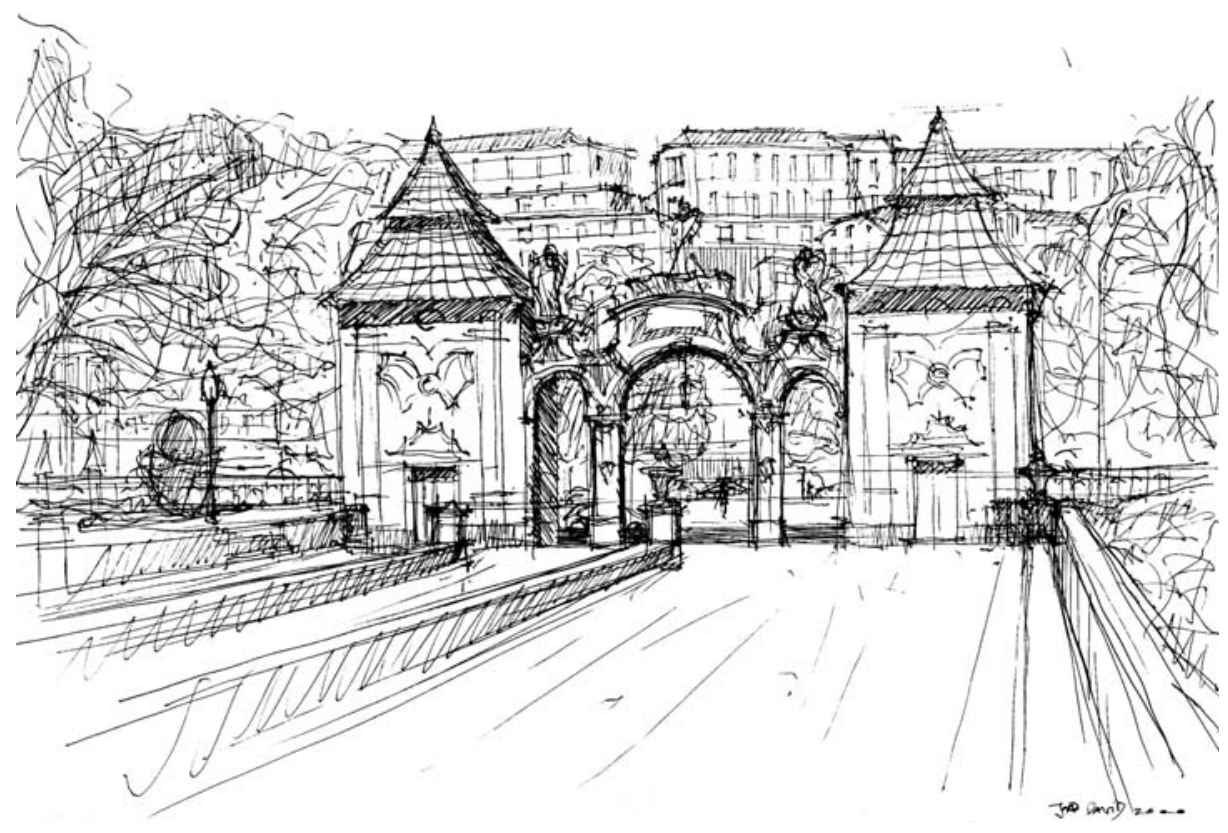

Tiago Fiadeiro

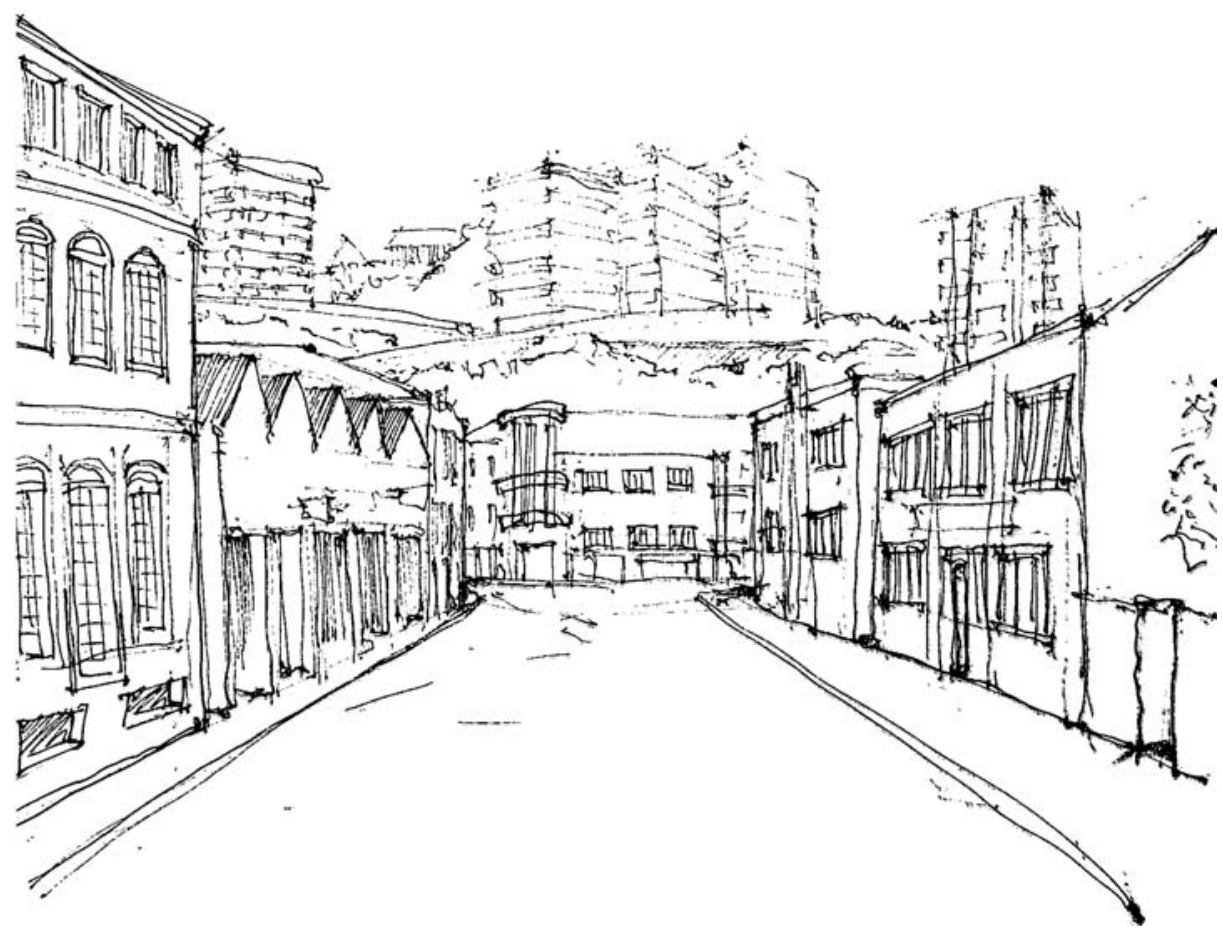

Tiago Fiadeiro 


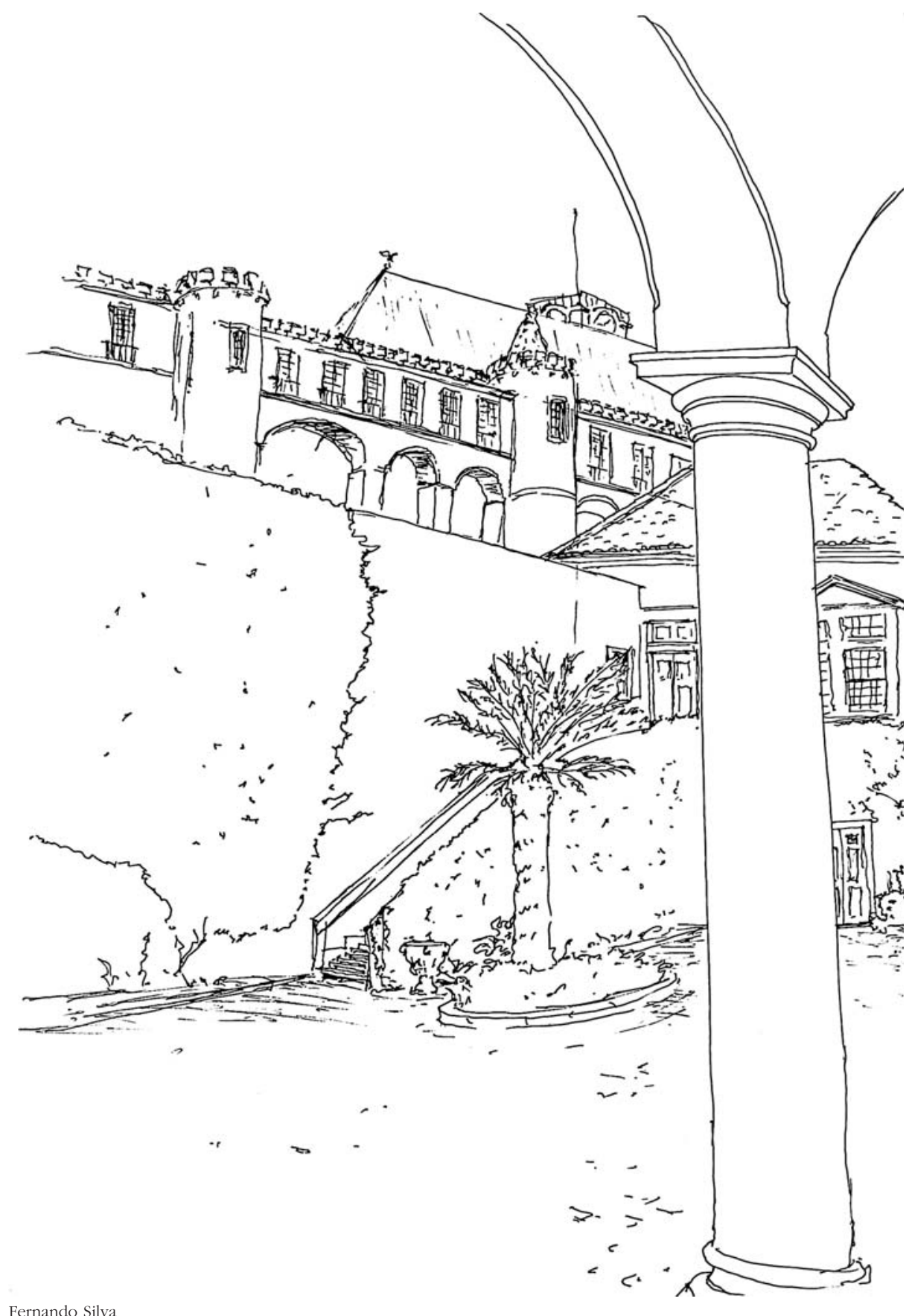

Fernando Silva 


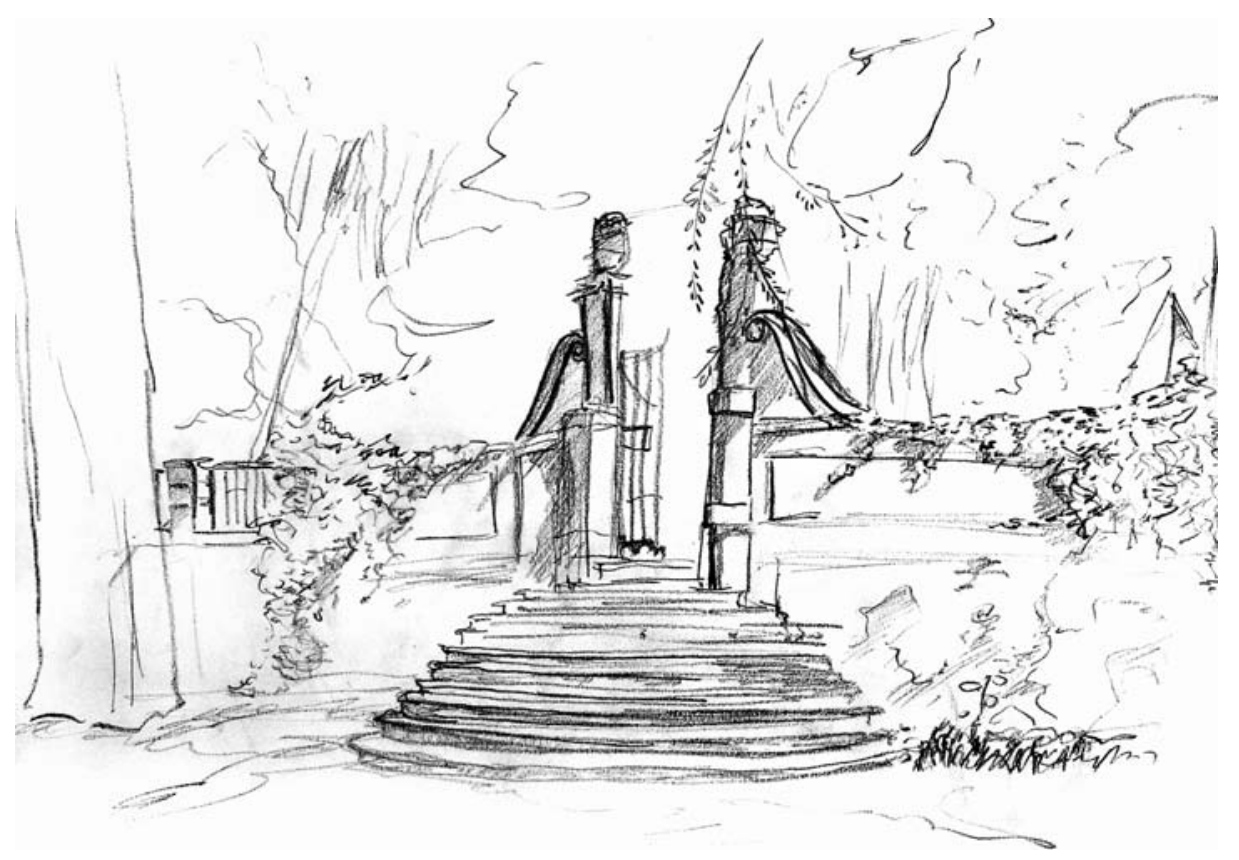

Marco Godinho

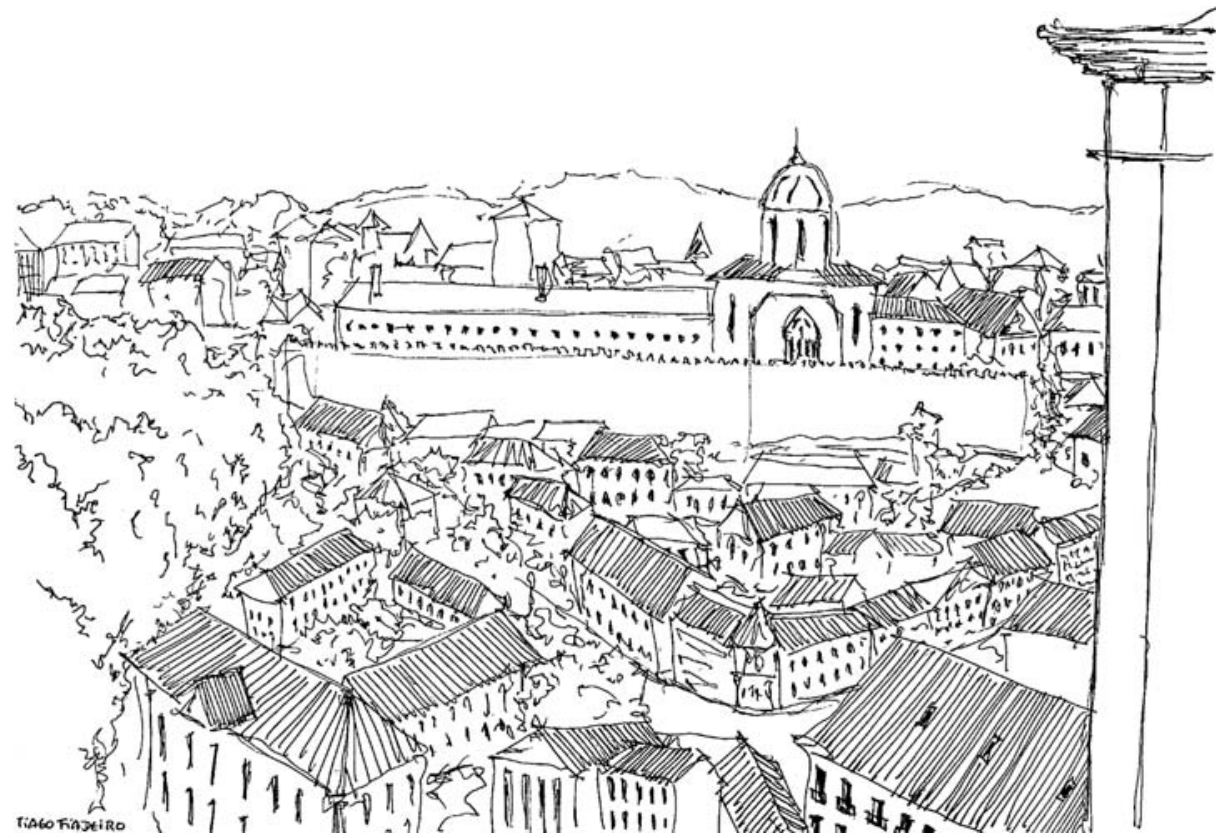

Tiago Fiadeiro 


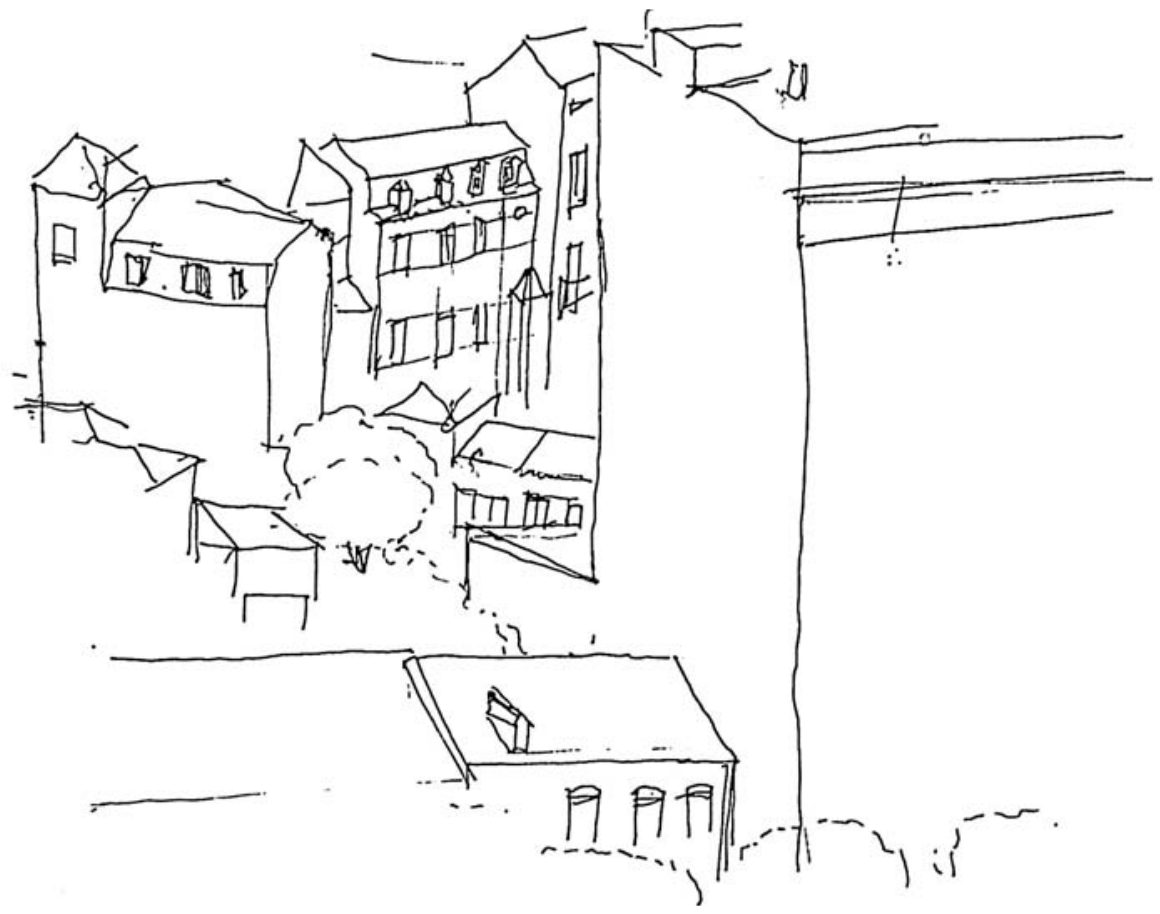

Helder Ferreira
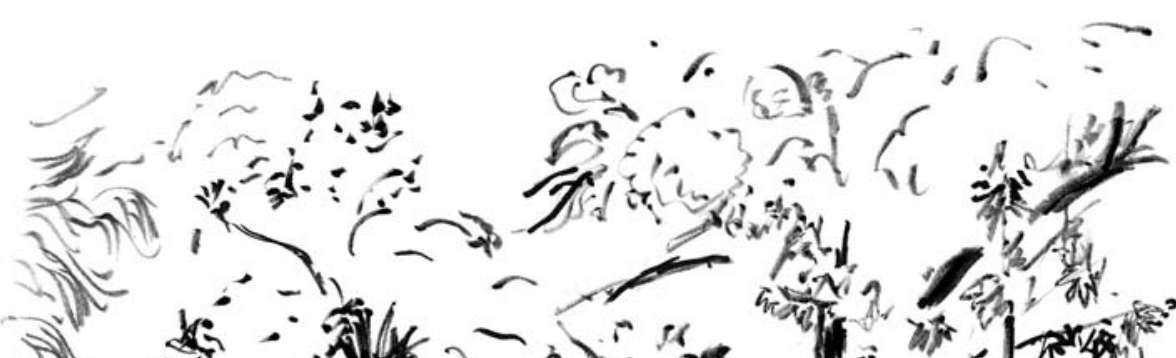

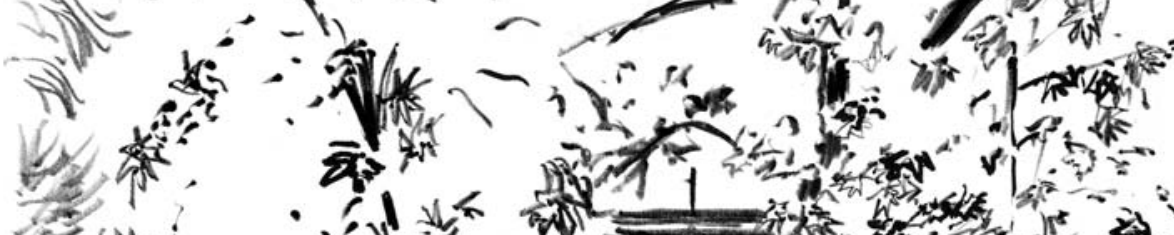

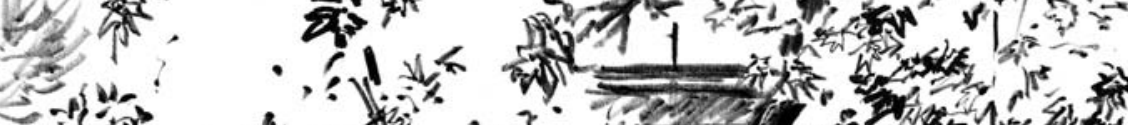

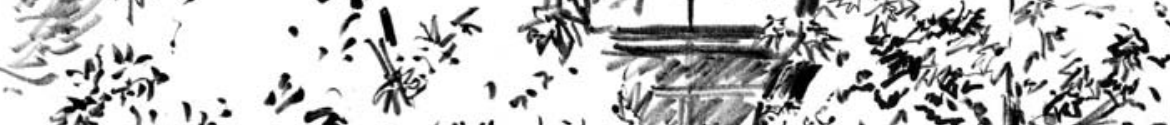

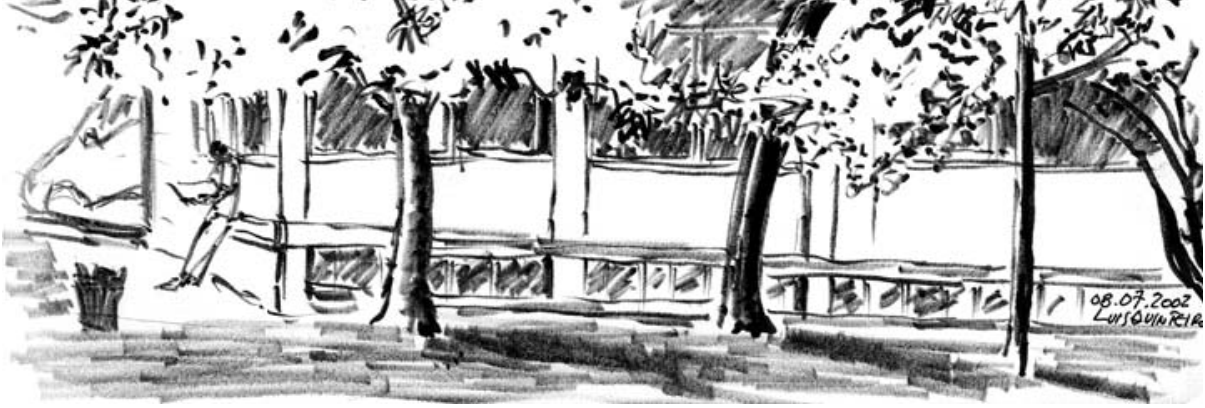



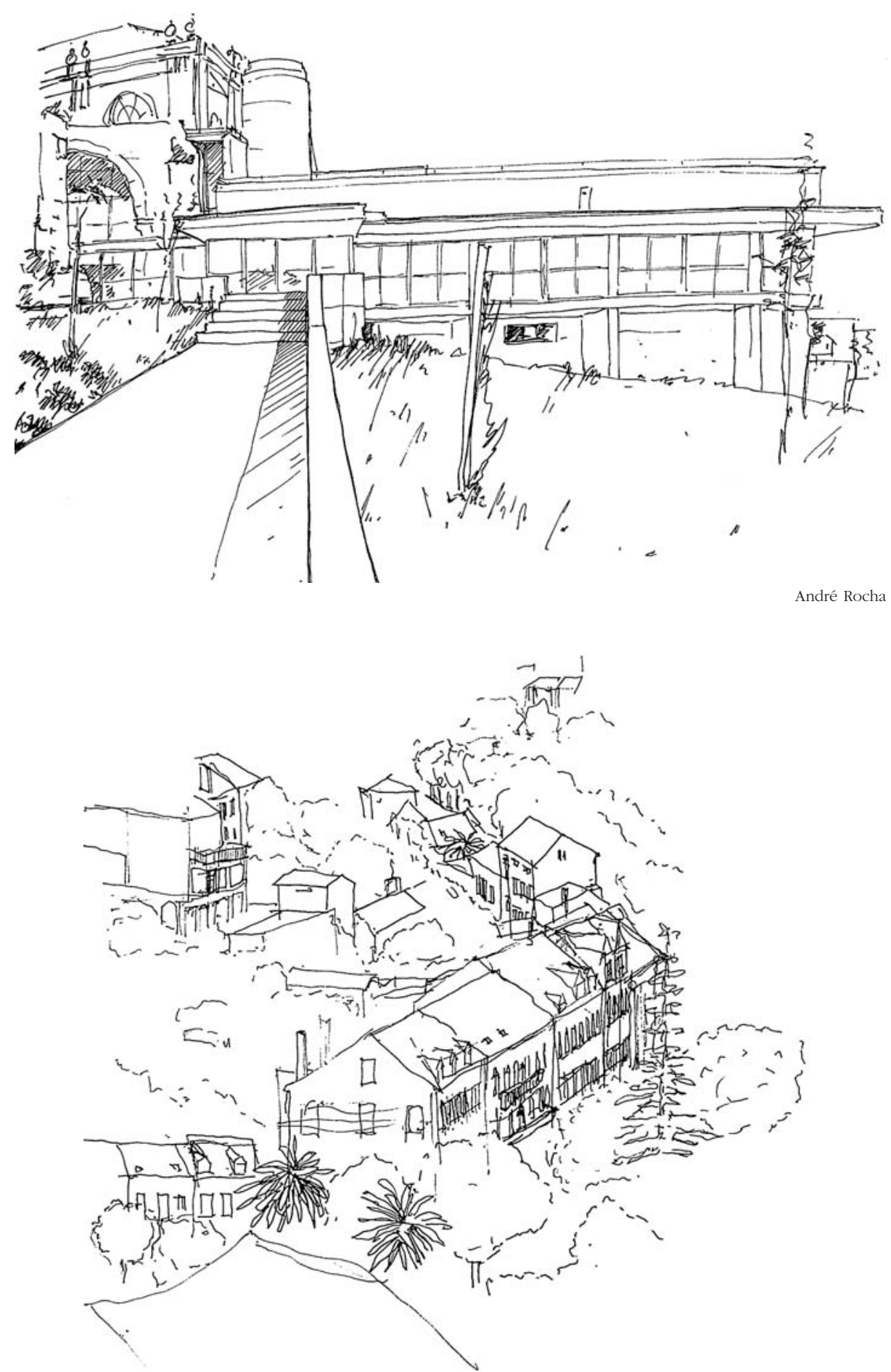


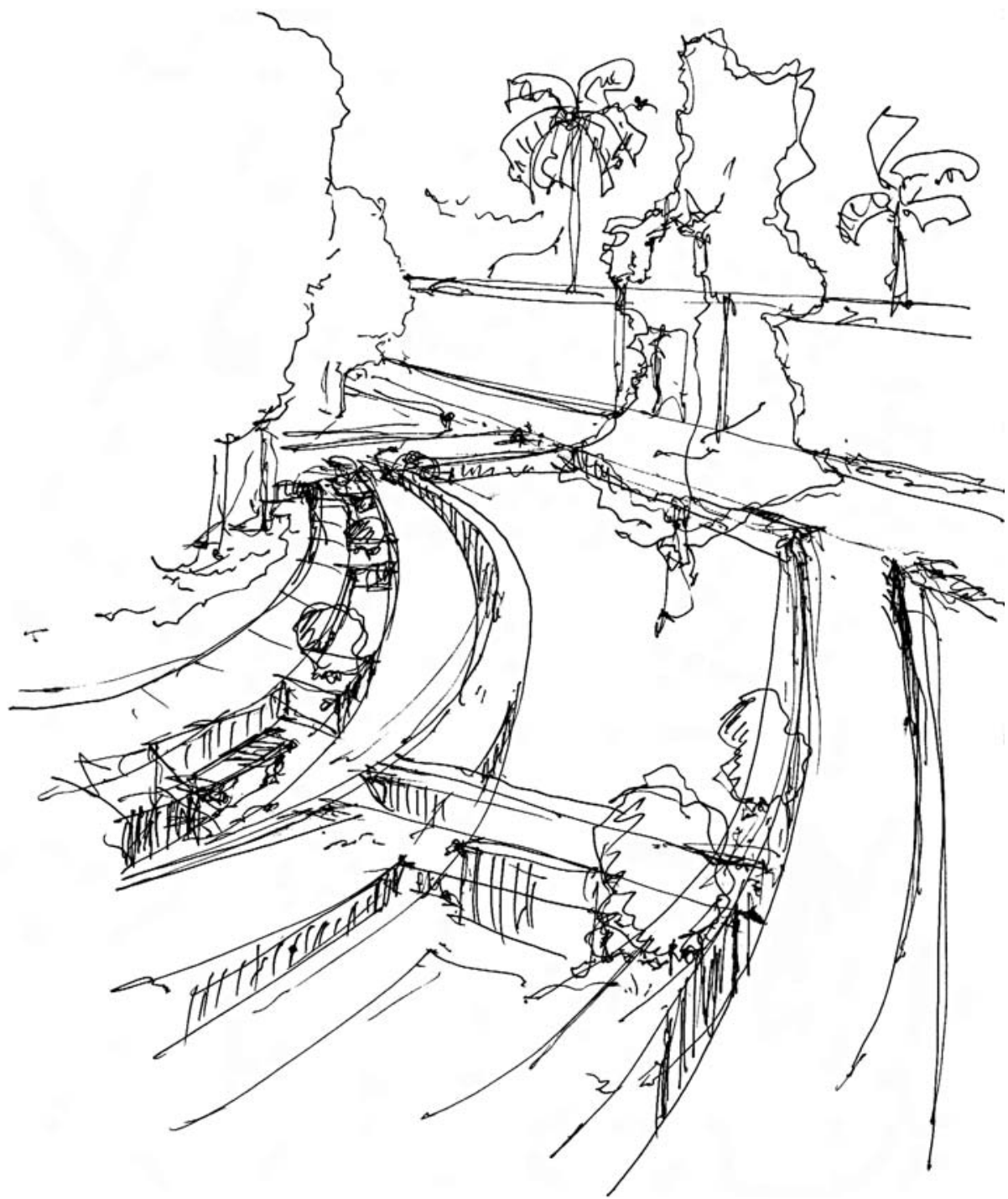




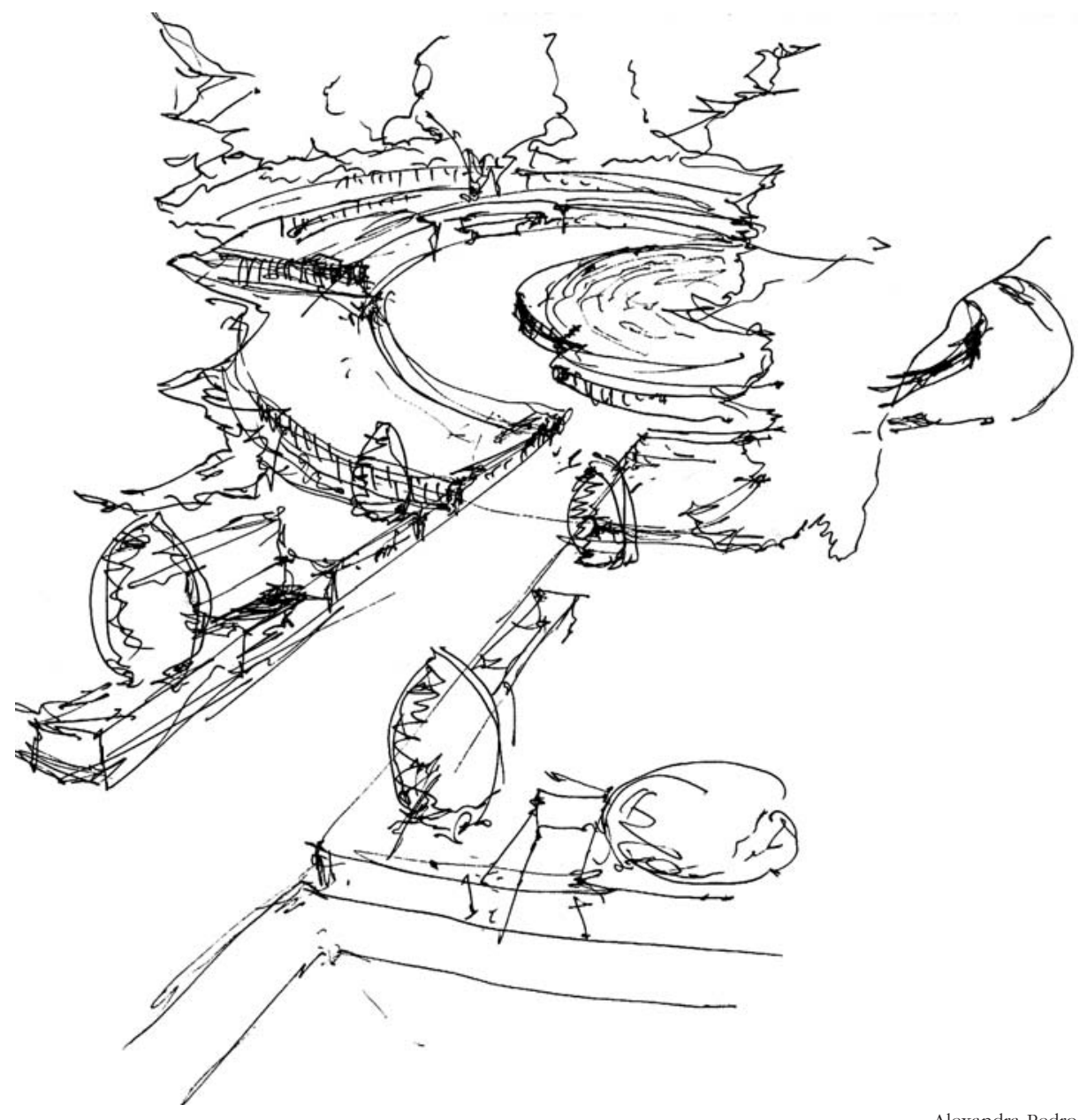


Perante a complexidade da paisagem urbana o desenho poder ser um precioso instrumento de síntese.

E, mais do que percepcionar a realidade como somatório de objectos, pelo desenho podem-se tornar visíveis as linhas de força que estruturam a paisagem.

Desta forma, como exercício desenvolvimento das capacidades de síntese, os alunos procuram, com o mínimo de linhas, sugerir o que é essencial.

Aproximando-se do limite da invisibilidade, as linhas obtidas, mais do que traduzir a realidade visível, traduzirão uma interpretação estrutural da paisagem.

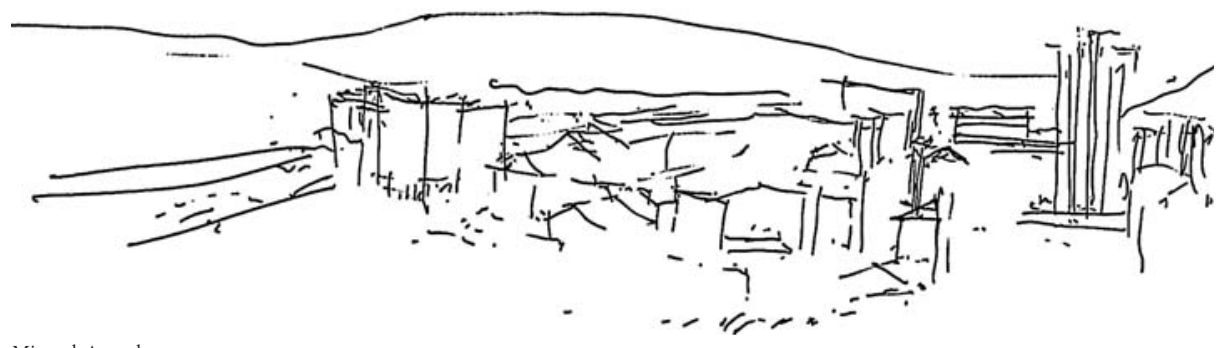

Miguel Amado 


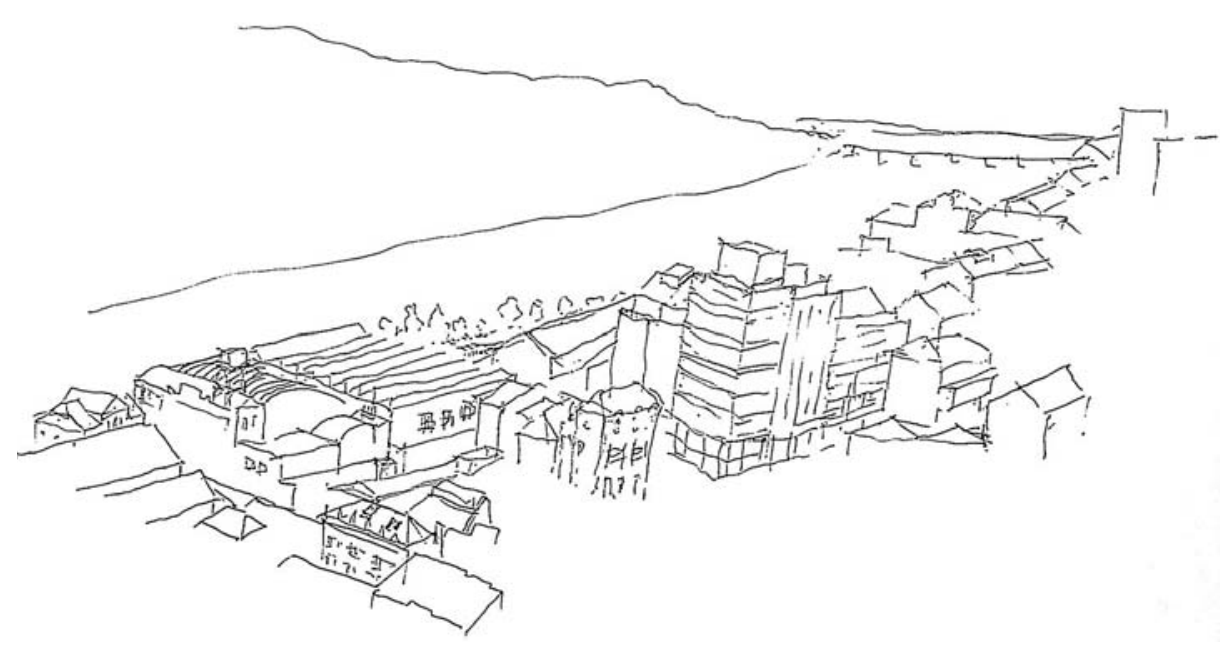

Tiago Rodrigues

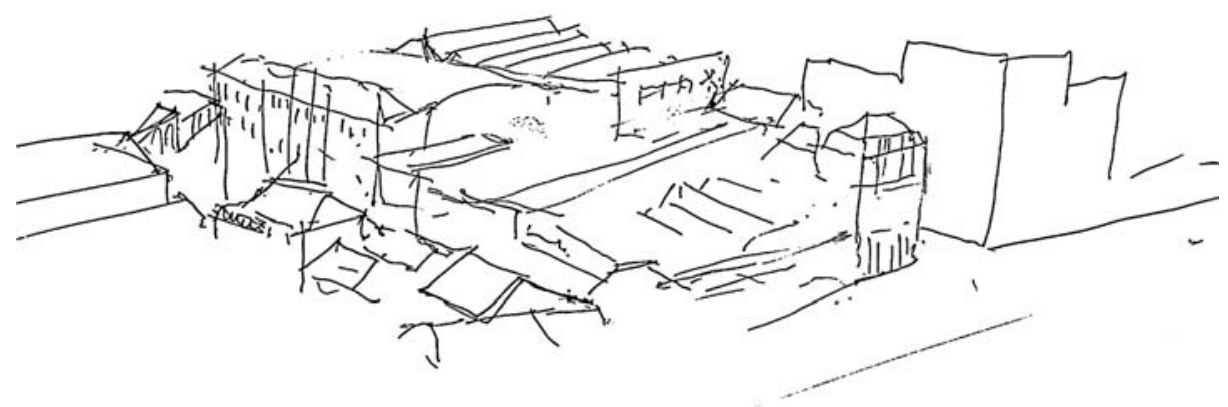

Miguel Amado 
36

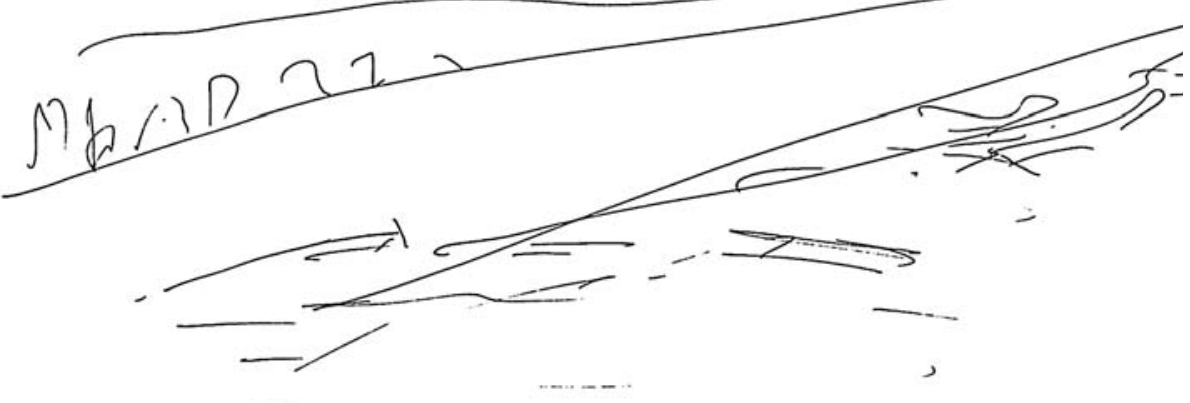

Paulo Luís
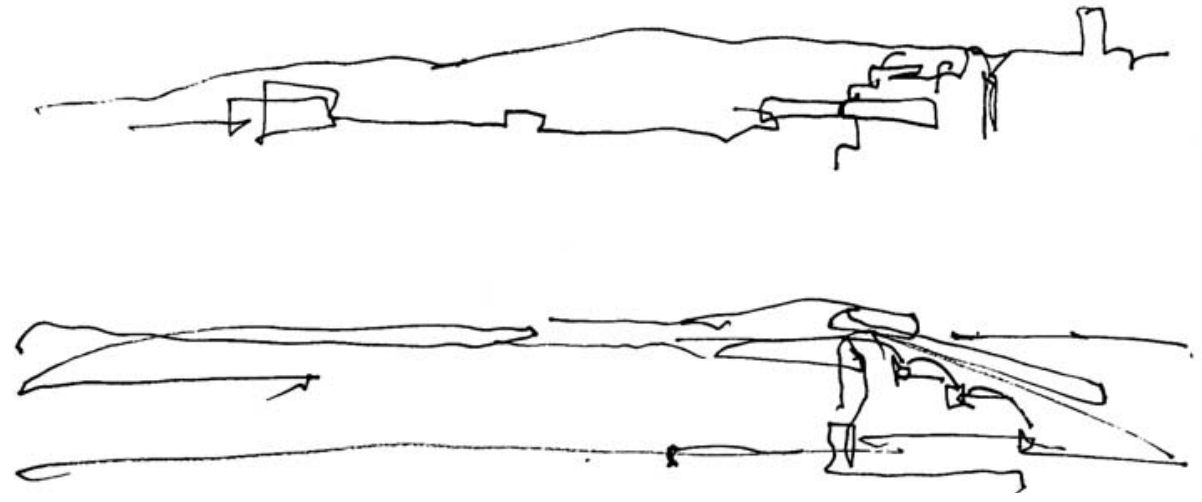

Maria Henriques 


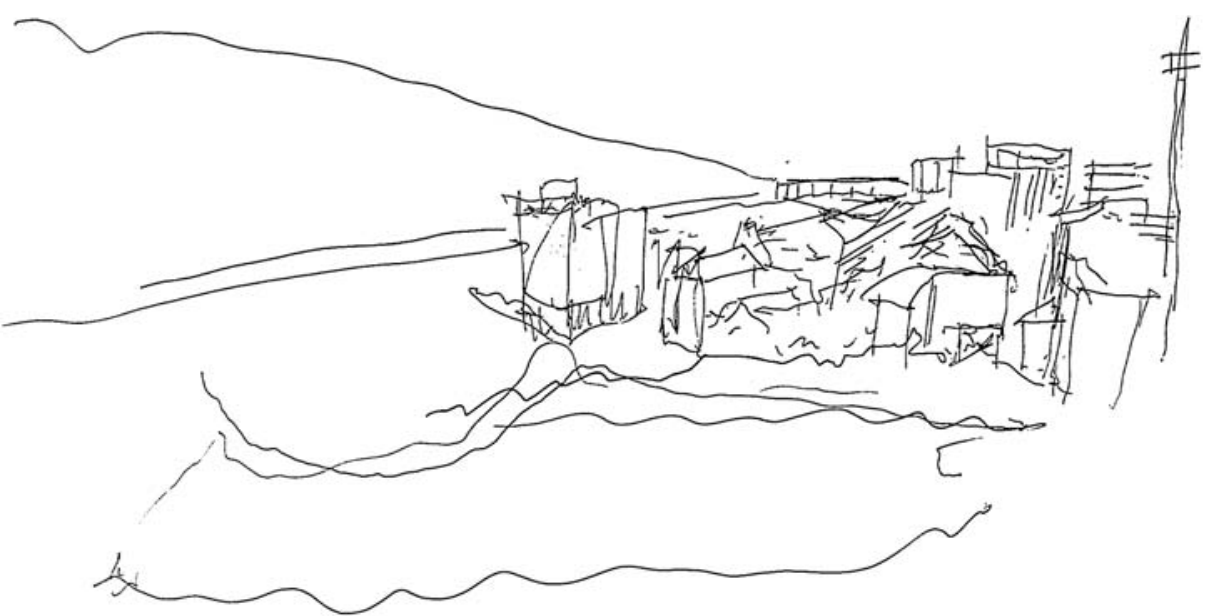

Miguel Amado

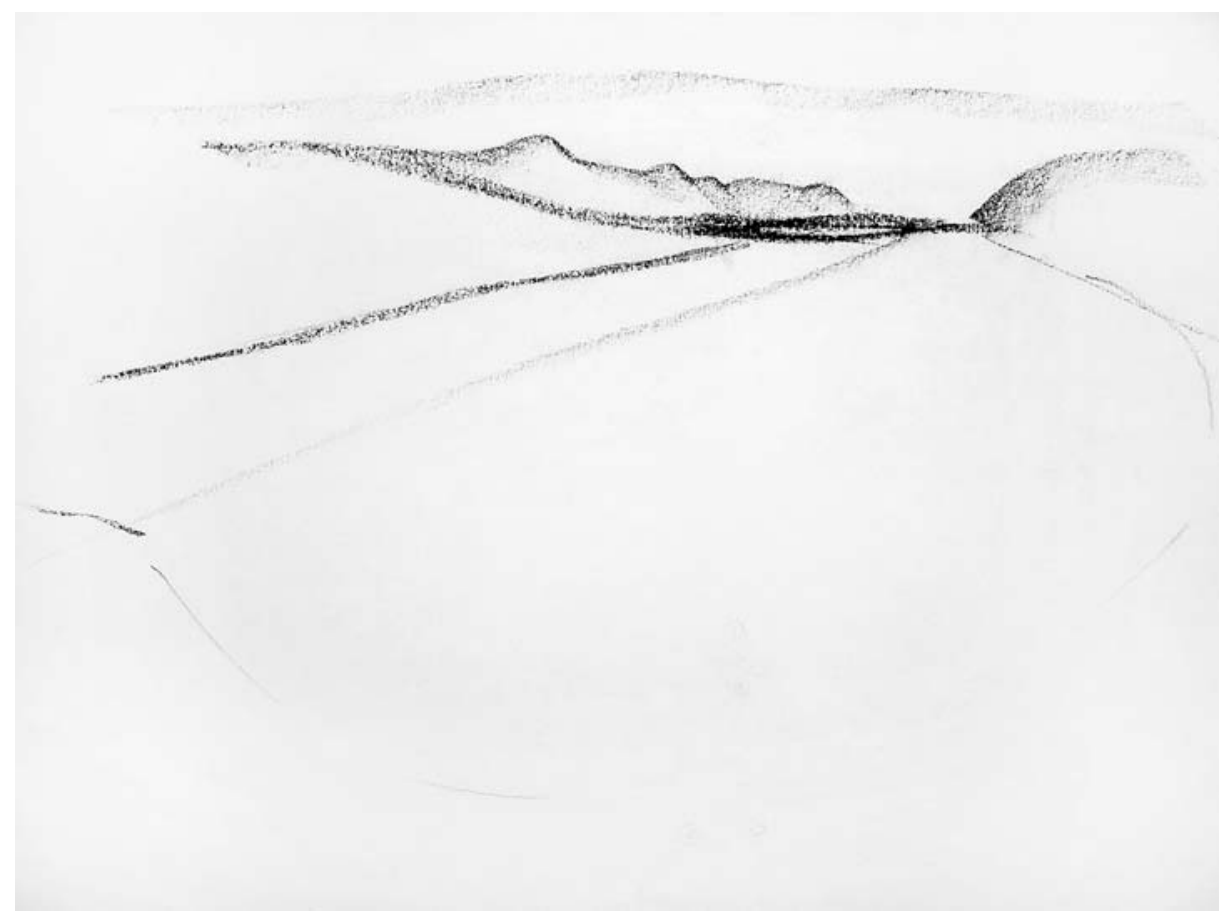

Tiago Rodrigues 


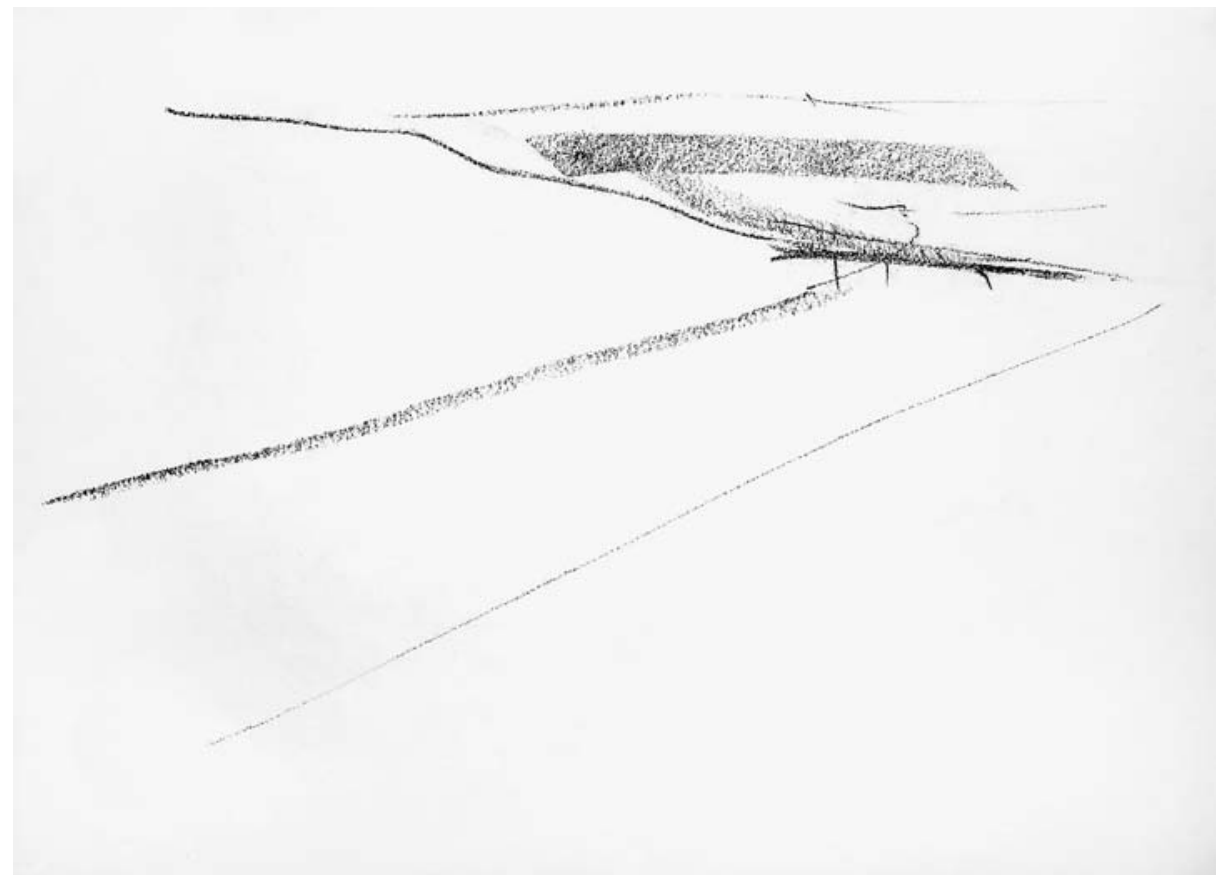

Tiago Rodrigues

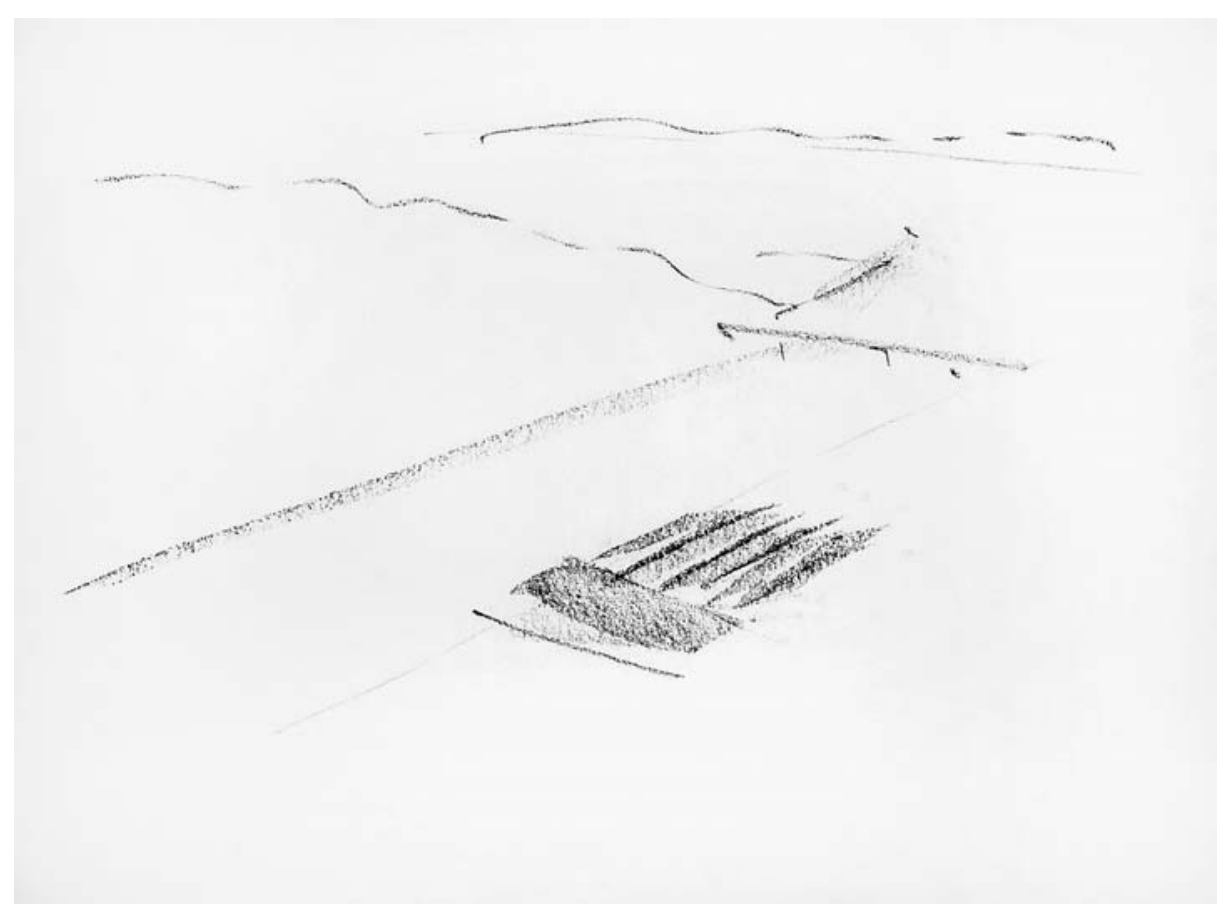




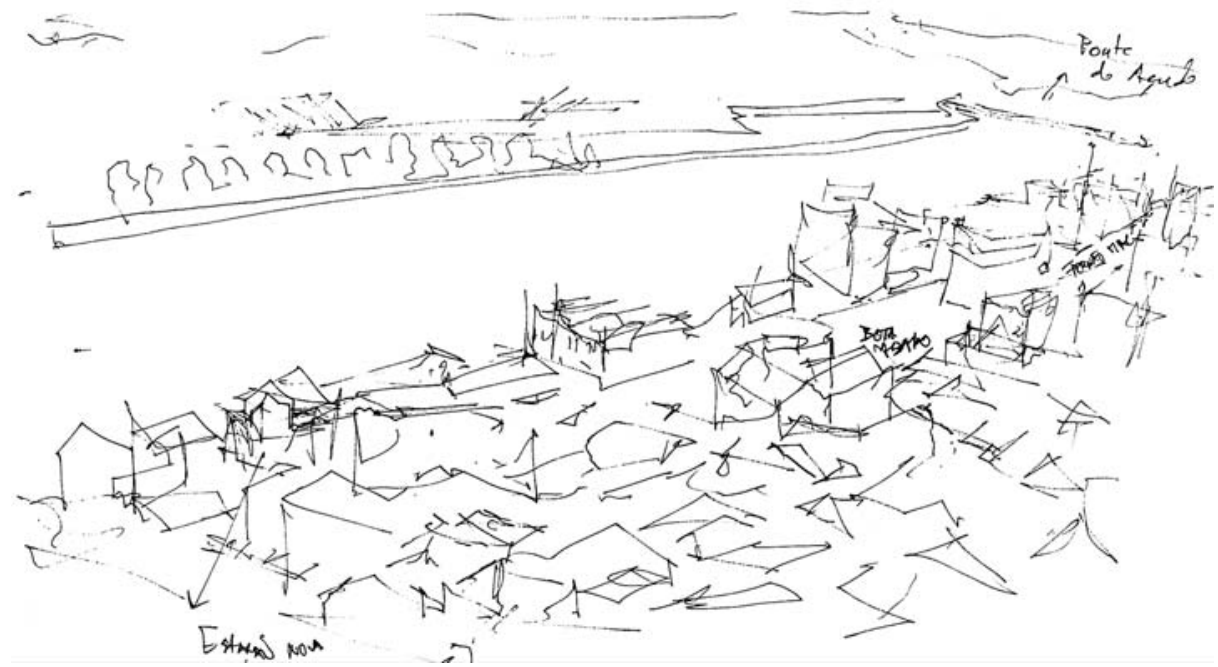

Inês Dantas

$\mathrm{Na}$ consciência da autonomia do desenho como linguagem, as linhas, as formas motivadas pela representação podem ser exploradas na sua autonomia gráfica e compositiva.

Assim, no desenho, os alunos criam uma nova realidade que, tendo origem na realidade visível, cria o seu próprio universo.

Pelo enquadramento, pela acentuação ou síntese das linhas e das formas, o desenho é aqui revelado nas suas potencialidades plásticas.

Mais do que conduzido pela semelhança, ou pela sua qualidade documental, o desenho é espaço para desenvolvimento da sensibilidade compositiva.

Nascendo da representação, e conduzidos por ela, estes desenhos procuram na realidade sobretudo motivações formais. 


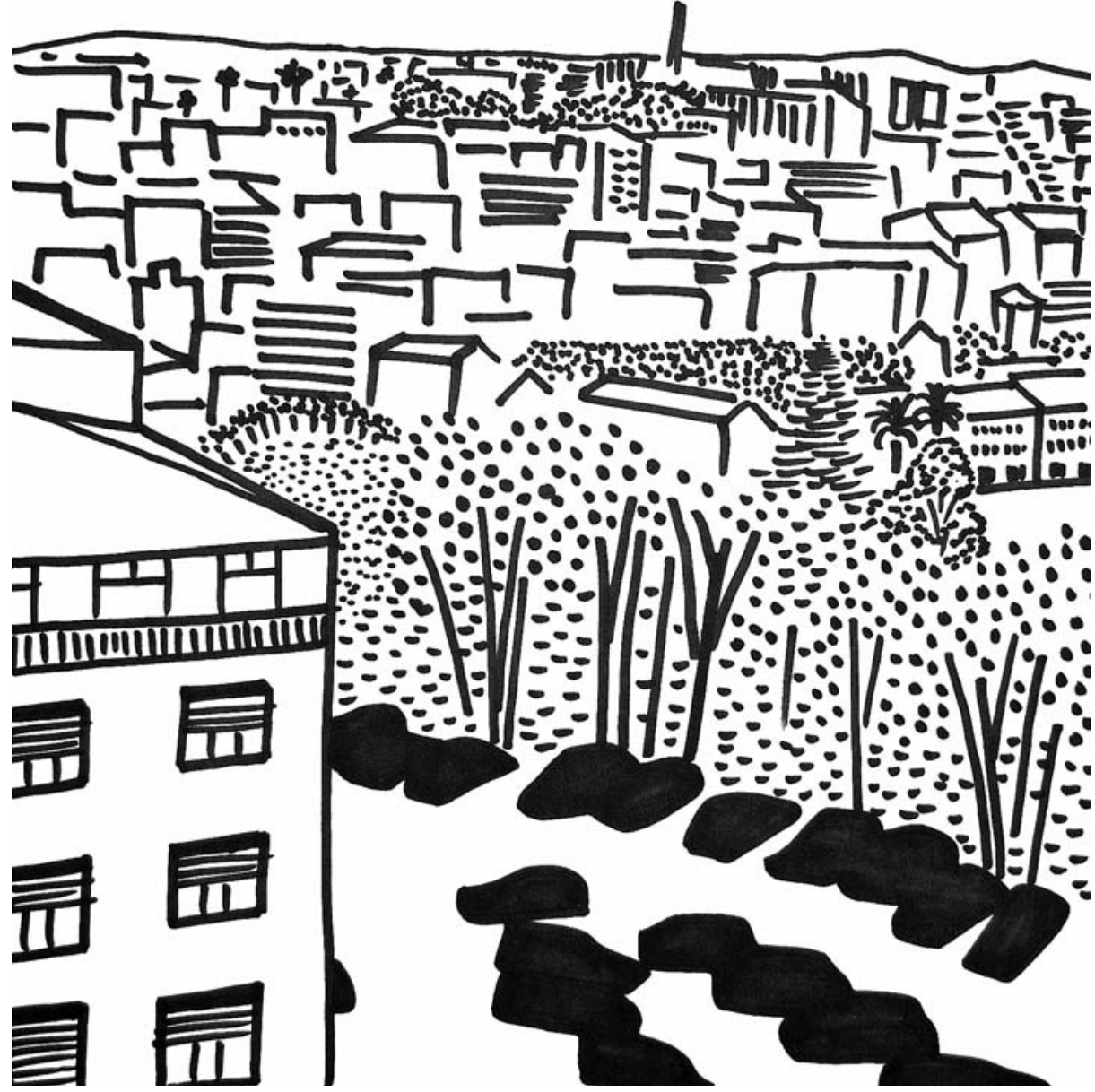




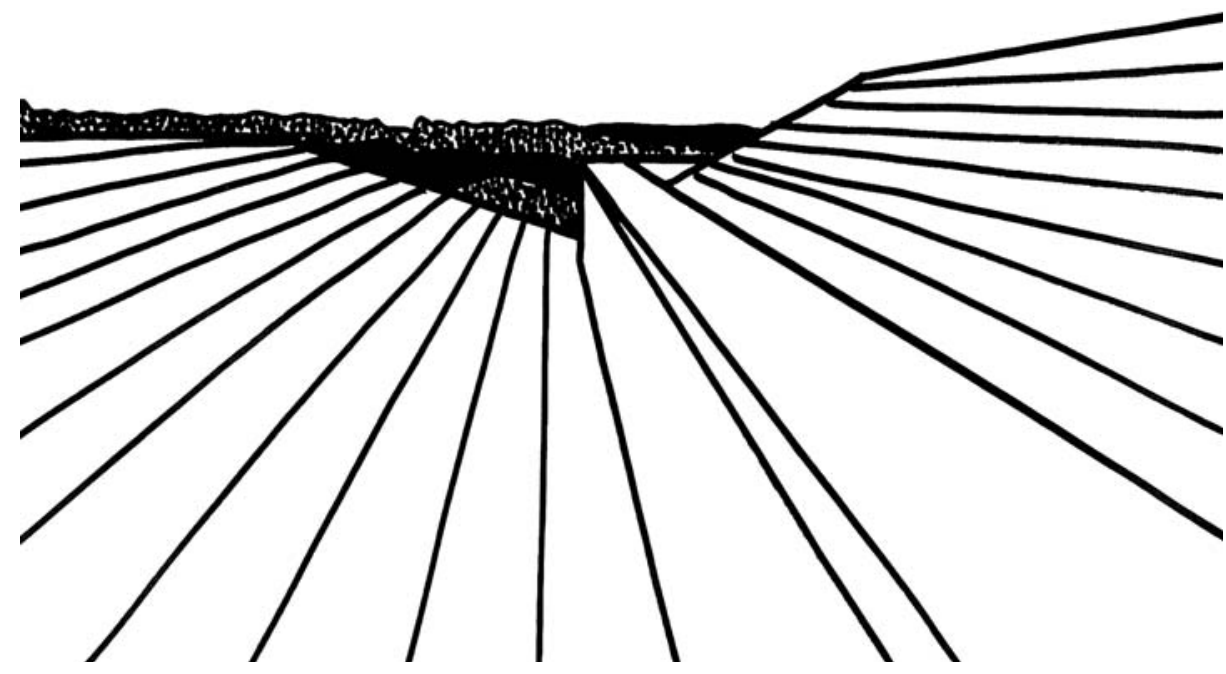

Hugo Santos

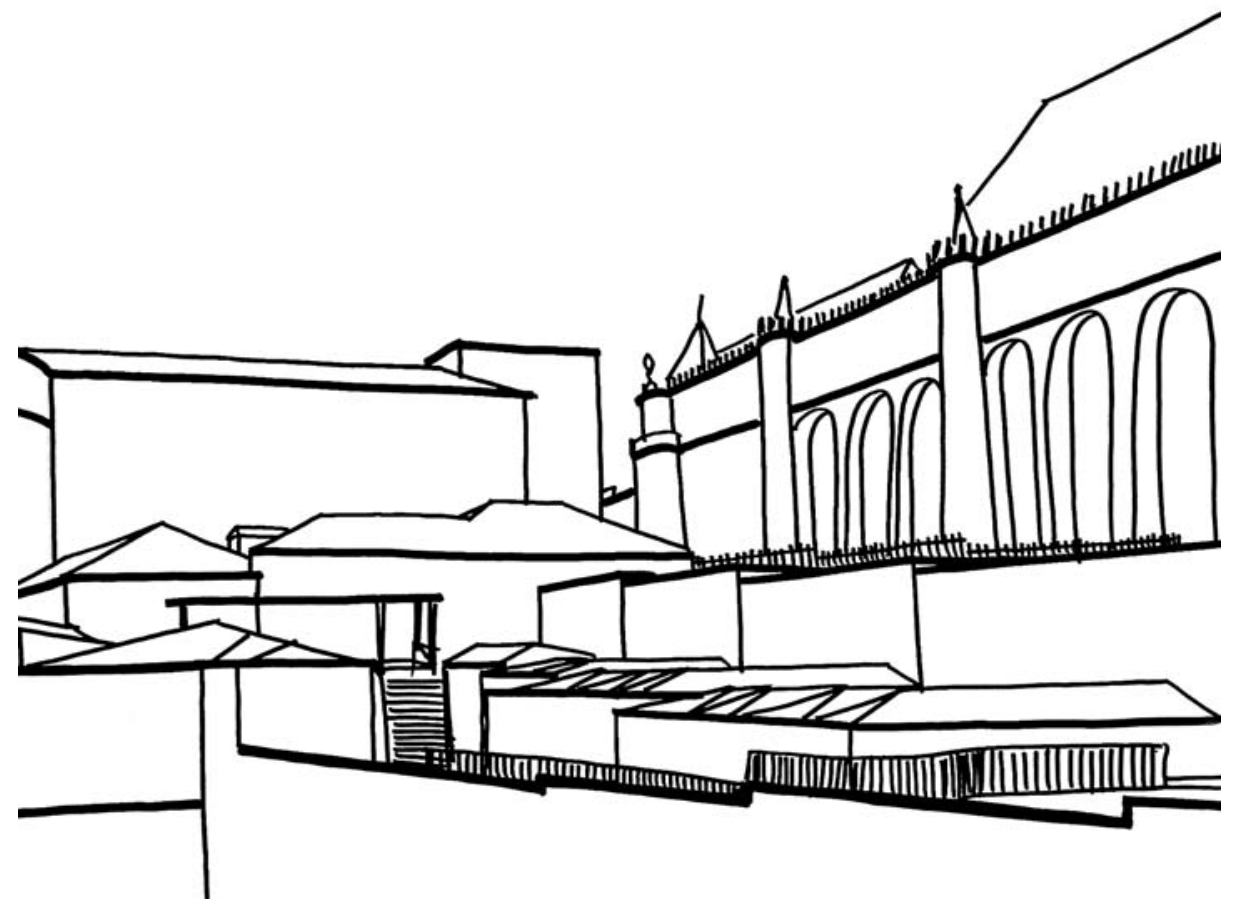




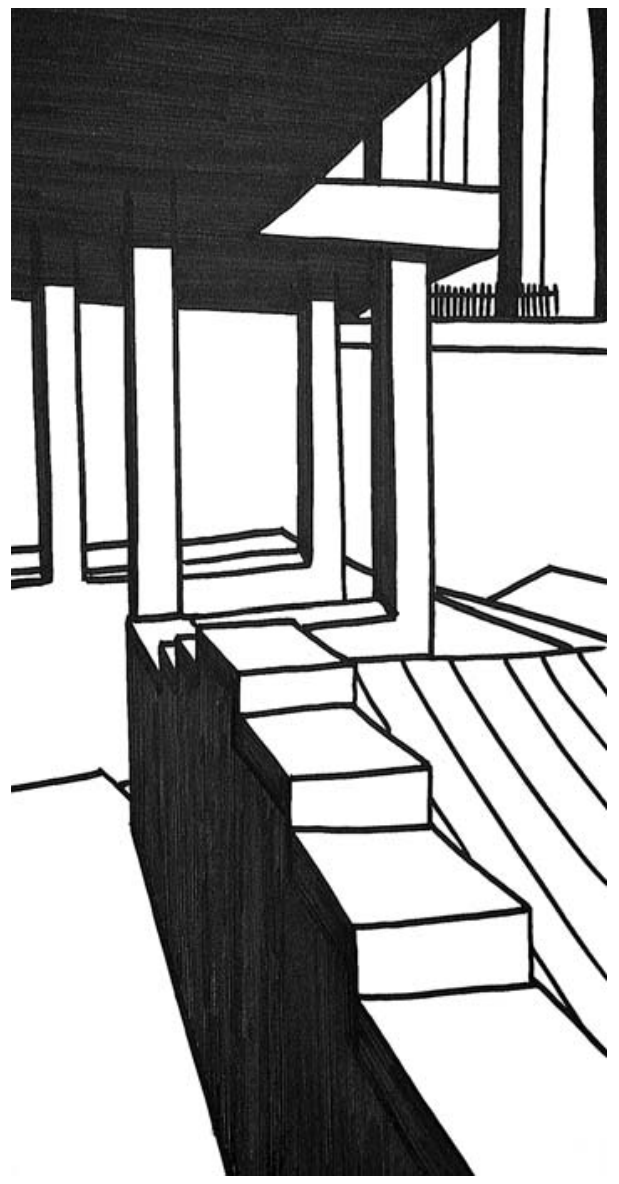

Hugo Santos

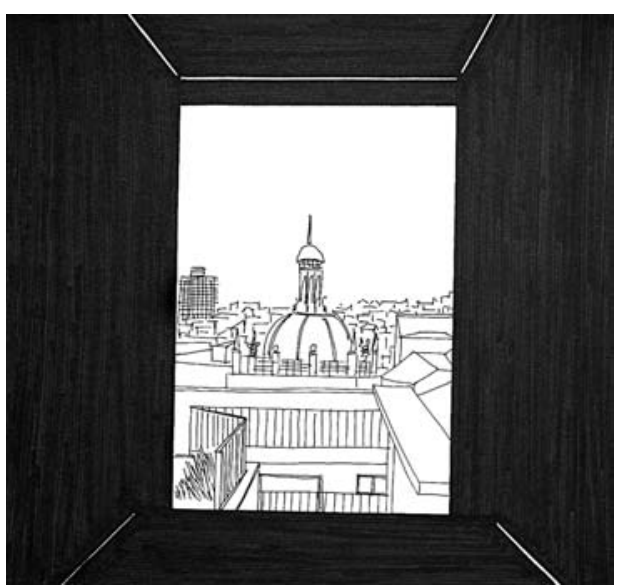

Hugo Santos 

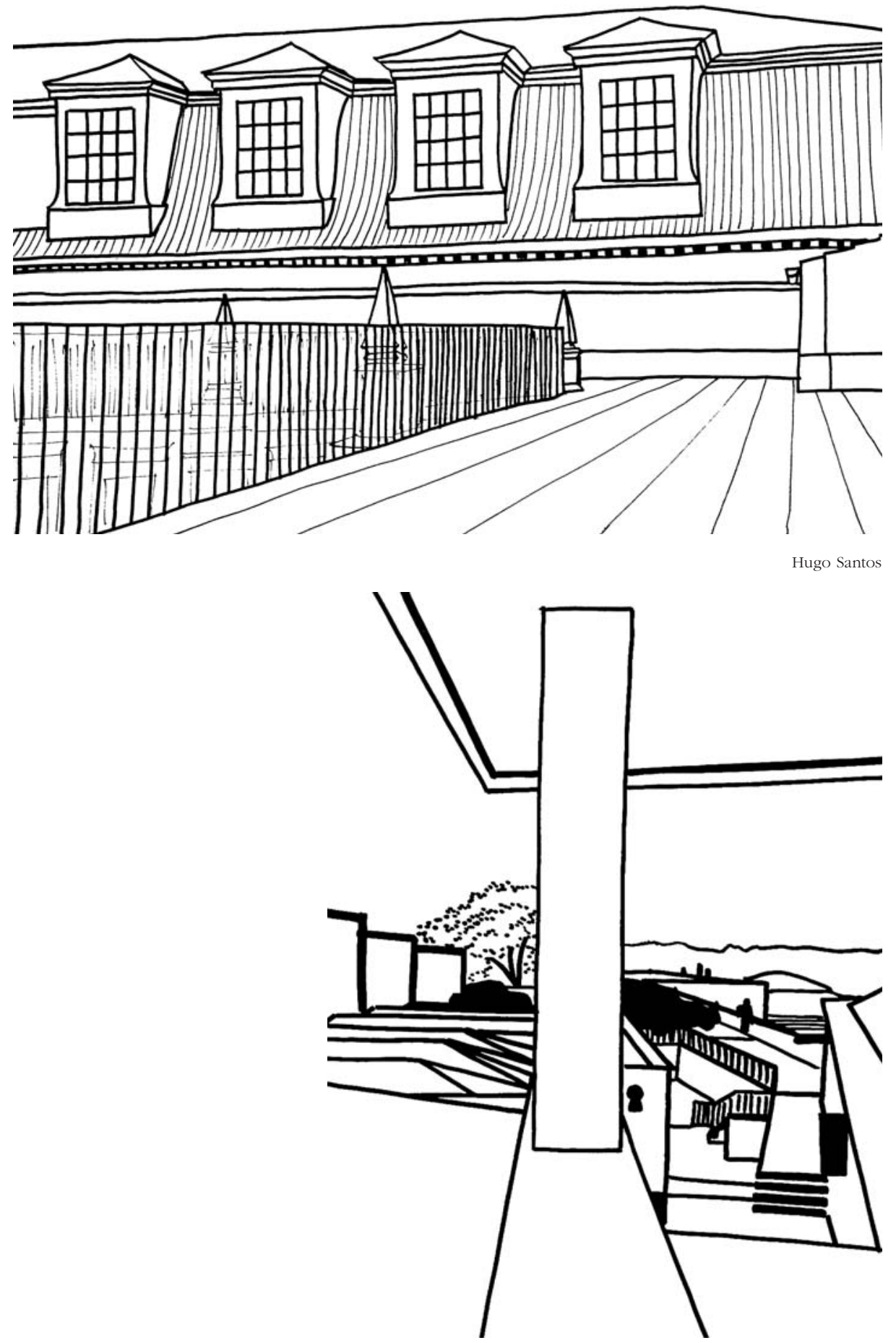

Hugo Santos 


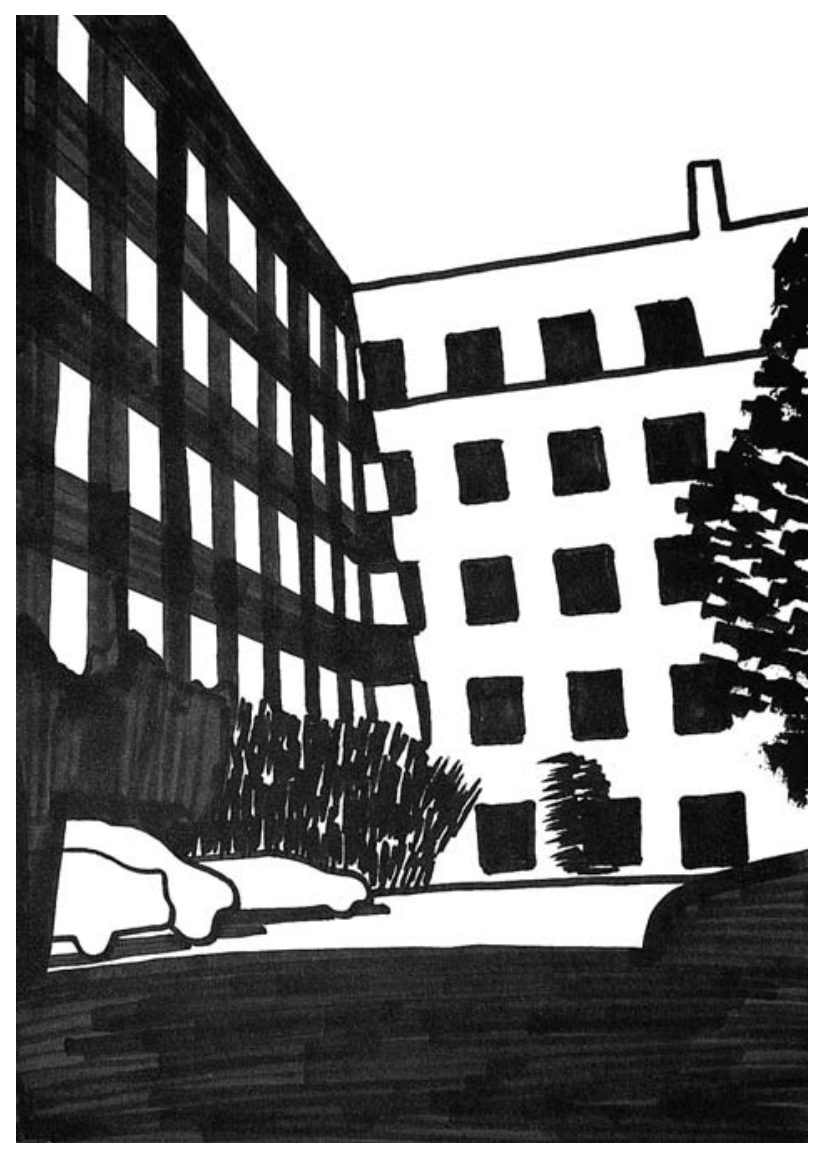

Hugo Santos

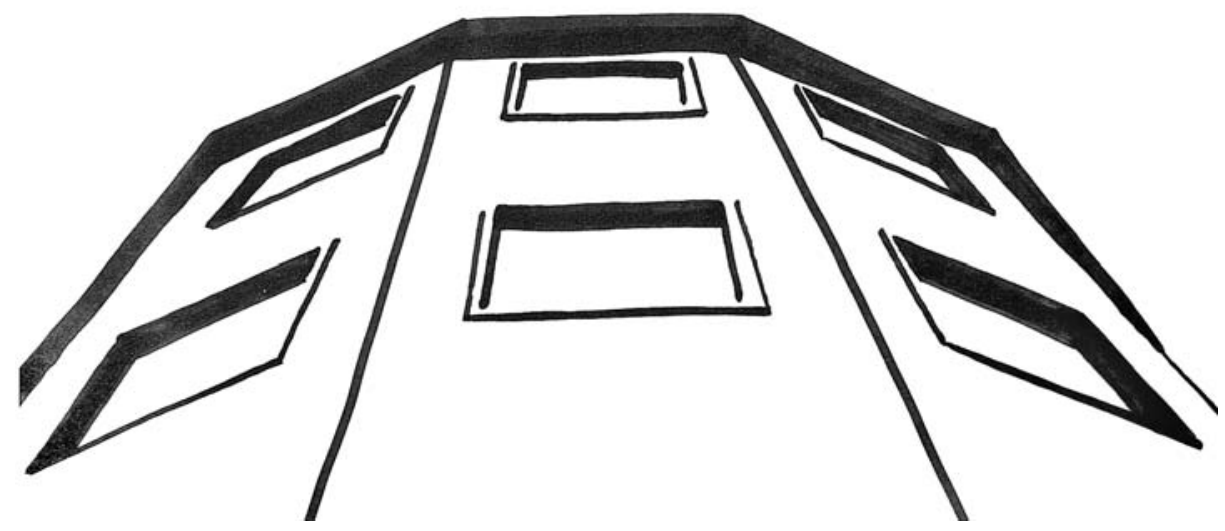

Hugo Santos 

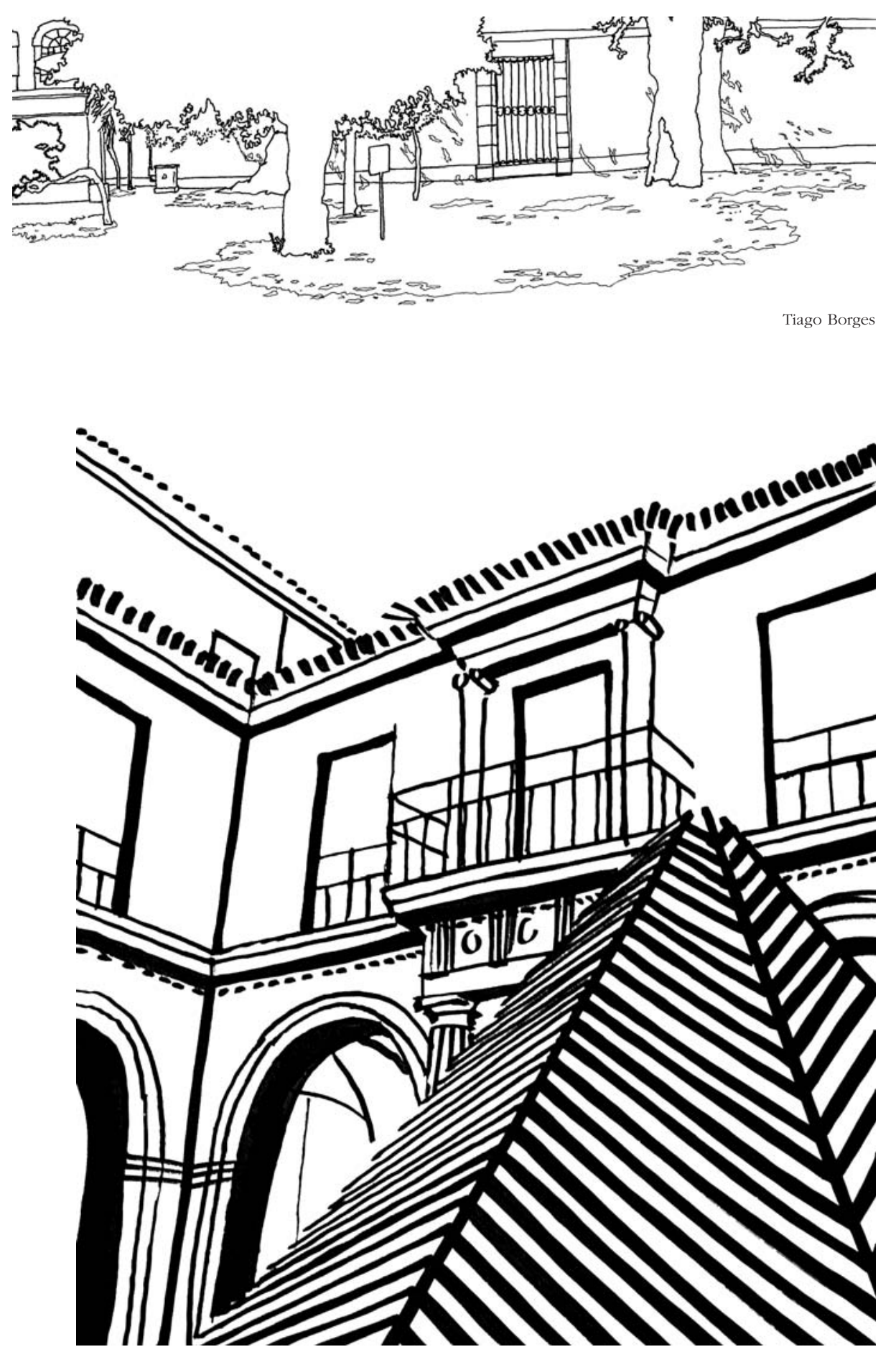


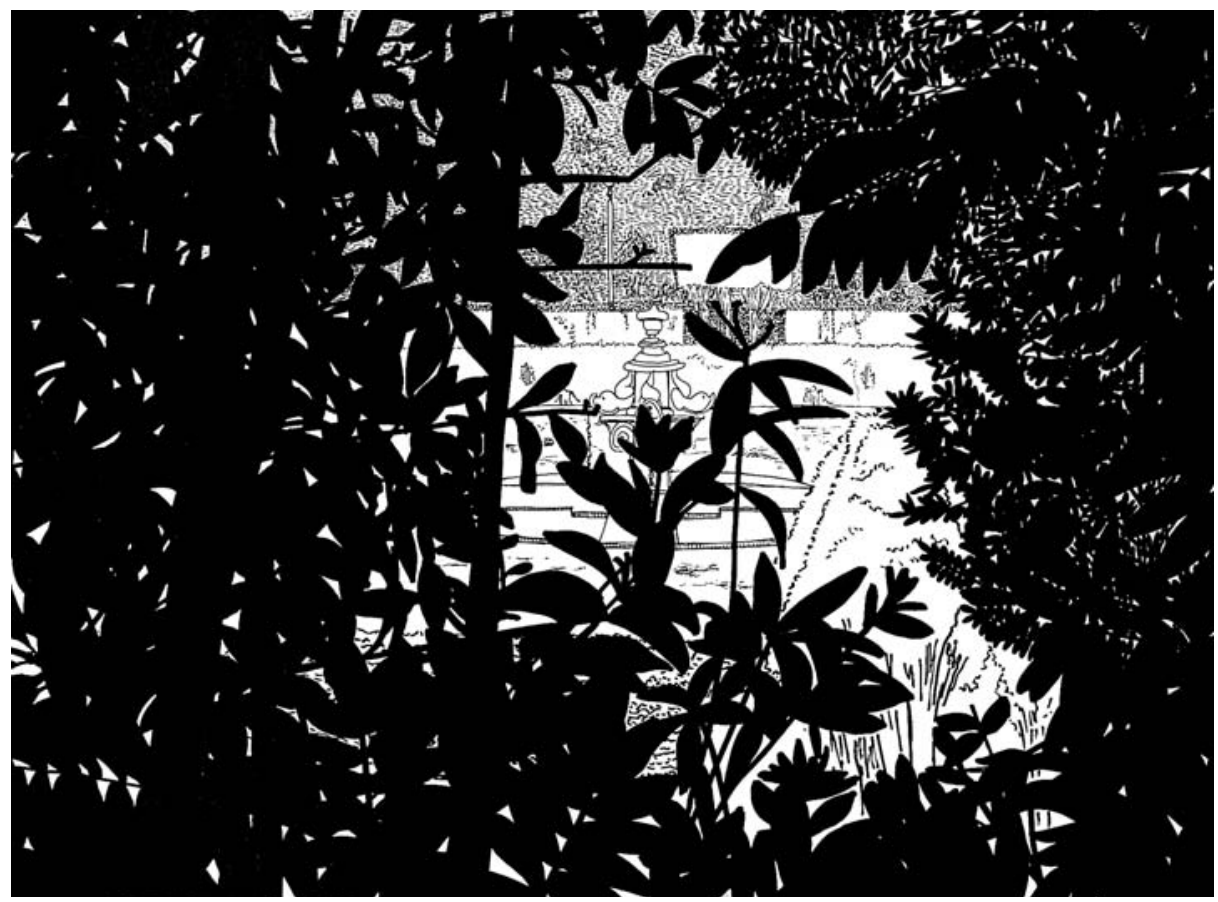

Hugo Santos

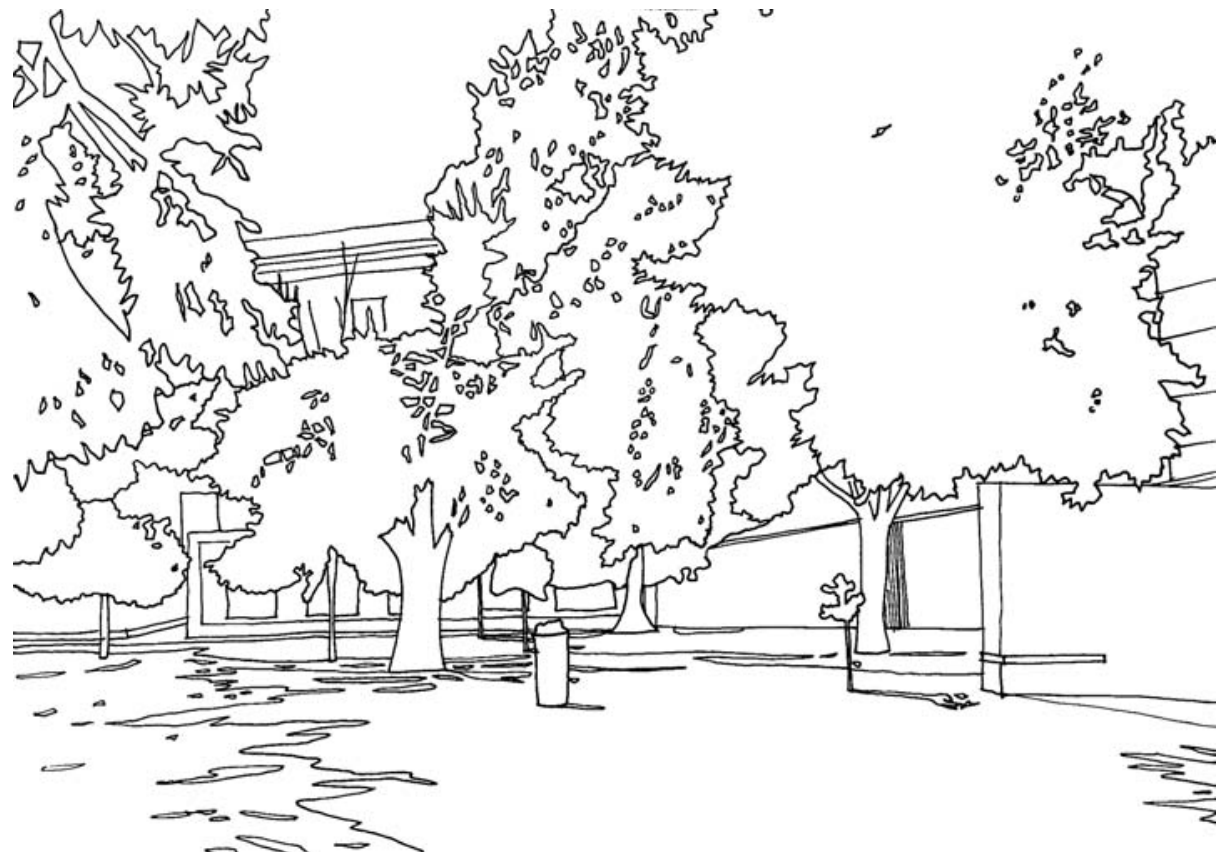

Hugo Santos 


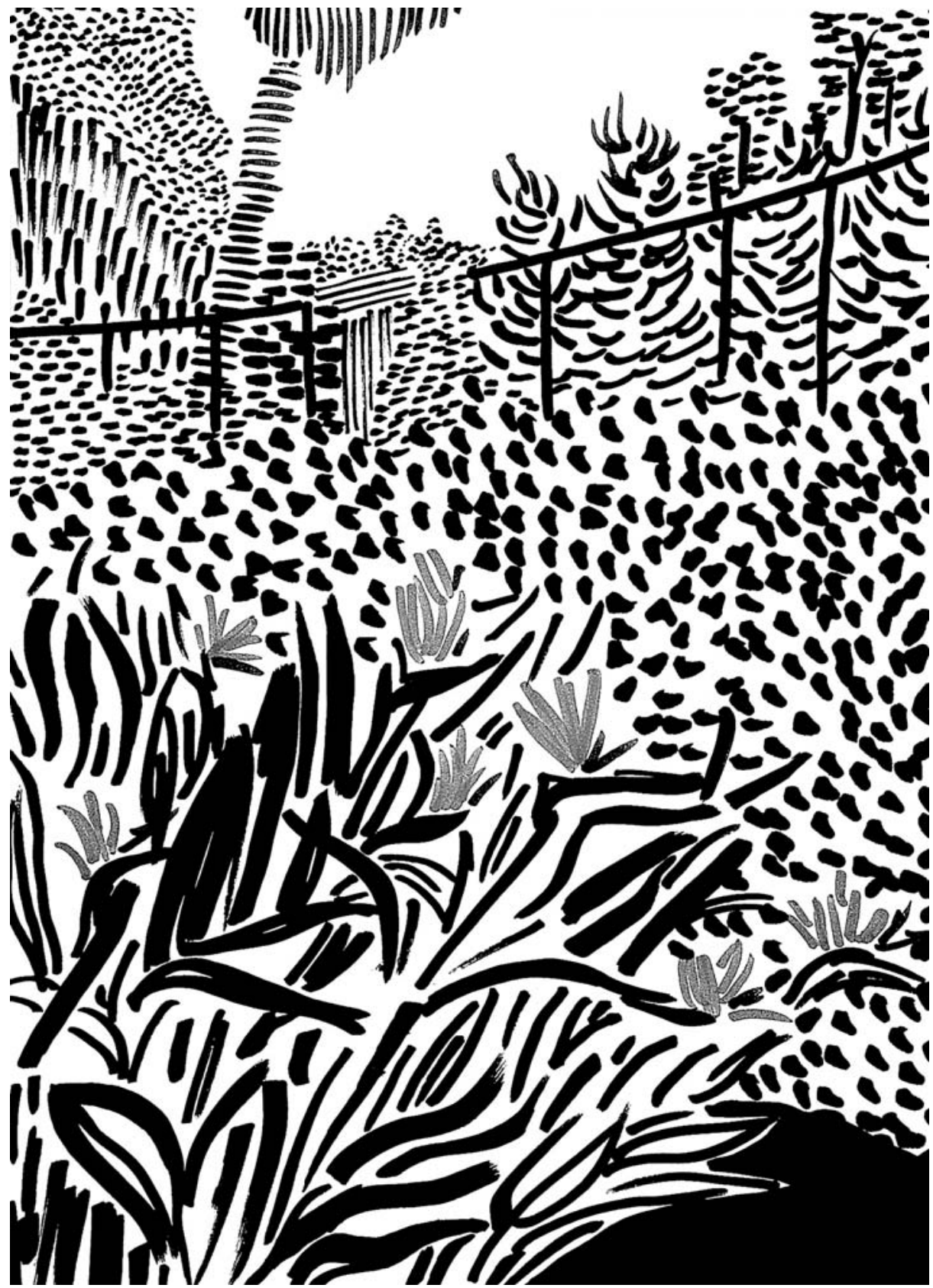




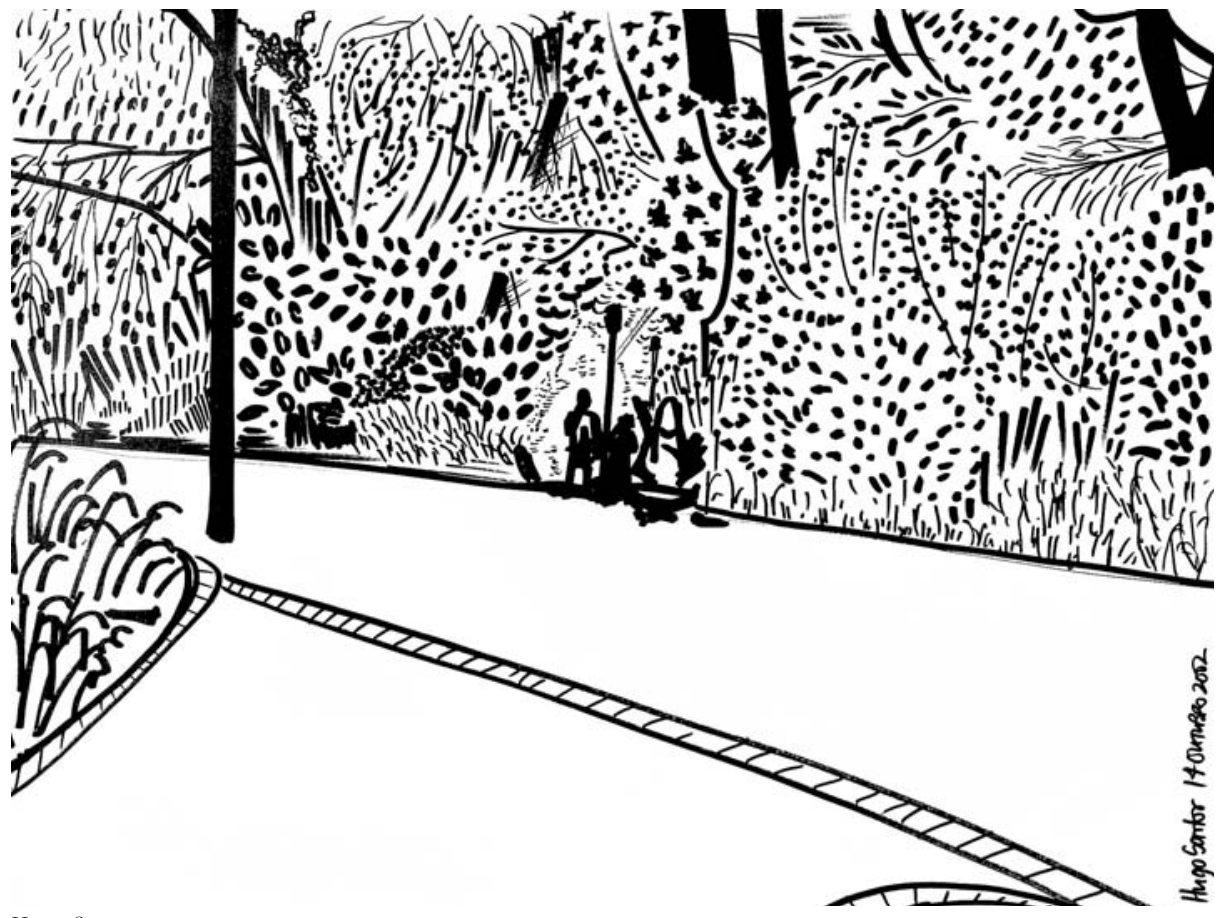

Hugo Santos

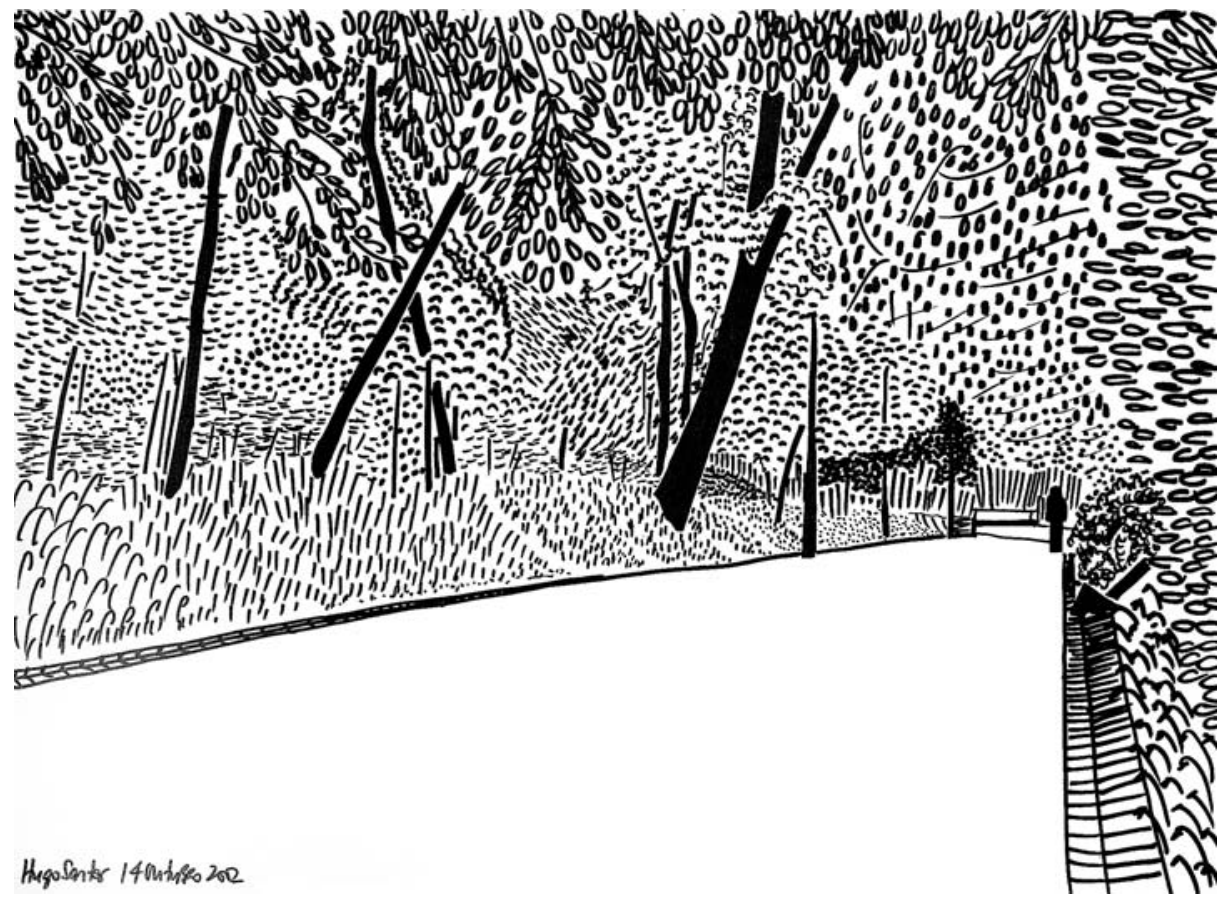




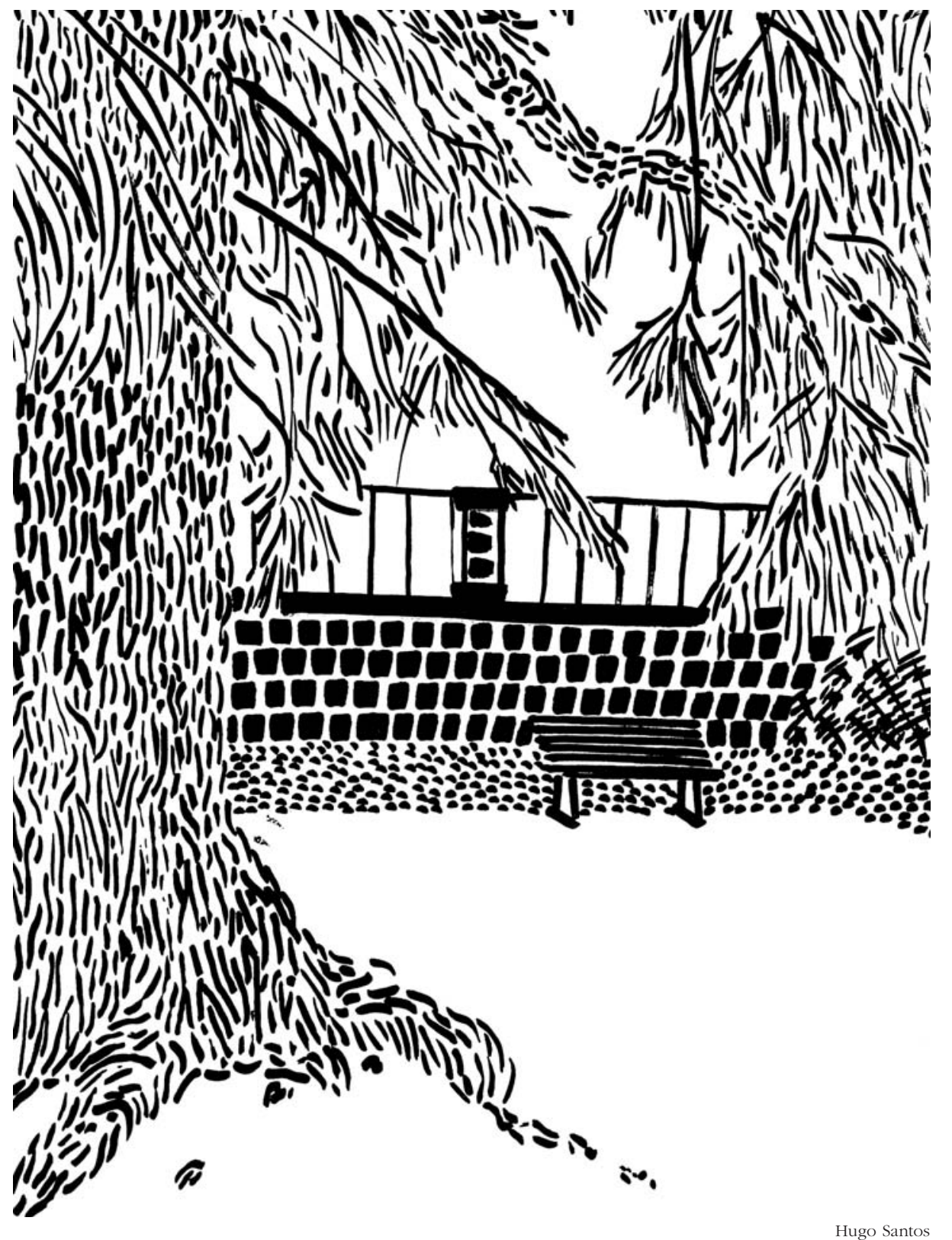




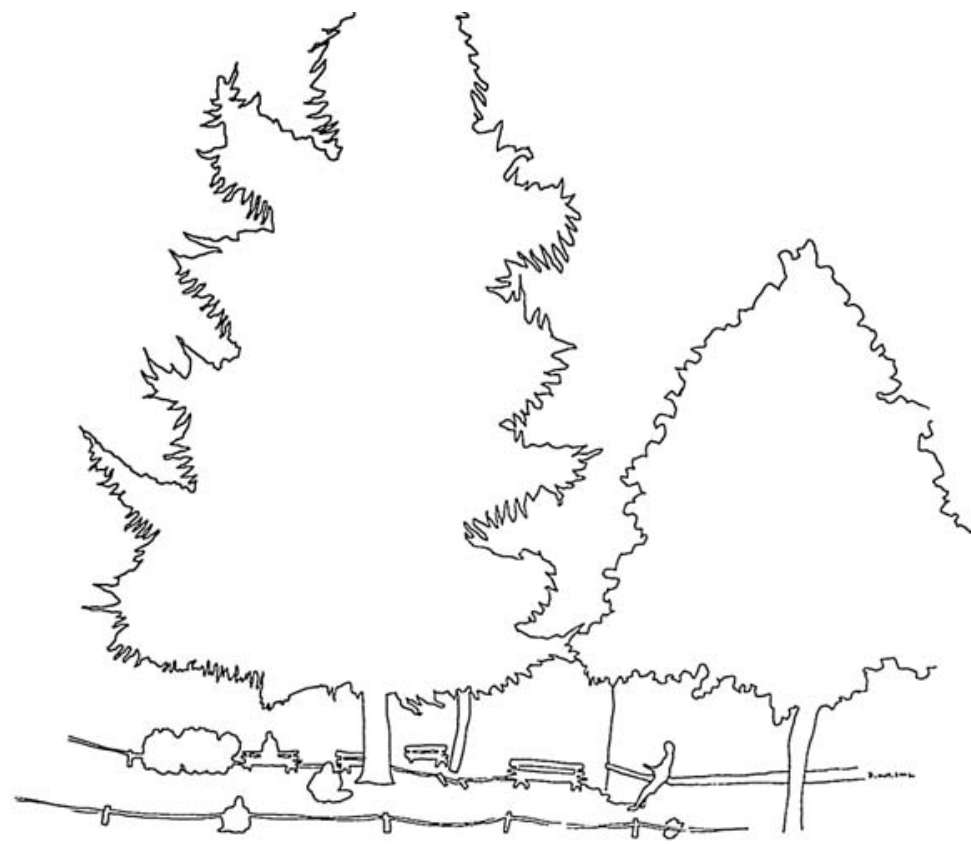

Tiago Borges

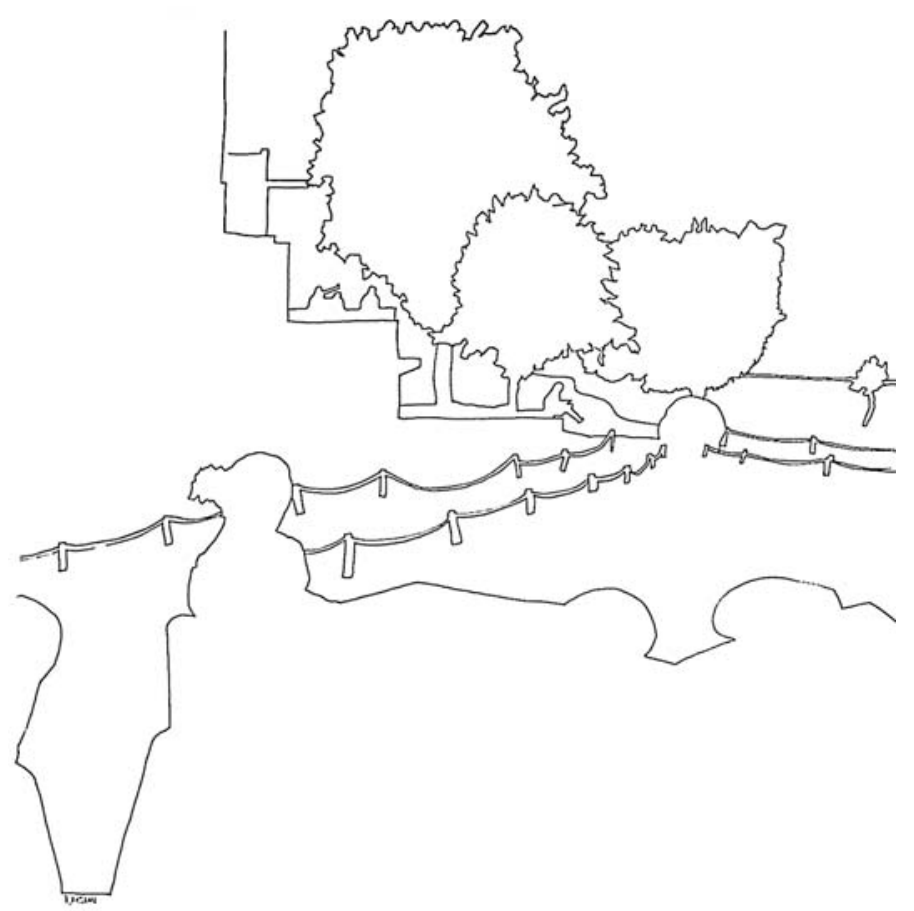




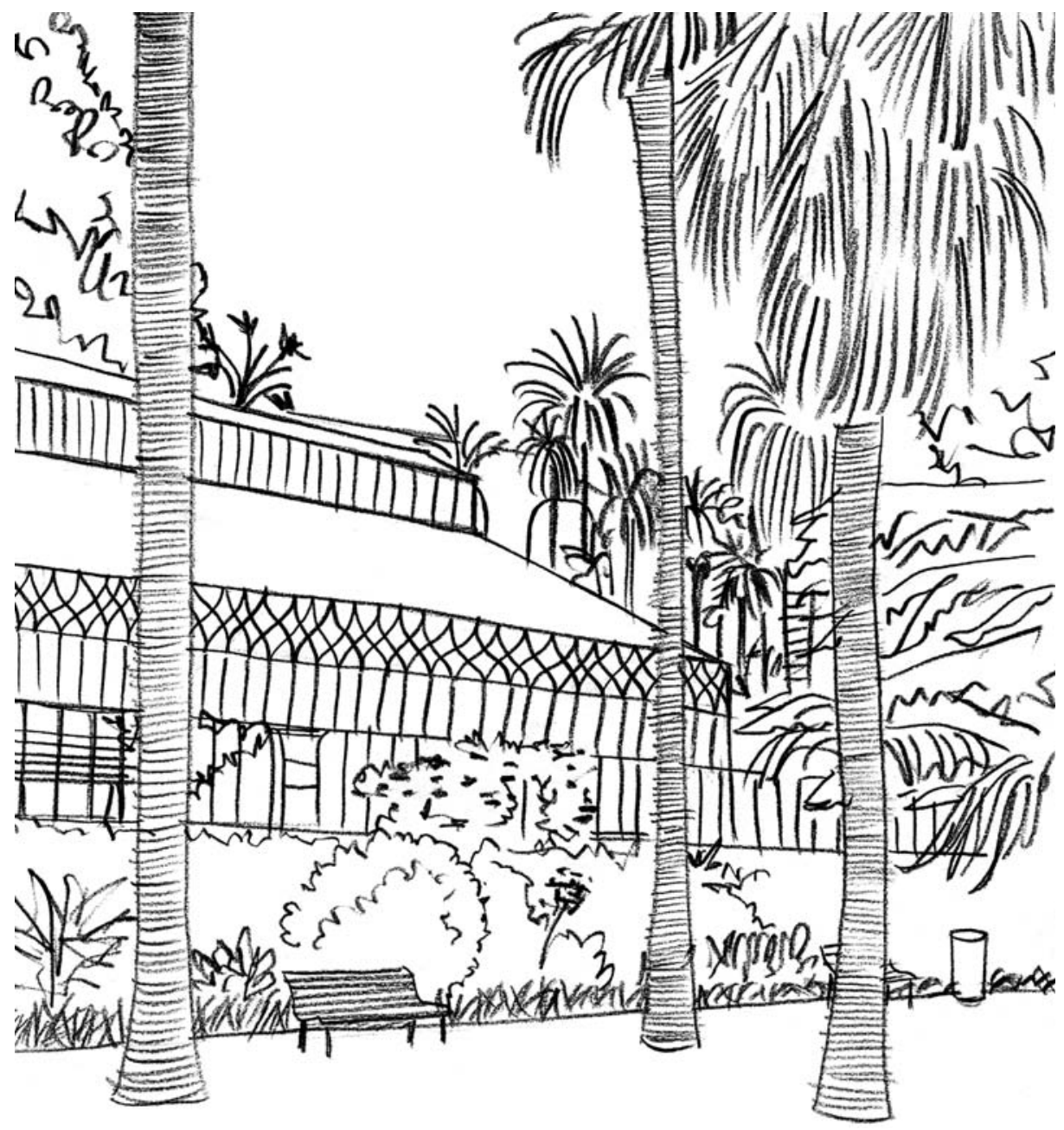


(Página deixada propositadamente em branco) 


\section{EXPERIÊNCIAS CALIGRÁFICAS}

A PARTIR DA REPRESENTAÇÃO DA MÃO 
(Página deixada propositadamente em branco) 
Nestes exercícios, as sucessivas representações da mão, serão, sobretudo, a procura de aquisição de um mais vasto léxico gráfico, potenciador de uma maior flexibilidade de resposta a diferentes situações.

Sendo o modelo ponto de partida, constante, e sendo, sobretudo, a caligrafia que muda de desenho para desenho, mais do que a representação, aqui se sublinham as especificidades do desenho enquanto linguagem.

$\mathrm{Na}$ multiplicidade de soluções gráficas para a representação de um mesmo modelo, nestes exercícios gera-se a noção de que o desenho nunca será um mero processo de representação e de que cada opção caligráfica gerará realidades diferentes.

As diferentes caligrafias serão encontradas na relação entre a intencionalidade e a mecânica do gesto, procurando-se a uma clareza, não saturando um mesmo desenho com diferentes situações gráficas.

E, na relação entre o mental e os factores físicos, mecânicos do desenho, explorar diferentes factores condicionantes da caligrafia:

- Velocidade do gesto.

- Gestos rápidos e a maior fluência da linha, vencendo o atrito do suporte

- Gestos lentos e o efeito do atrito no suporte

- Maior ou menor pressão sobre o suporte

- Maior ou menor continuidade ou descontinuidade da linha

- Relação entre linha e mancha

- Exploração das diferentes potencialidades dos instrumentos gráficos 


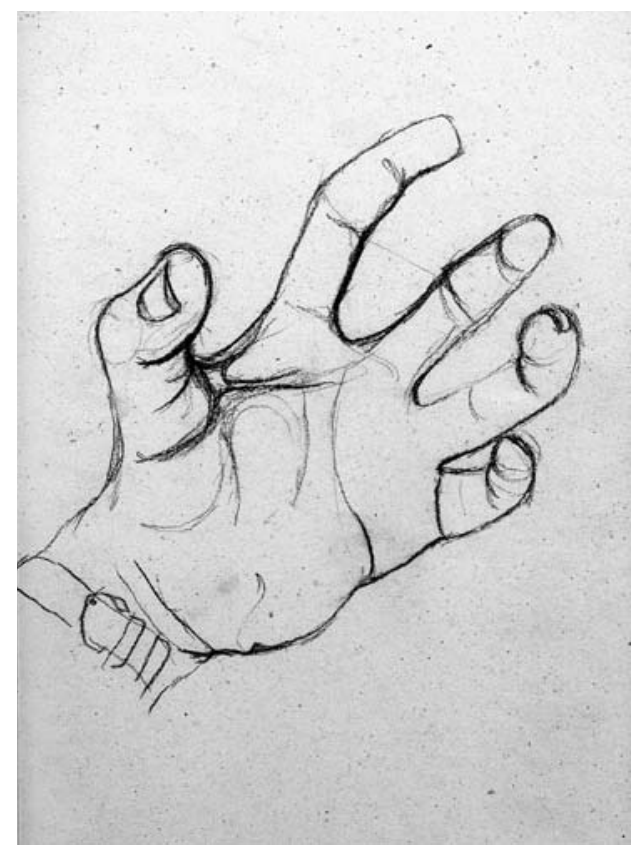

César M.

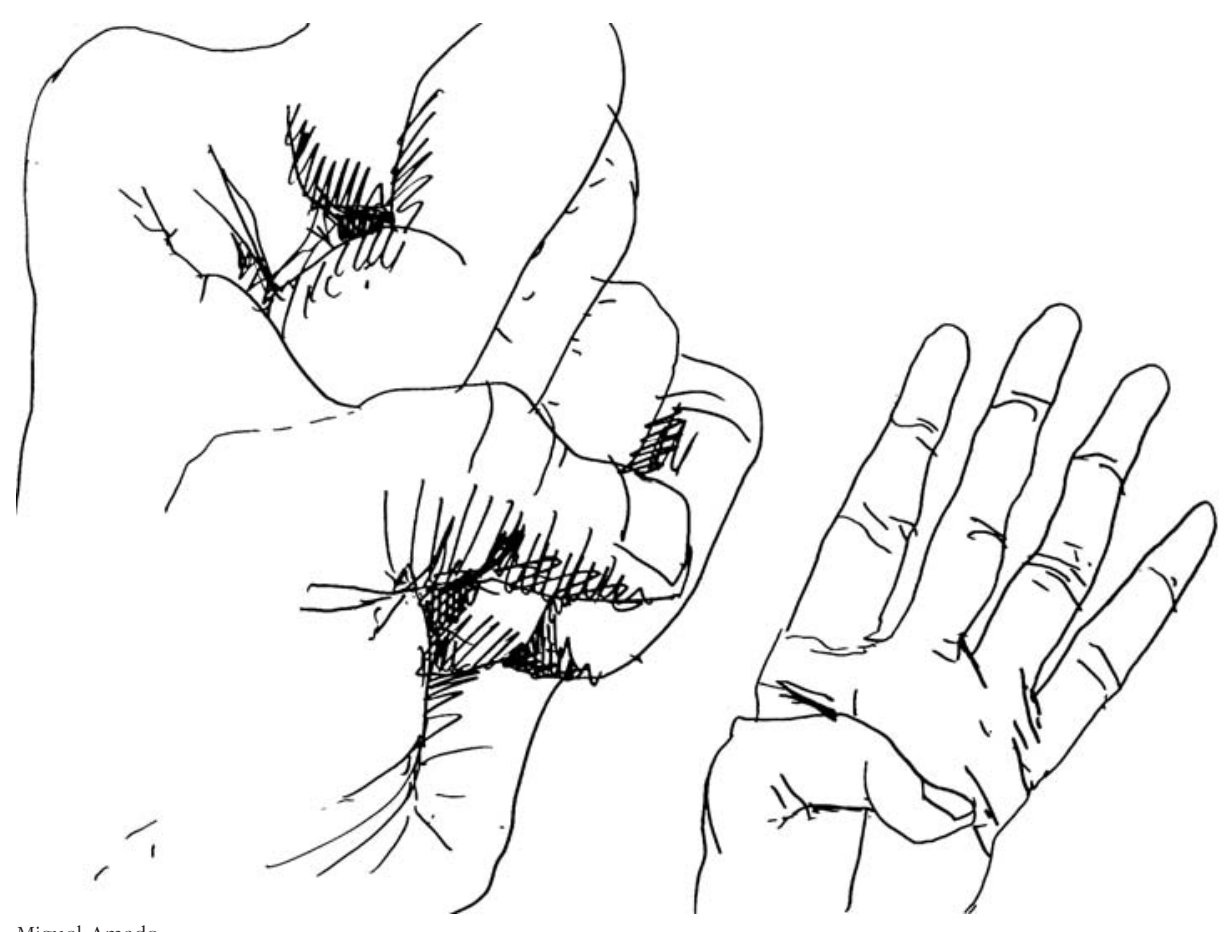

Miguel Amado 

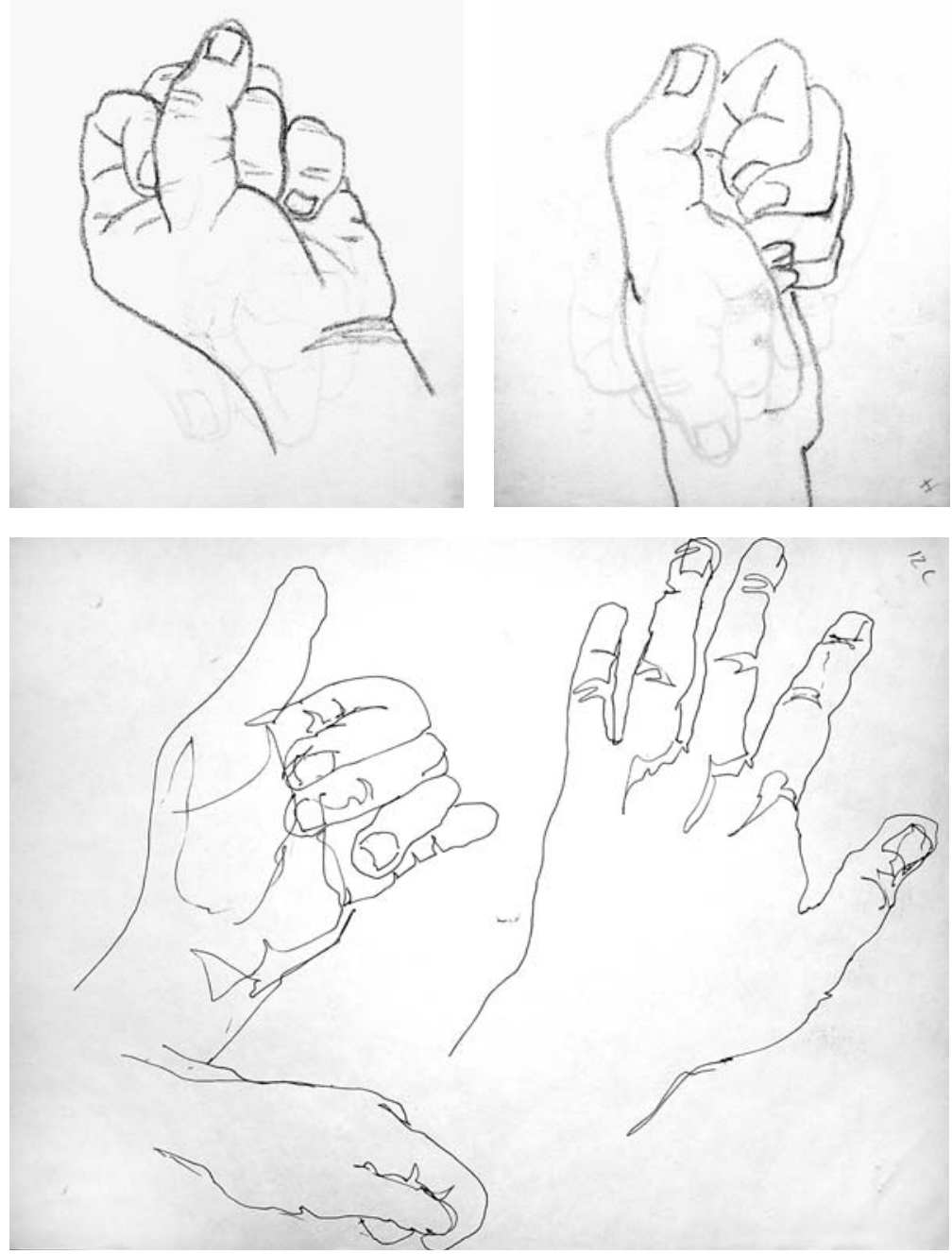

João Santos

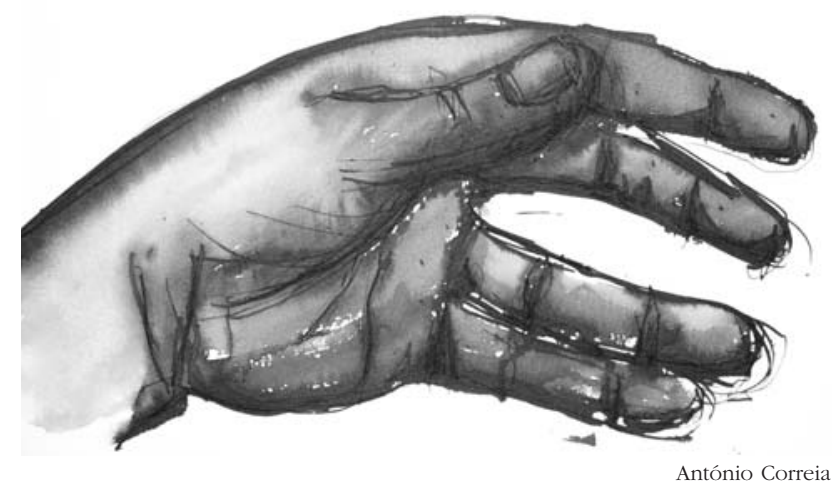



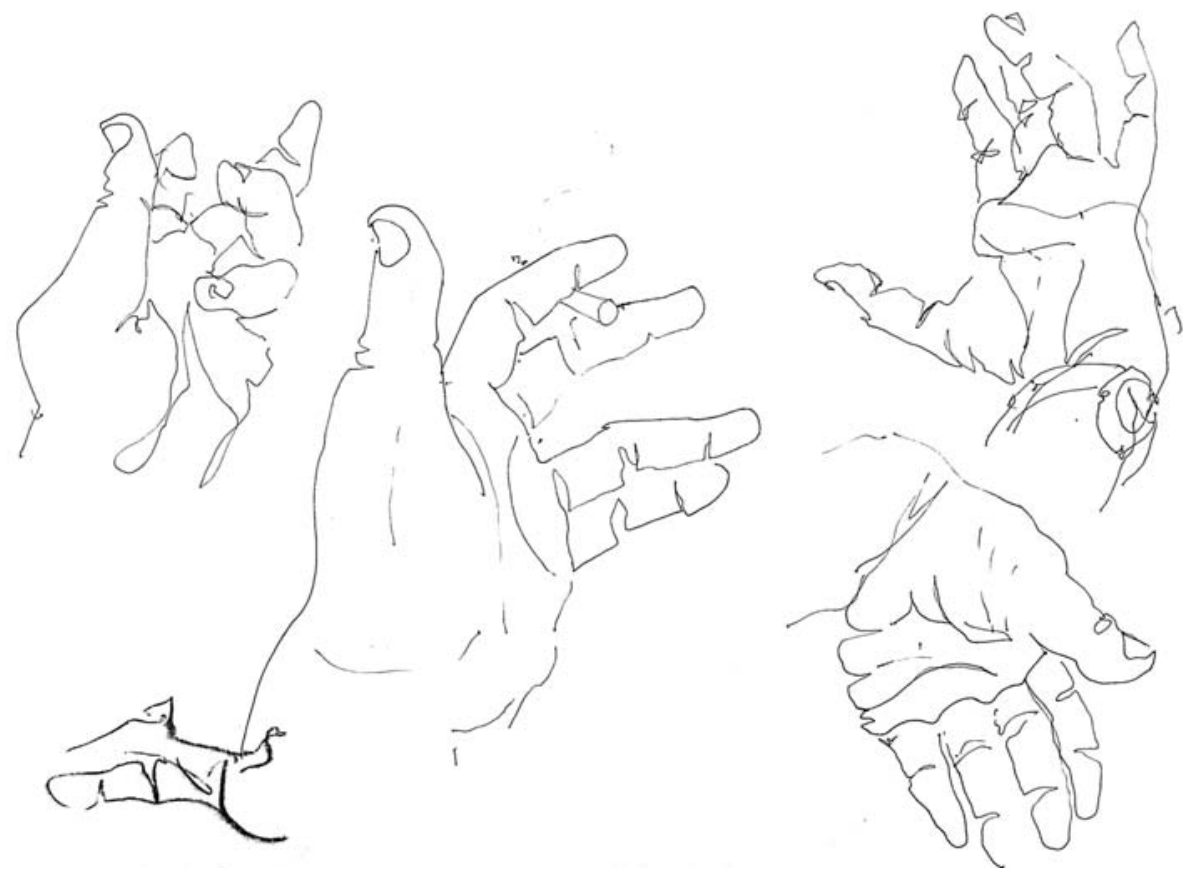

Tiago Rodrigues

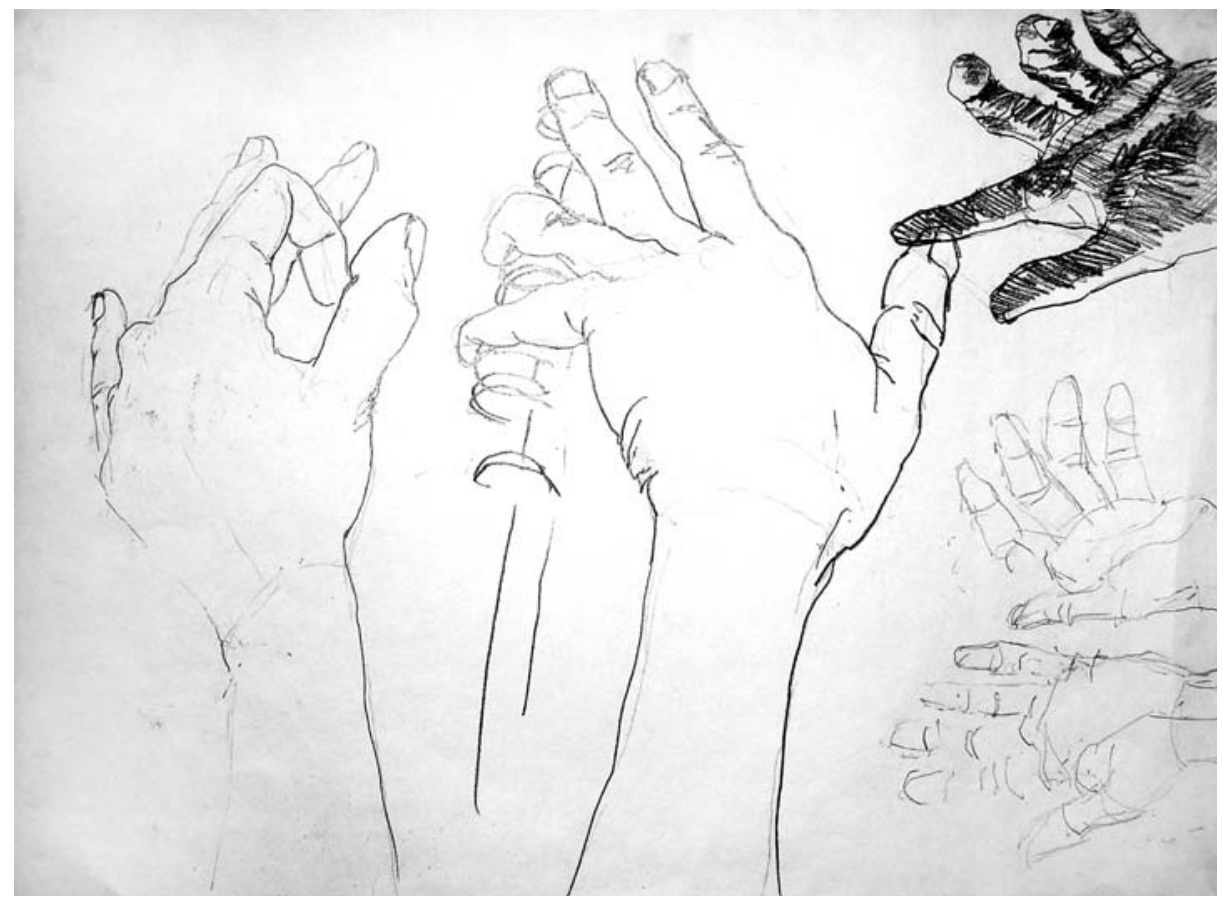

Miguel Amado 

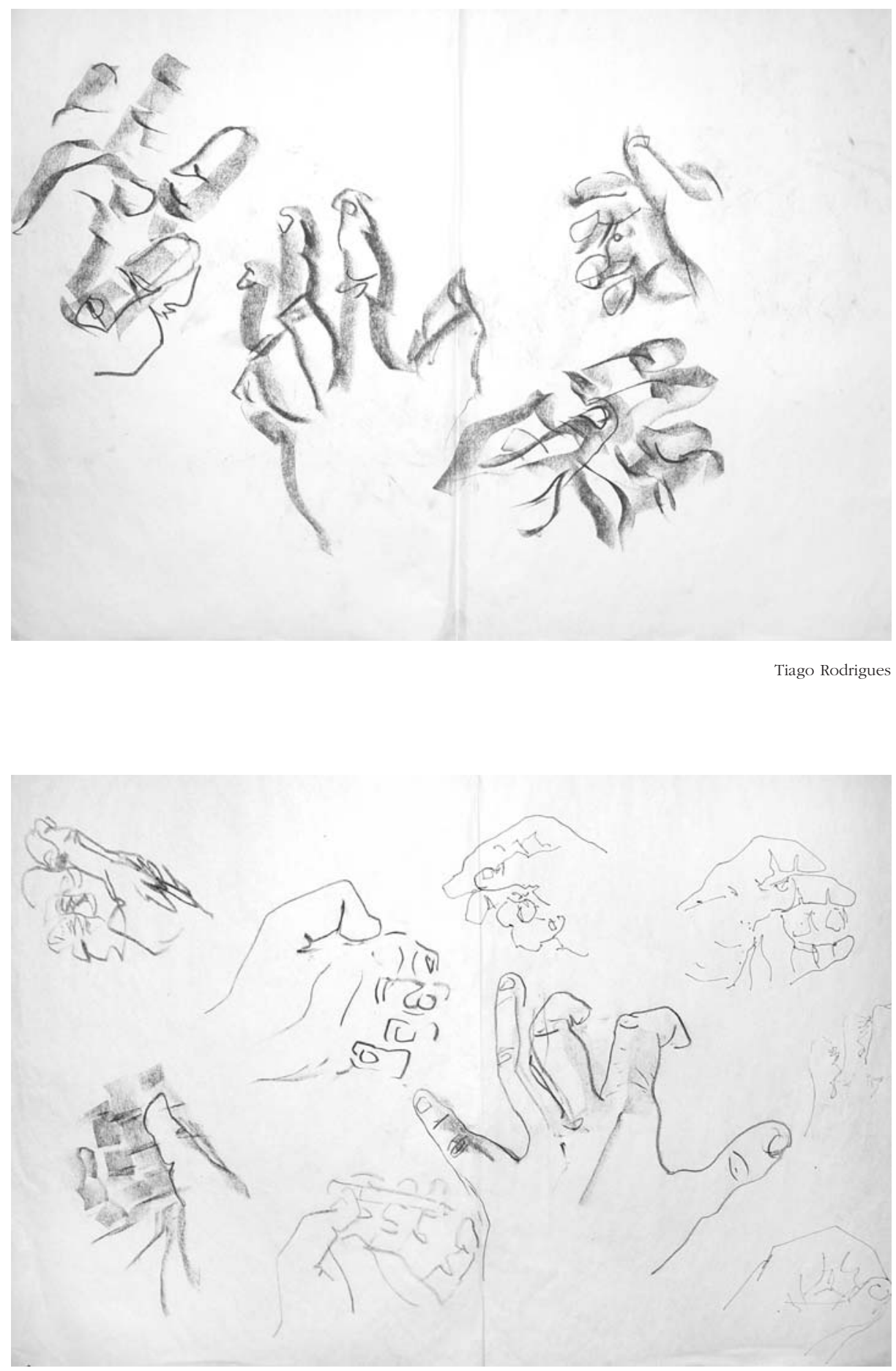

Tiago Rodrigues 



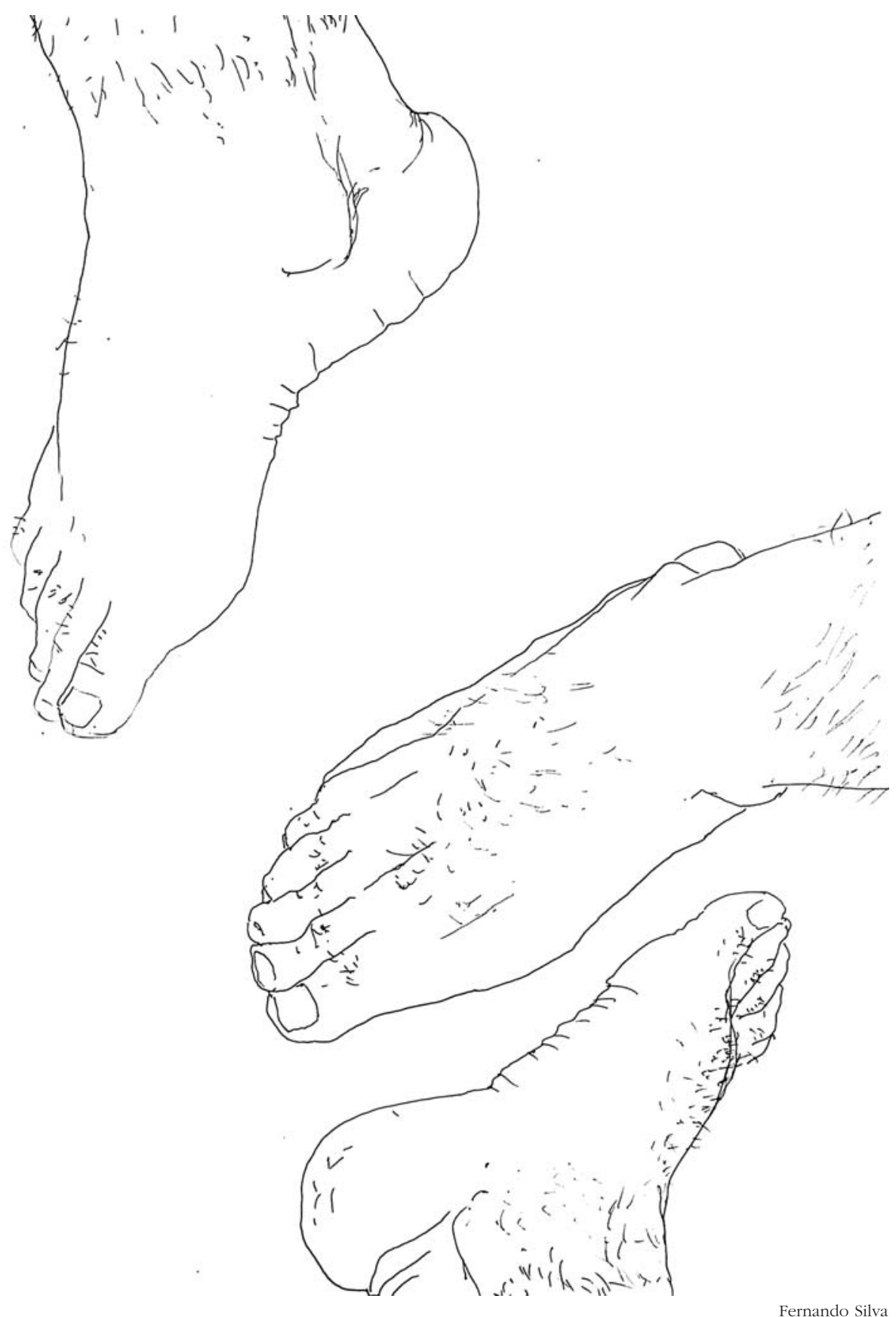




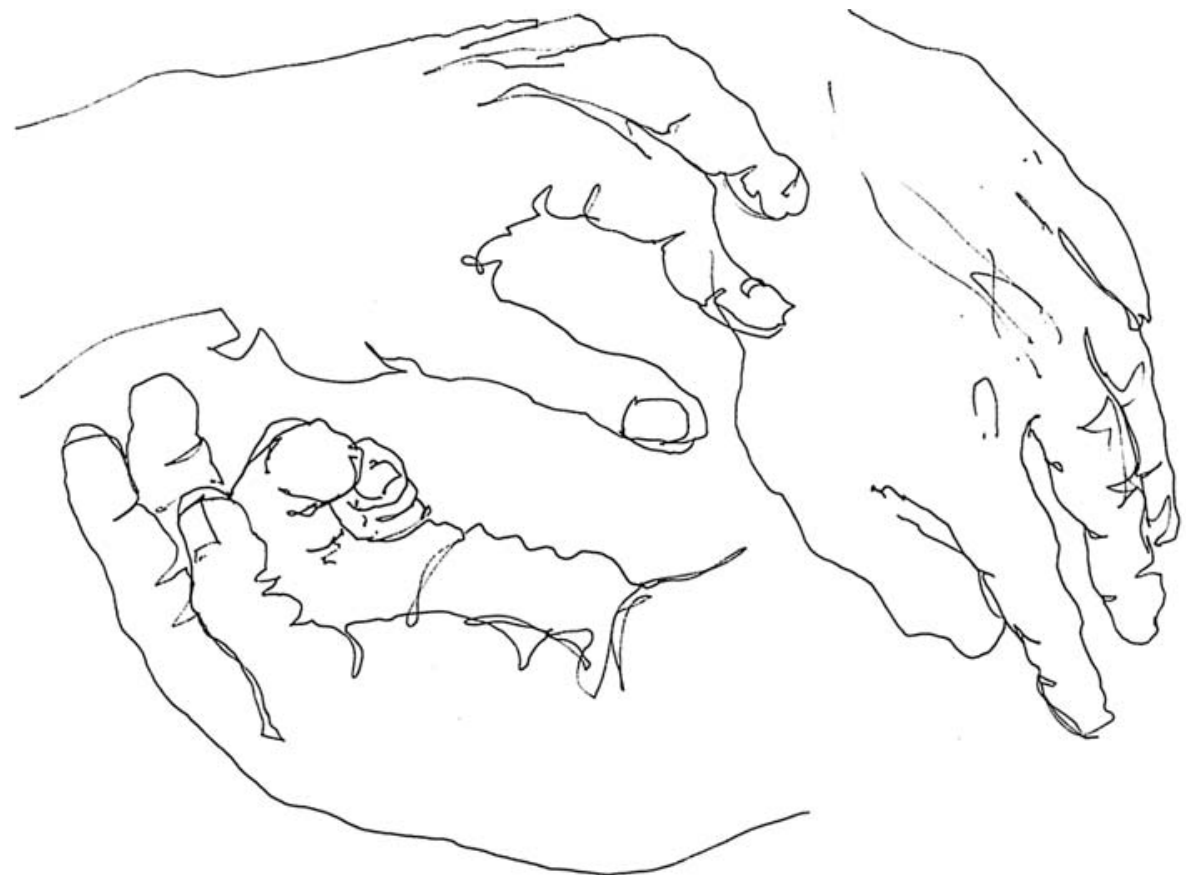

João Santos

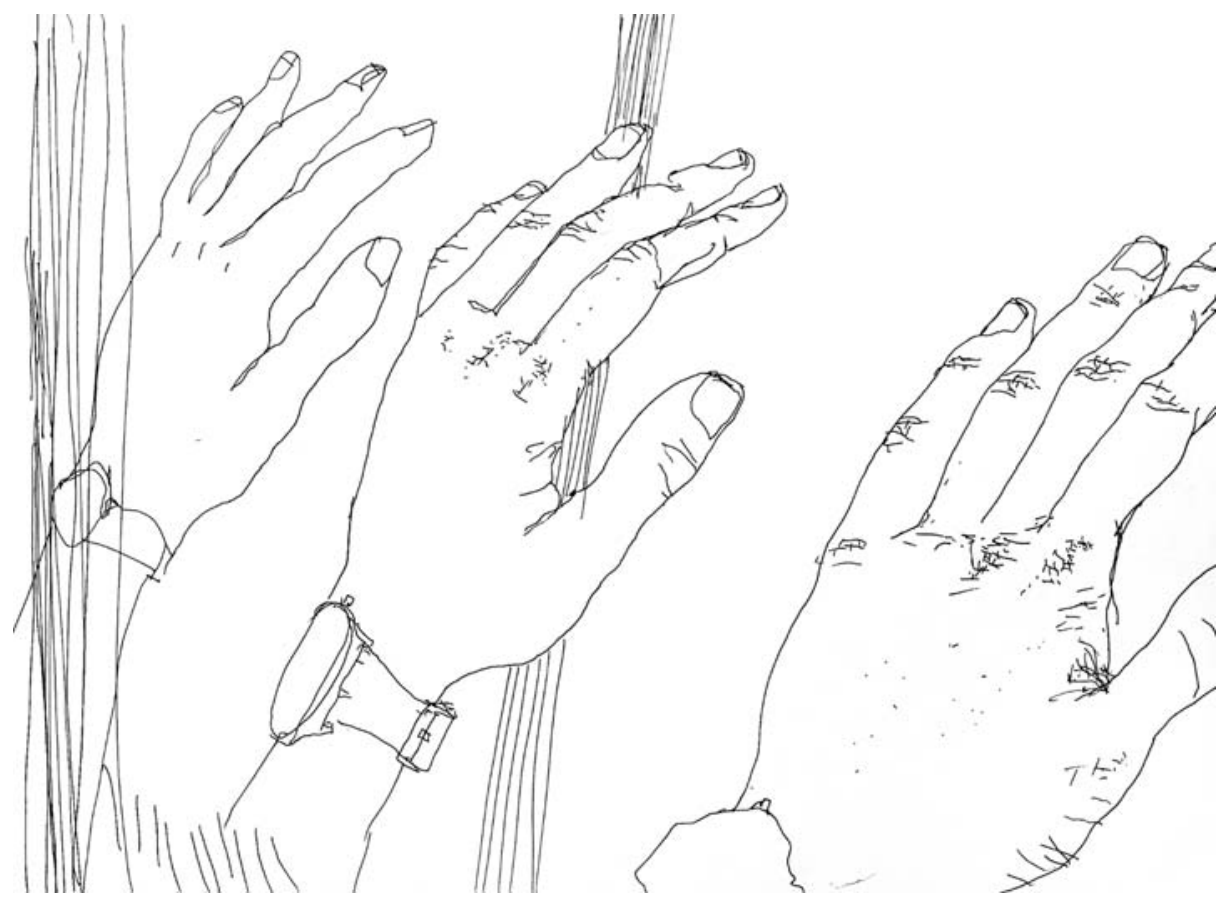

Miguel Amado 


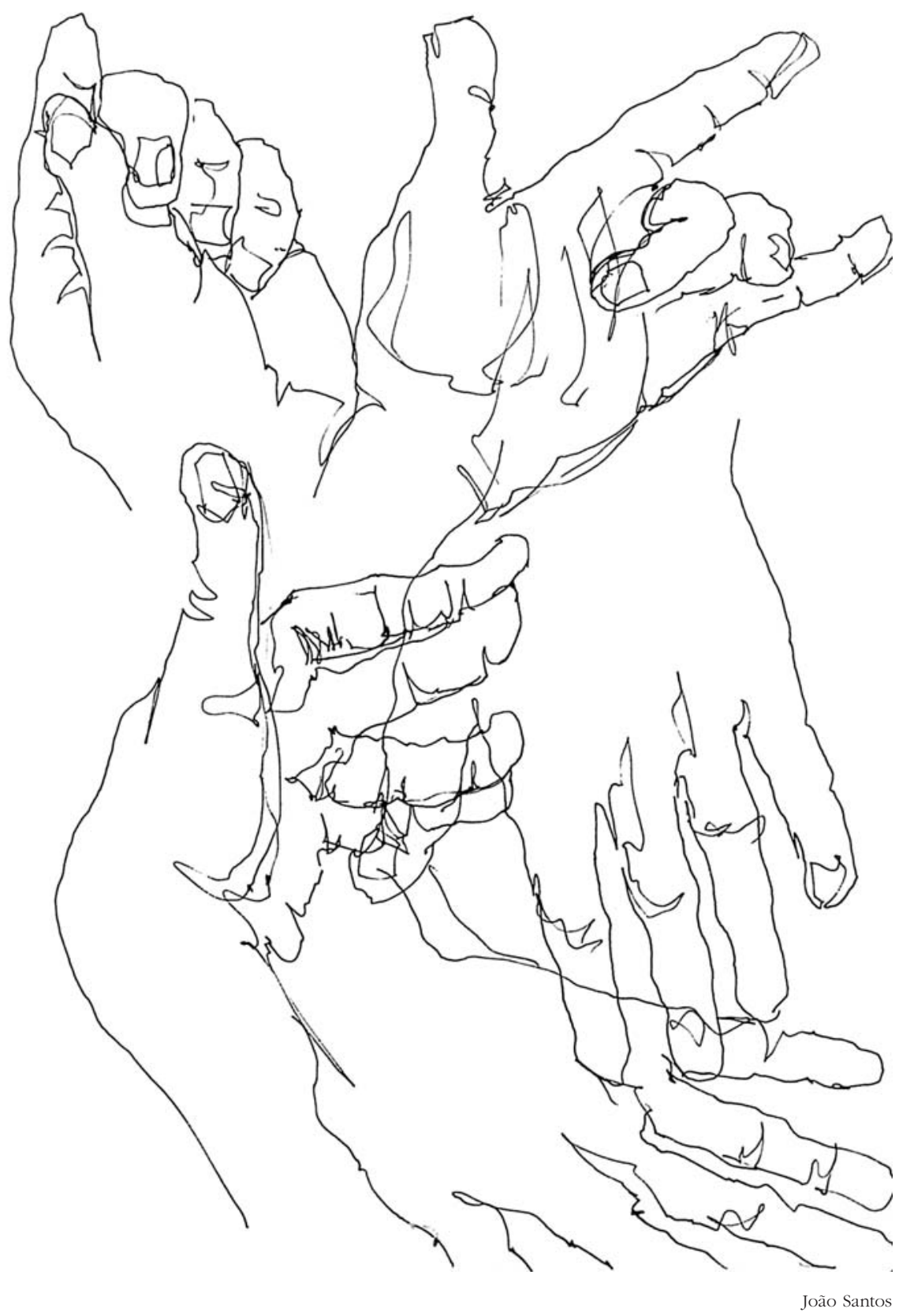


(Página deixada propositadamente em branco) 
DA PLASTICIDADE CALIGRÁFICA À PLASTICIDADE COMPOSITIVA 
(Página deixada propositadamente em branco) 
Nestes exercícios a fluência e agilidade para que os próprios instrumentos estão vocacionados será factor de desenvolvimento de uma destreza gráfica.

Para além dos valores plásticos que estes instrumentos podem possibilitar interessa aqui a agilidade na relação com a manualidade do desenho, em registos cuja qualidade é sobretudo resultado da destreza, numa relação fluente entre decisão e gesto.

Ao mesmo tempo, desenhar com pincel e tinta desenvolve a sensibilização para a plasticidade da caligrafia.

À semelhança da escrita oriental aqui também será desenvolvida a artisticidade do registo caligráfico.

Sendo elementos vegetais os modelos ponto de partida para estes exercícios, a organicidade da manualidade, do gesto na sua relação surgem em empatia com o que é figurado.

Um ramo pode ser um único gesto, uma folha um sinal gráfico.

E, na relação com a folha suporte, que absorve a tinta, que reage na criação de diferentes valores texturais de acordo com diferentes diluições dos pigmentos, desenvolve-se o sentimento da criação de desenhos onde traço, mancha e suporte se fundem num só como se o desenho nascesse da interacs dos esquissos).

Eliminados os acidentes caligráficos procurar encarar as linhas como elementos de composição mais do que a sua inicial vocação figurativista.

Num processo de sucessiva síntese, e, ao mesmo tempo, eliminando e acentuando linhas e/ou manchas, numa relação com a bidimensionalidade do suporte, criar composições de extrema simplicidade onde a imagem da composição praticamente coincida com a sua estrutura, ou seja, onde o decorativismo da composição resida na sua própria estrutura e não na profusão de elementos 
a ela somados.ção dos diferentes materiais, tão mais eficazes quando mais se assemelhem a uma situação onde a mão pareça não fazer mais do que fazer as formas nascer, fazendo corresponder aos vegetais, elementos da natureza, desenhos onde o artifício parece transformar-se em naturalidade.

$\mathrm{Na}$ orientação dos gestos das densidades, das formas no rectângulo do suporte potencia-se também o desenvolvimento de uma sensibilidade compositiva, num jogo entre a acidentalidade como intencionalidade e o seu domínio, tirando partido das surpresas, em desenhos que surgem da atenção ao efeito de cada registo.

A partir dos desenhos de elementos vegetais realizados a pincel e tinta da china, criar composições a tinta da china preta, num processo que começa por eliminar os aspectos caligráficos dos desenhos na procura das linhas essenciais (desenhando sobre os desenhos, utilizando papel vegetal para estilização das linhas essenciais (desenhando sobre os desenhos, utilizando papel vegetal para estilização das linhas dos esquissos).

Eliminados os acidentes caligráficos procurar encarar as linhas como elementos de composição mais do que a sua inicial vocação figurativista. Num processo de sucessiva síntese, e, ao mesmo tempo, eliminando e acentuando linhas e/ou manchas, numa relação com a bidimensionalidade do suporte, criar composições de extrema simplicidade onde a imagem da composição praticamente coincida com a sua estrutura, ou seja, onde o decorativismo da composição resida na sua própria estrutura e não na profusão de elementos a ela somados. 

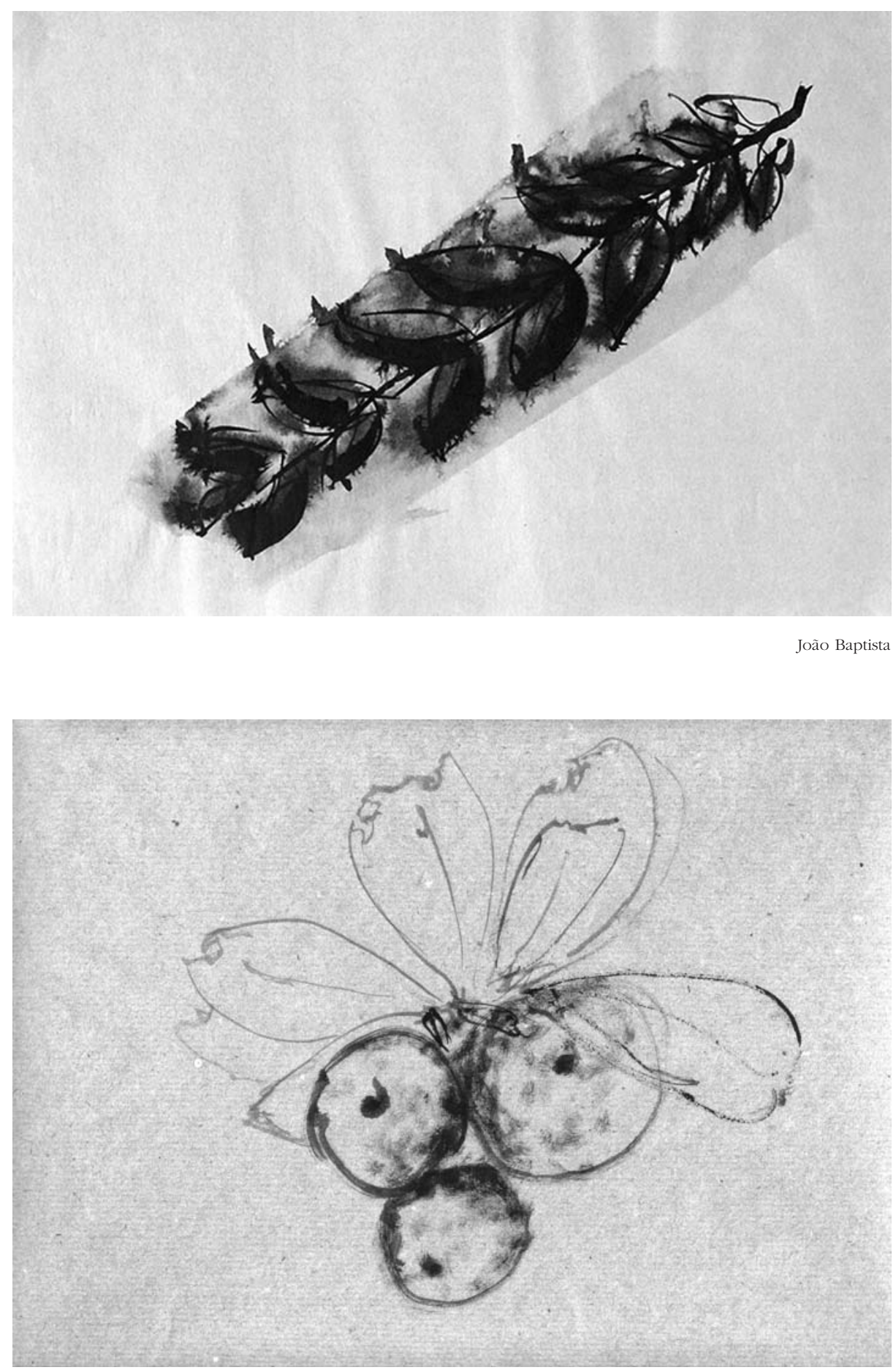

Susete Pereira 


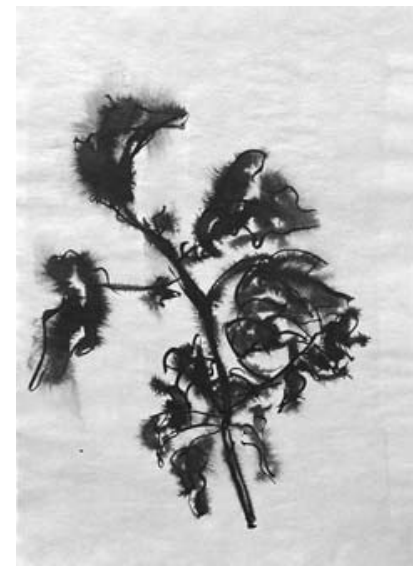

João Baptista

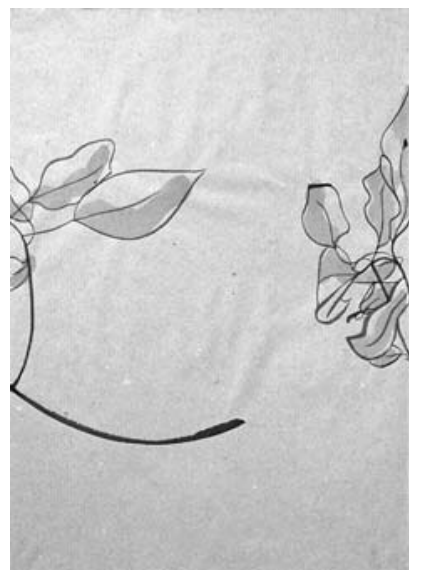

Susete Pereira

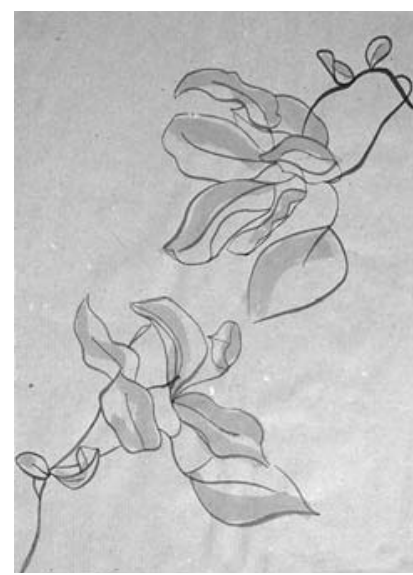

Vera Pinto

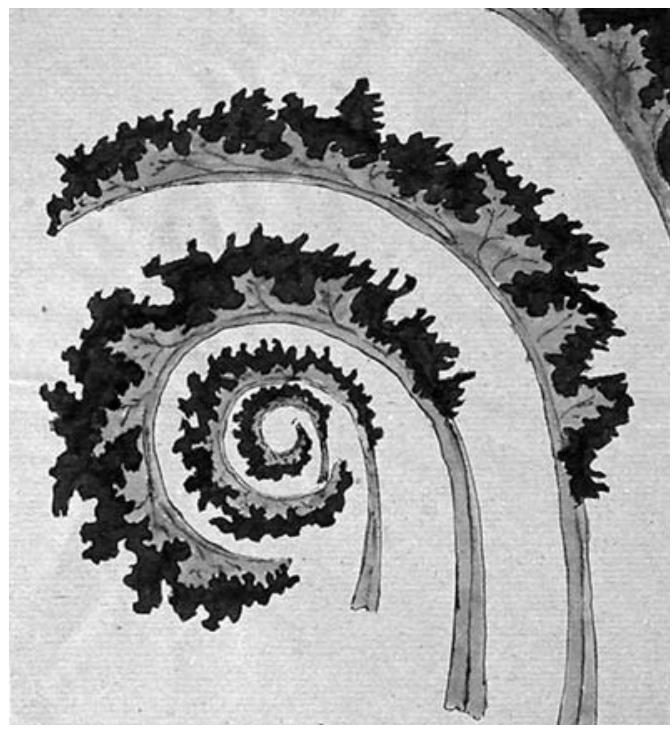

Fernando Silva

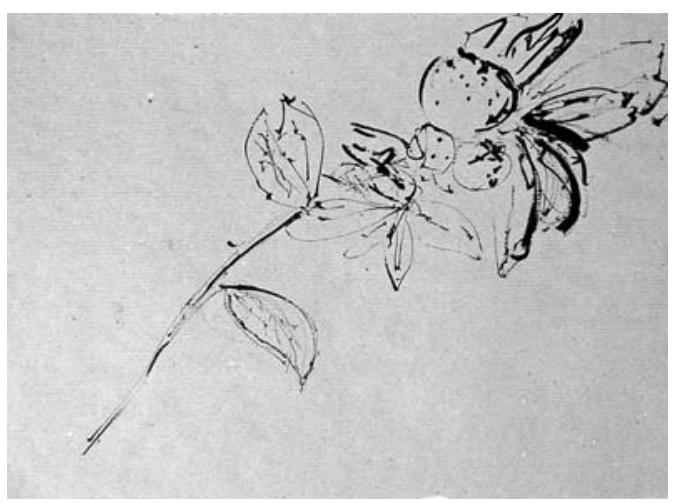

Vera Pinto

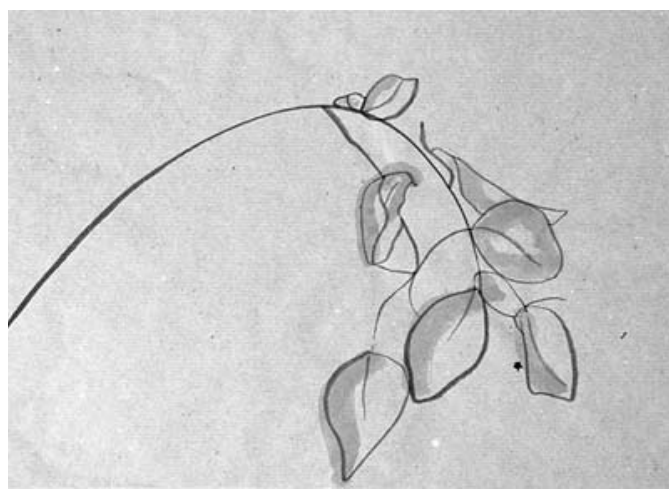

Vera Pinto 
No 


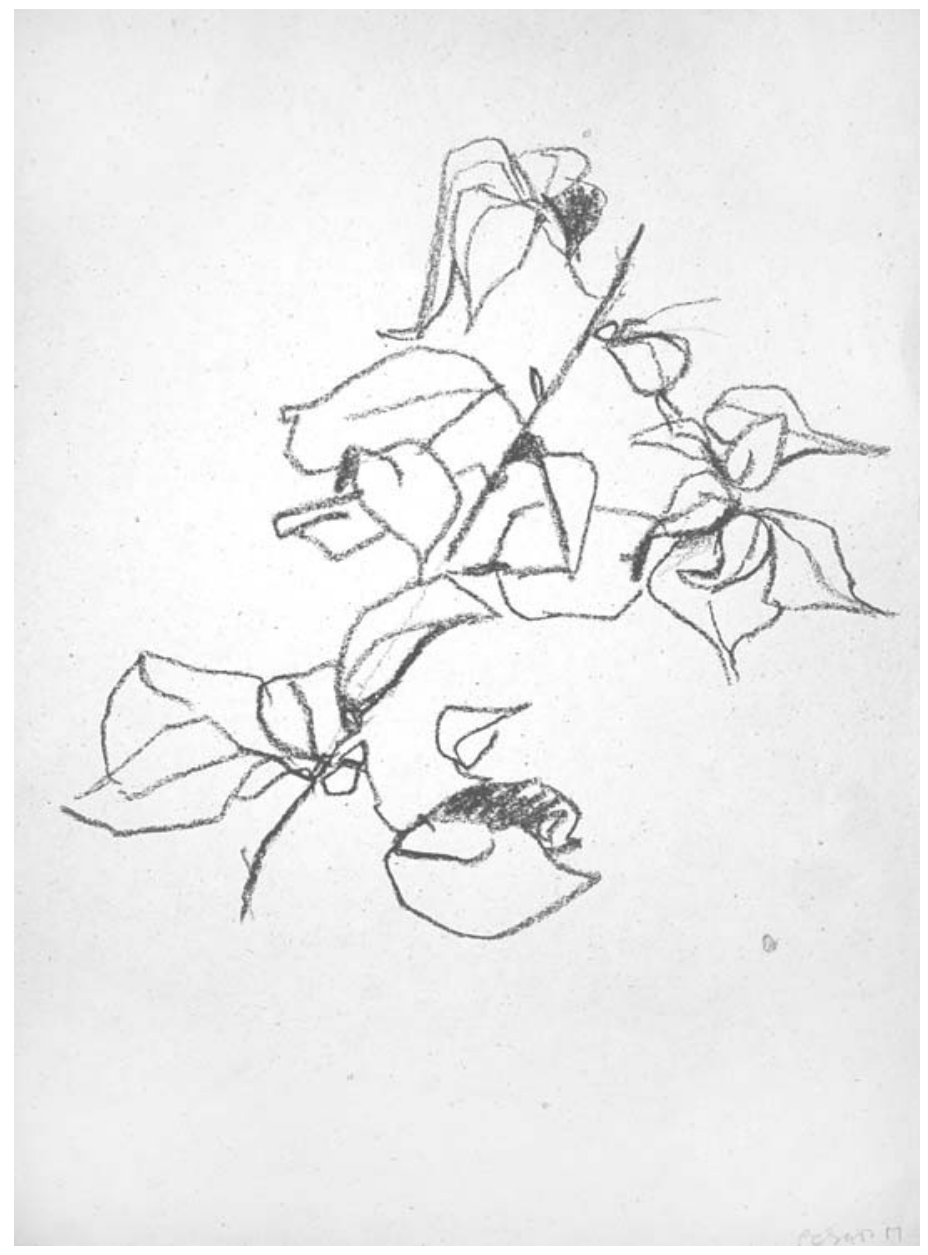

César M.

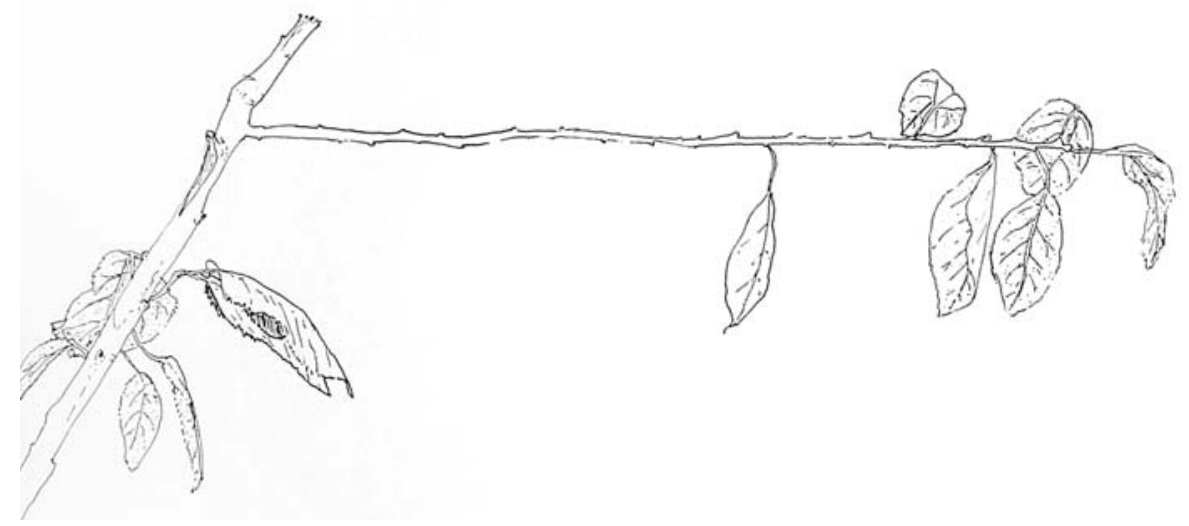

Miguel Amado 

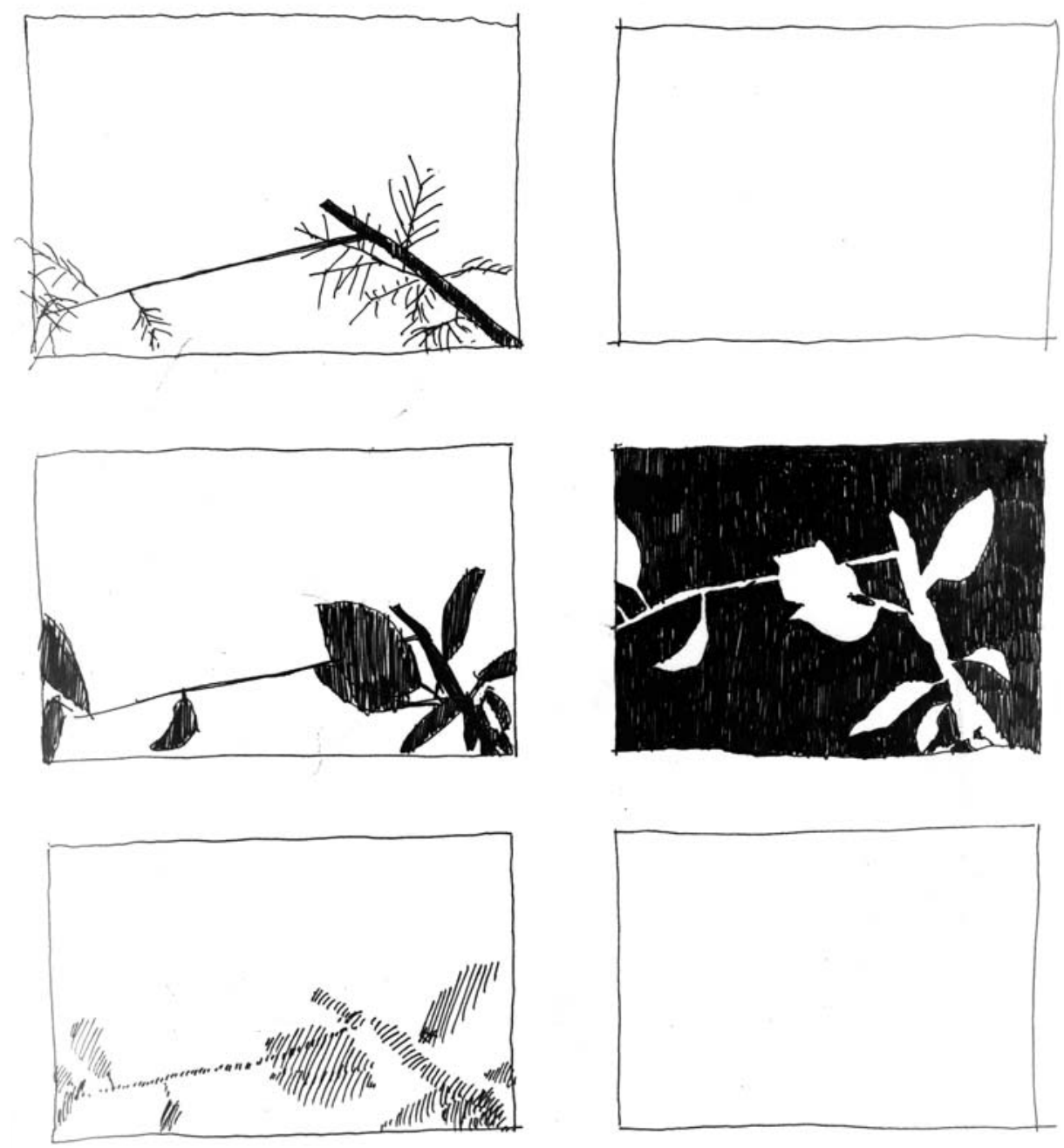

Miguel Amado 

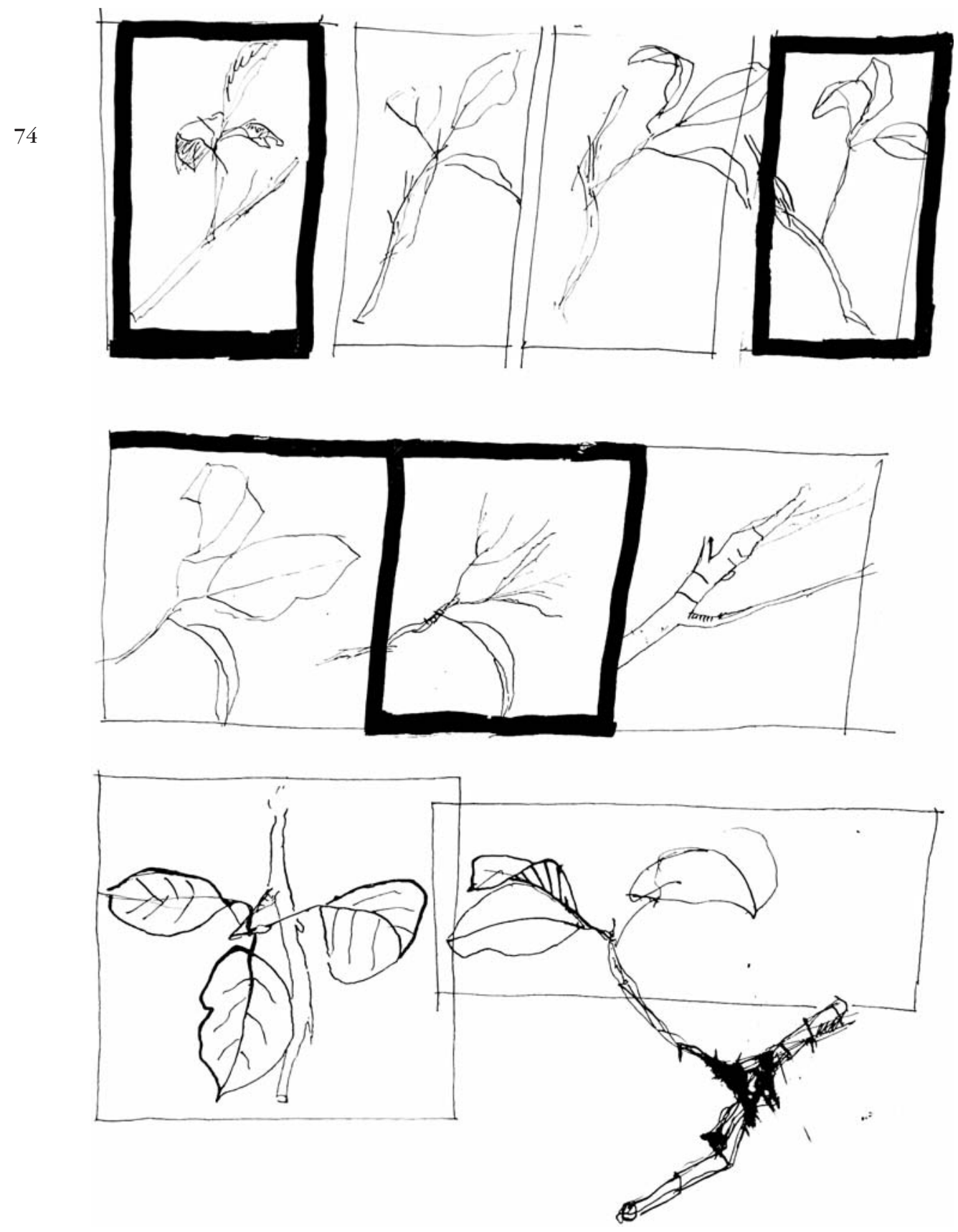

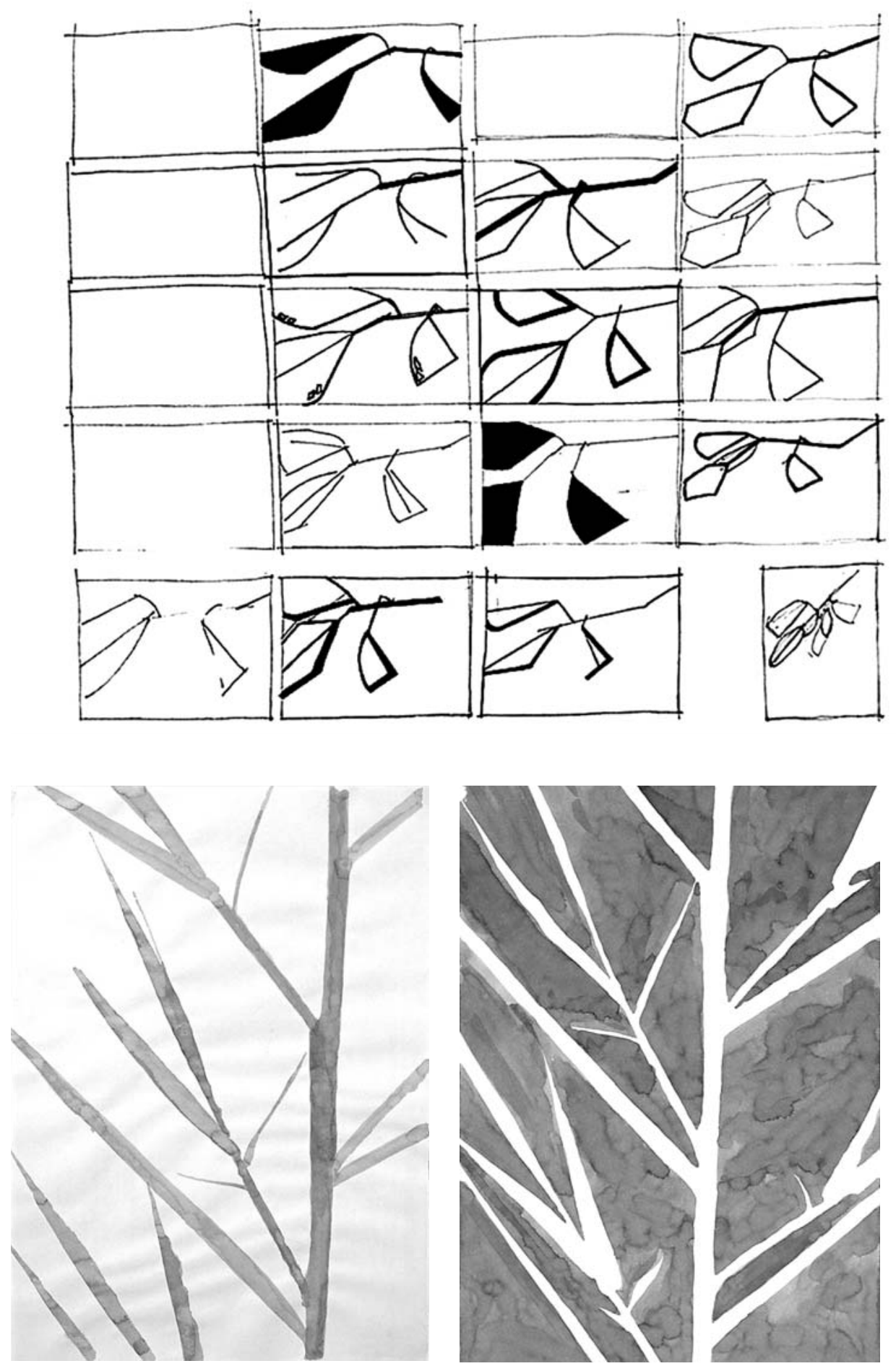

Miguel Amado 


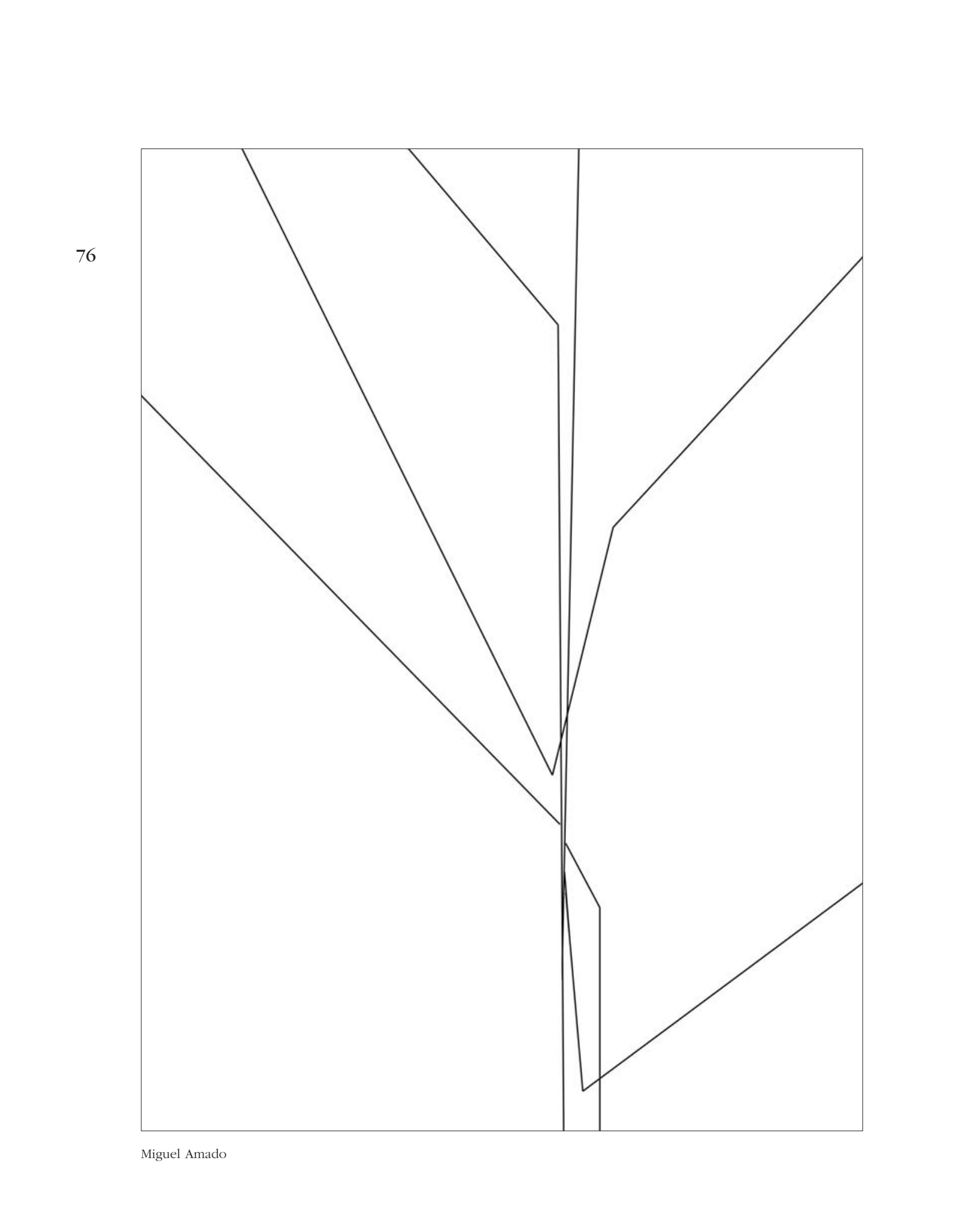




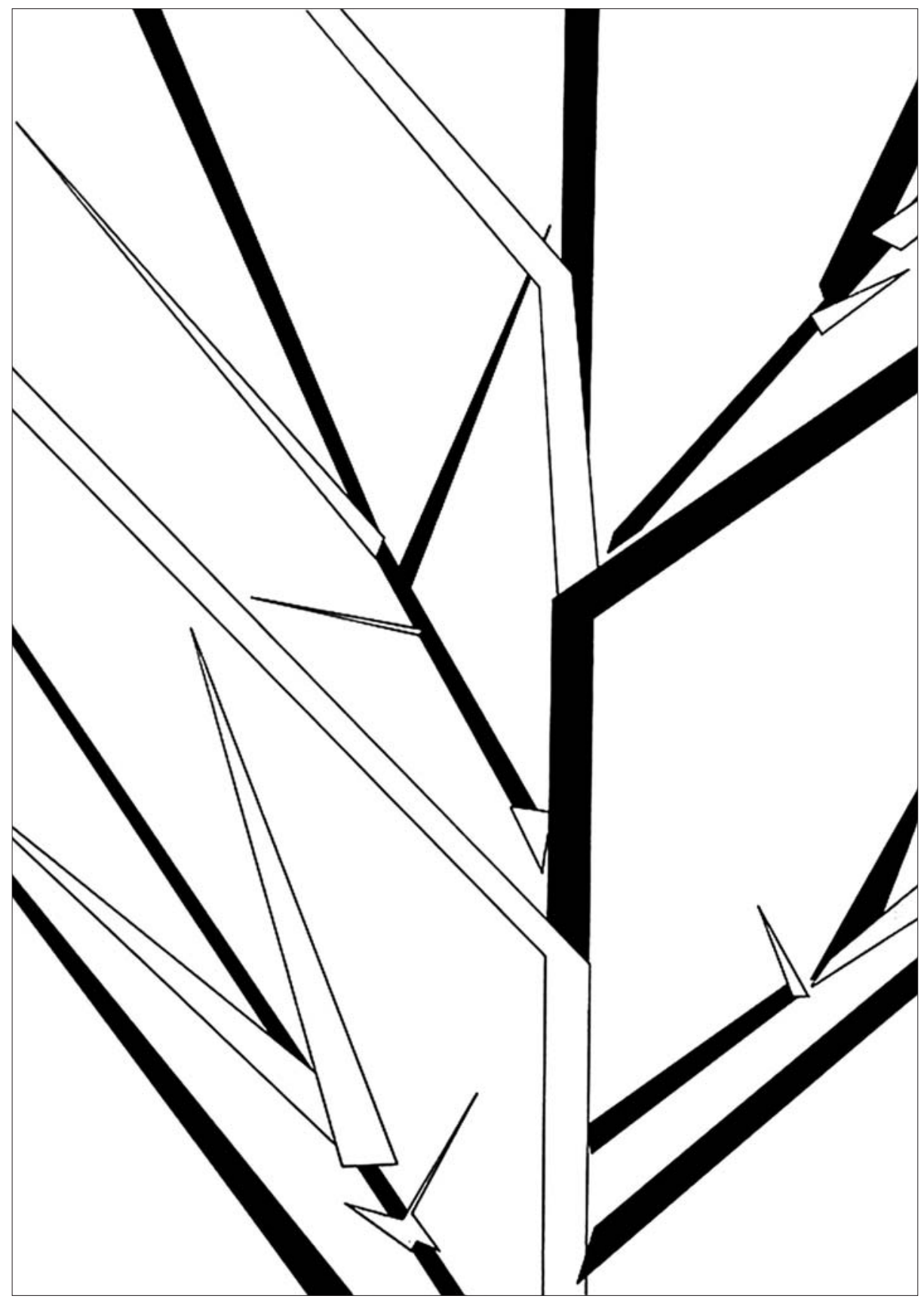

Miguel Amado 


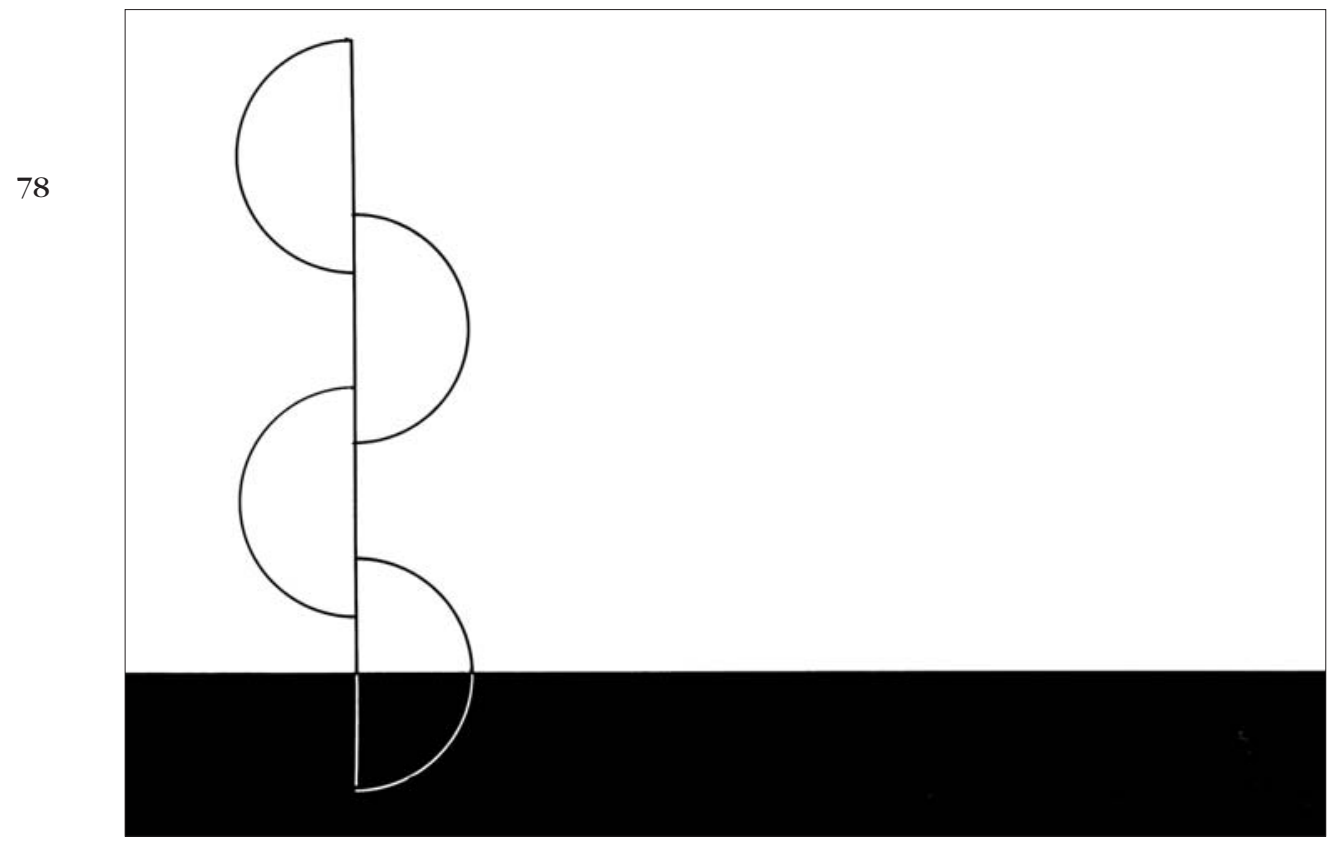

António Correia

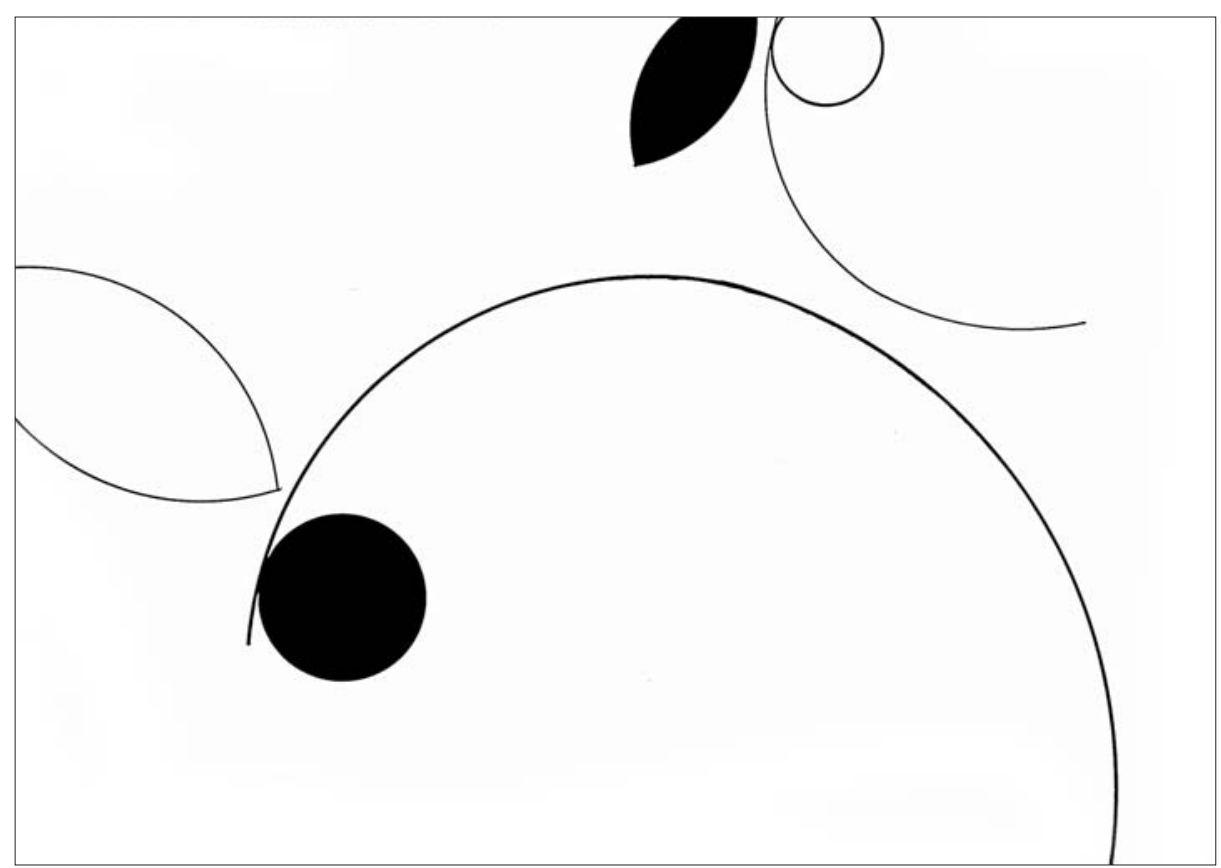

Susete Pereira 


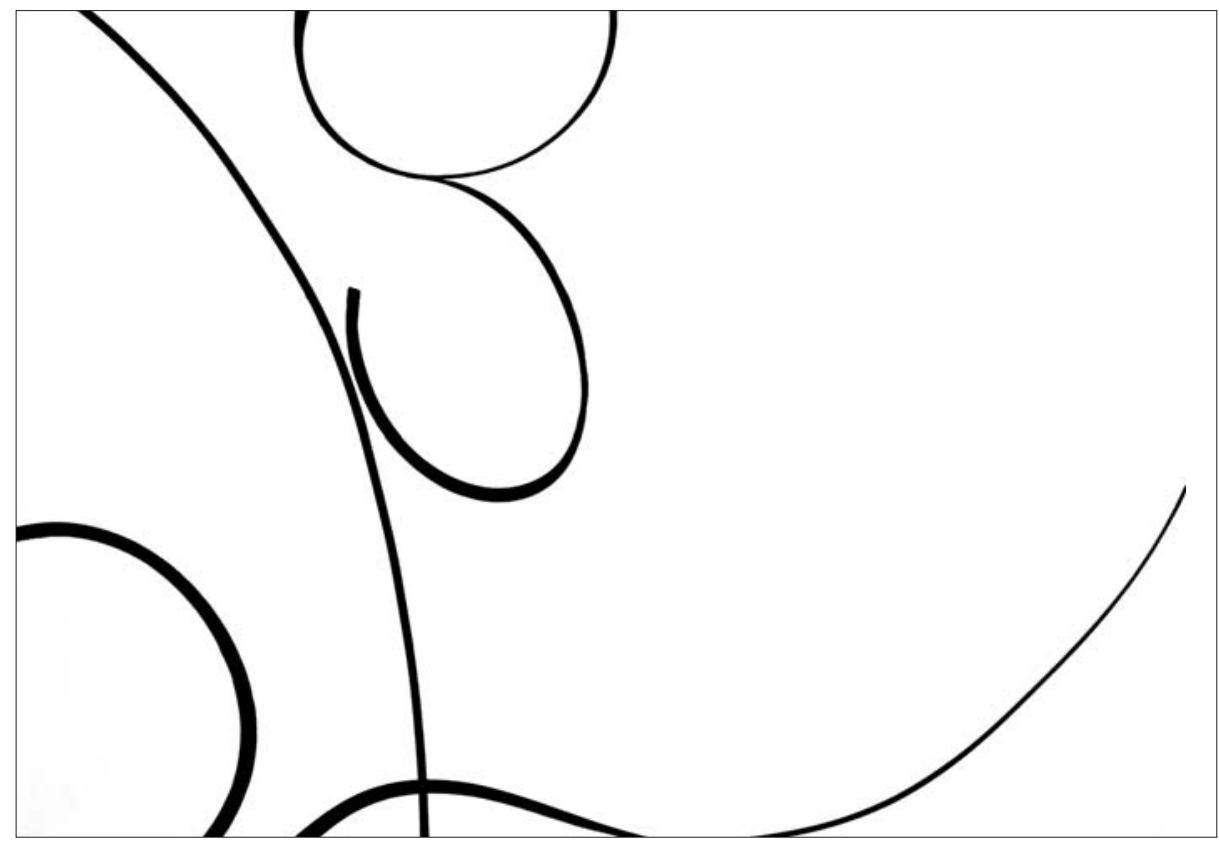

79

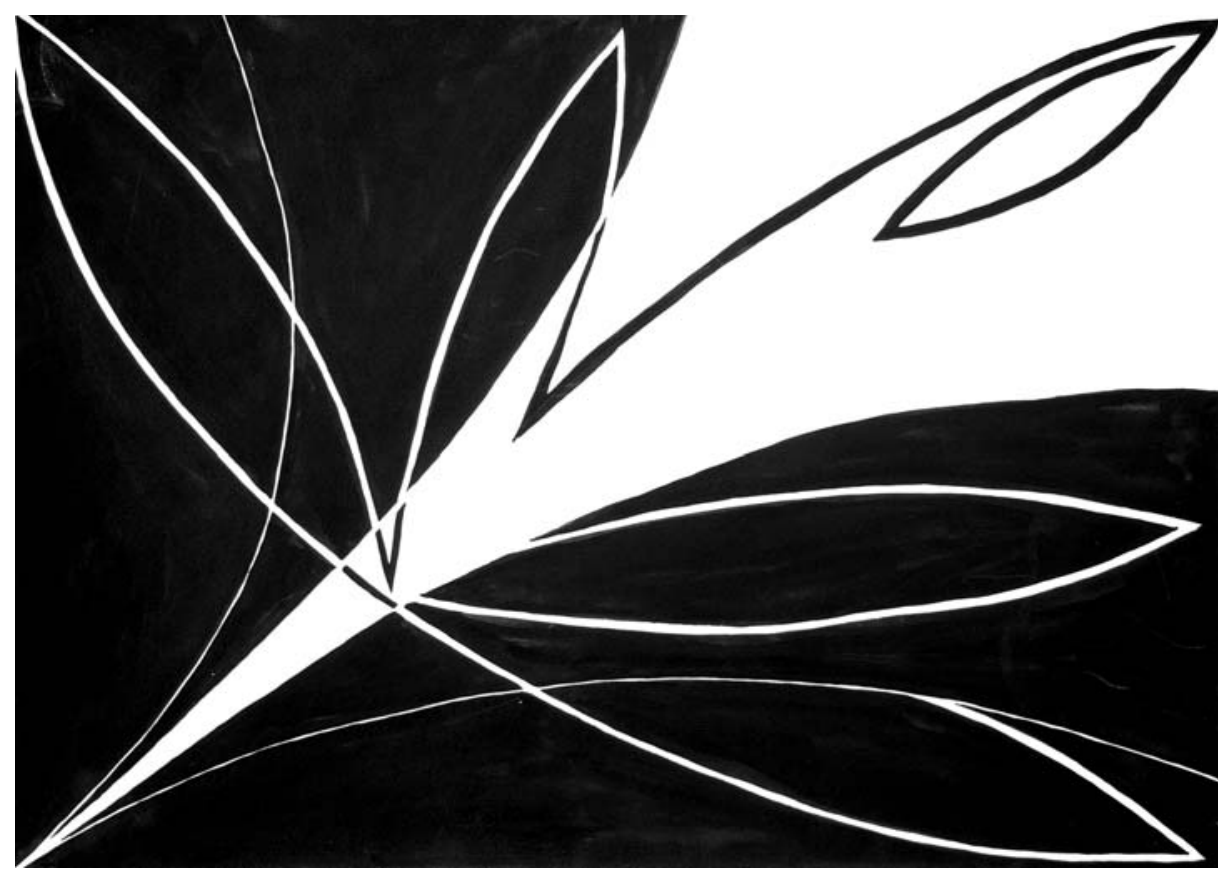

Nélia Filipe 



$$
2
$$




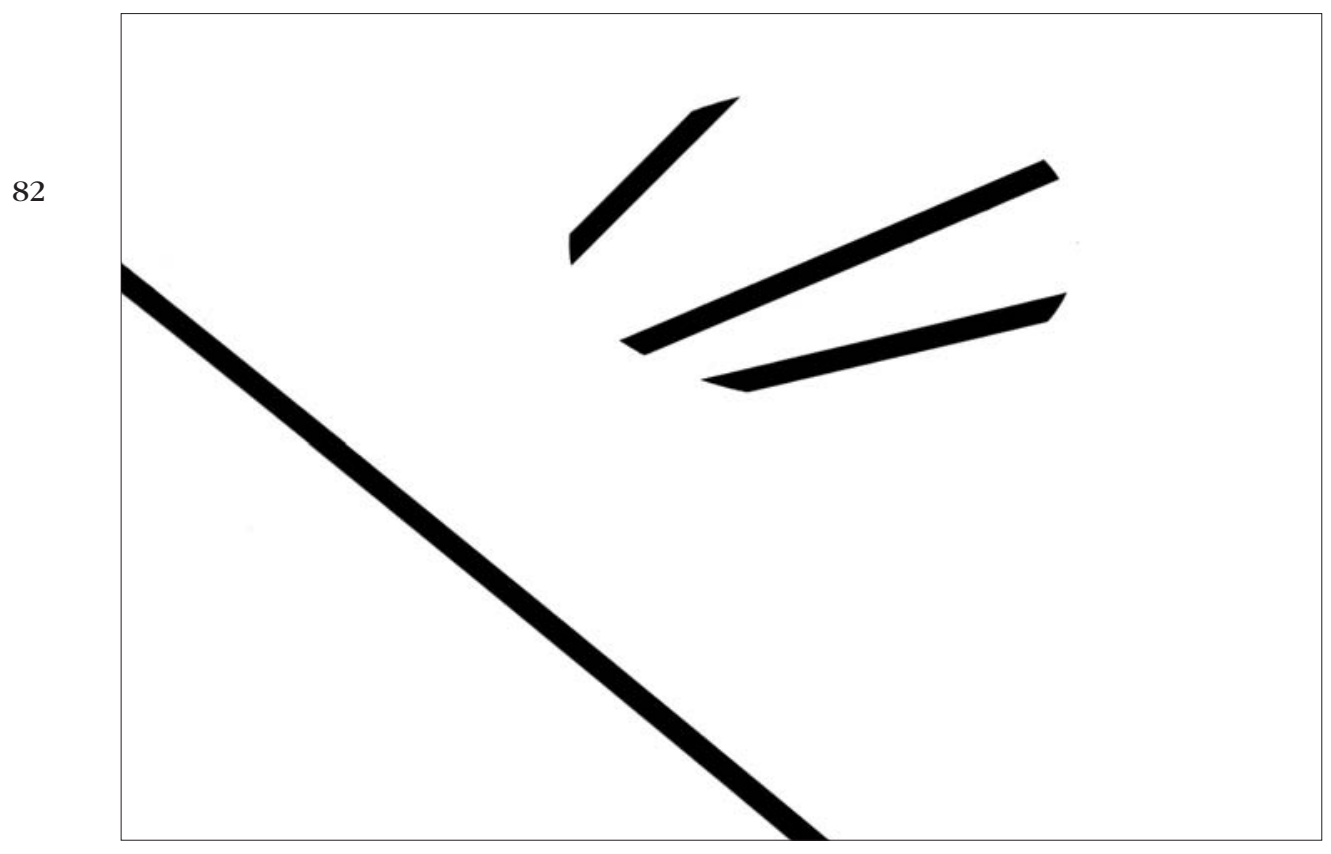

Salomé Galamba

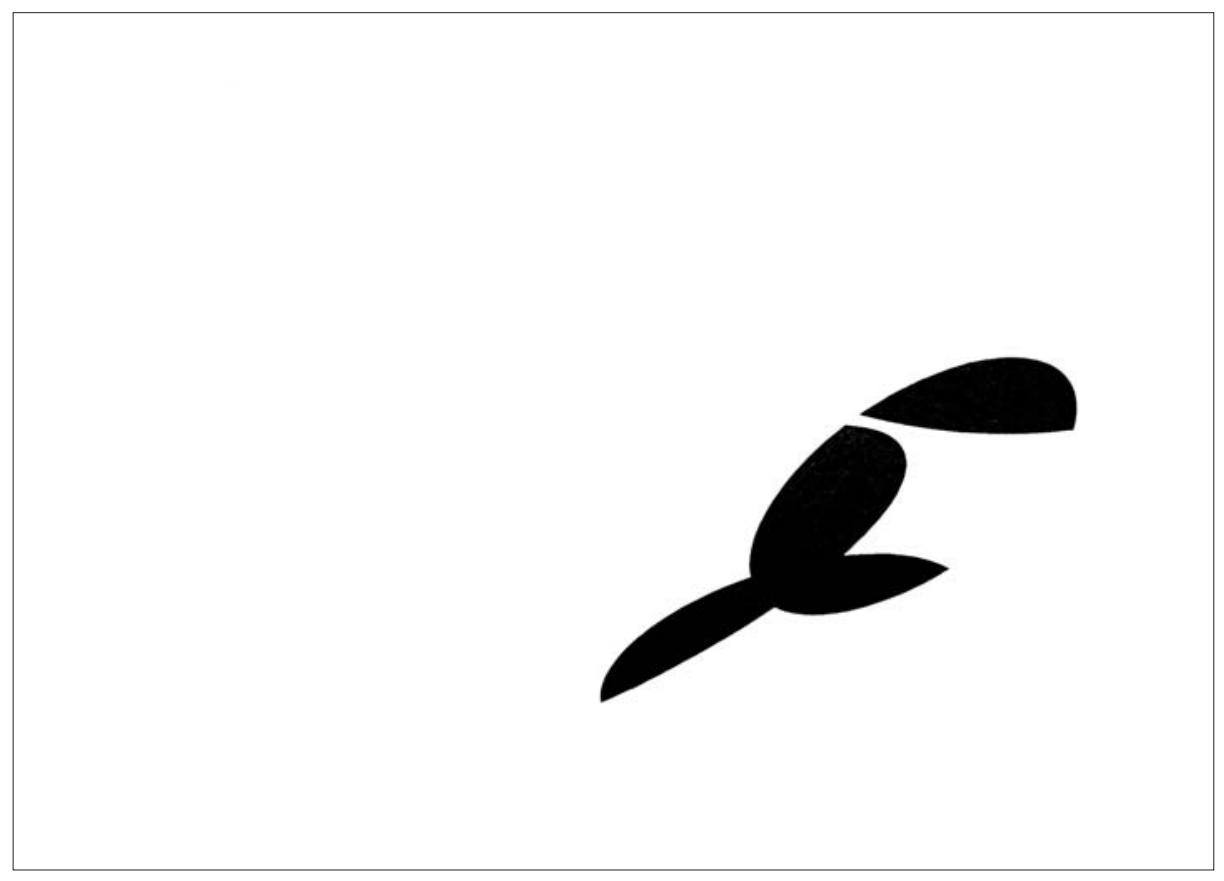

Paulo Luís 


$$
\text { "ge }
$$




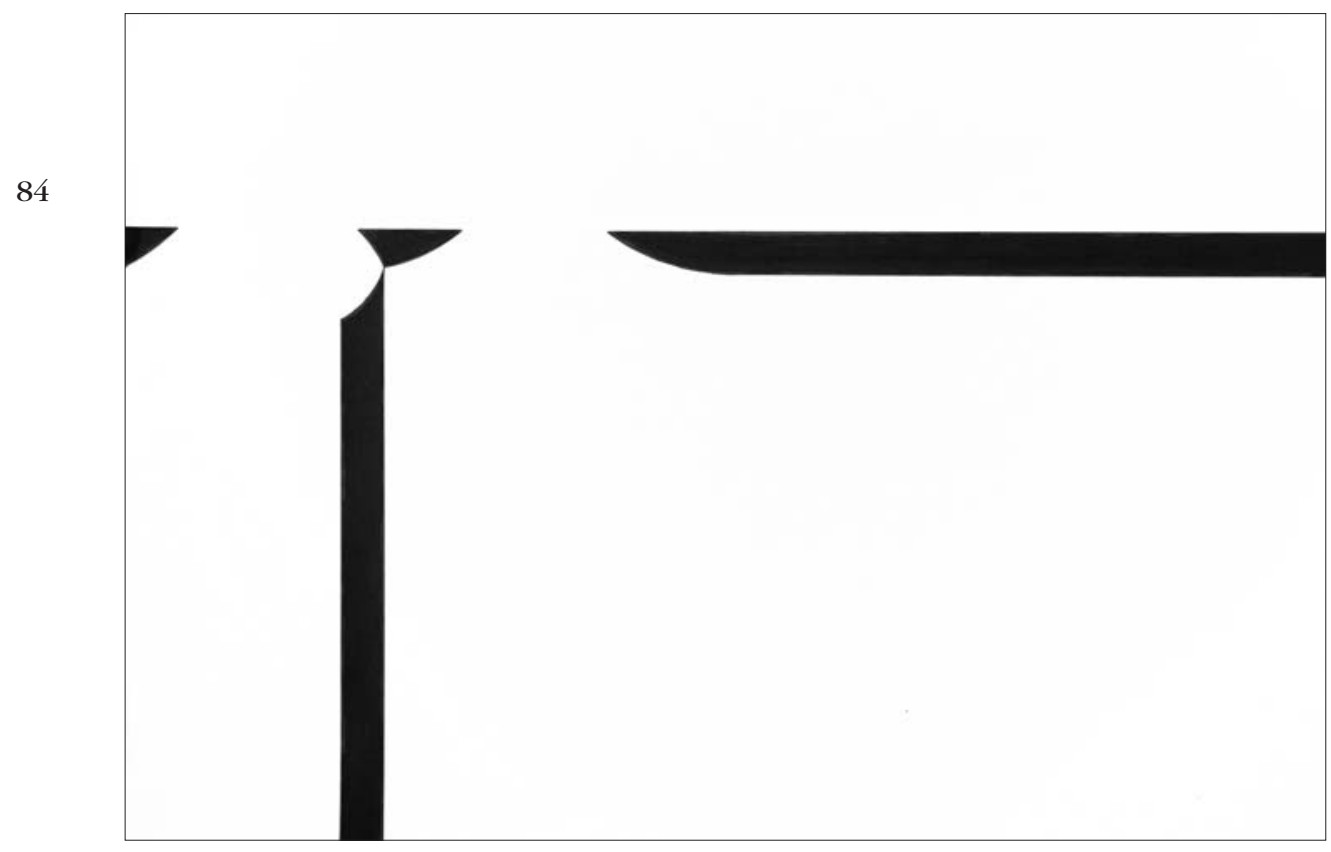

Andreia Couceiro

Estes exercícios compositivos foram também desenvolvidos utilizando papéis recortados e colagens, na memória do decorativismo matissiano, aqui reduzido à essencialidade do preto e branco.

À mudança de material correspondeu uma sensível mudança de atitude.

O acto de recortar prolonga o acto de desenhar, numa relação mais orgânica com o desenho e onde o fazer é uma extensão da concepção.

Estes trabalhos foram condicionados e motivados pelo objectivo de serem expostos, explorando a sua integração no espaço expositivo, explorando situações entre o desenho e a escultura. 

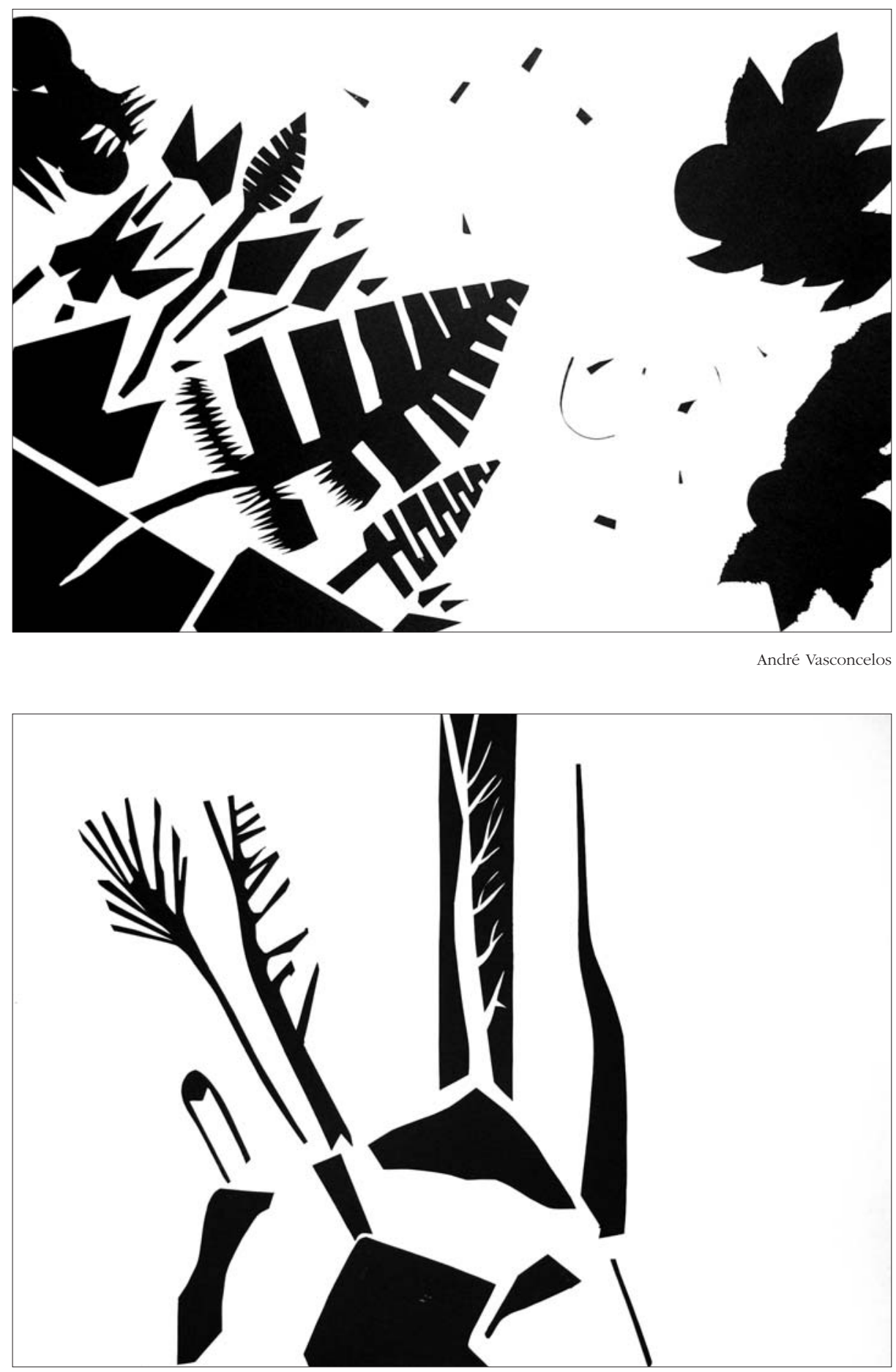


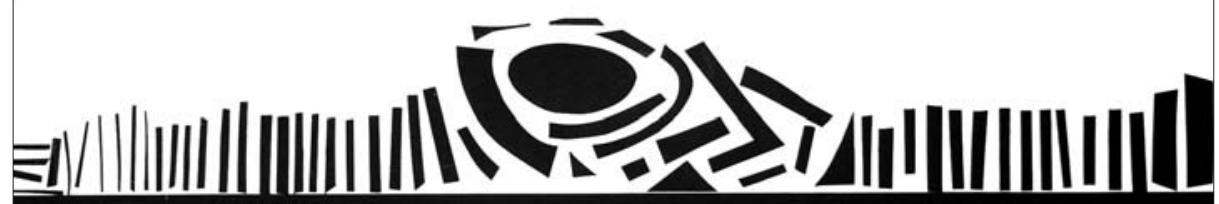

João Crisóstomo

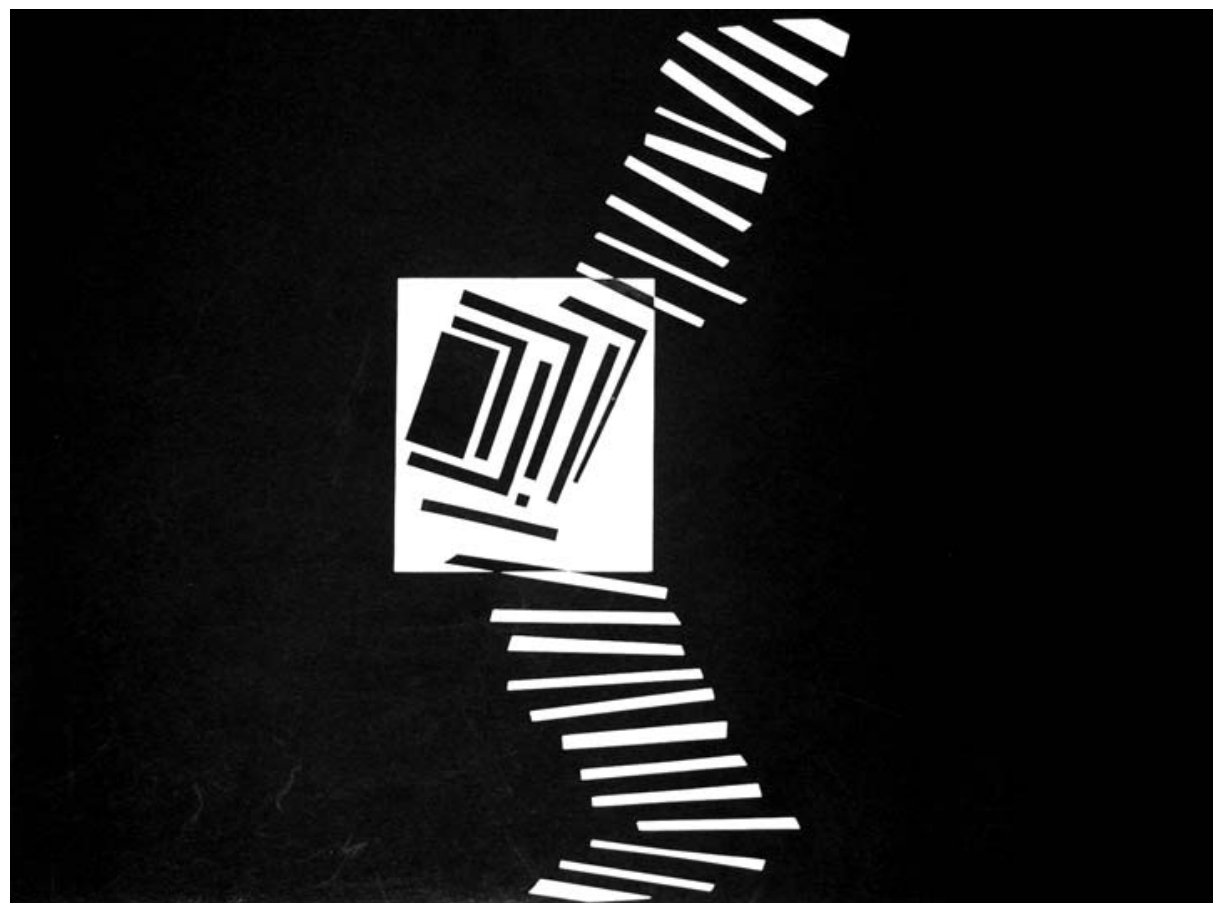




$$
\mathbf{a}
$$




$$
\frac{15}{\text { SRI }}
$$




$$
\begin{aligned}
& \text { (9) } \\
& 10
\end{aligned}
$$




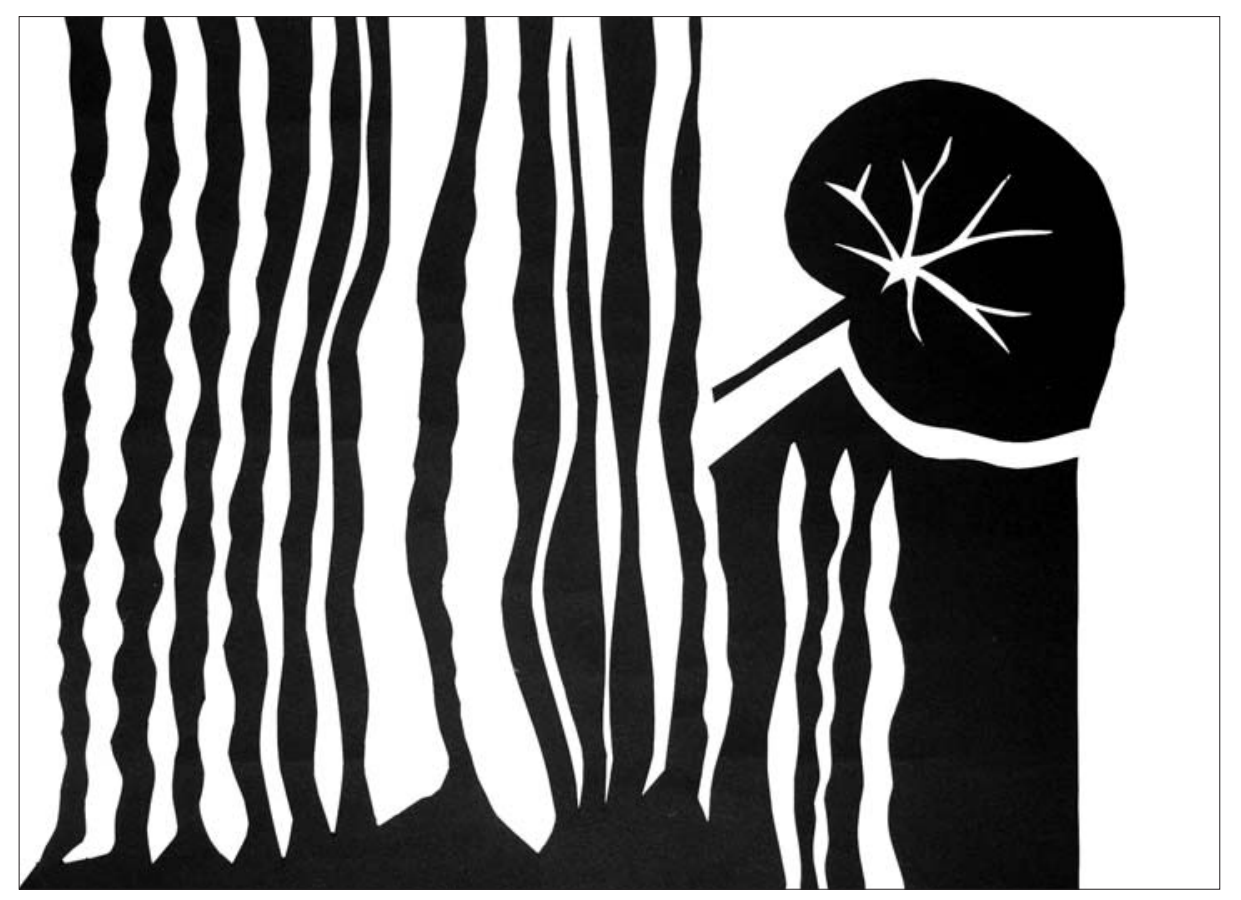

Alexandra Neves

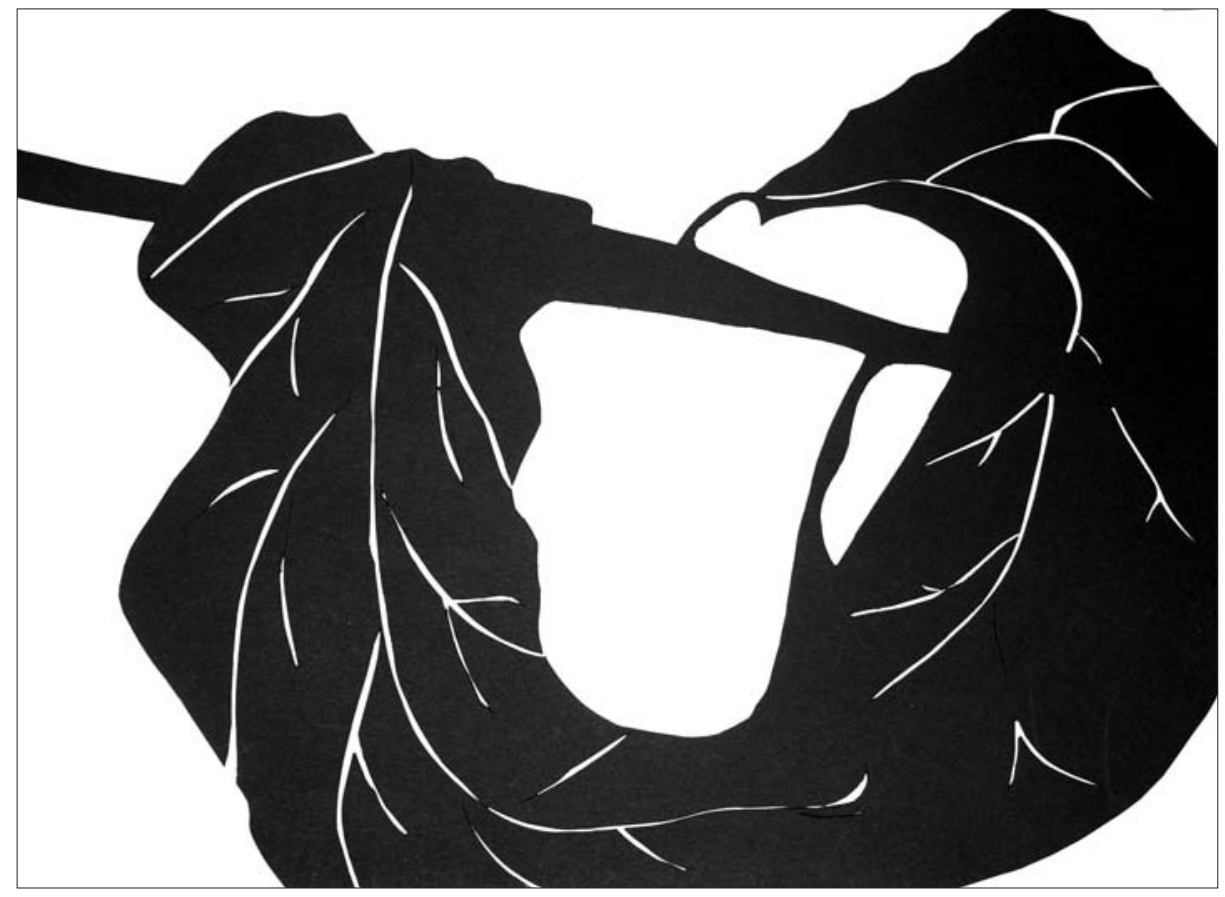

Alexandra Neves 

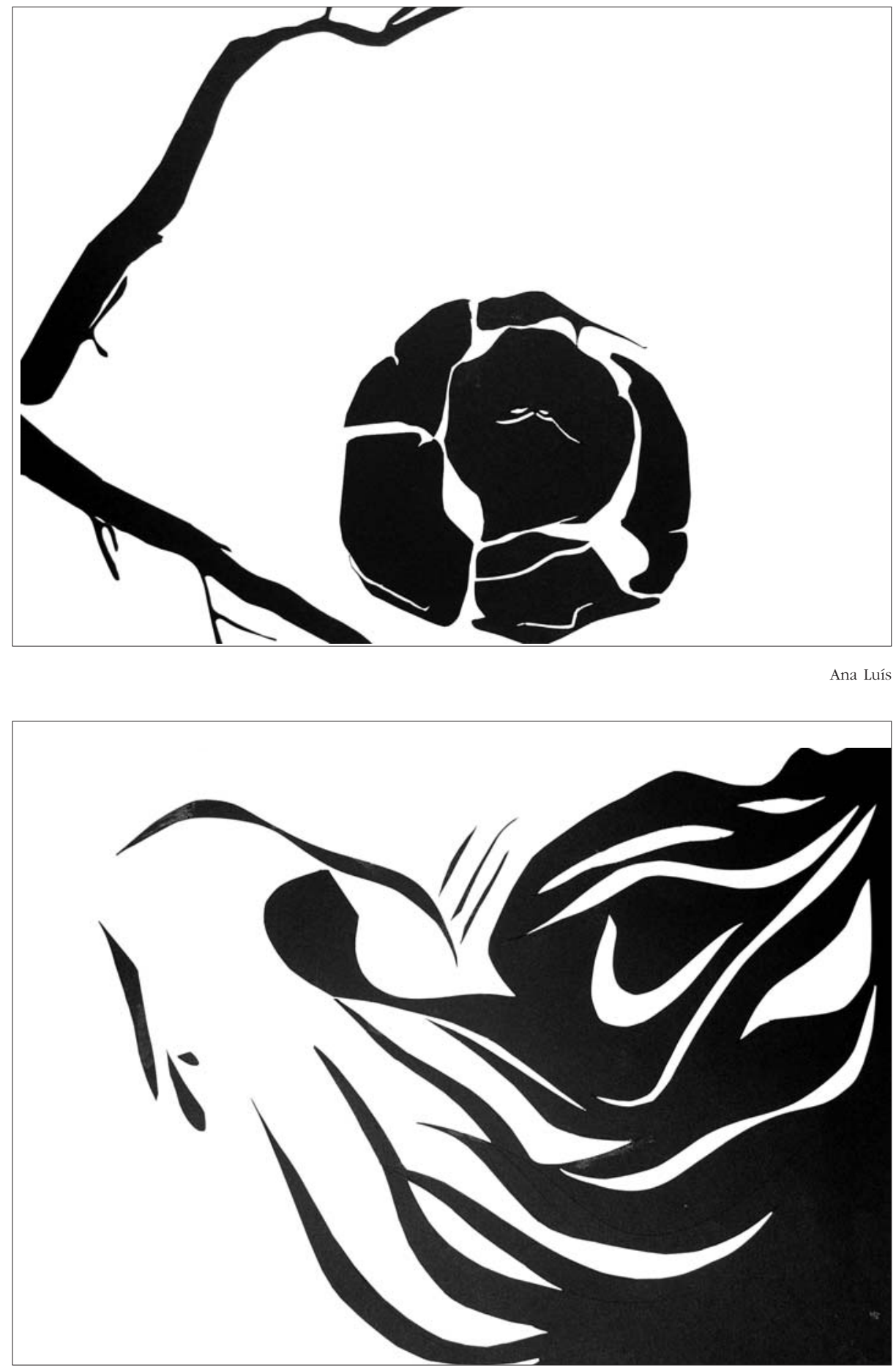

André Vasconcelos 


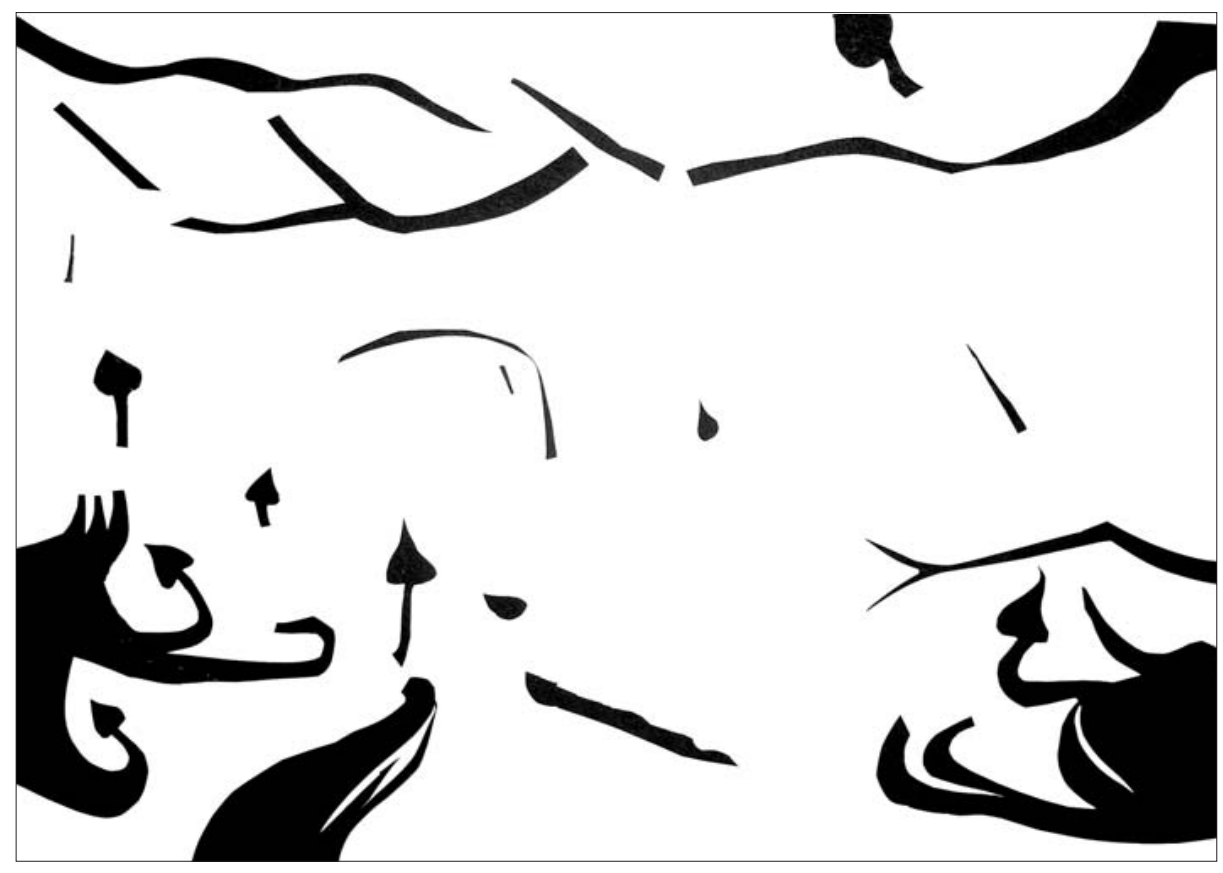

Alexandra Neves

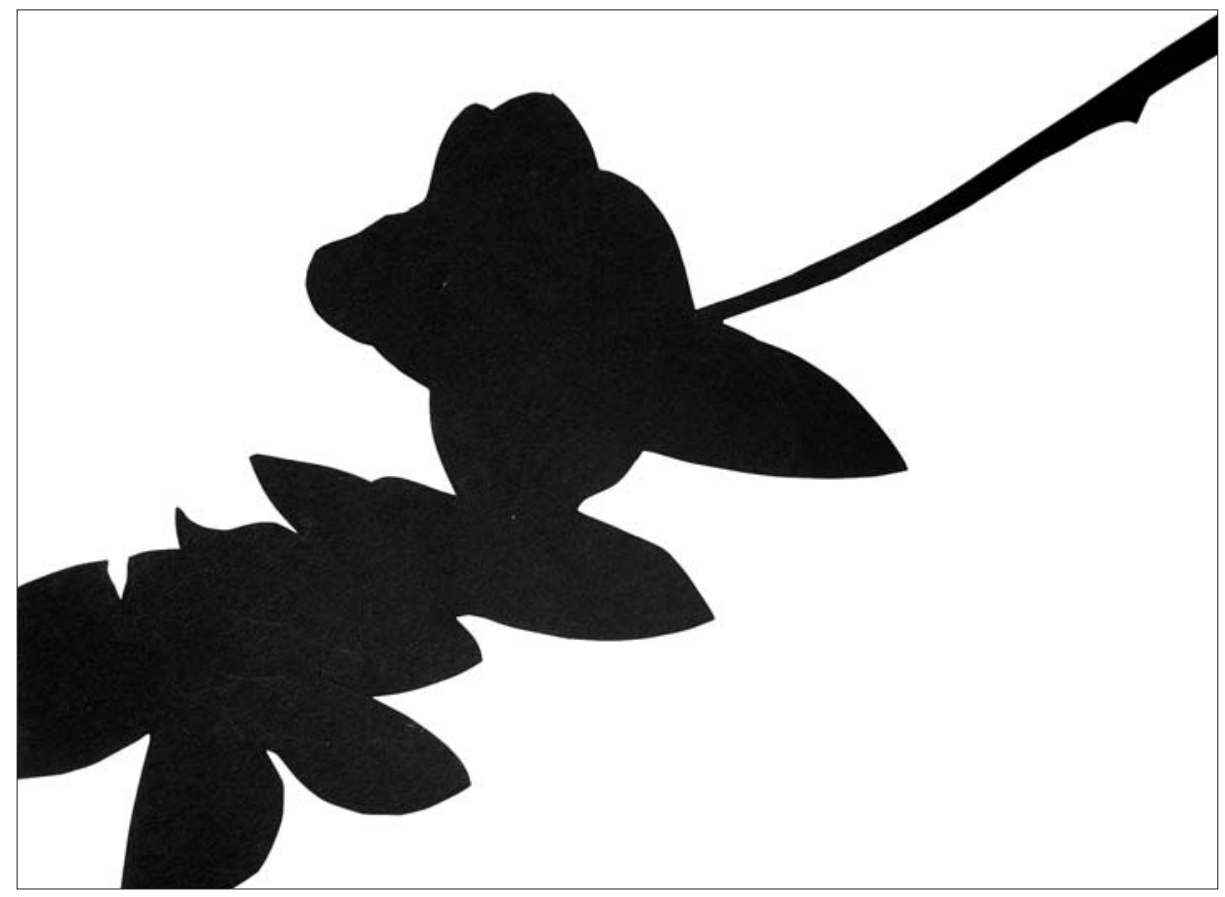

Alexandra Neves 


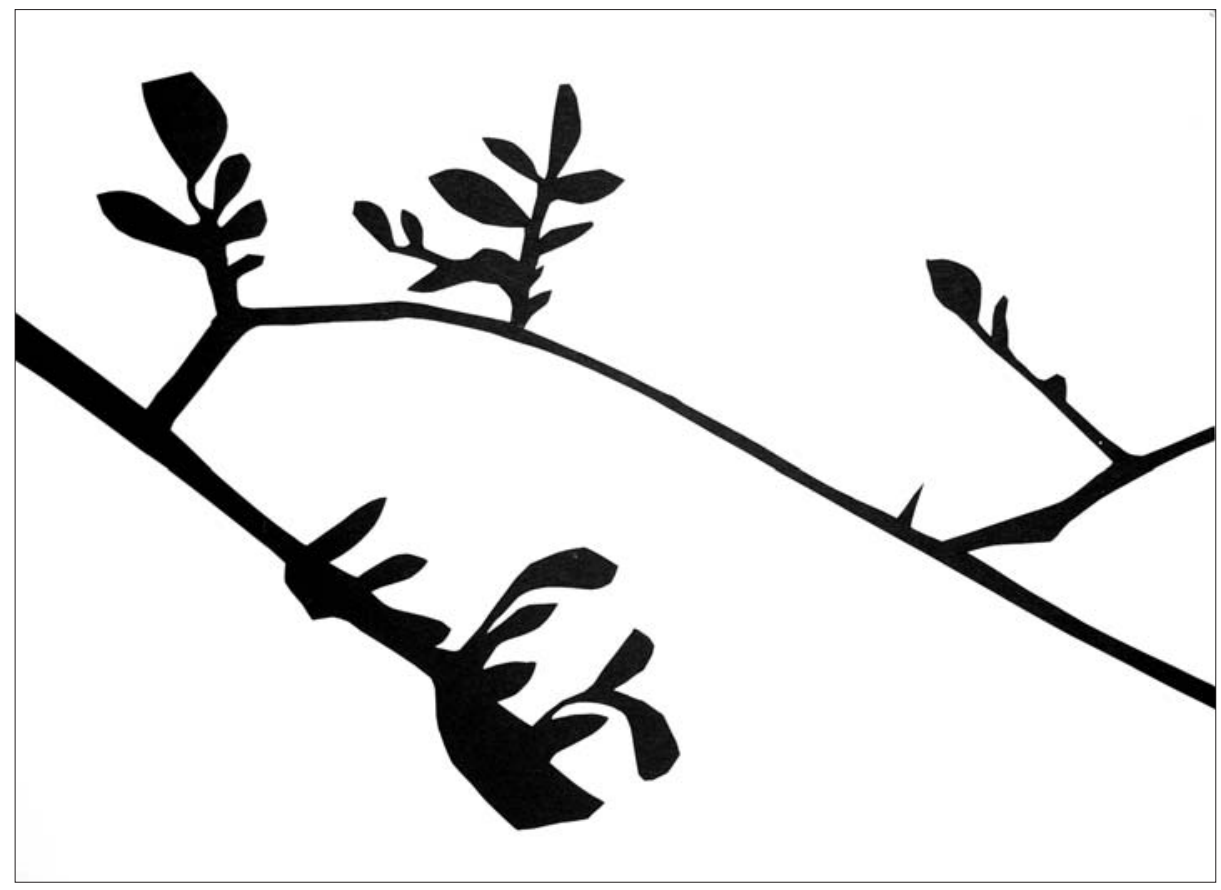

Catarina Garcia

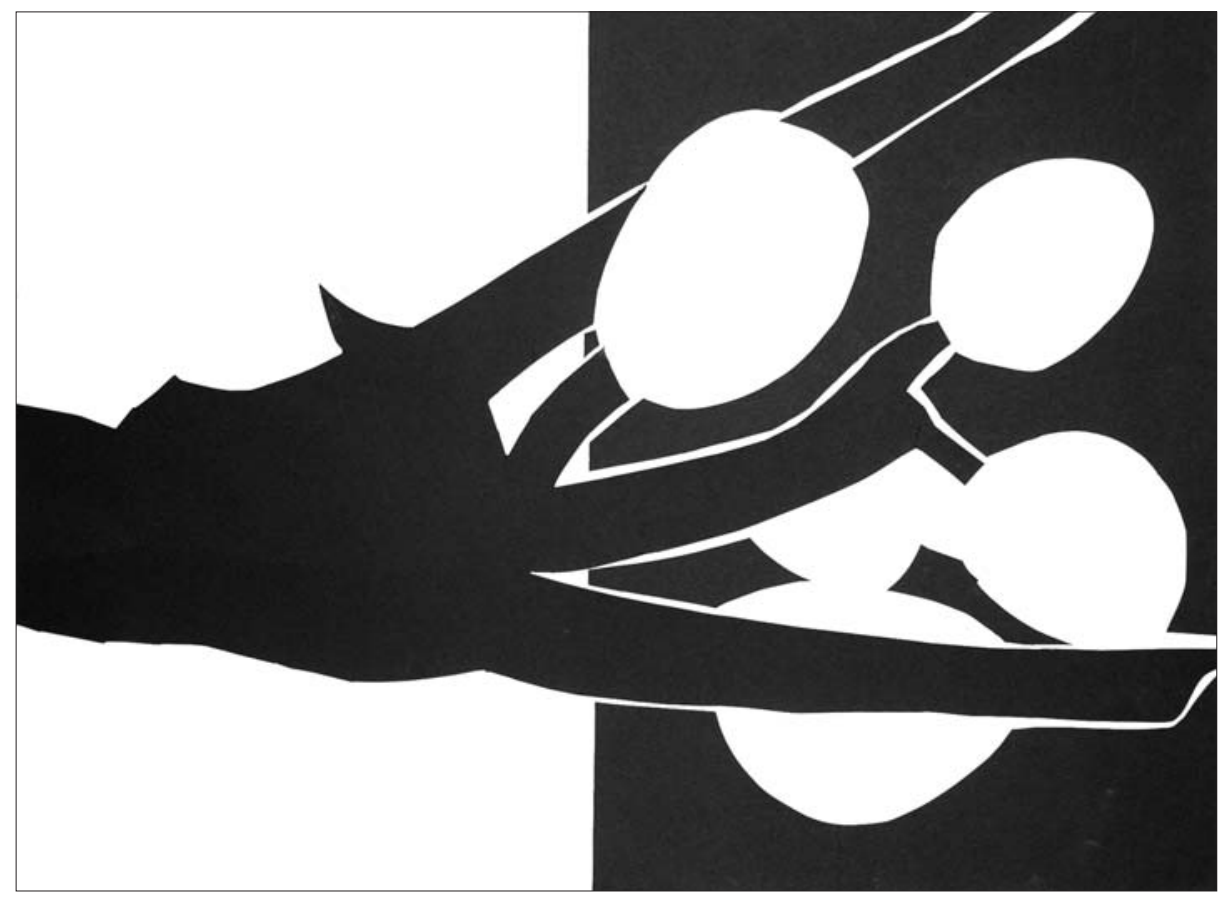

Célia Lopes 


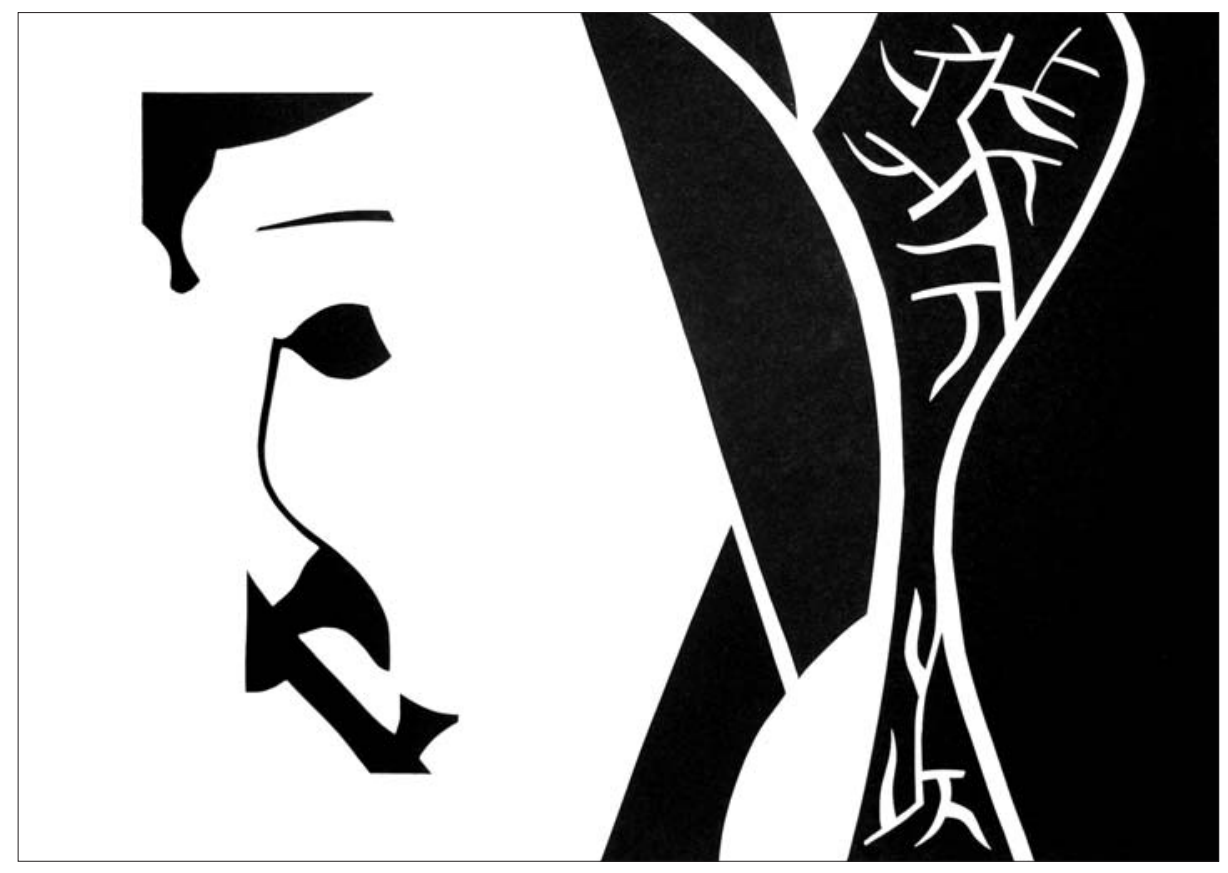

Alexandra Neves

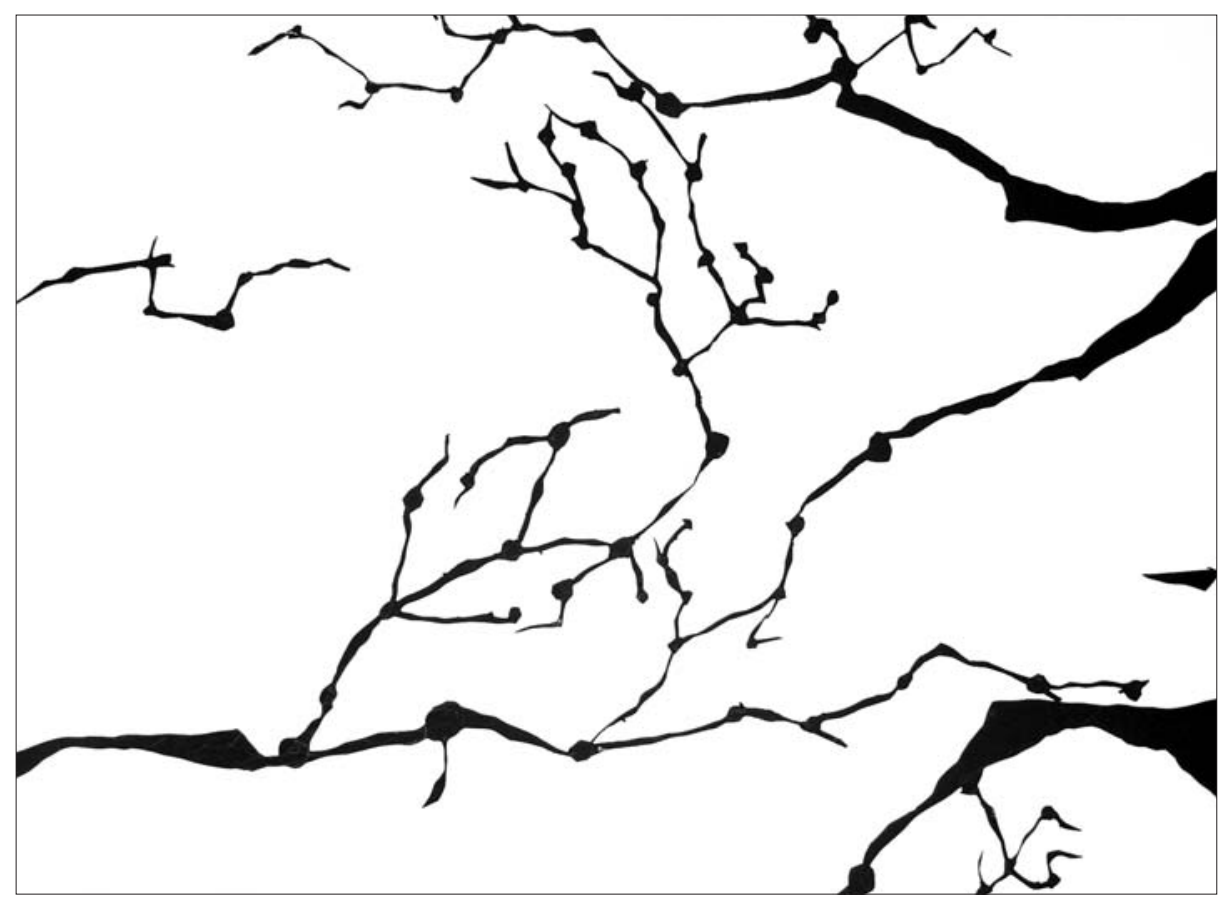



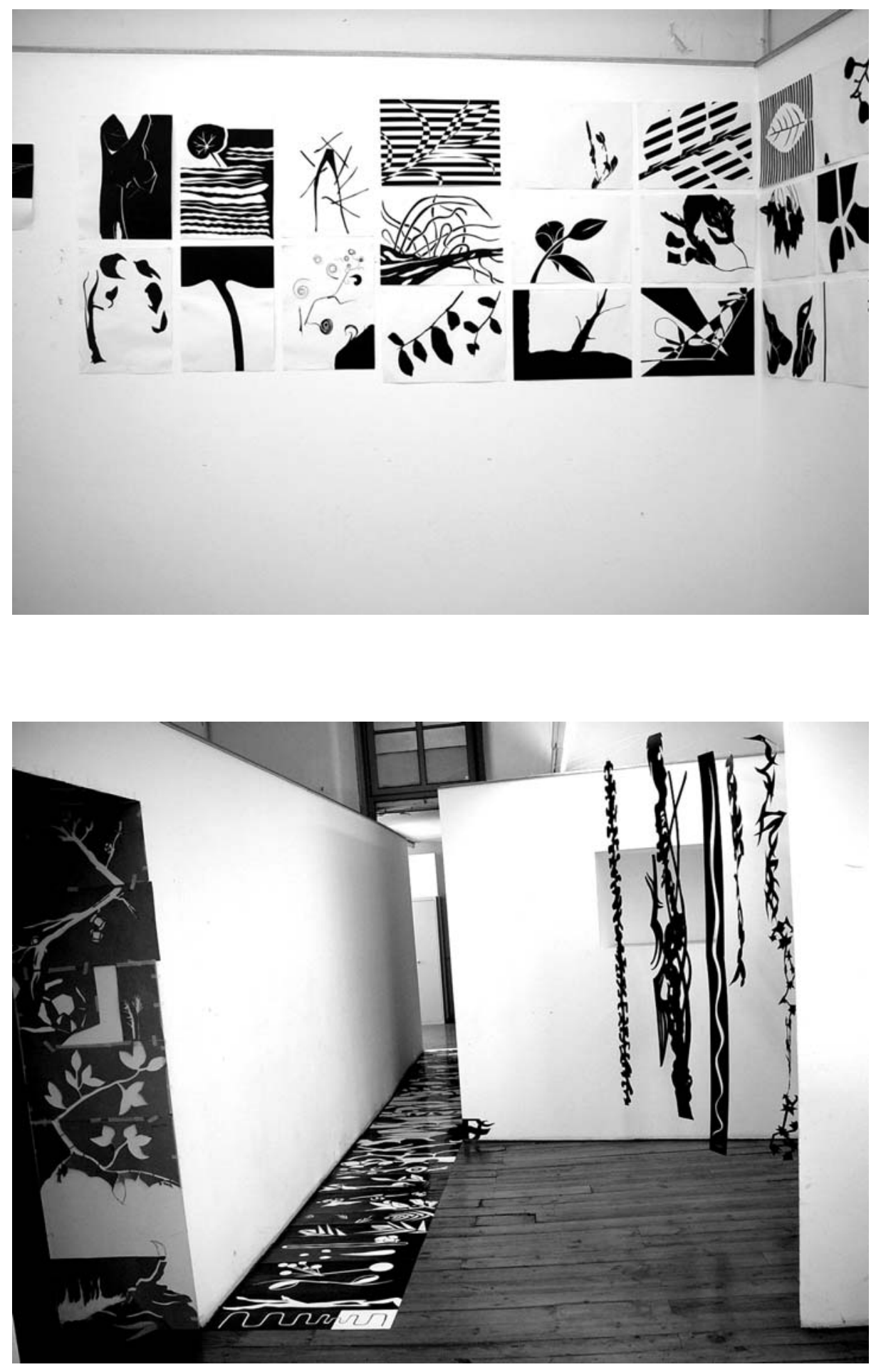


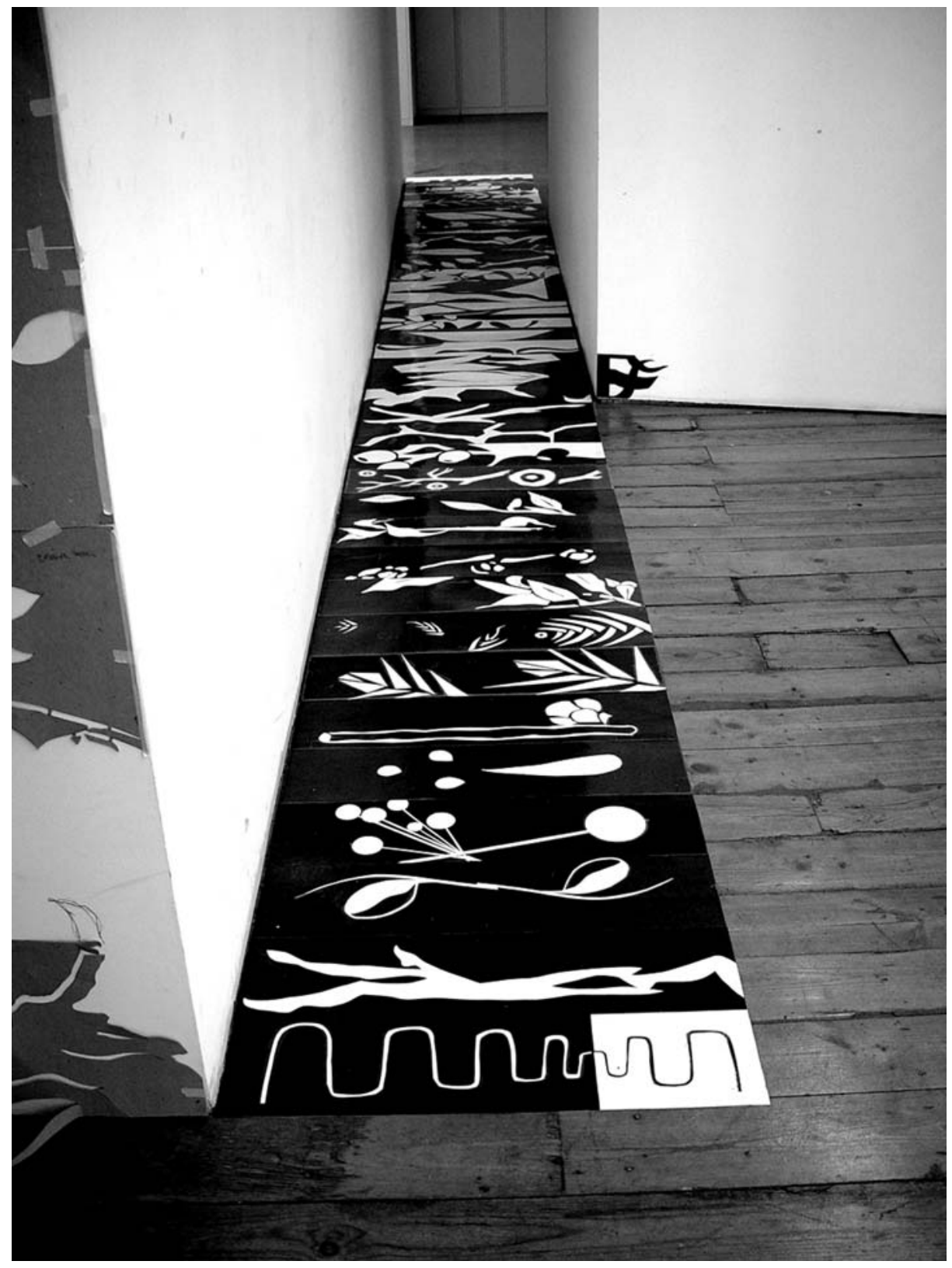




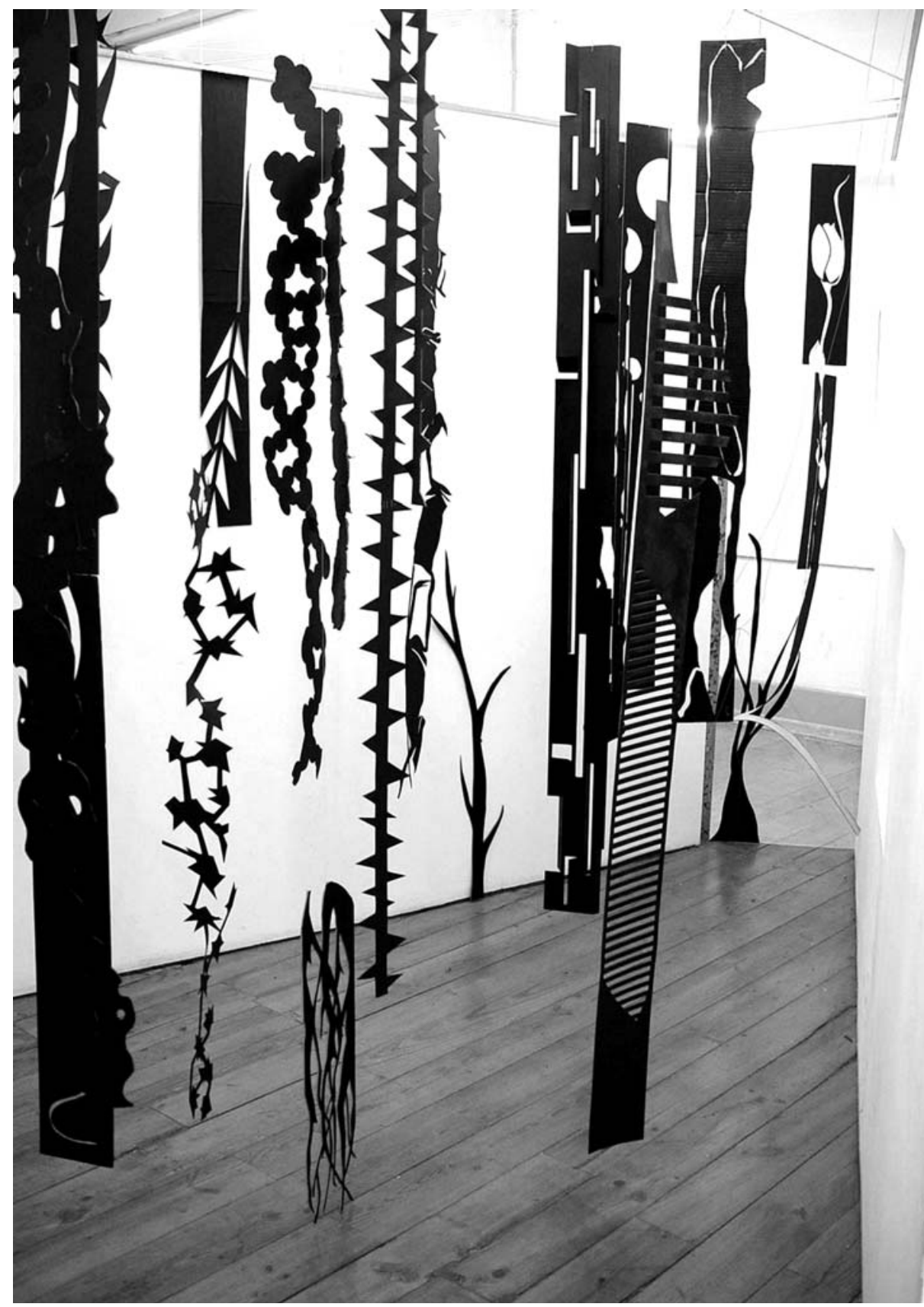



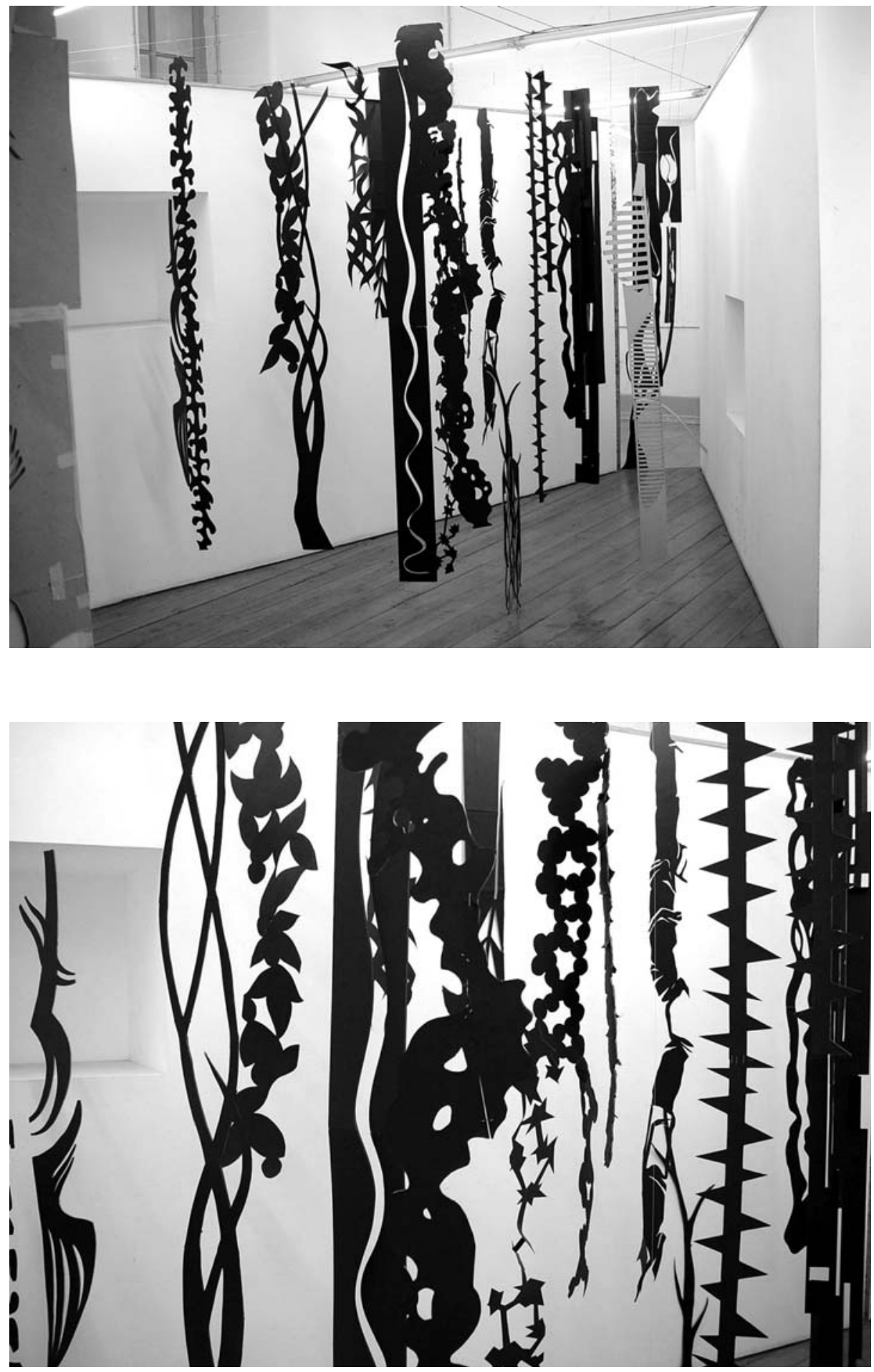
COMPOSIÇÕES TENDO O ROSTO COMO PONTO DE PARTIDA 
(Página deixada propositadamente em branco) 
Variações compositivas a partir do rosto, encarando os elementos do rosto como peças de um jogo num vasto campo de possibilidades plásticas de transformação.

O rosto, assim, é pretexto para a composição.

O rosto, normalmente encarado como imagem de uma identidade é por isso mesmo, o ponto de partida ideal para estes exercícios, onde a transformação contraria a figuração sendo, sobretudo, motivada pela plasticidade, numa atitude de claro distanciamento entre o modelo ponto de partida e pretexto e a autonomia plástica das linhas, das manchas, das formas.

Este exercício, parte das formas de um rosto para a utilização do desenho na valorização dos valores abstractos de uma imagem.

O entendimento deste exercício será tanto maior quanto mais se ultrapassarem atitudes meramente caricaturais para a revelação de uma sensibilidade plástica, na plasticidade da organização das formas, dos gestos no suporte. 
102
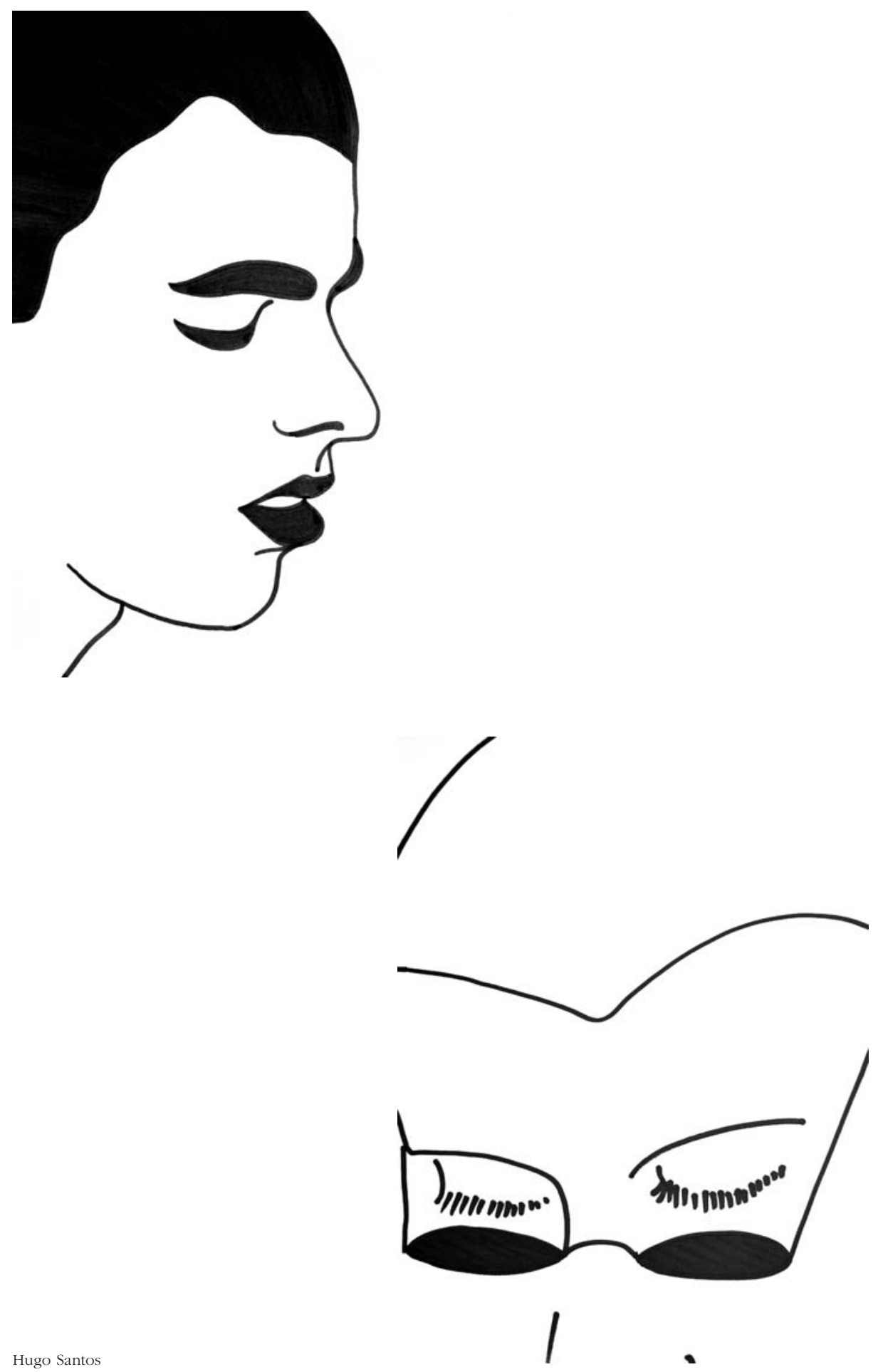

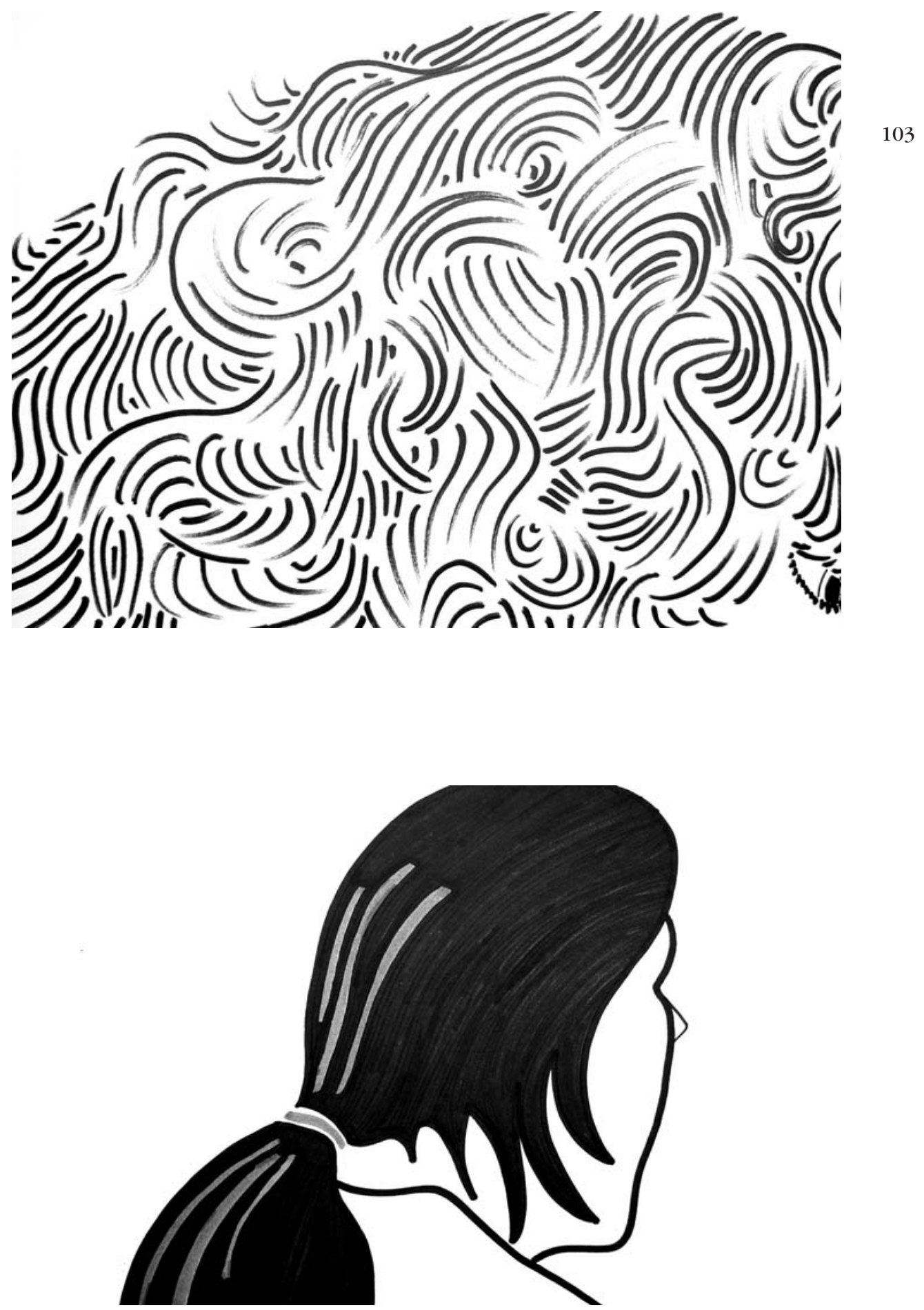


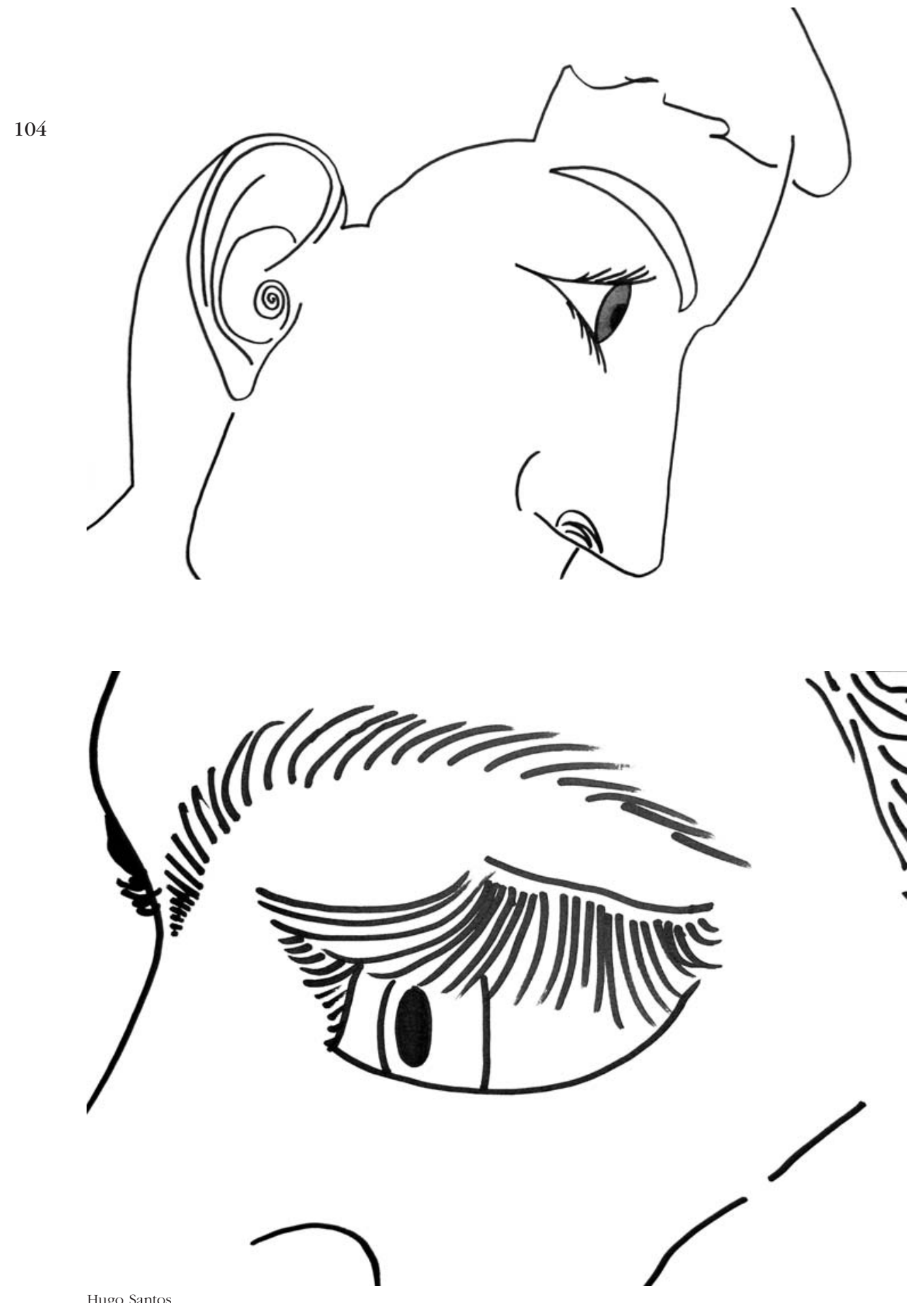



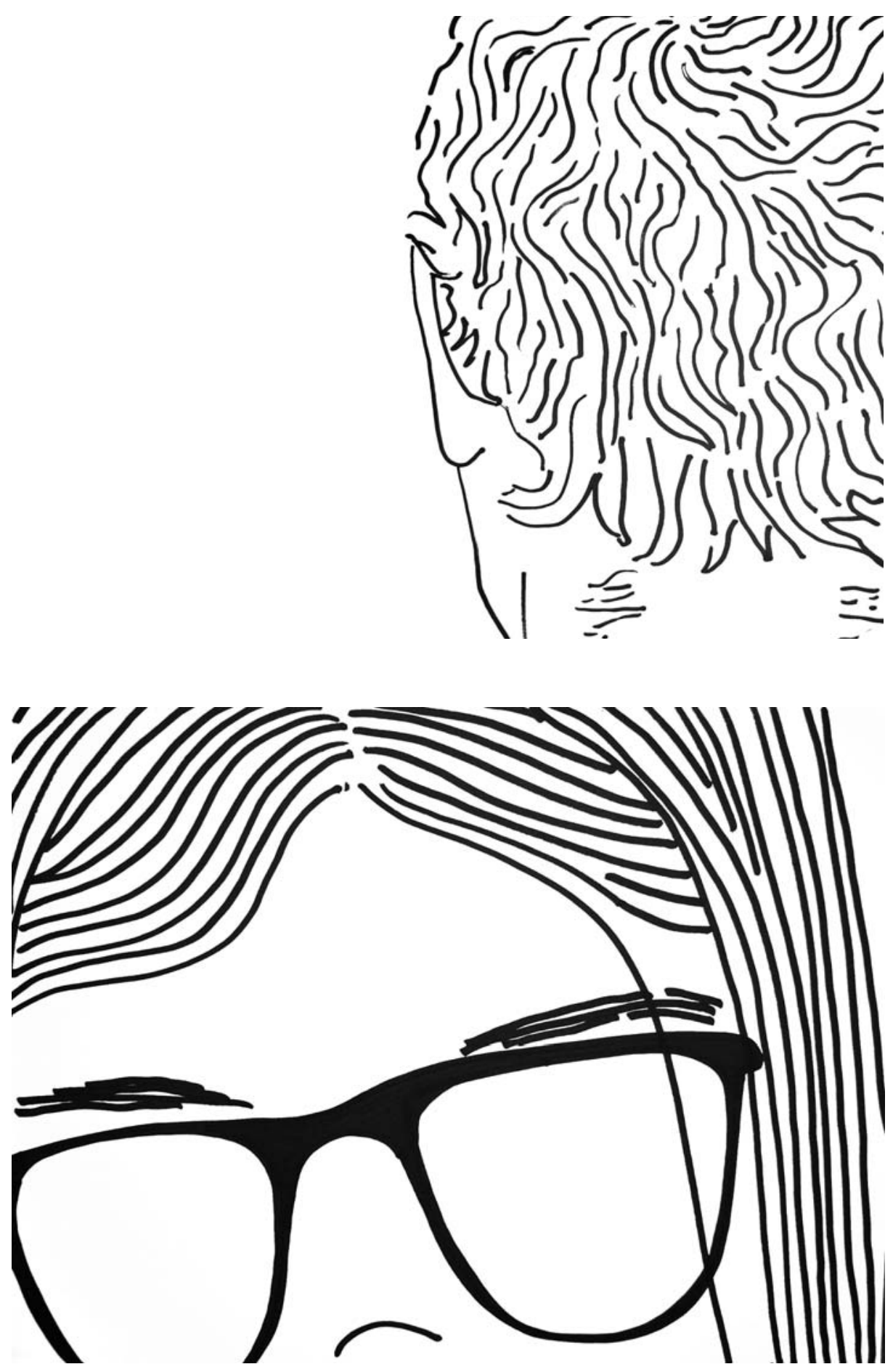
106
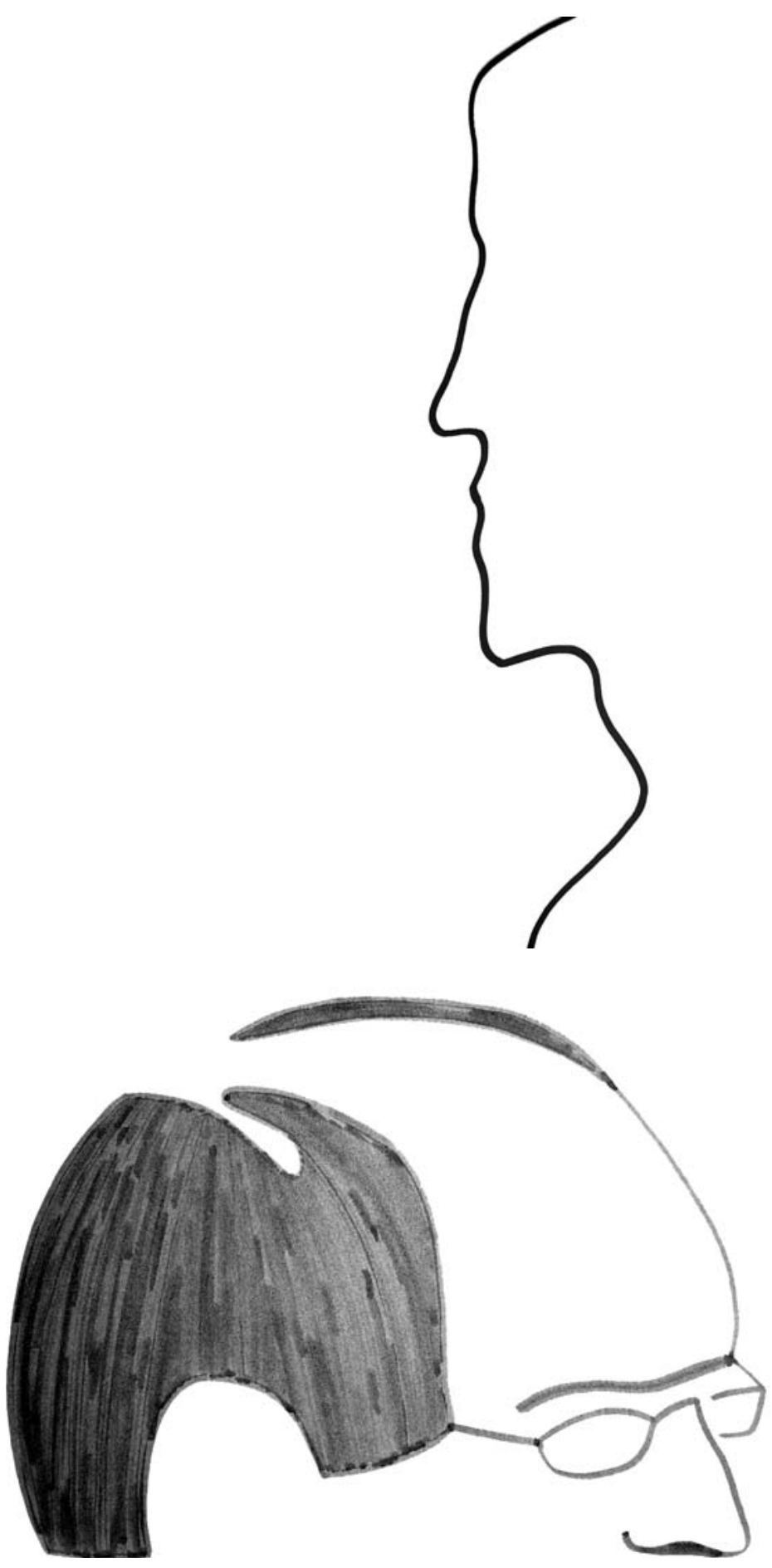

Hugo Santos 


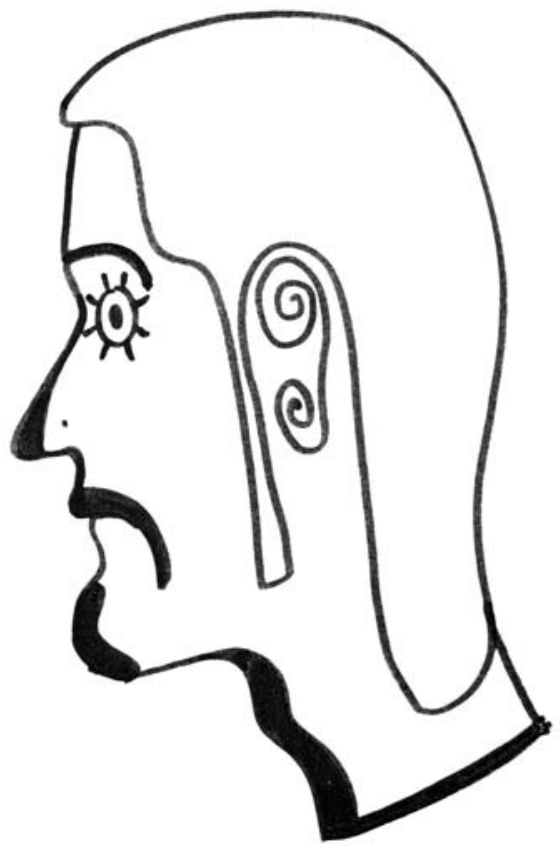

107

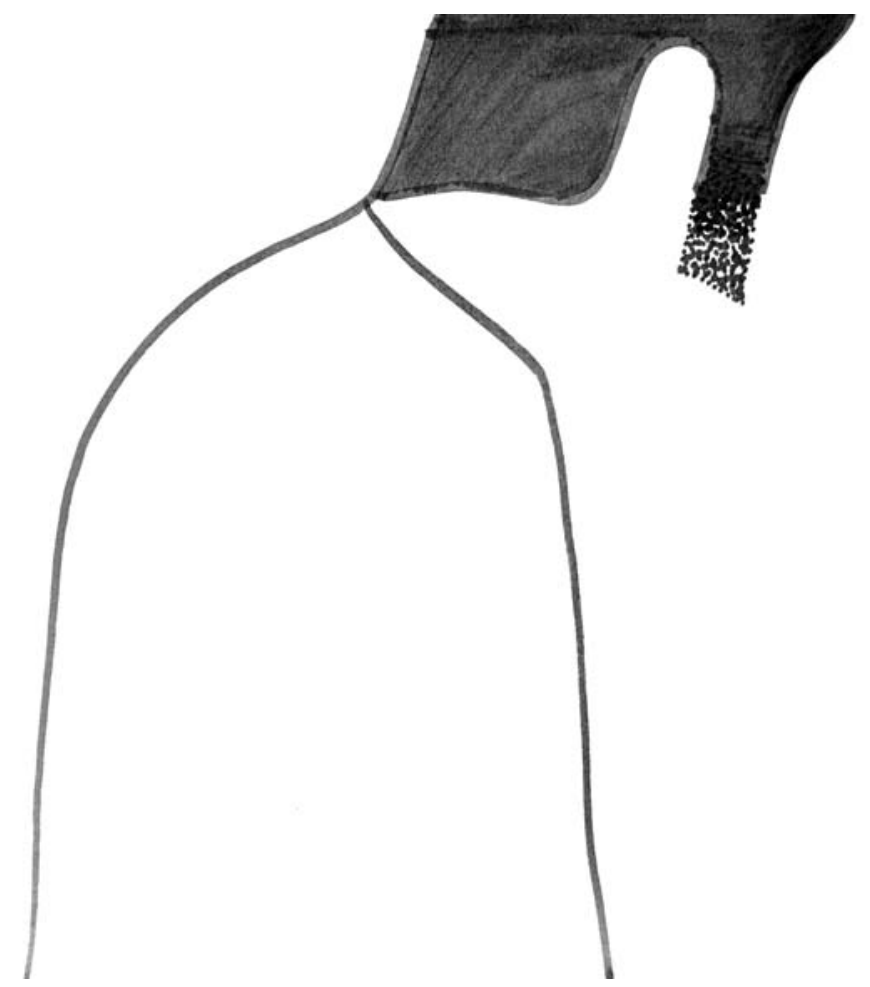


(Página deixada propositadamente em branco) 
O DESENHO MOTIVADO PELO CONCEITO 
(Página deixada propositadamente em branco) 
Desenvolvimento de um exercício, onde todos os alunos têm como ponto de partida um mesmo conceito.

Nos exemplos que aqui ilustramos os alunos partiram da ideia de percurso, passagem de um lugar a outro, proposta motivada por um exercício de Projecto II que consistia no desenhar uma ponte pedonal habitada, entre as duas margens do Mondego. Na ideia de que um percurso não só tem a qualidade de ligar dois lugares como também surge da caracterização do caminho entre um lugar e outro, chamámos a este exercício, como motivação conceptual para os desenhos: Caminho e atalbos. 


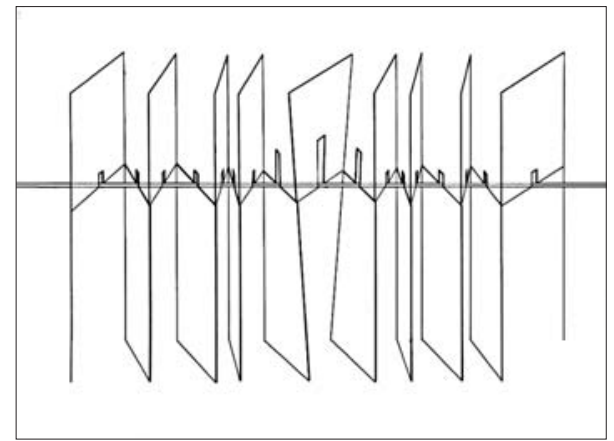

Miguel Amado

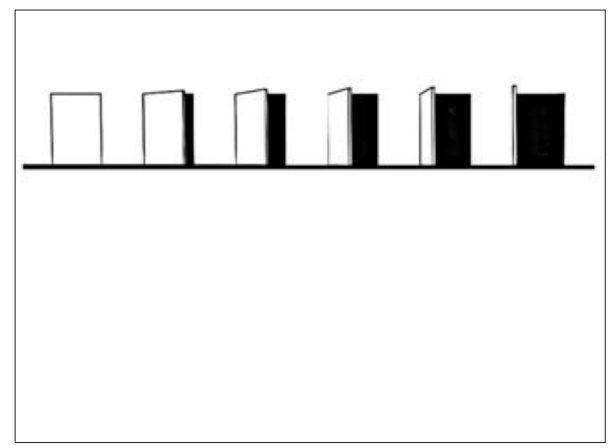

Hugo Moura

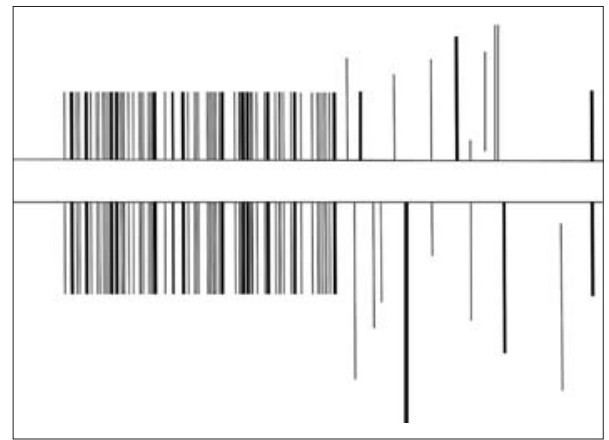

Mafalda Oliveira

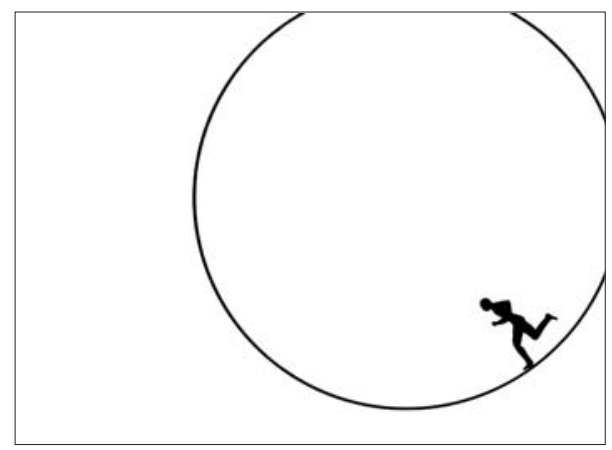

Joana Couceiro
A sugestão de um percurso desenhado pela arquitectura,

na elementaridade da linha, movimento de uma estrutura imponderável que se contrai e expande.

Sucessão de momentos de uma porta que se abre.

Percurso temporal, na simultaneidade dos vários instantes.

Percurso que atravessa um código de barras, dissolvendo-o.

Dissolução de uma identidade ou somente da sua catalogação?

Percurso circular, sem qualquer objectivo que não seja o de percorrer.

Ou homem como um hamster em ilusão de fuga? 
Contraste entre a acidentalidade orgânica e a racionalidade de um caminho na distância mais curta entre dois pontos.

Circuitos de um dispositivo electrónico. Combinação de circuitos numa inteligência artificial.

Percurso da sucessão das letras, da sucessão das palavras.

A ampliação das escalas sugere a possibilidade de opção por multiplos caminhos.

Pontuação de um percurso. Quebra da regularidade rítmica, pela pausa.

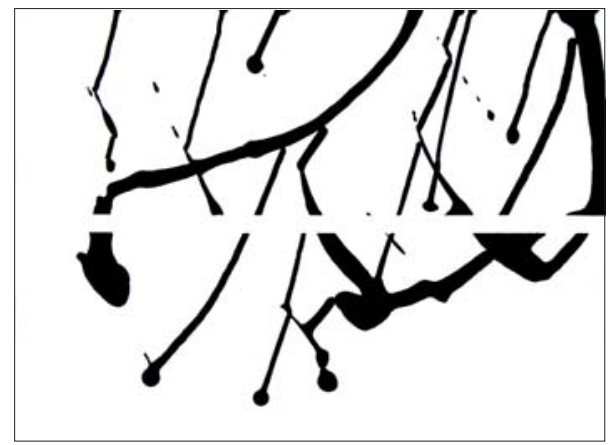

Pedro Baía

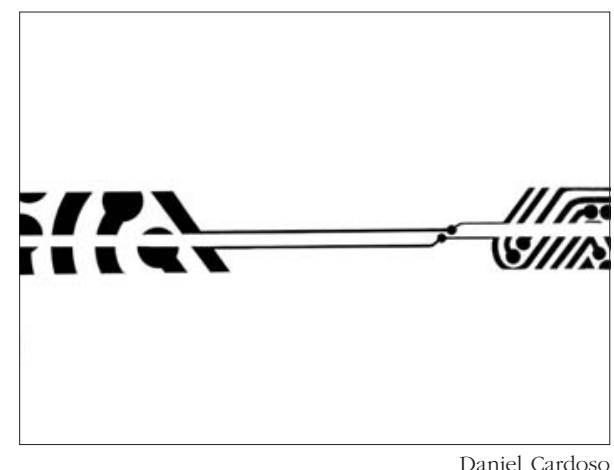

Daniel Cardoso

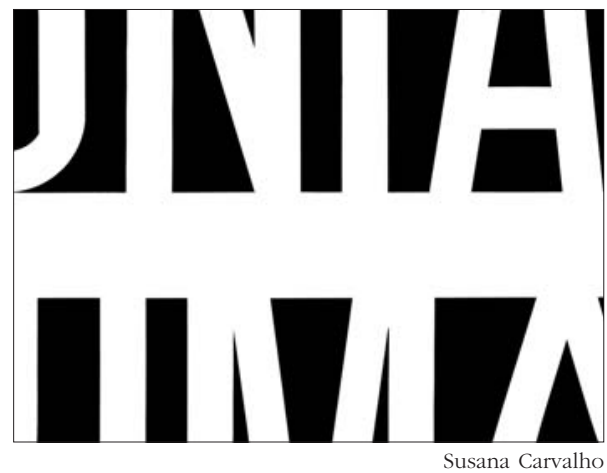

Susana Carvalho

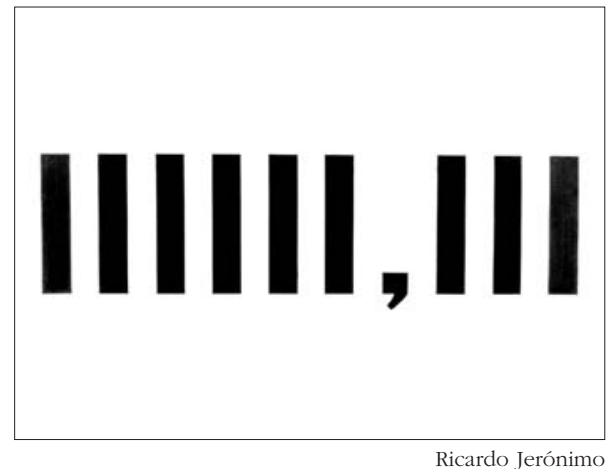


114

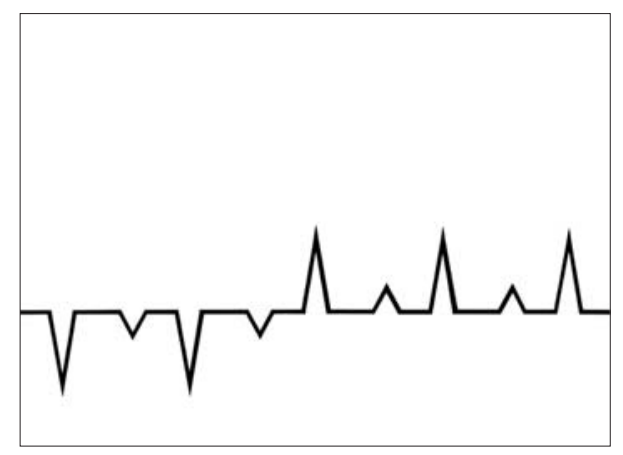

Sidney Melício

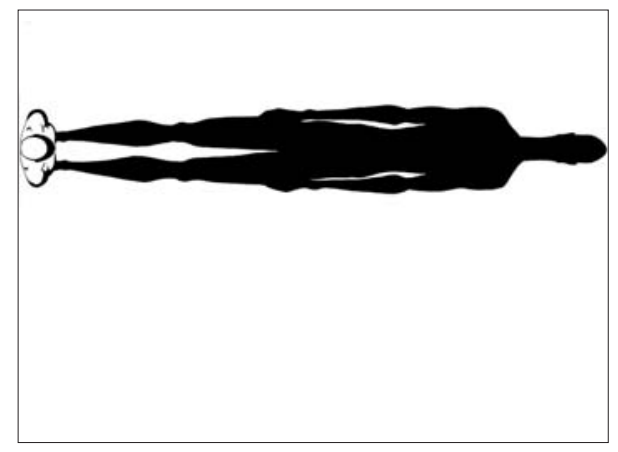

Nelson Mestre

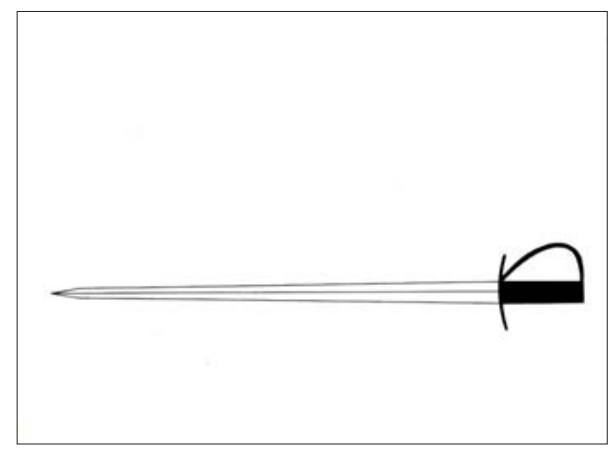

Margarida Relvão

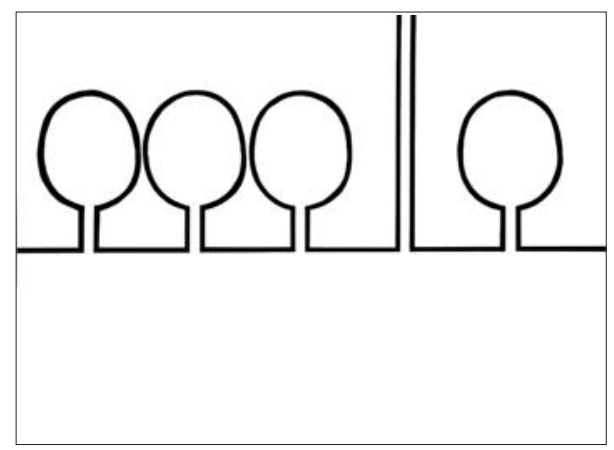

Estilização de um electrocardiograma. Aqui, a vitalidade contraria a linearidade. Um percurso na distância mais curta entre dois pontos seria fatal.

O percuso, sendo a sua sombra, é o próprio indivíduo.

A escala transforma um objecto em percurso.

E a natureza deste objecto traduz um vector, na veemência de um punhal.

Excepção num percurso cuja regularidade rítmica é acentuada pelo paradoxo de árvores como logotipos. 
Percurso num universo de símbolos, onde os sinais substituem os seres e as coisas.

Perturbação óptica na homogeneidade de um percurso. Percurso objectivamente homogéneo, subjectivamente variável.

Corte violento de um percurso. Violência maximizada pela sugestão de um percurso como coisa orgânica.

Falso labirinto, na evidência de uma solução que torna todos os caminhos opcionais puramente decorativos.
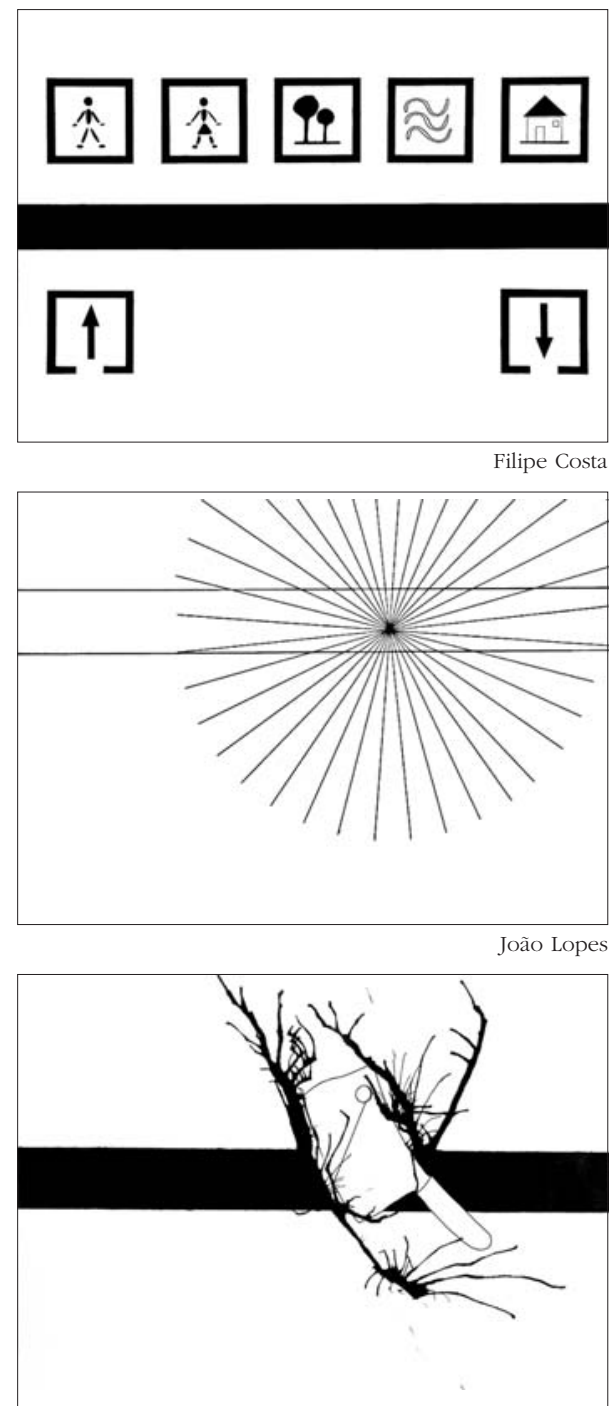

Branca Pegado

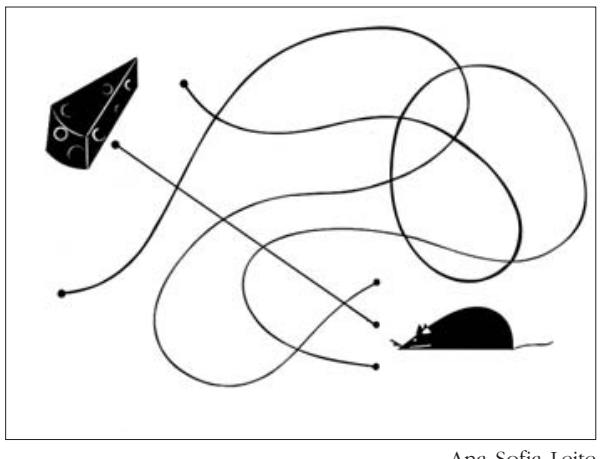

Ana Sofia Leite 


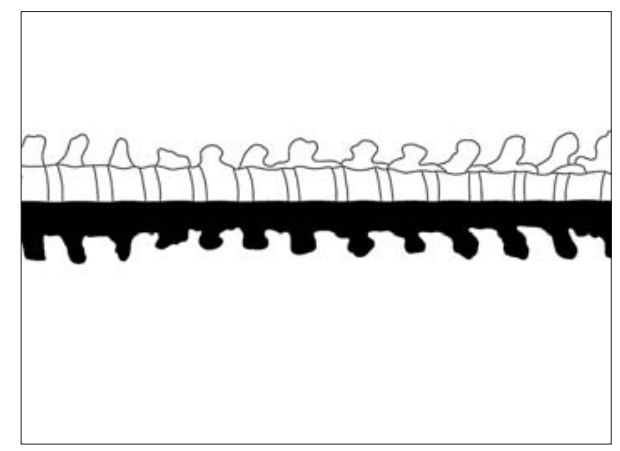

Ana Grácio

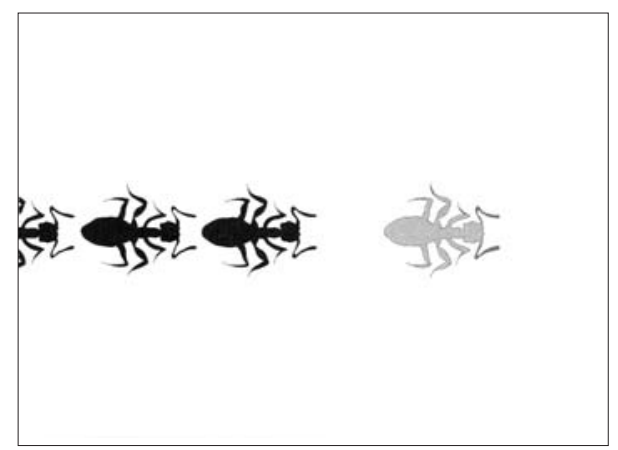

Carla Gomes

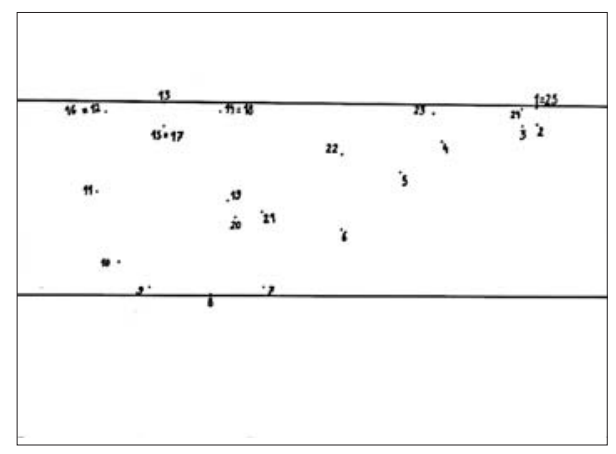

Mafalda Oliveira

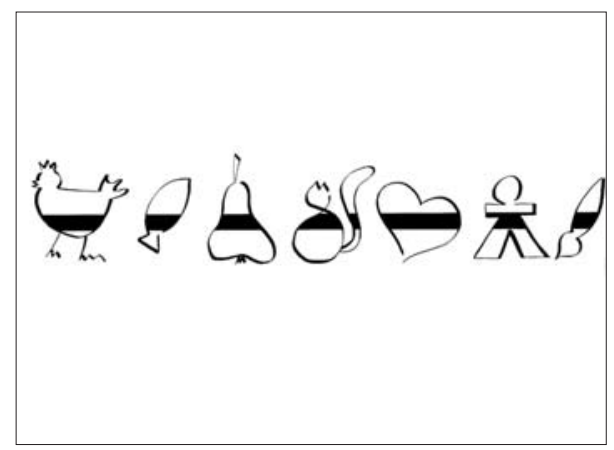

Vera Pinto
Um percurso estrutural, como uma coluna vertebral.

A formiga que vai à frente cria o percurso, como o primeiro ponto de uma linha.

Só percorrendo o caminho se obtém o sua forma.

Unindo os pontos, o desenho de um cachimbo.

Citação de Magritte, na distância entre os significados e a experiência significante.

Caminho criado por uma sucessão de coisas.

Continuidade de um percurso, na descontinuidade de um somatório. 
Dissolução de um percurso para um campo de multiplas direcções.

Caminho/ponte, na relação e contaminação entre duas margens.

Caminho que cresce como um dominó. Cada peça, cada secção determina quais poderão ser as próximas. Cada momento do percurso condiciona a sua evolução.

Ponto final de um caminho. Ponto como meta que gera o próprio percurso.

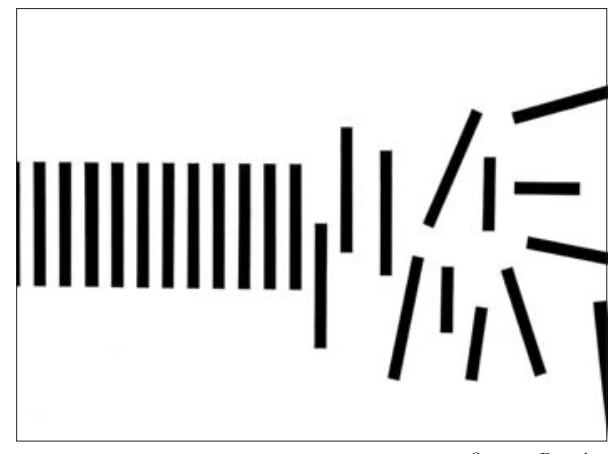

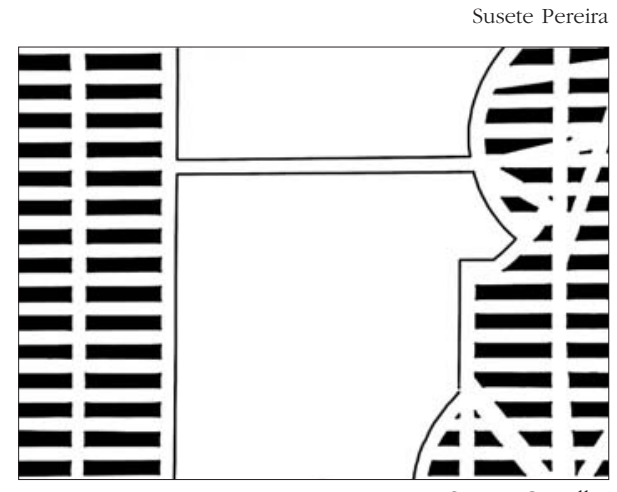

Susana Carvalho

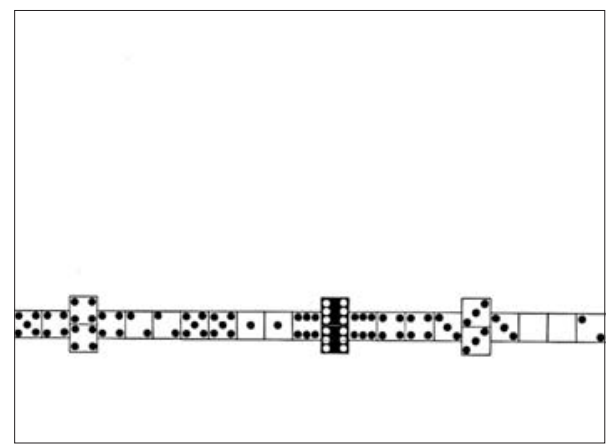

Salomé Galamba

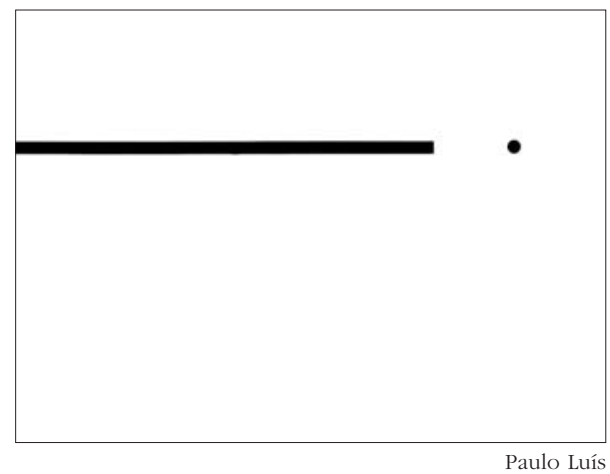


(Página deixada propositadamente em branco) 
DA REPRESENTAÇÃO

À DESCONSTRUÇÃO DAS FORMAS 
(Página deixada propositadamente em branco) 
Representação do esqueleto humano. Análise das suas relações estruturais, na percepção das partes na mecânica do todo.

Criação de composições, tendo como ponto de partida as representações do esqueleto.

As características do objecto da representação motivam composições onde, para além a plasticidade das relações formais, se exploram potencialidades conceptuais, nas relações entre o orgânico e o mecânico, nas ambiguidades das escalas, na possibilidade de múltiplas combinações construtivas.

Os trabalhos resultantes deste exercício resultaram numa exposição (Primavera de 2001) cujo título: A capela dos ossos, ou se os ossos fossem Lego, foi motivado pela relação entre estas derivas da ideia de esqueleto humano e a presença imanente das preocupações da arquitectura. 
122

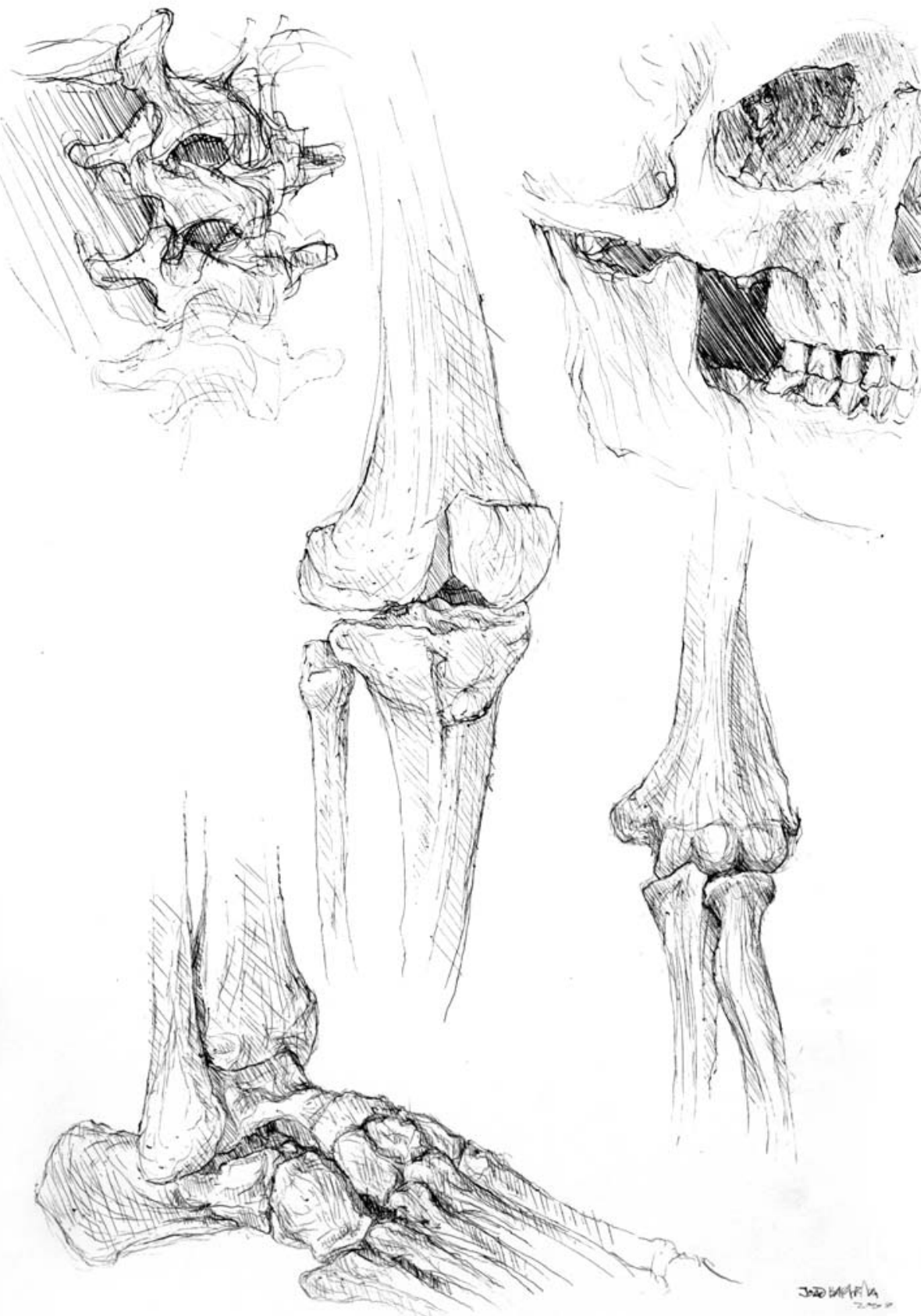



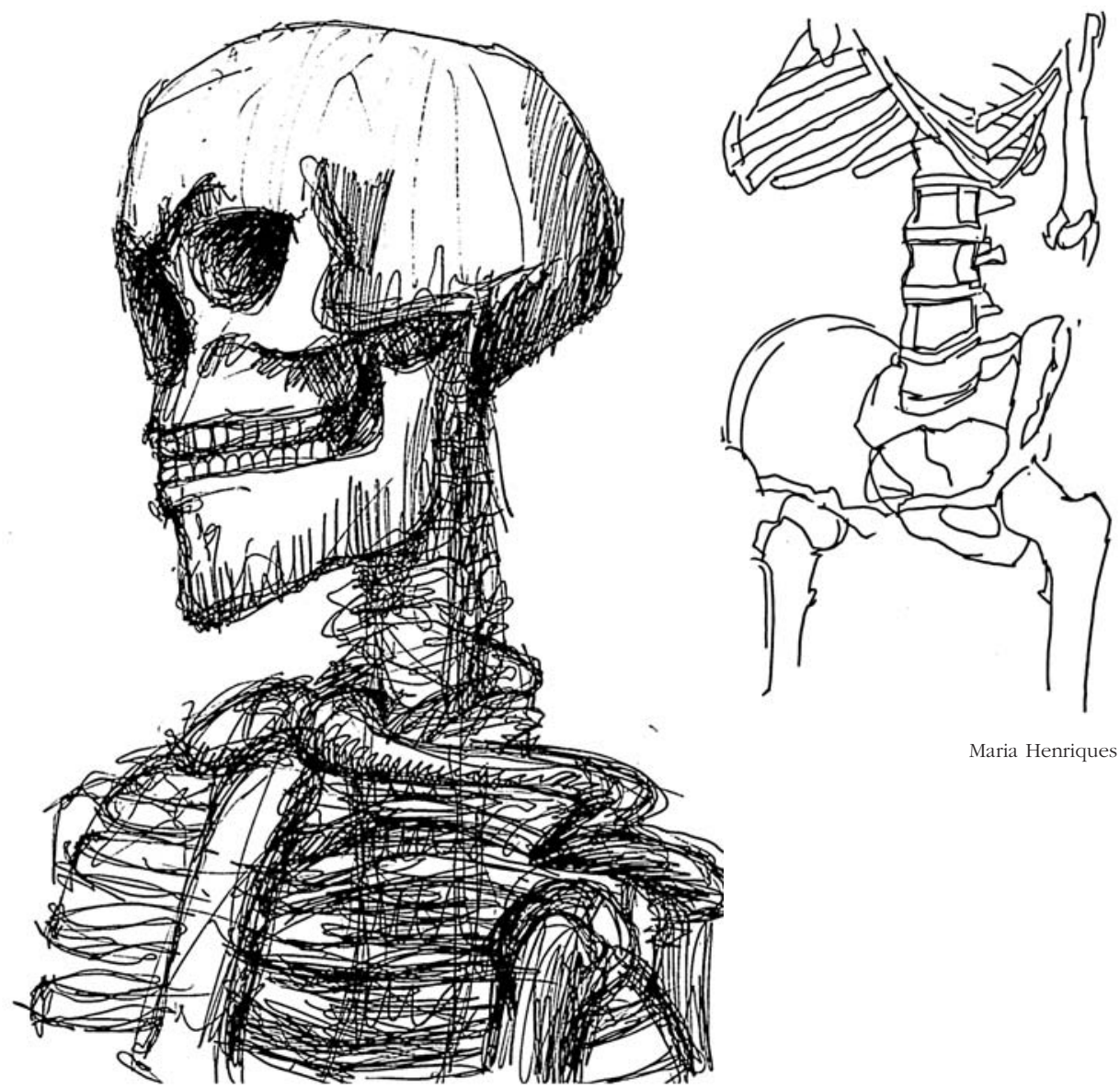

Tiago Fiadeiro

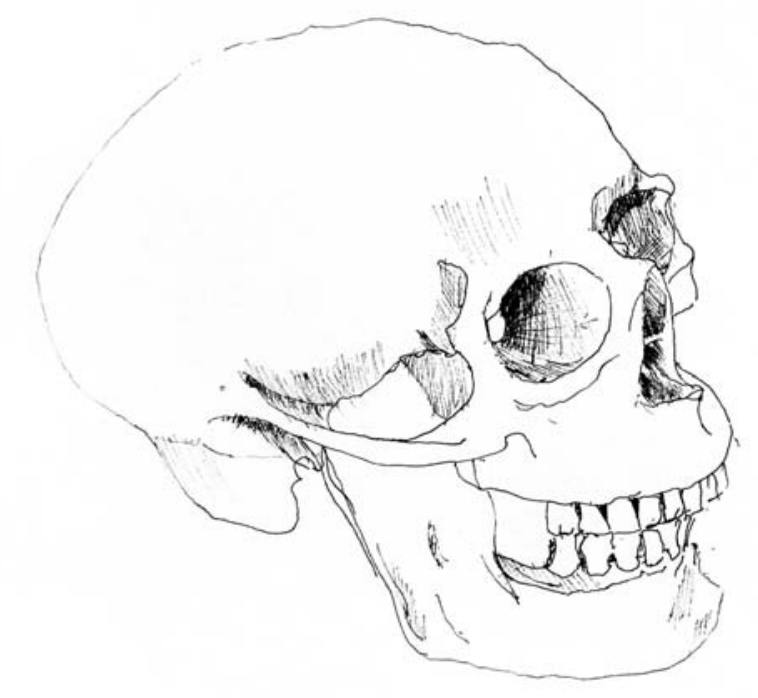

Maria Henriques 

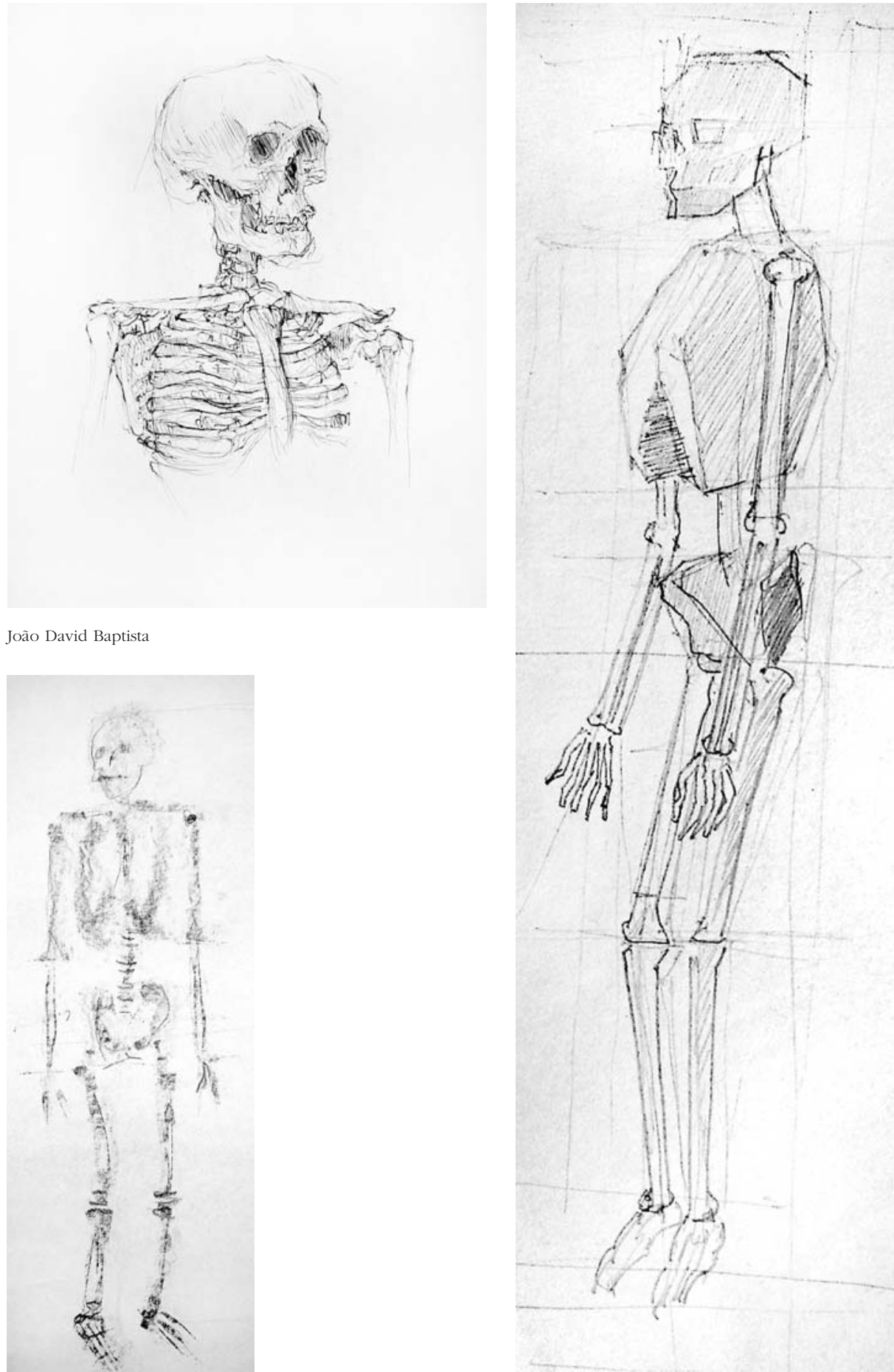

Catarina Morgado

João Santos 


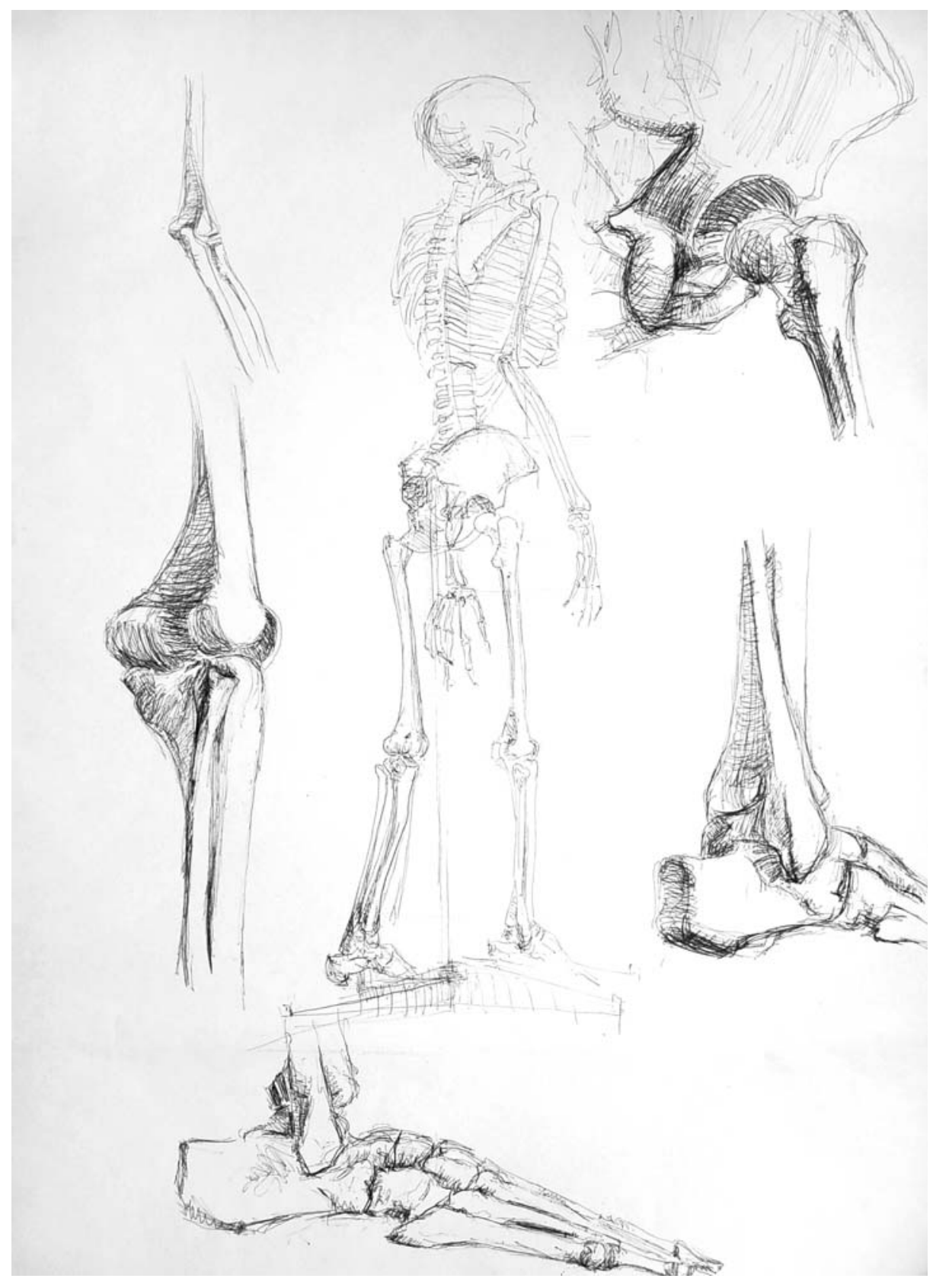

Bruno Gil 


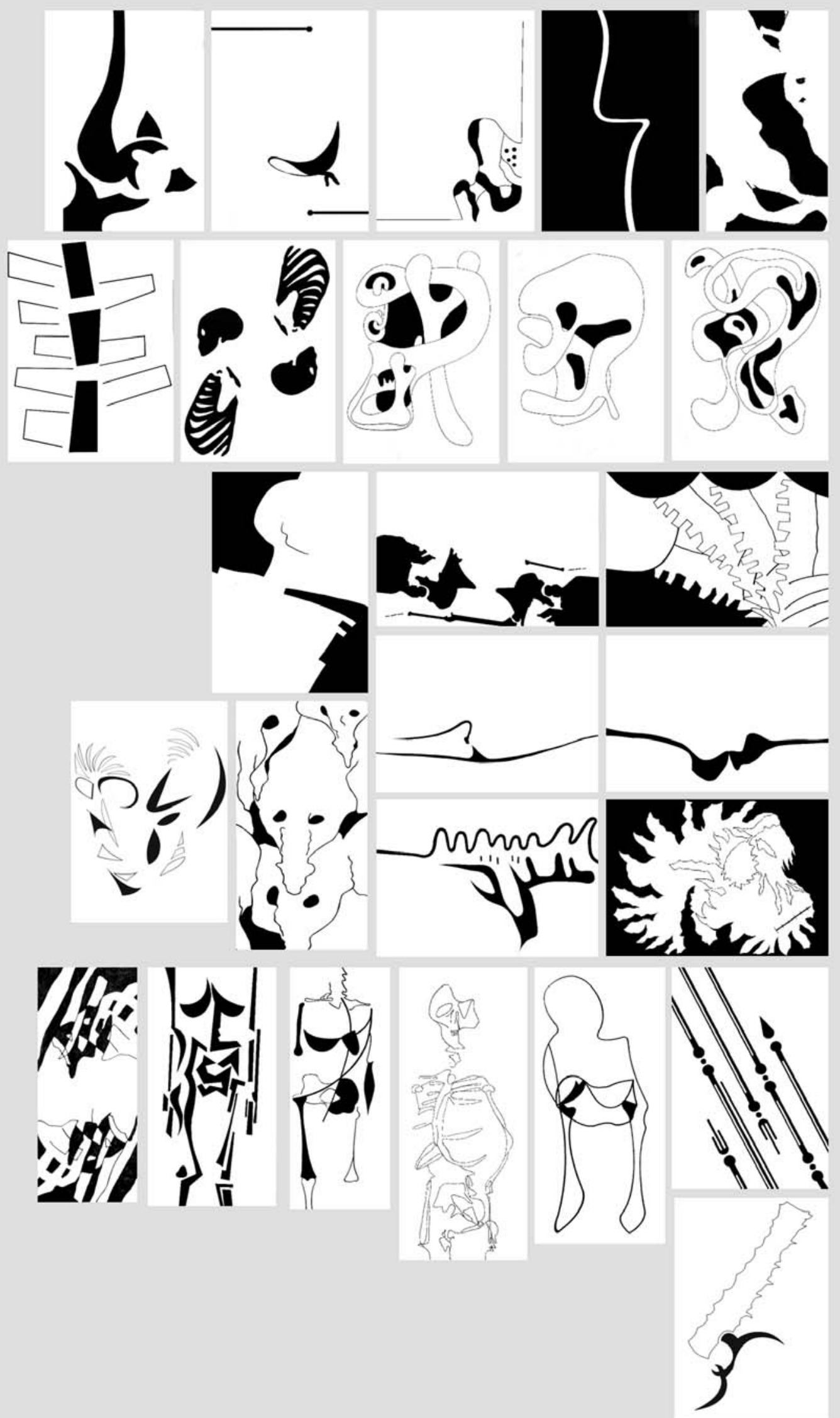



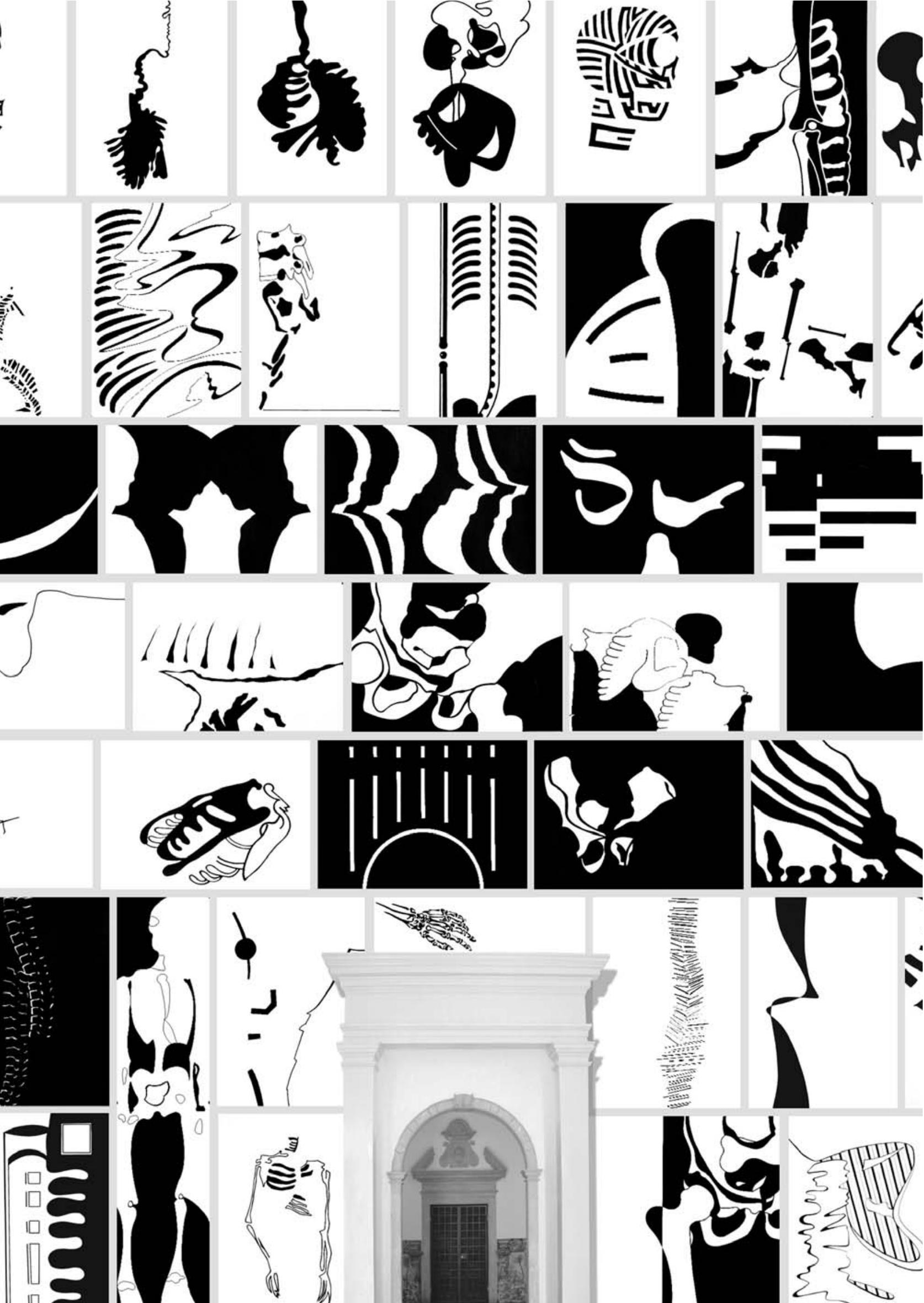


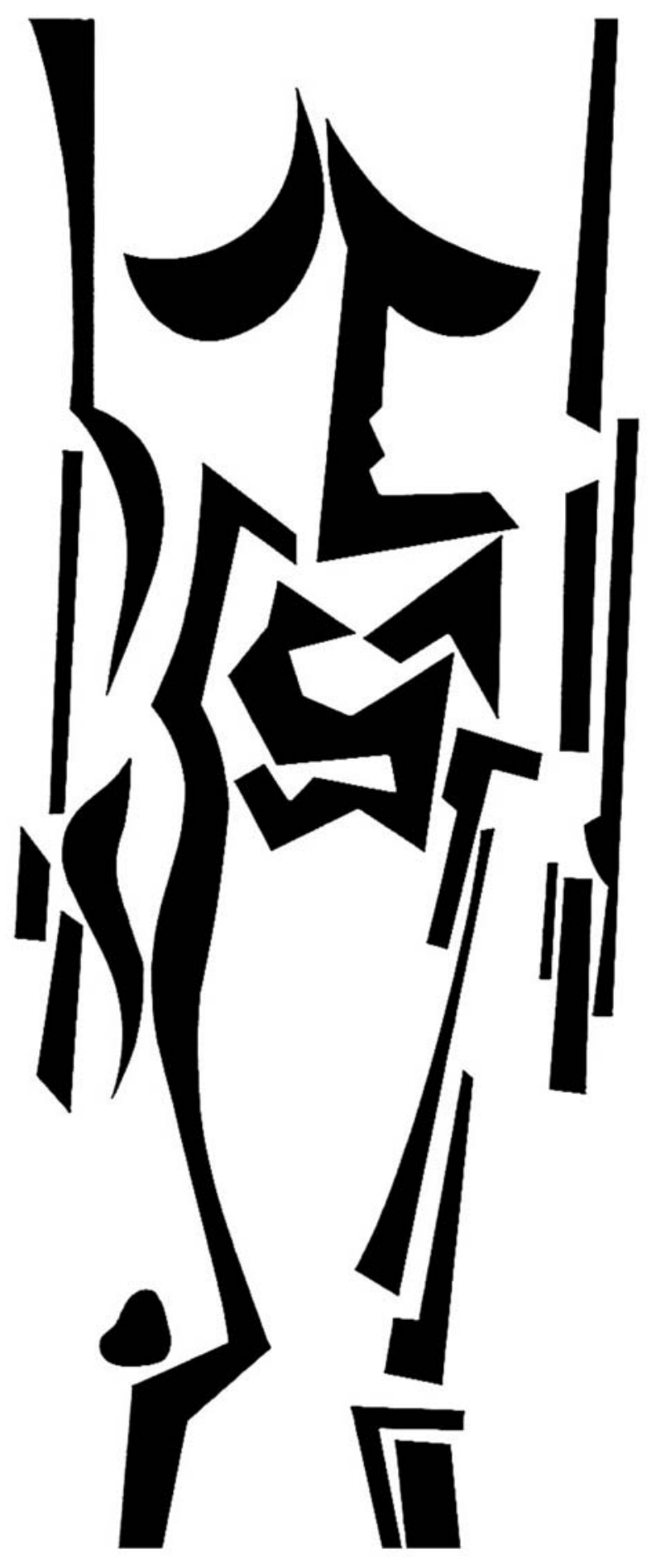



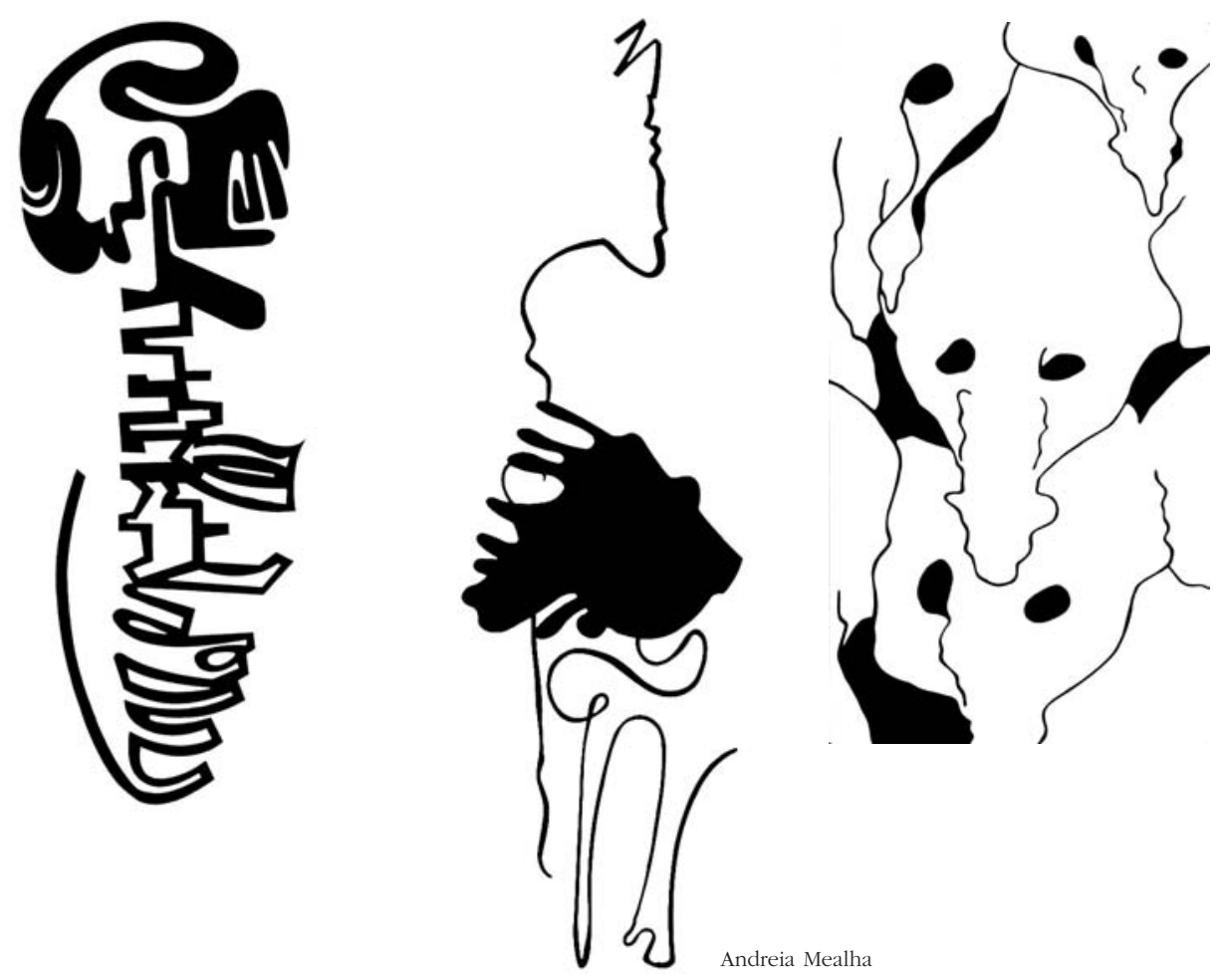

129
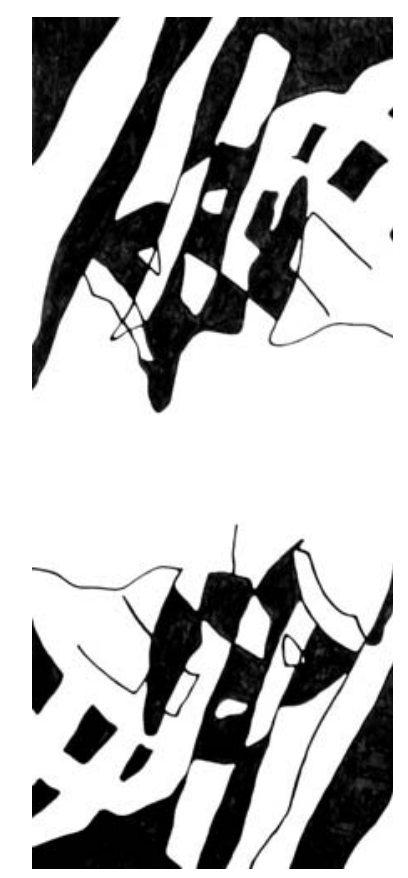

Ângelo Lopes

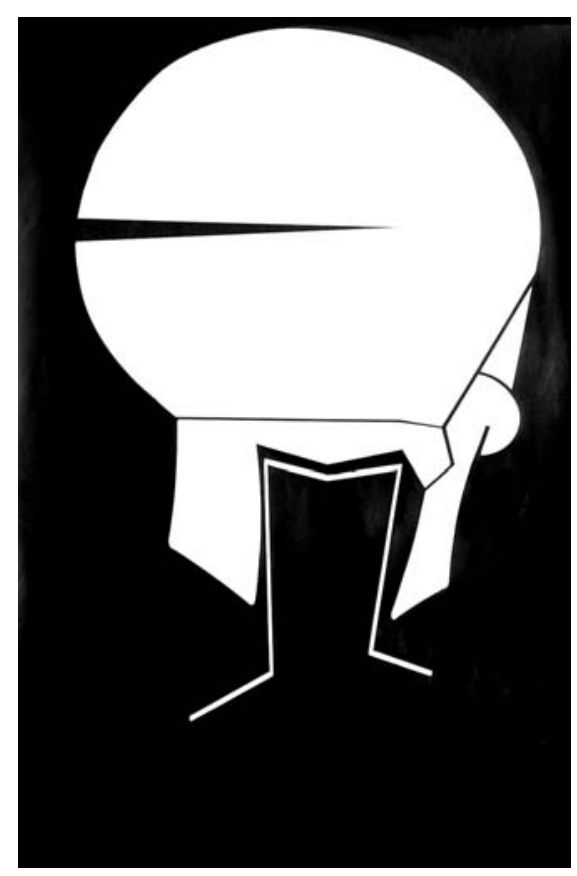

Rita Breda 

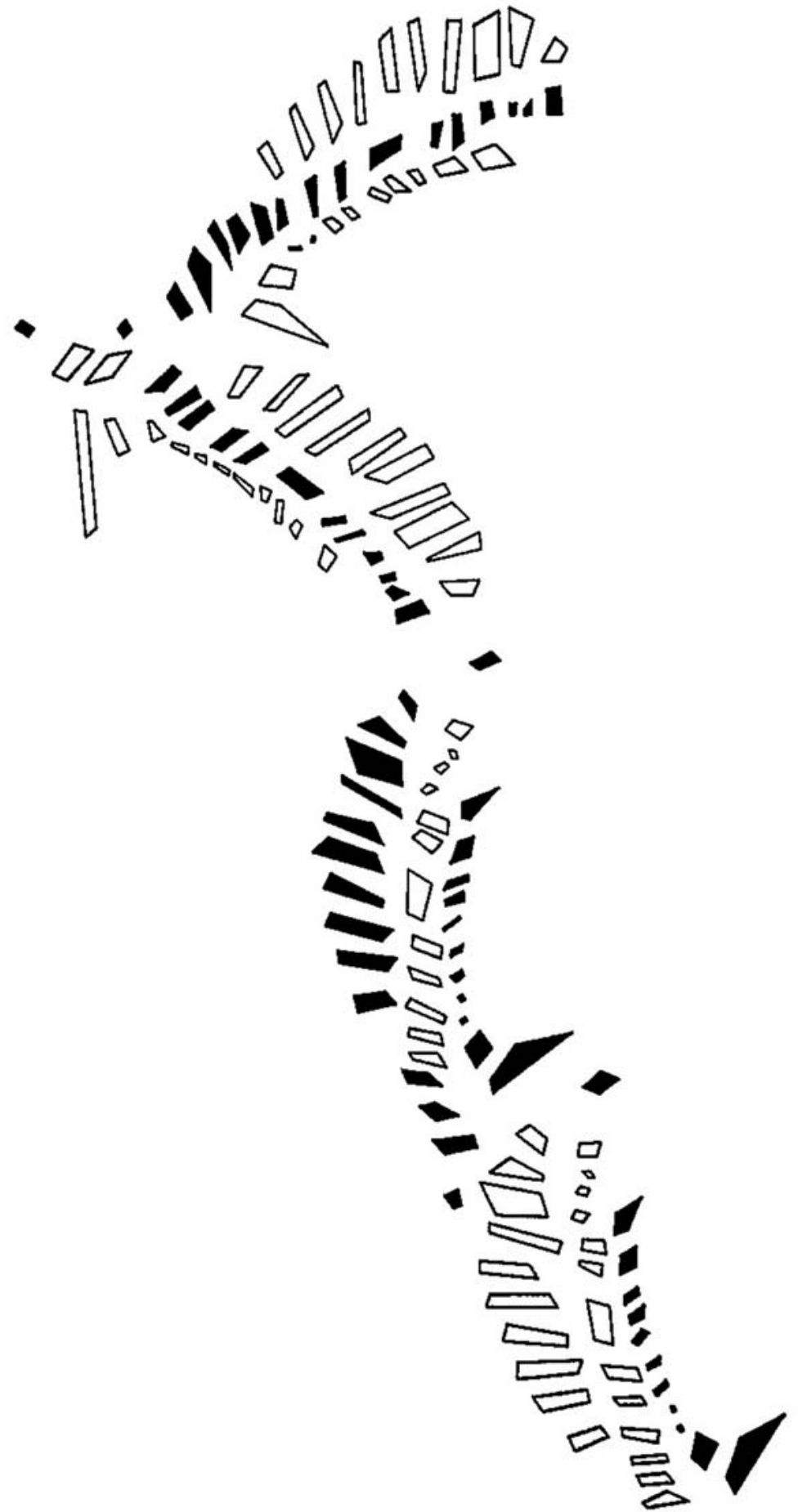


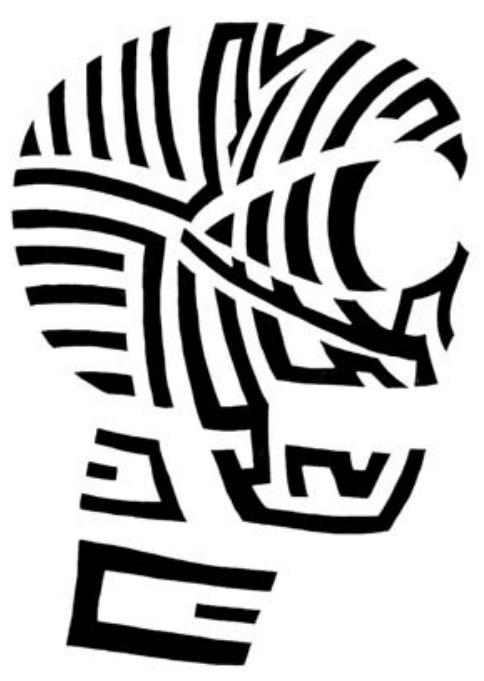

Hugo Serrano

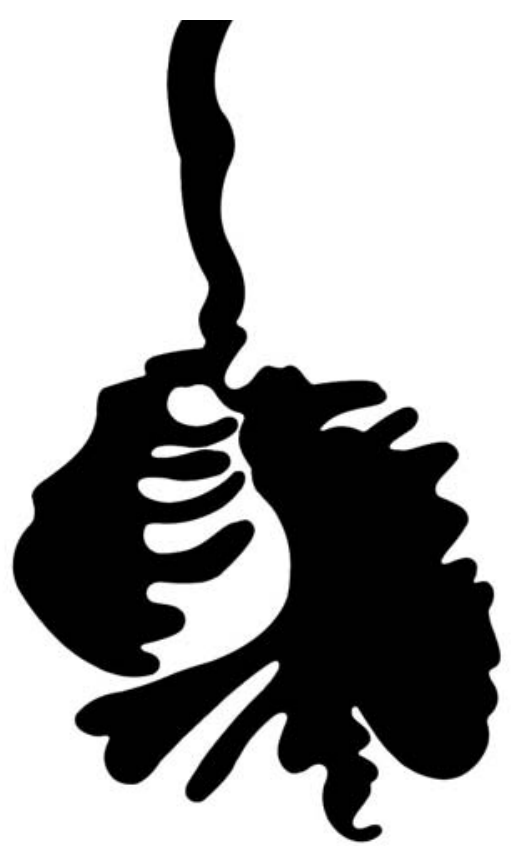

Andreia Mealha

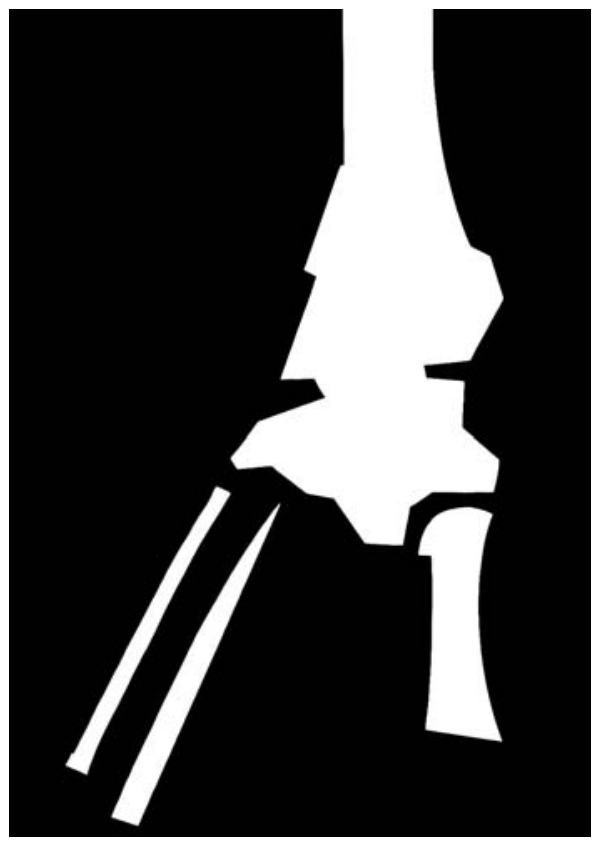

131
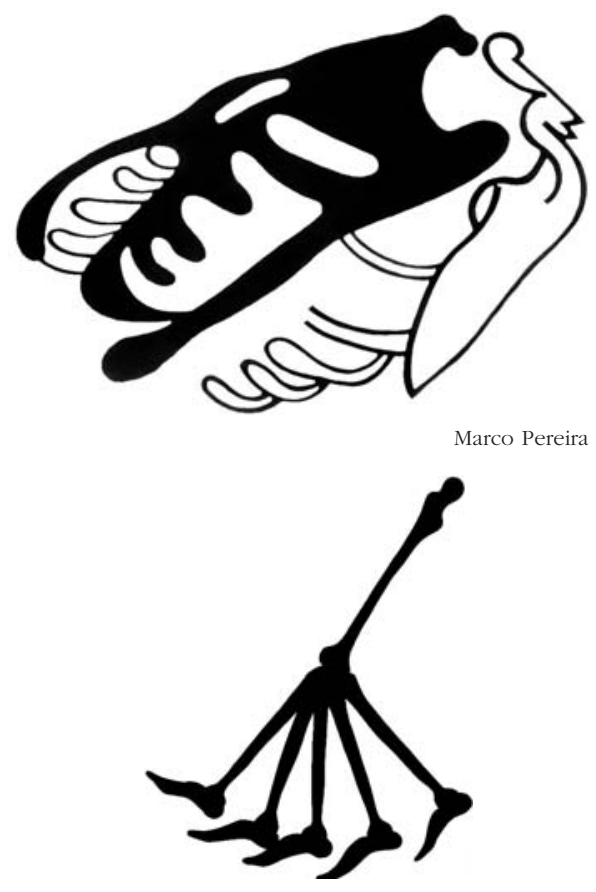
132

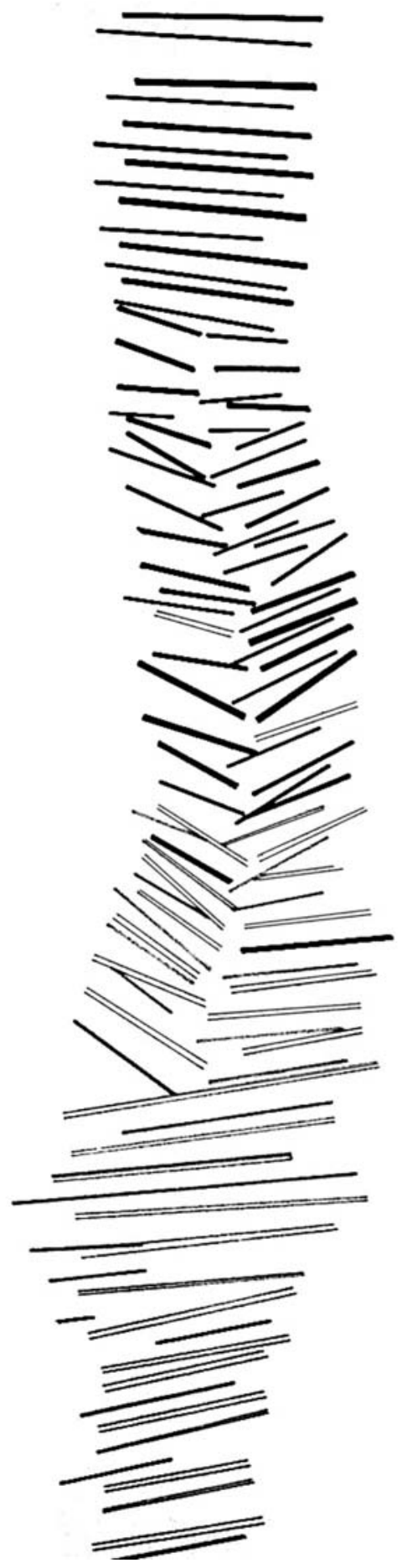

Ana Cerqueira 

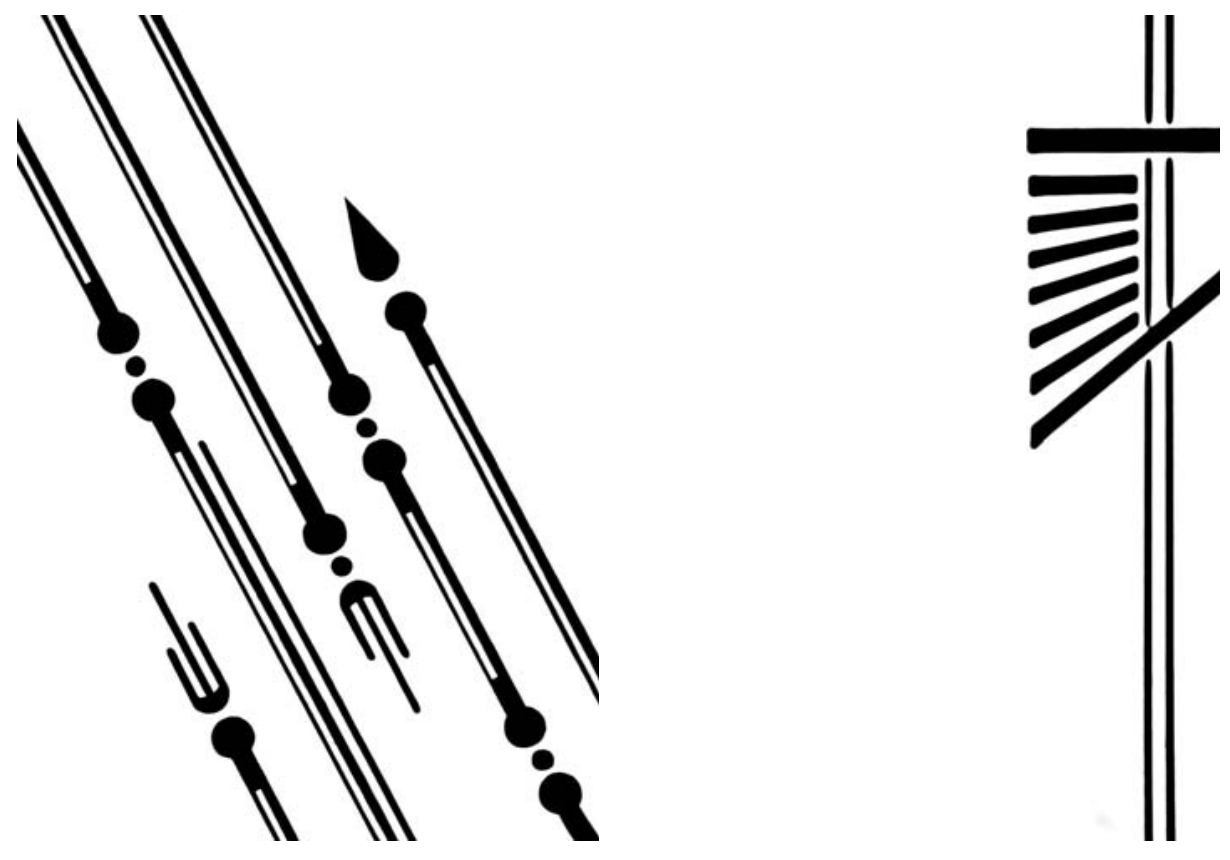

133

Ana Pratas
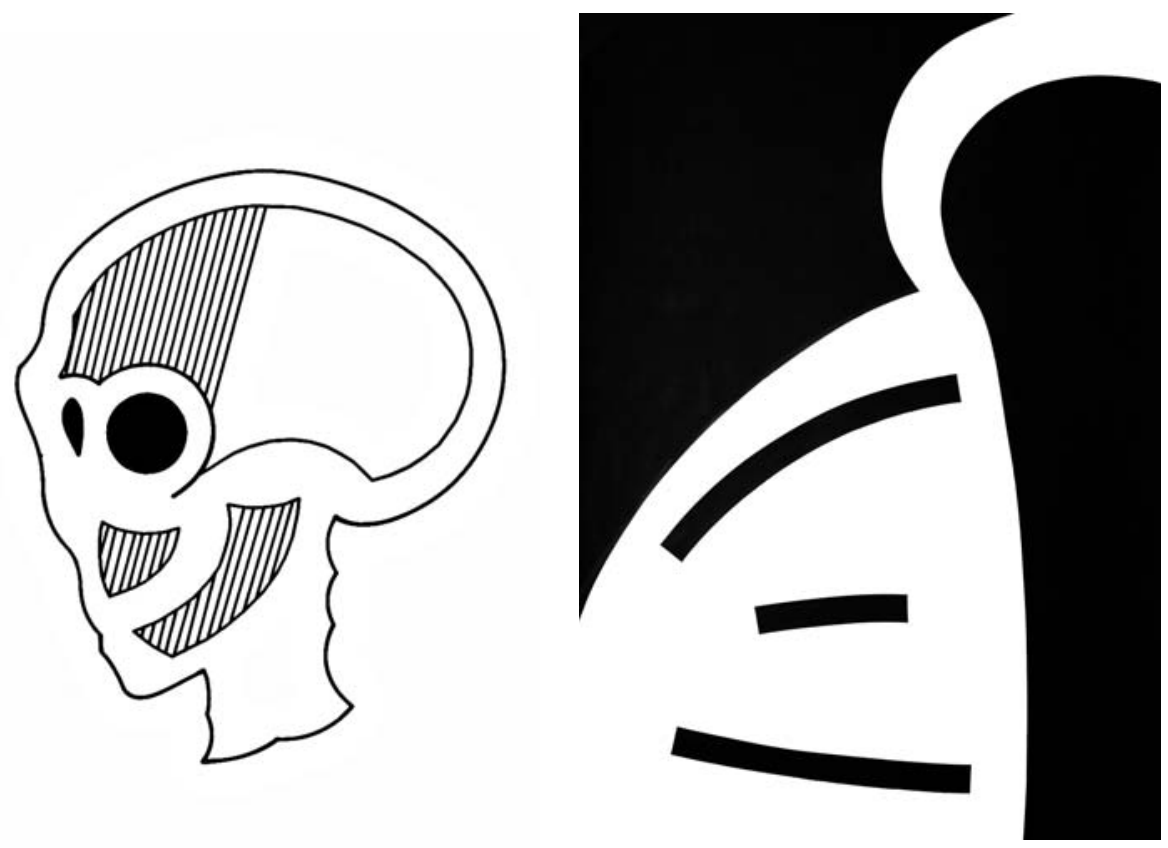

Hipólito Alfino

Joana Pocinho 
134

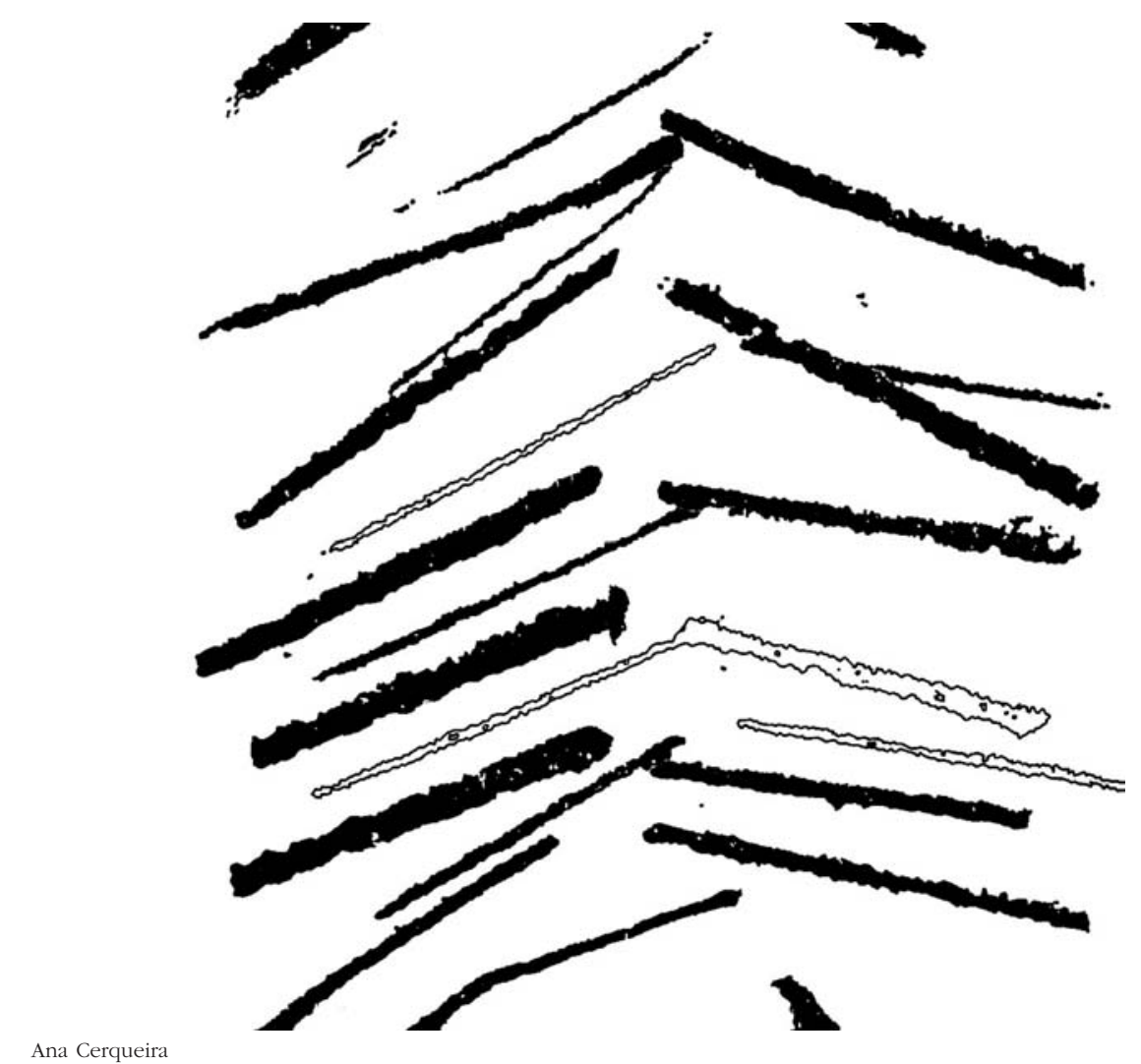

Ana Cerqueira
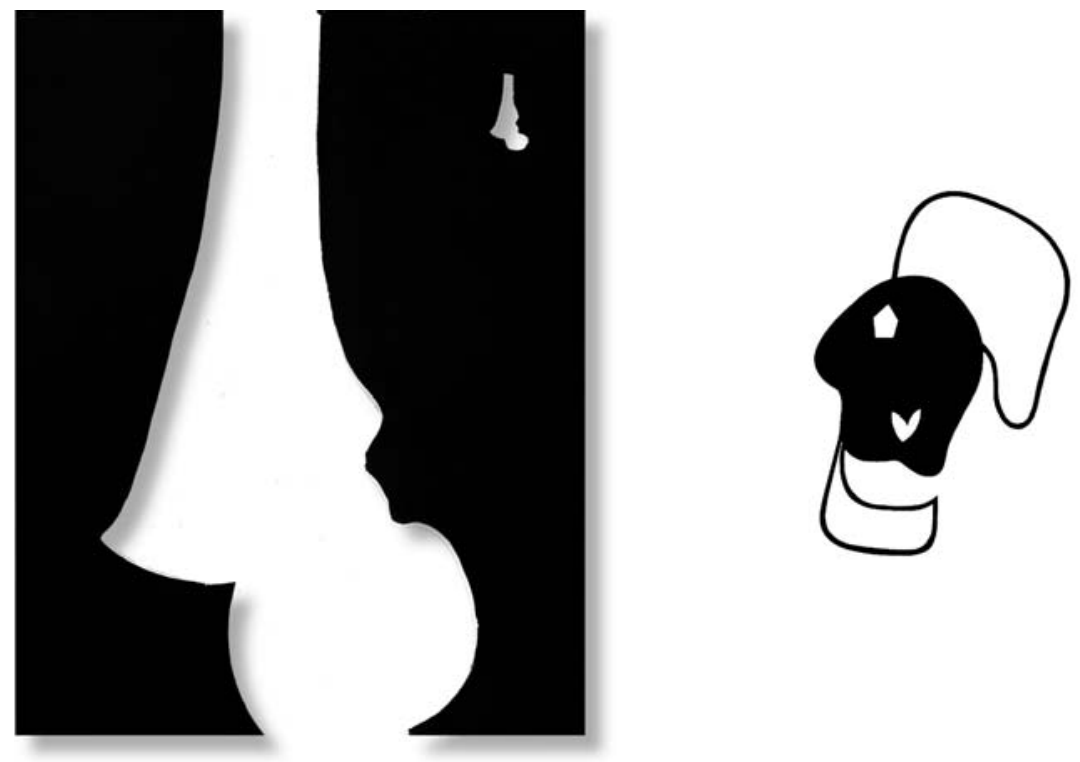

Marco Pereira 

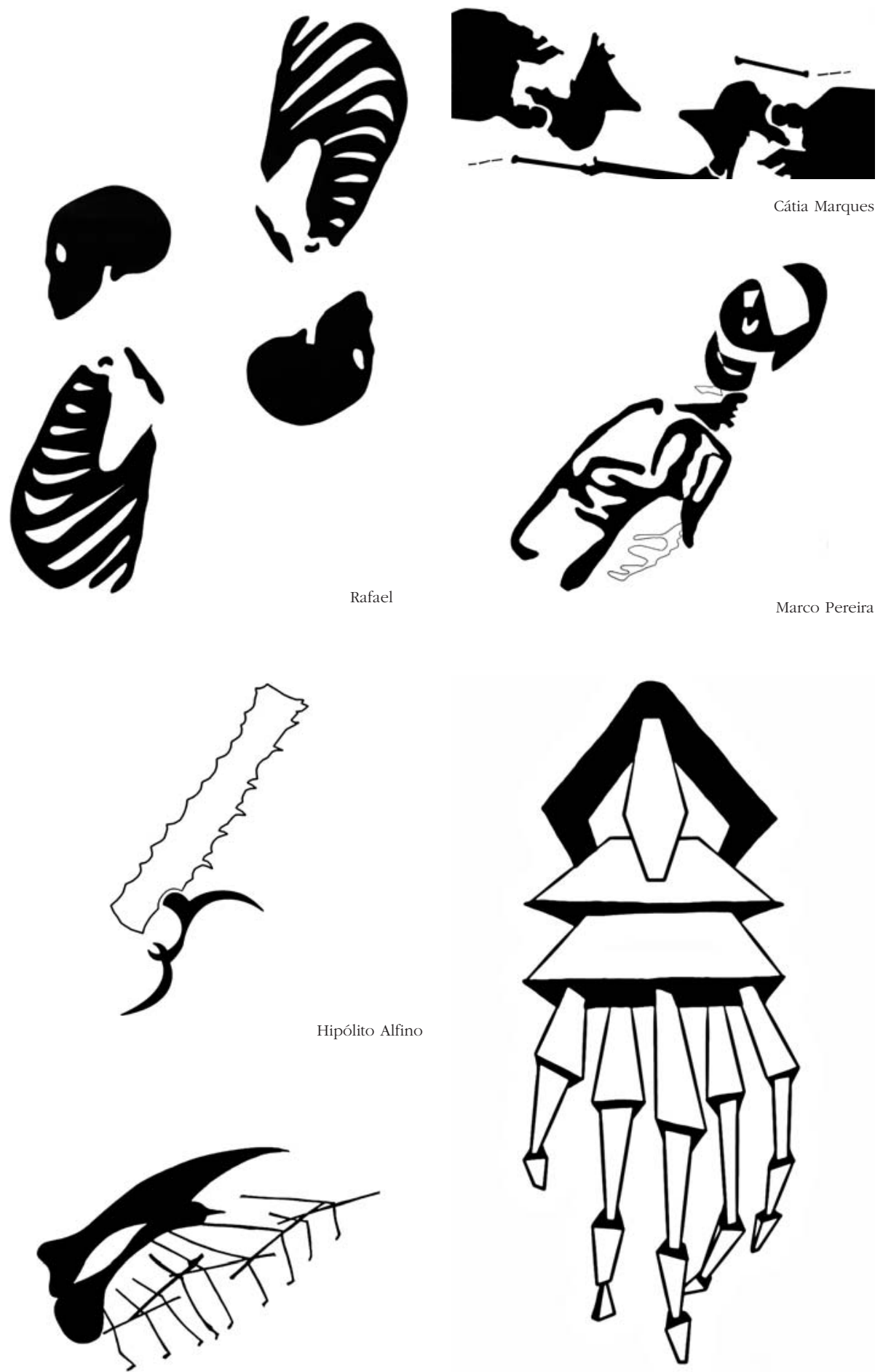

Tiago Silva 

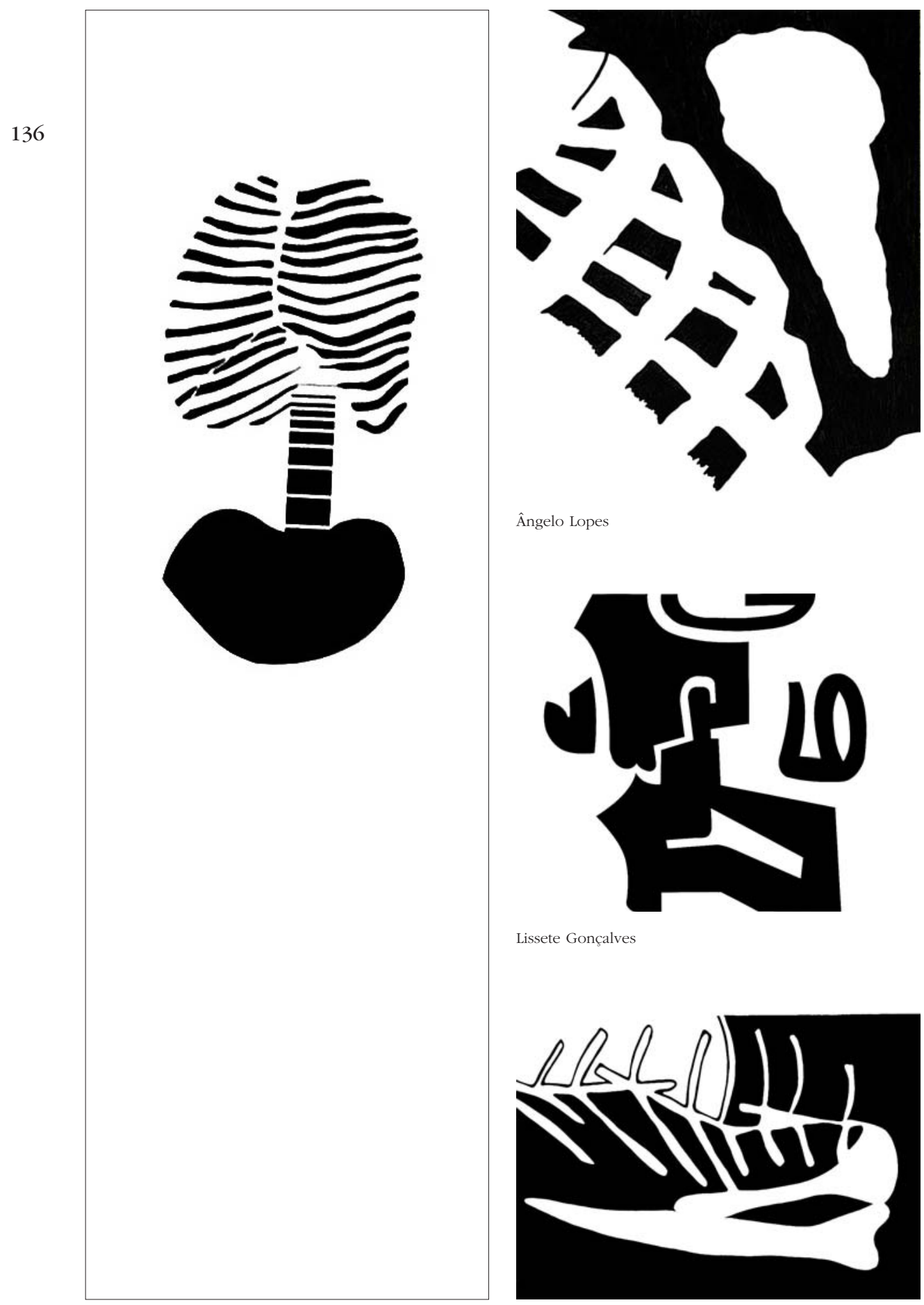

Ângelo Lopes

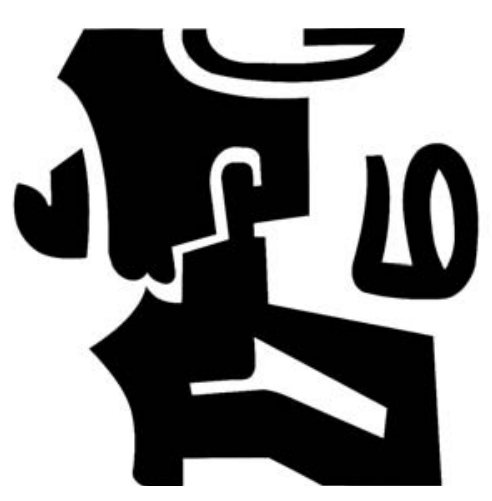

Lissete Gonçalves

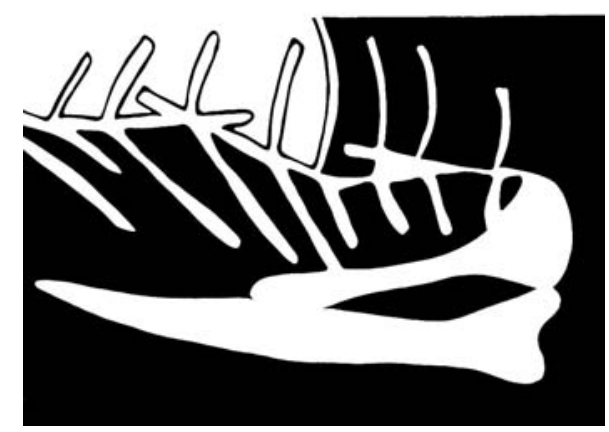

Filipe Norelho

Tiago Silva 

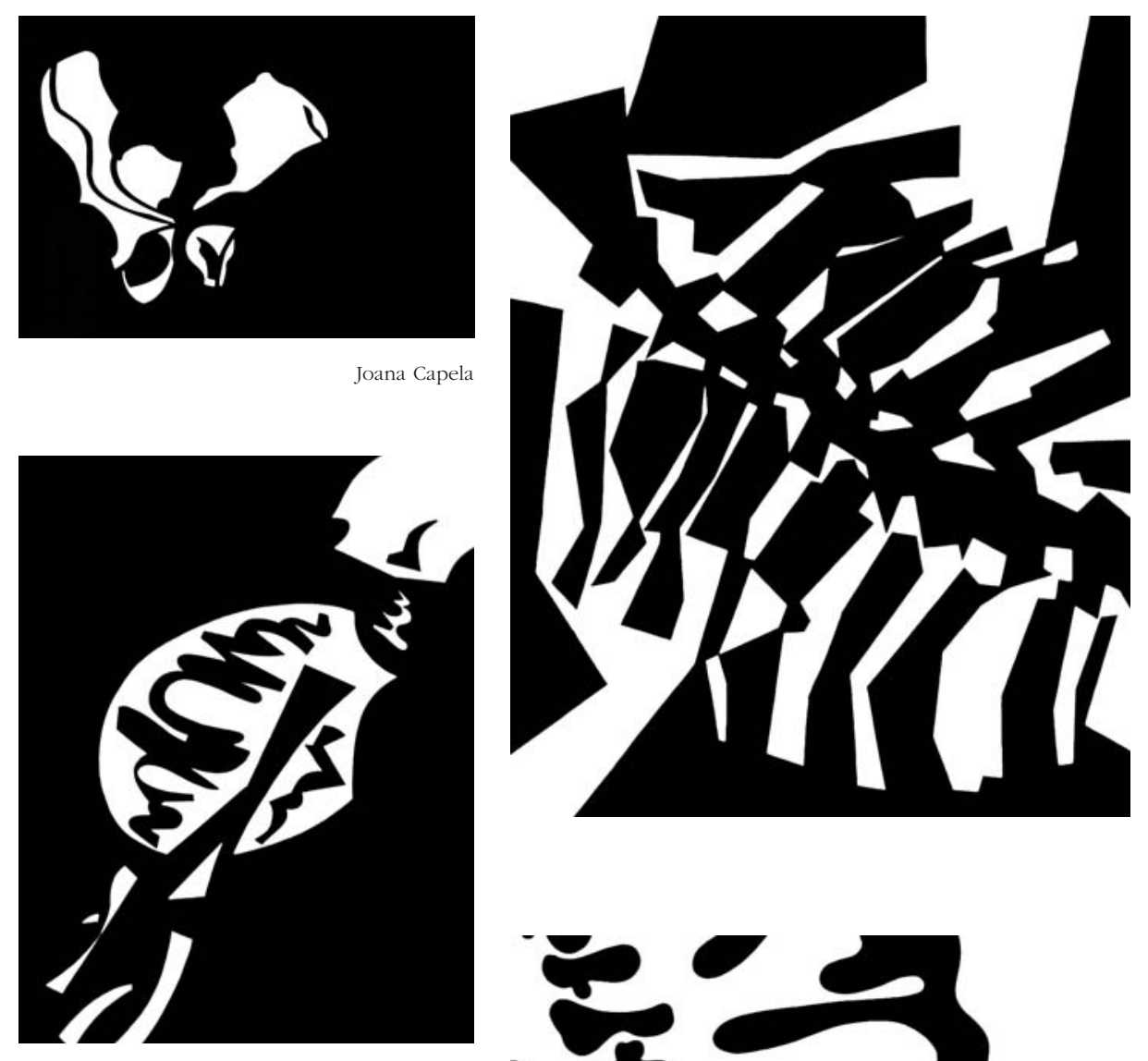

Joana Capela

João Albuquerque
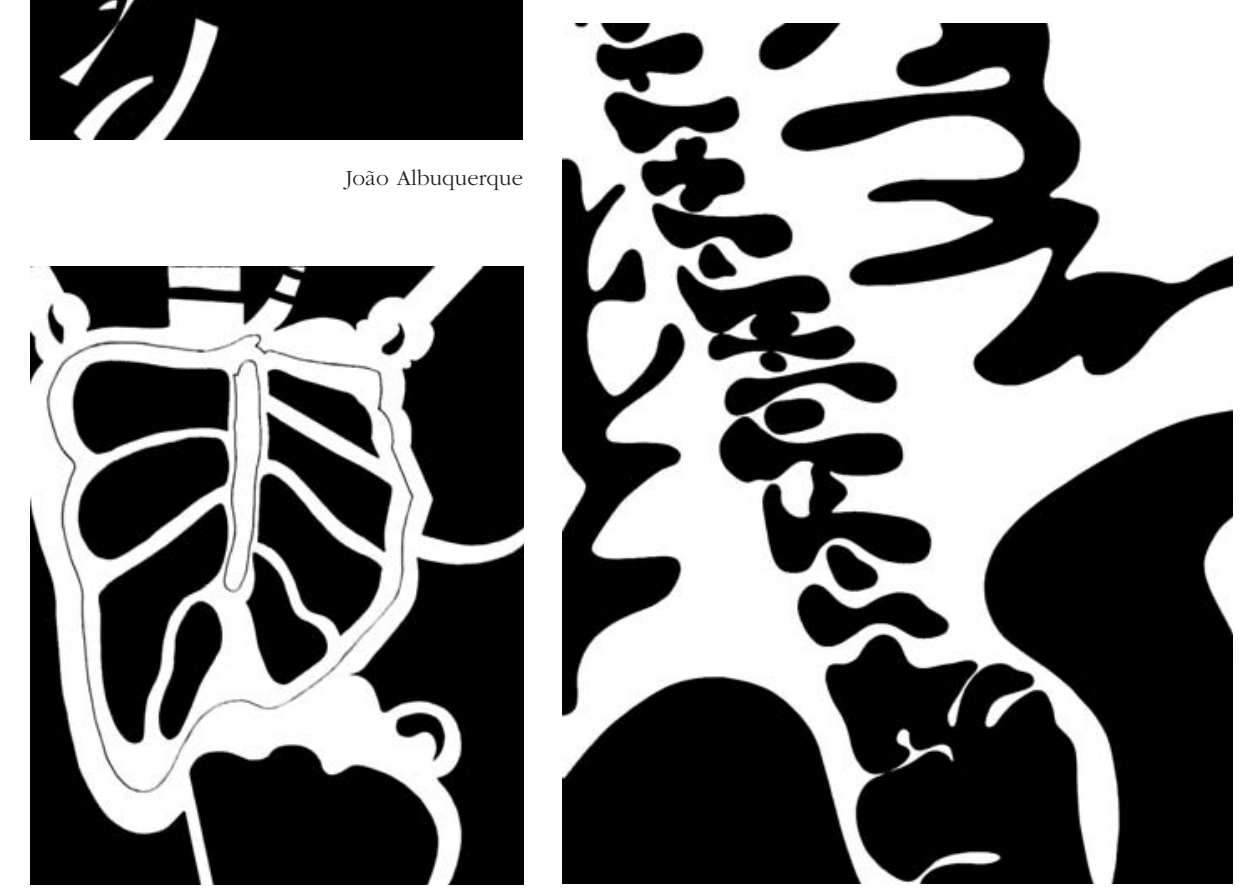

Duarte Cerqueira

João Albuquerque 


\section{8}
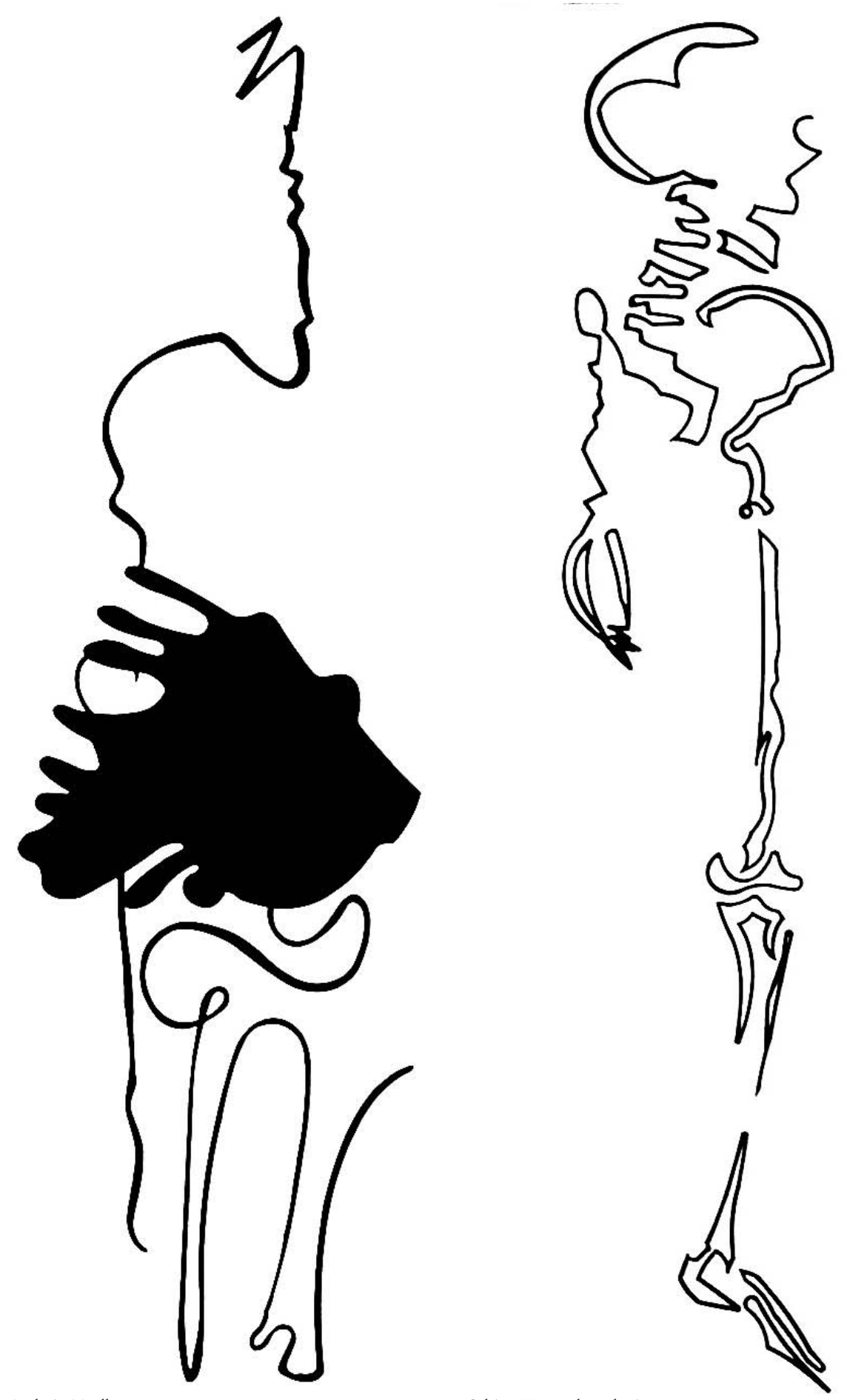

Sabina Karamehmedovic 

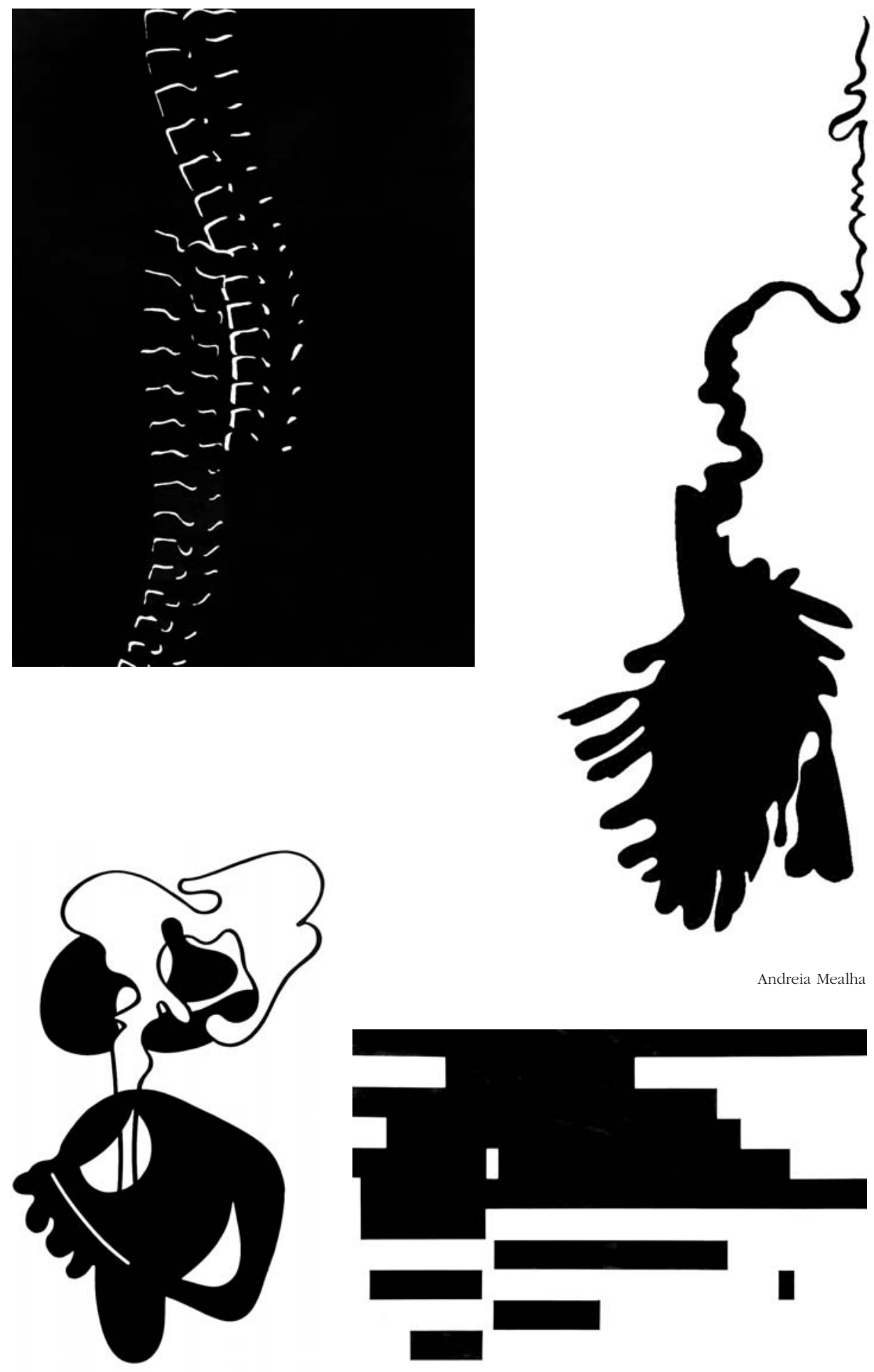
140

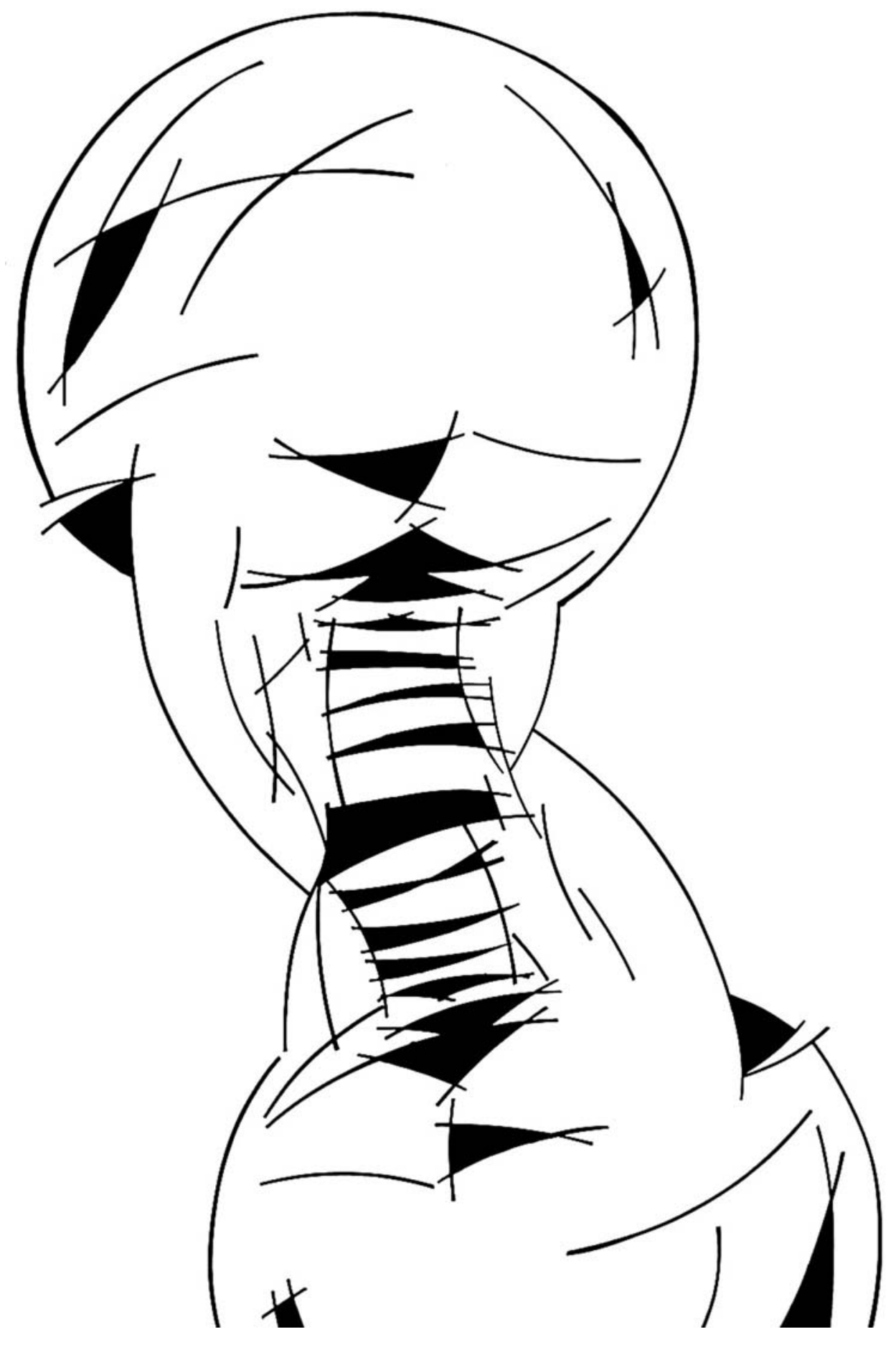




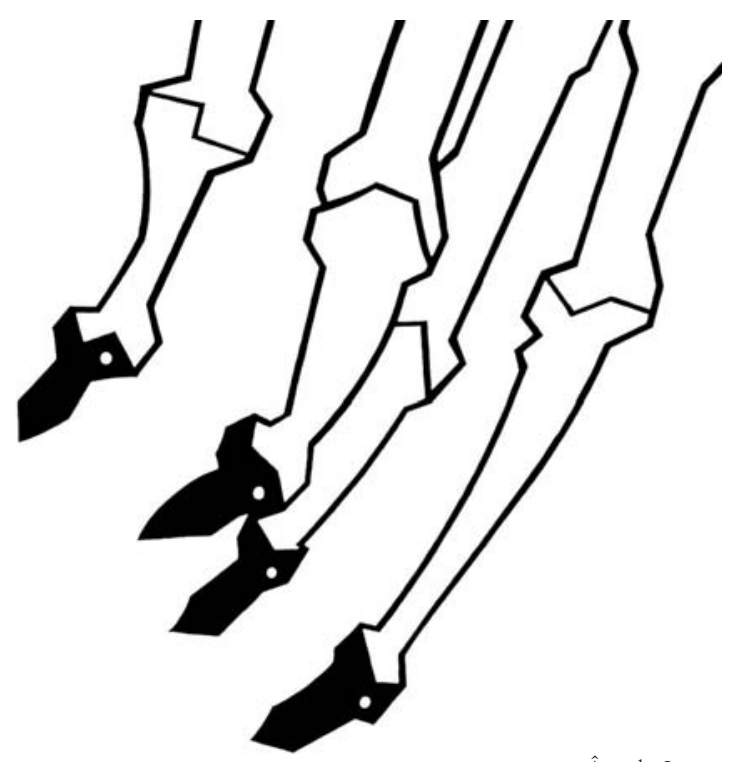

141

Ângelo Lopes

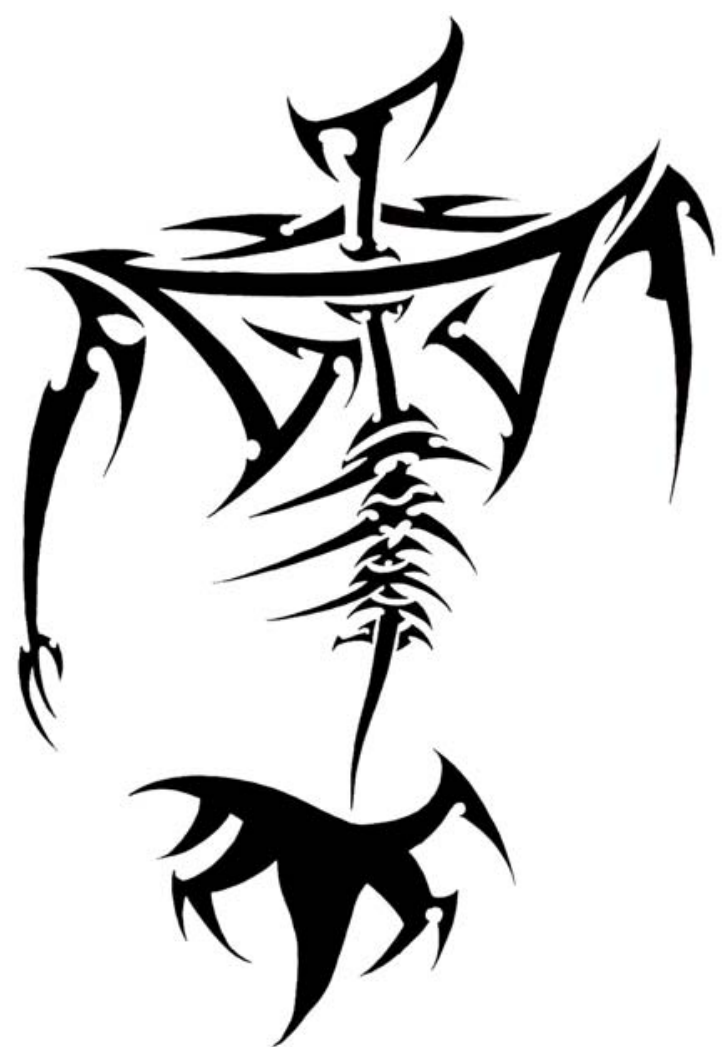

Hugo Serrano 
142
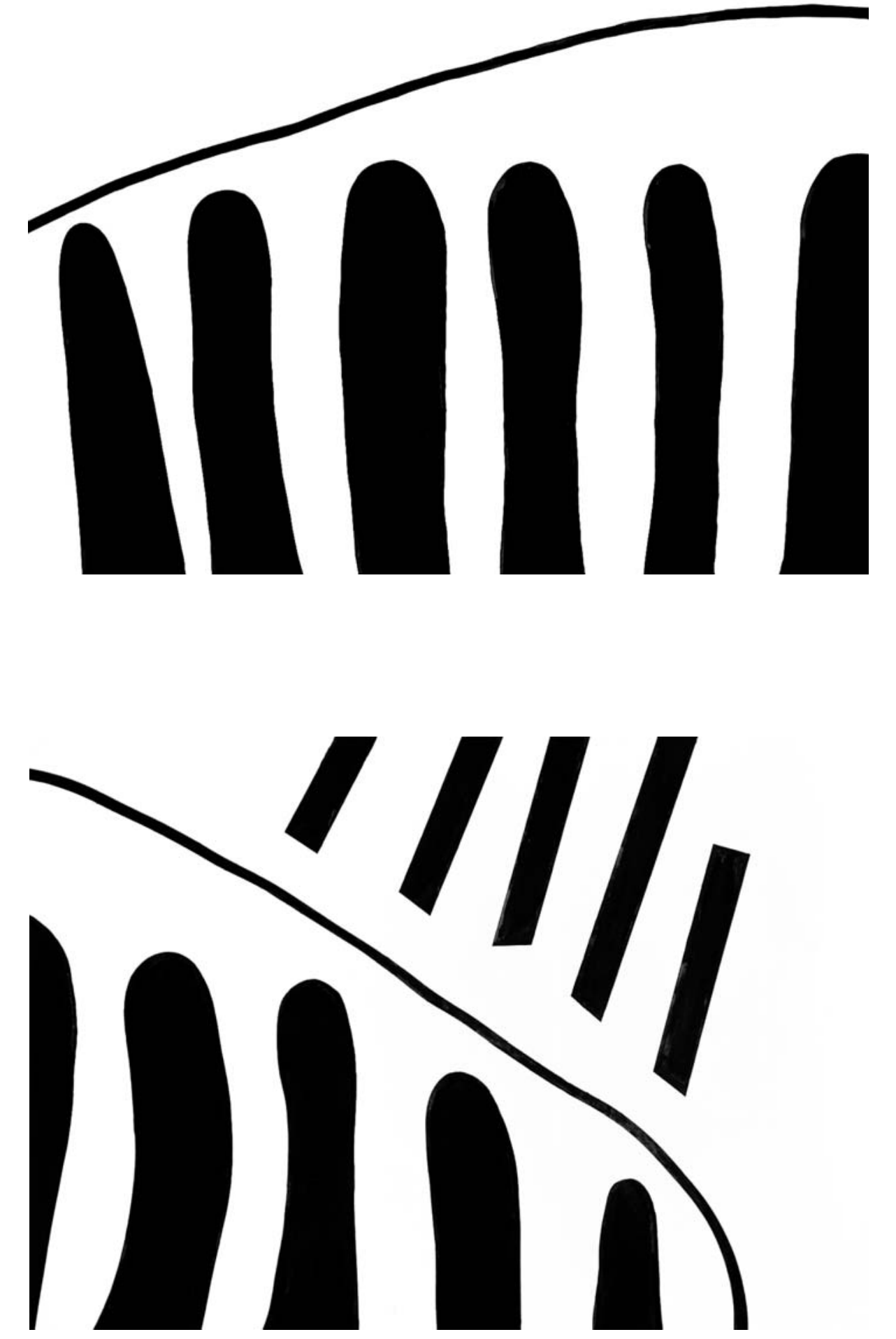


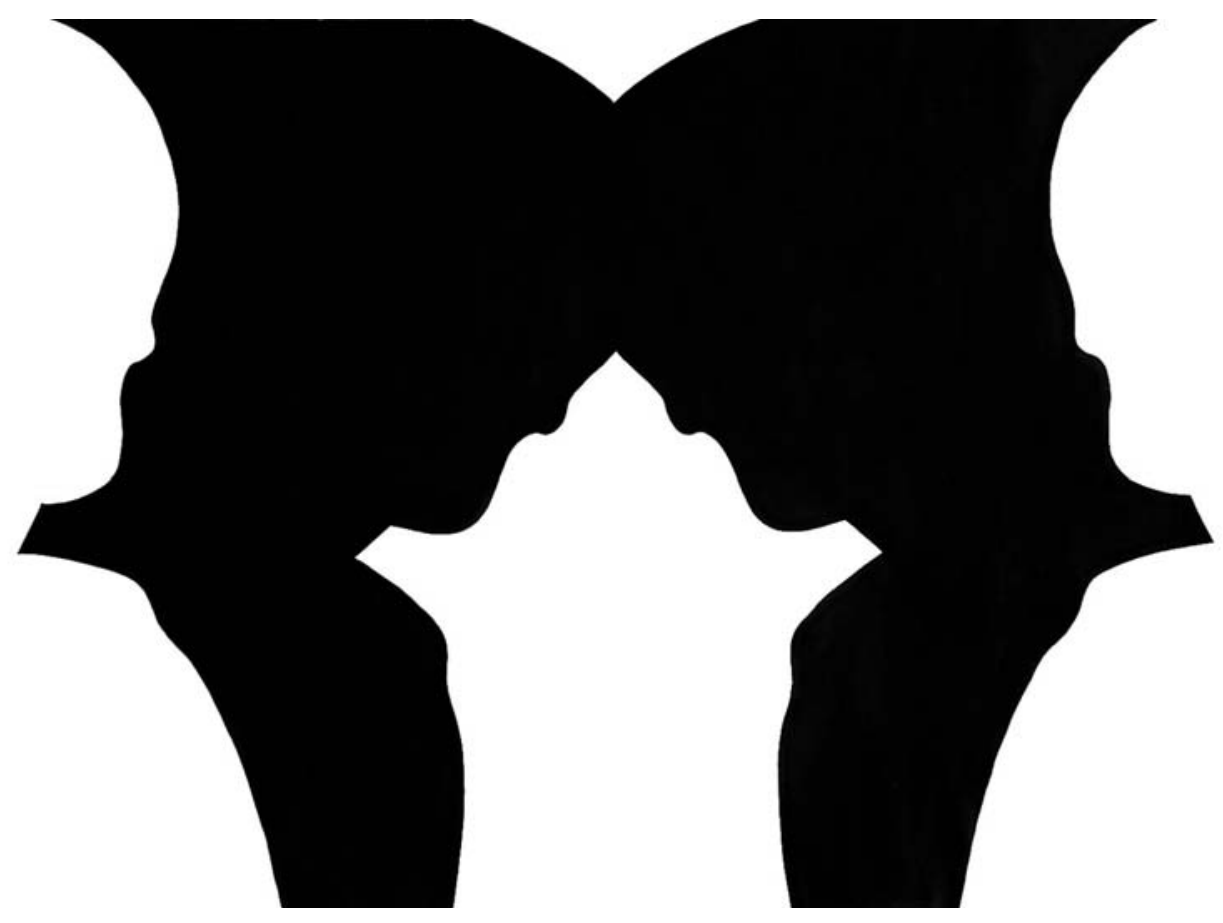

Patrícia Reis

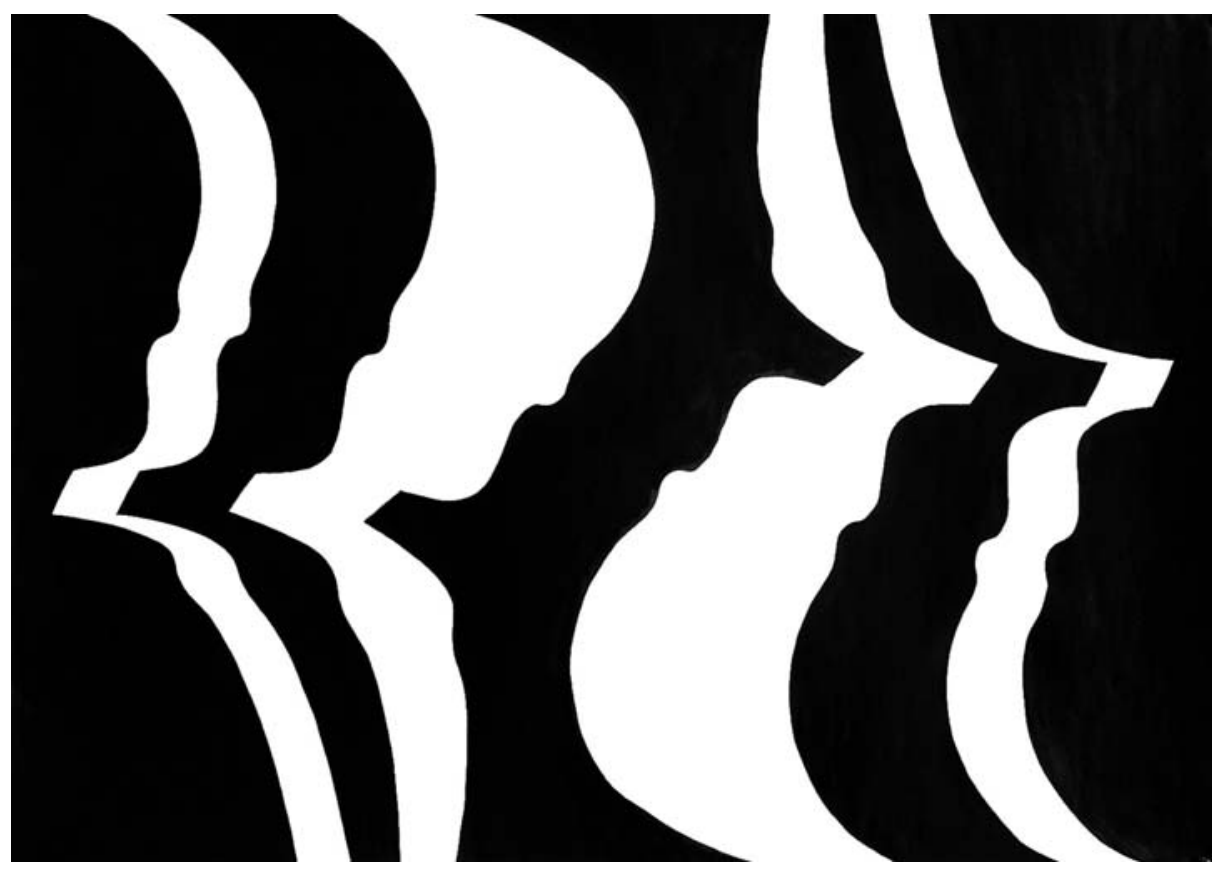

Patrícia Reis 


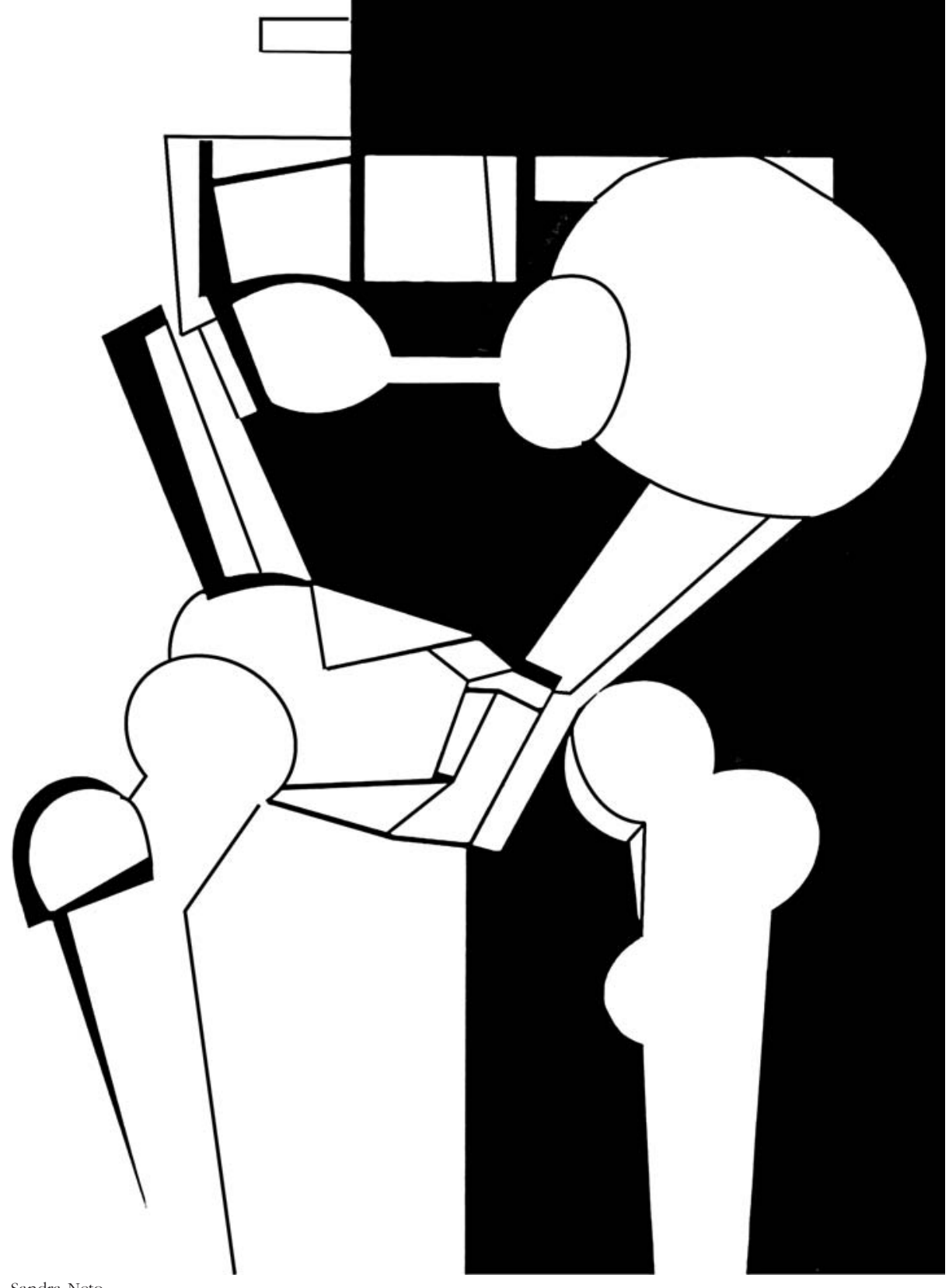



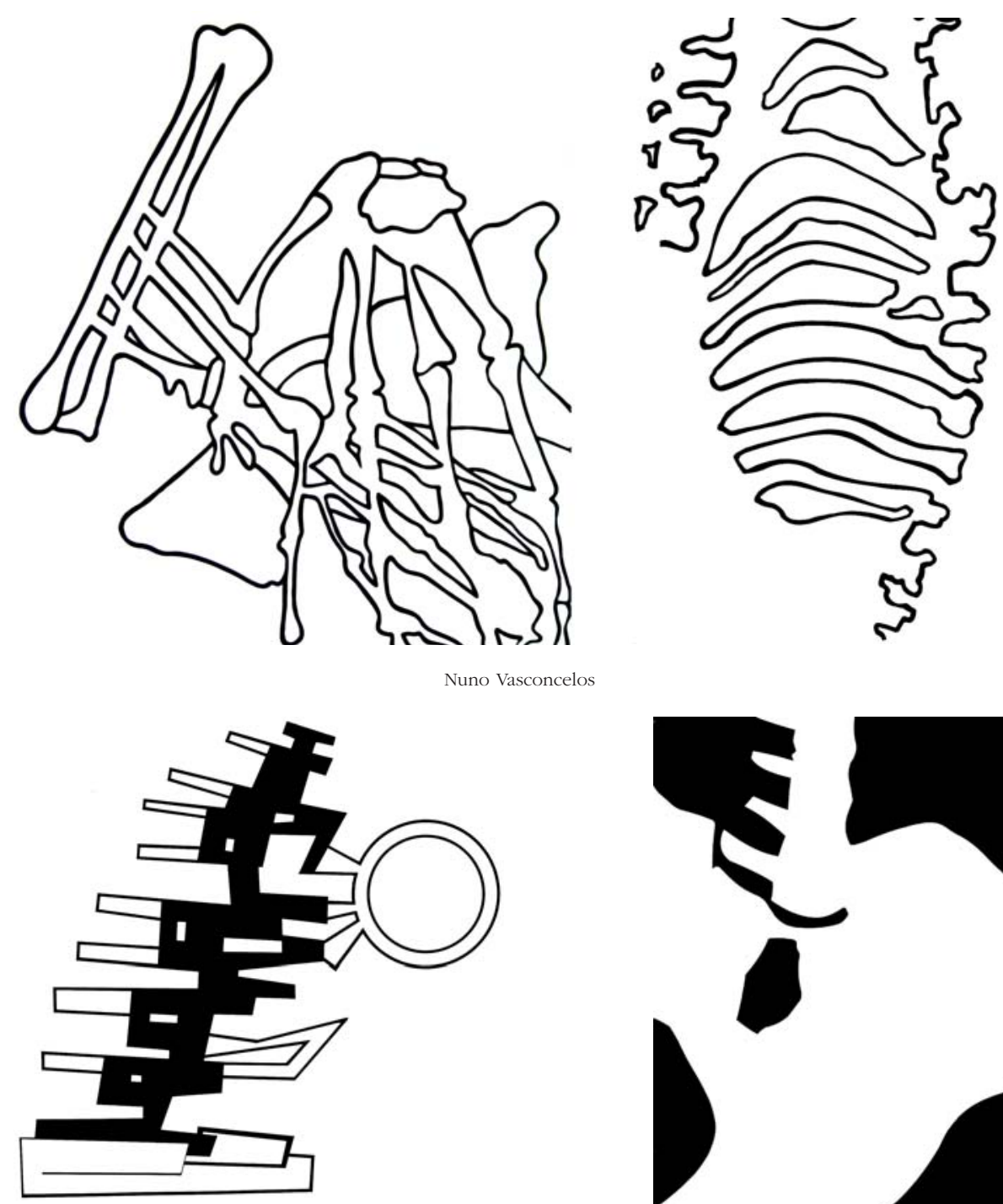

Agostinho Martins
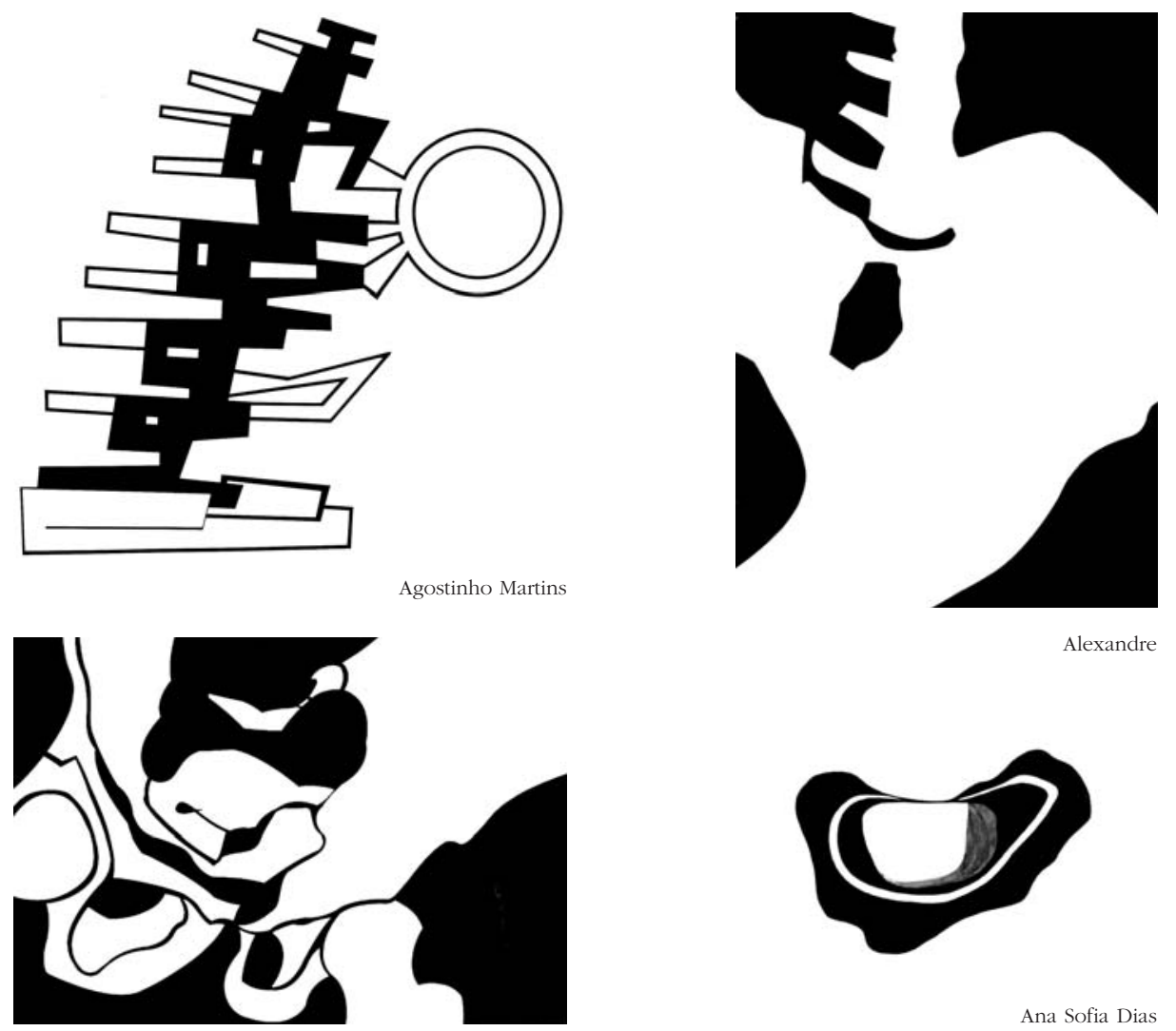

Ana Sofia Dias 
146

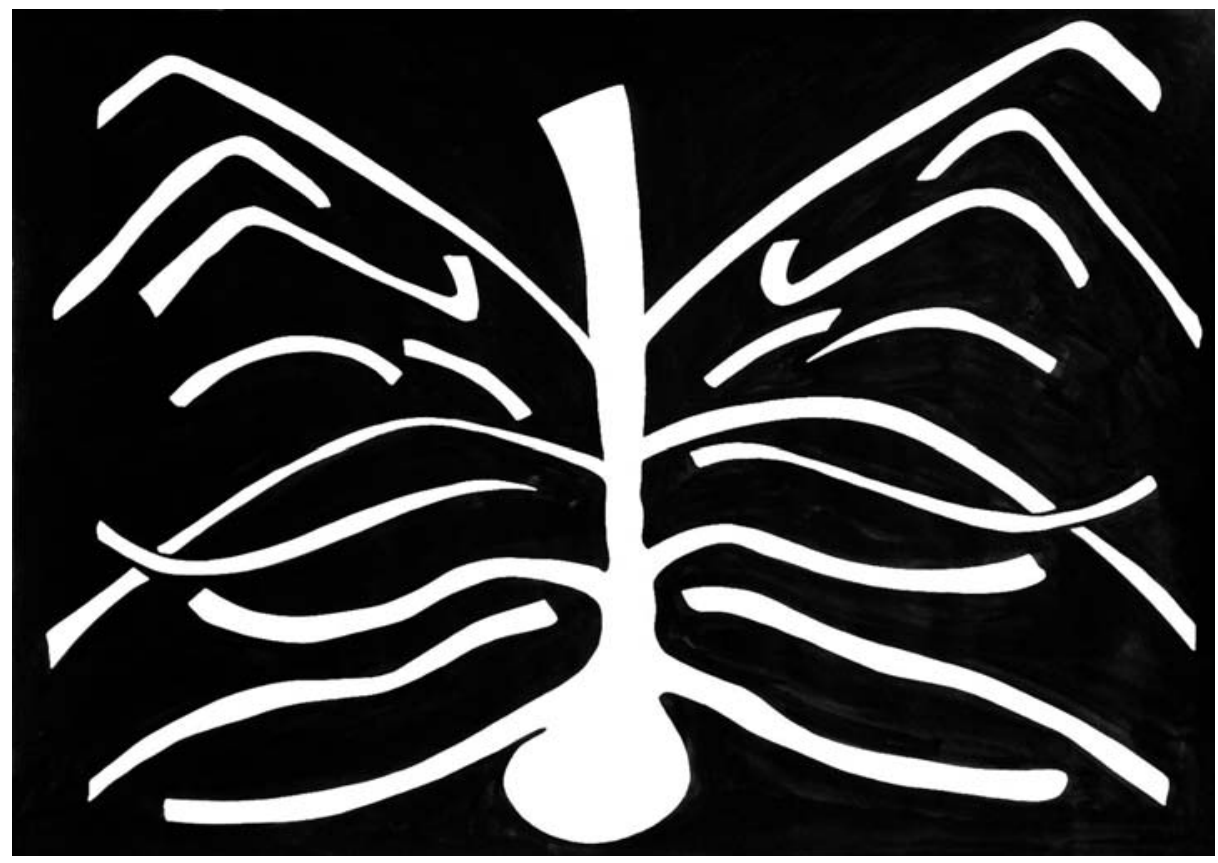

Tiago Silva
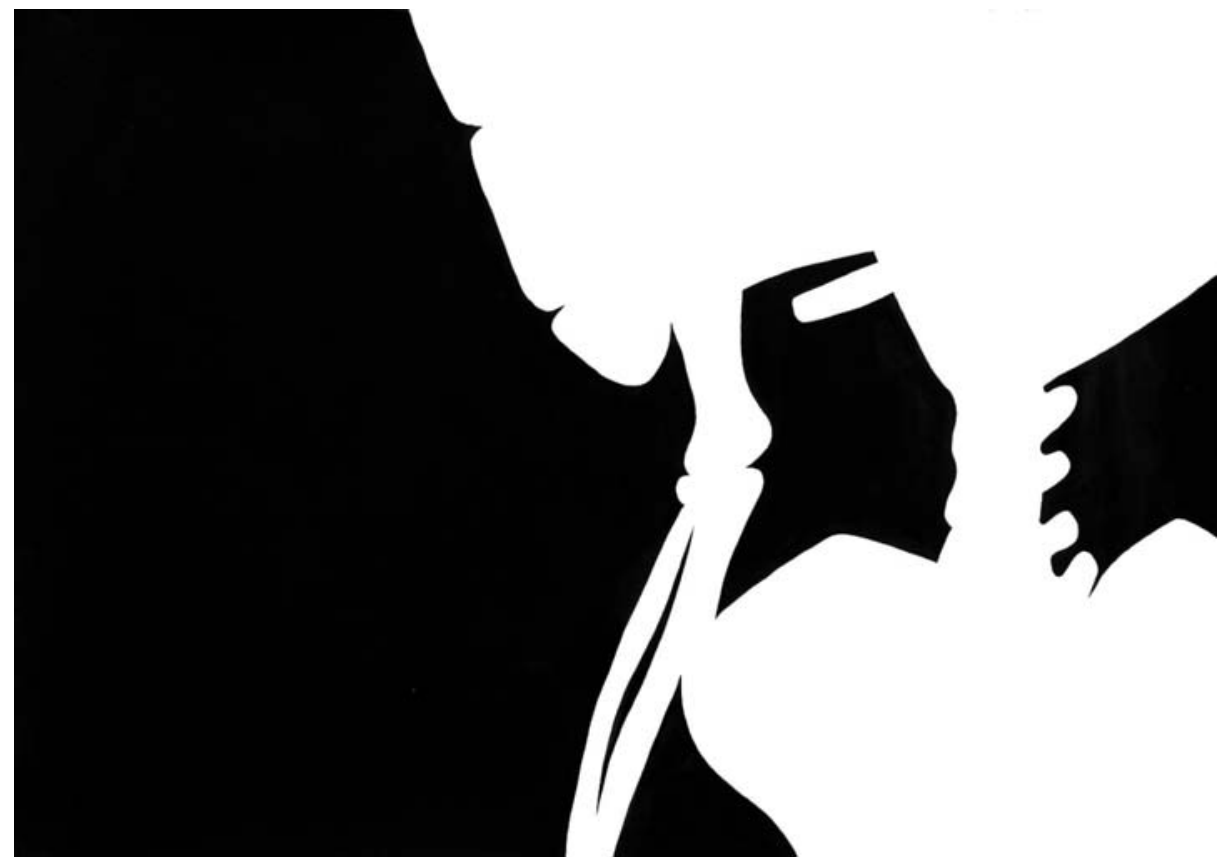

Patrícia Reis 


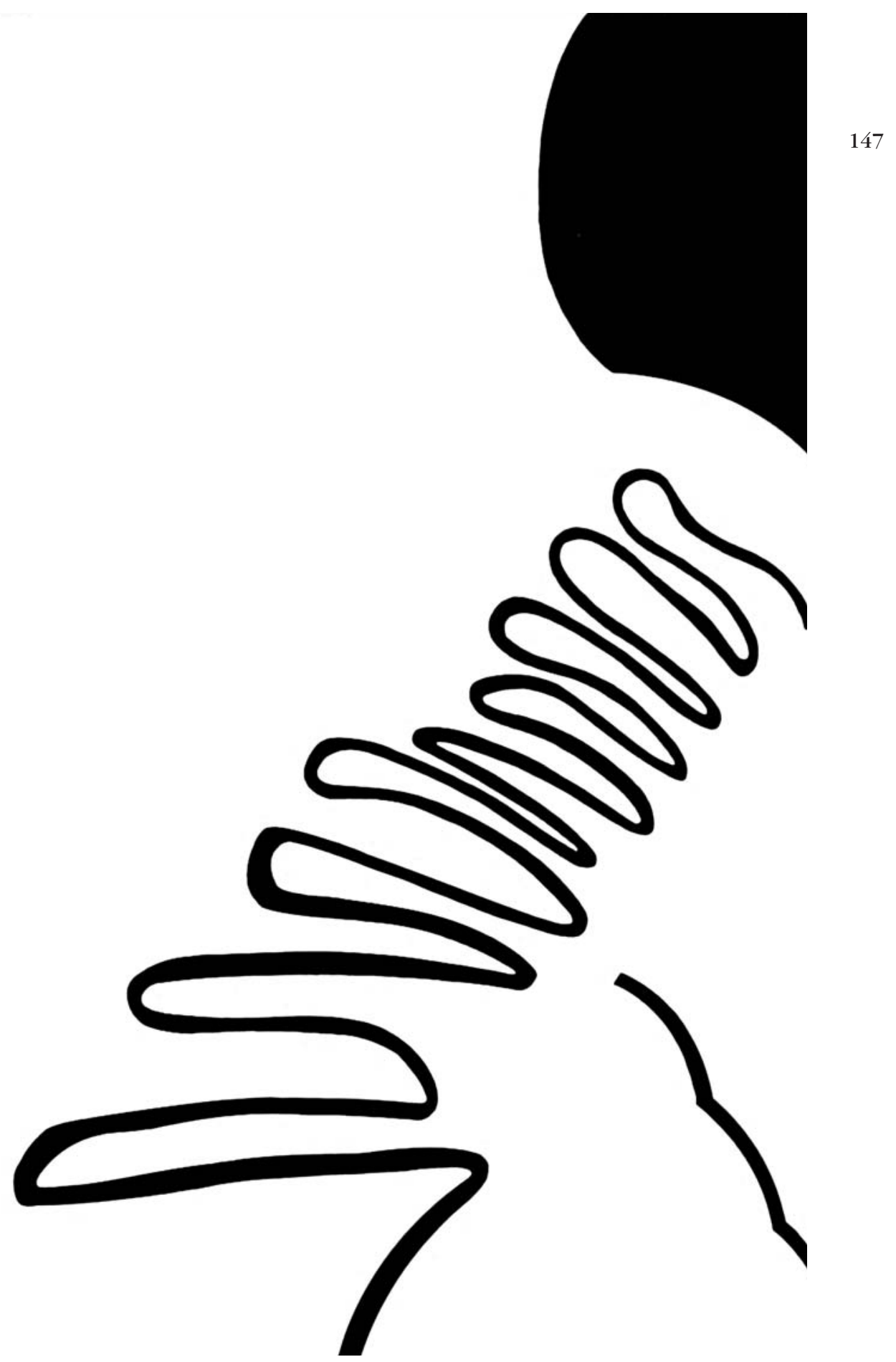

Joana Pocinho 
(Página deixada propositadamente em branco) 
EXPLORAÇÃO FORMAL E POÉTICA DA AMBIGUIDADE ENTRE A BIDIMENSIONALIDADE E A SUGESTÃO ESPACIAL 
(Página deixada propositadamente em branco) 
Utilizando a elementaridade gráfica do contraste preto/ branco, os alunos desenvolveram uma série de composições onde indícios de uma representação espacial se cruzam com a afirmação compositiva da bidimensionalidade do suporte.

Os resultados surgem assim, numa espécie de vertigem que dissolve coordenadas, na construção destes espaços imaginários.

$\mathrm{Na}$ dissolução entre as duas e as três dimensões situamo-nos na abstracção do jogo das essencialidades formais 
152

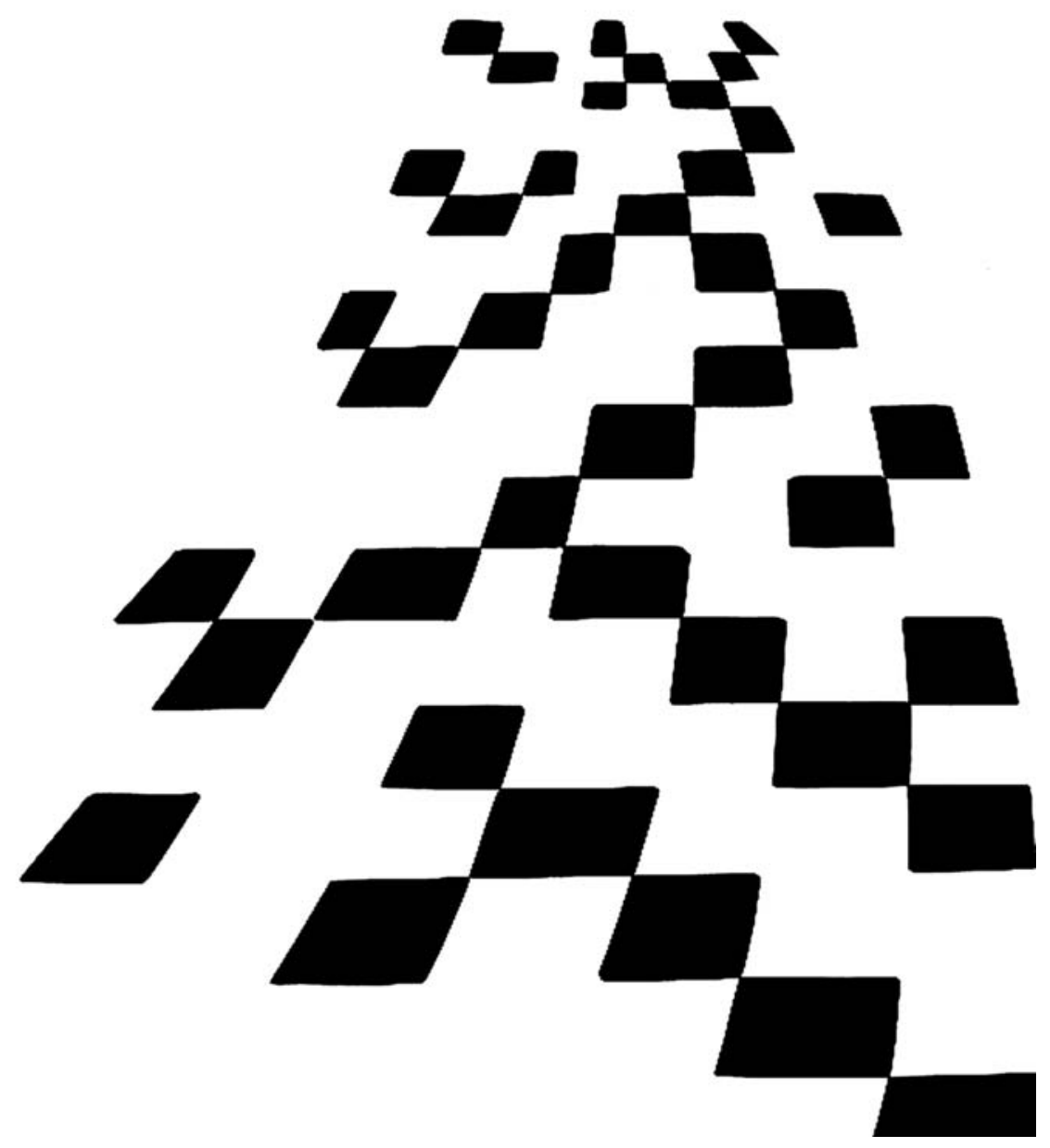




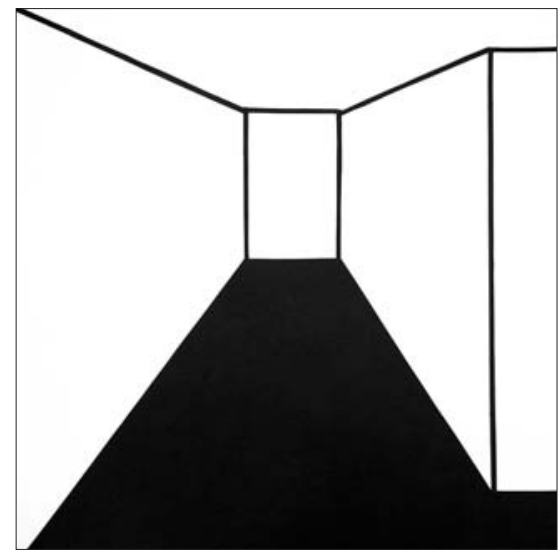

André Oliveira

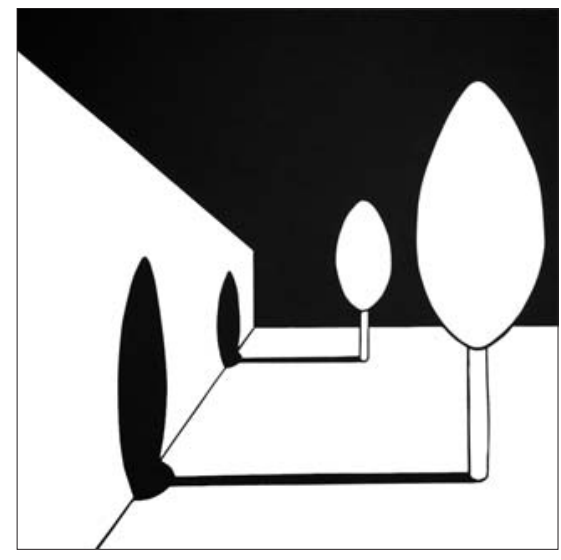

Cristiano Pepi

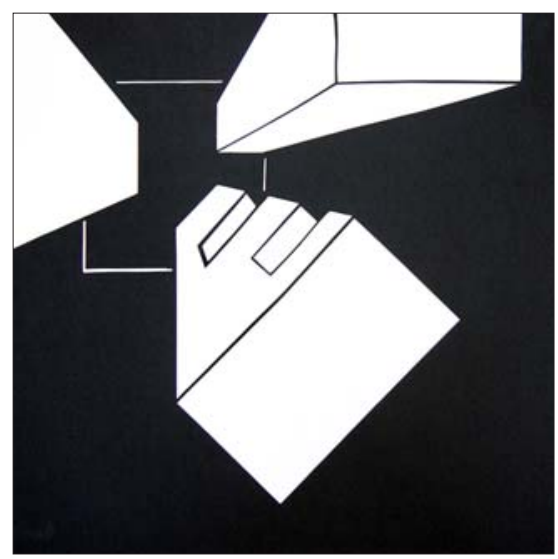

Susi Silva

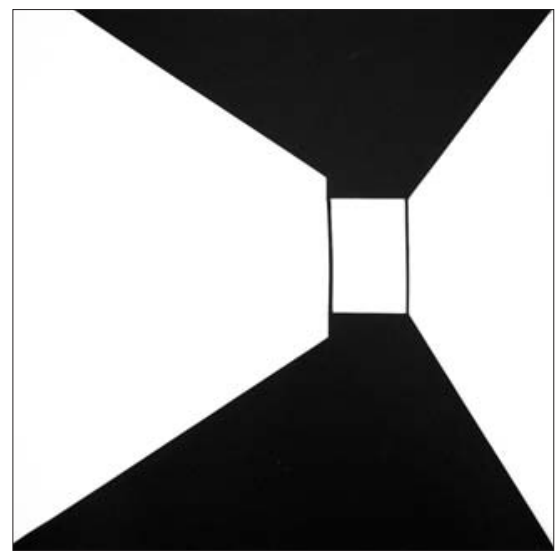

153

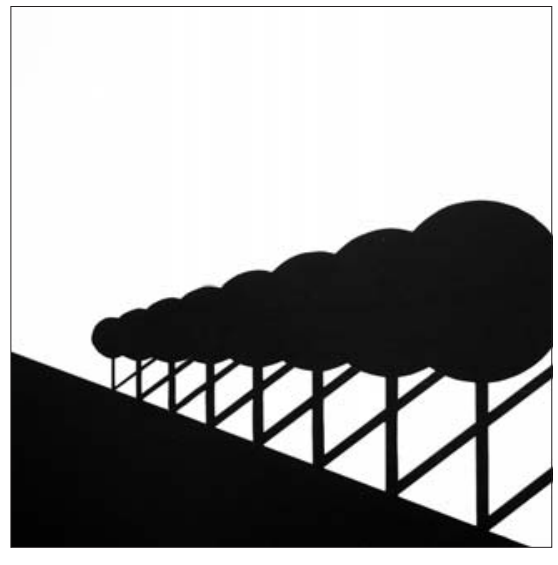

Ana Ferreira

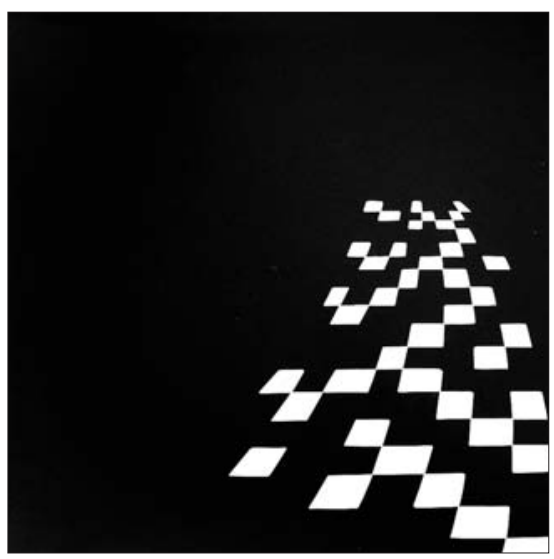

Daniela Rebelo 


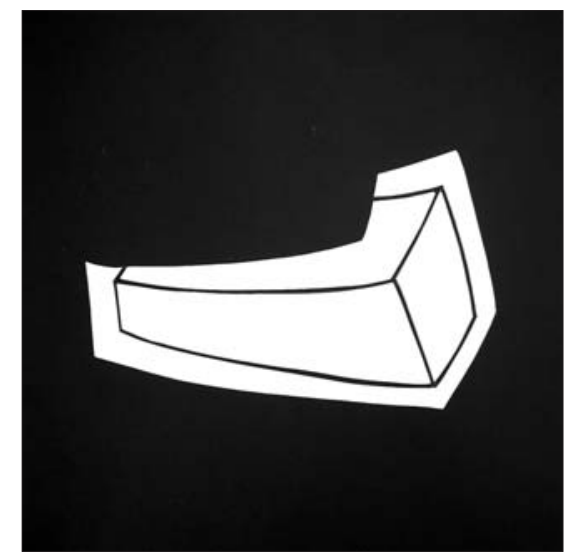

Ana Gomes

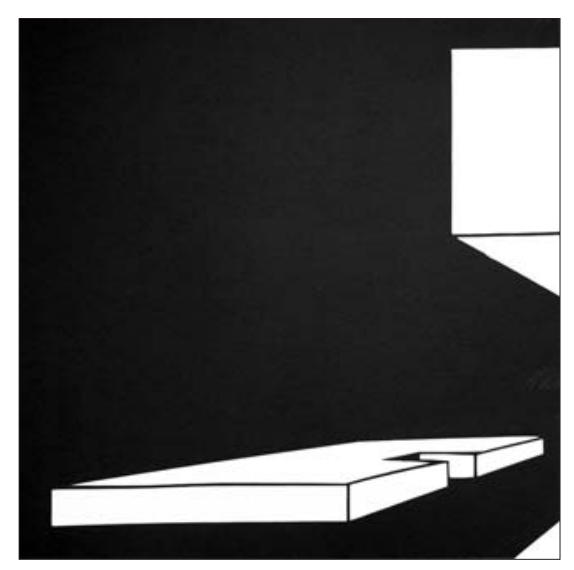

Susi Silva

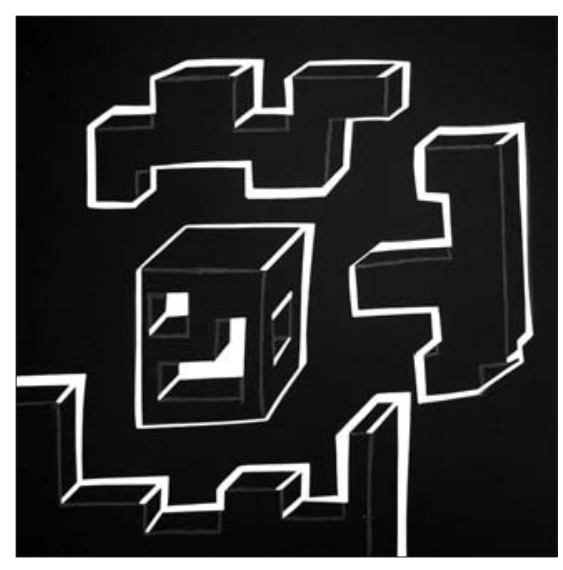

Susi Silva

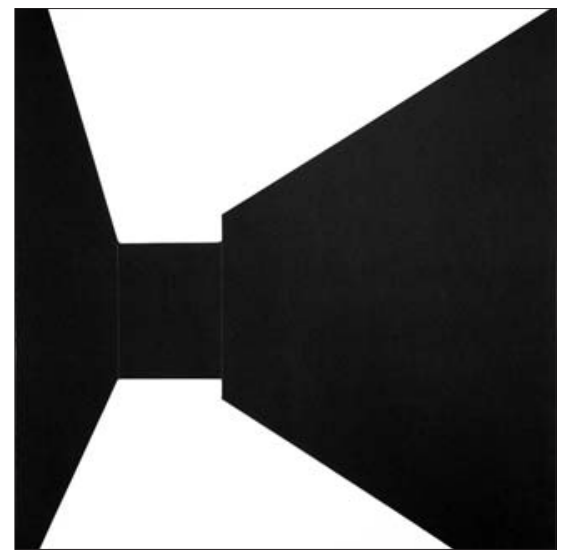

Carolina Ganhão

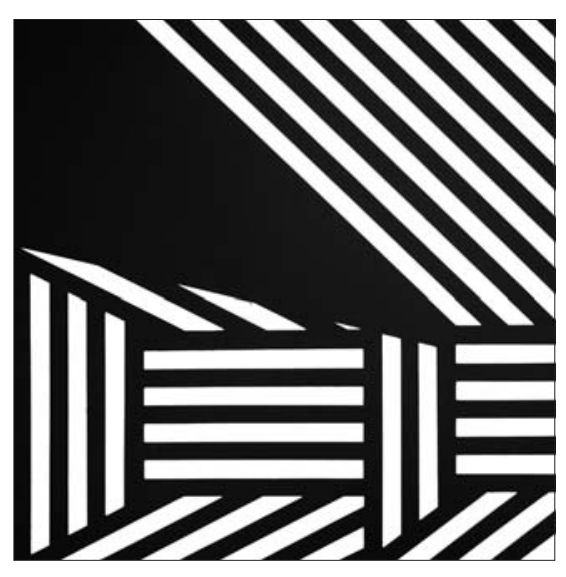

Joana Rita Ramos

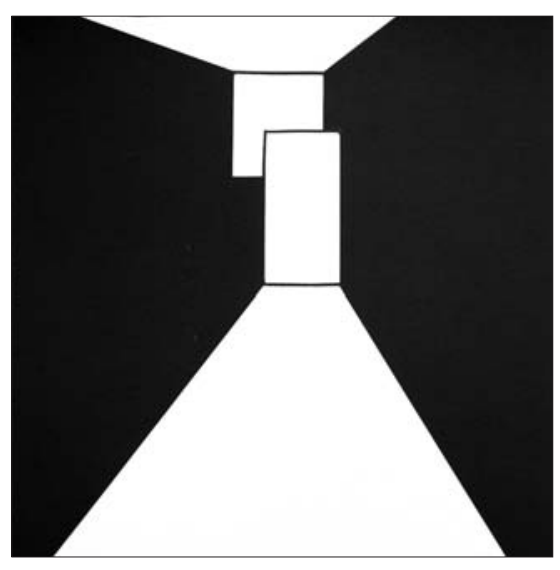

Carolina Ganhão 

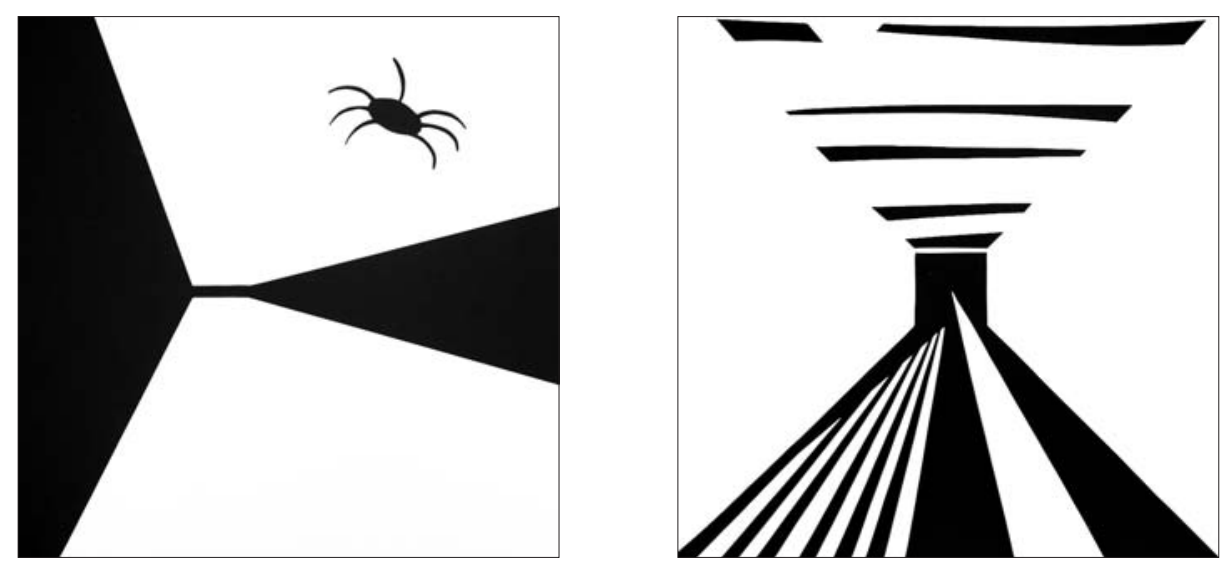

Joana Sobral
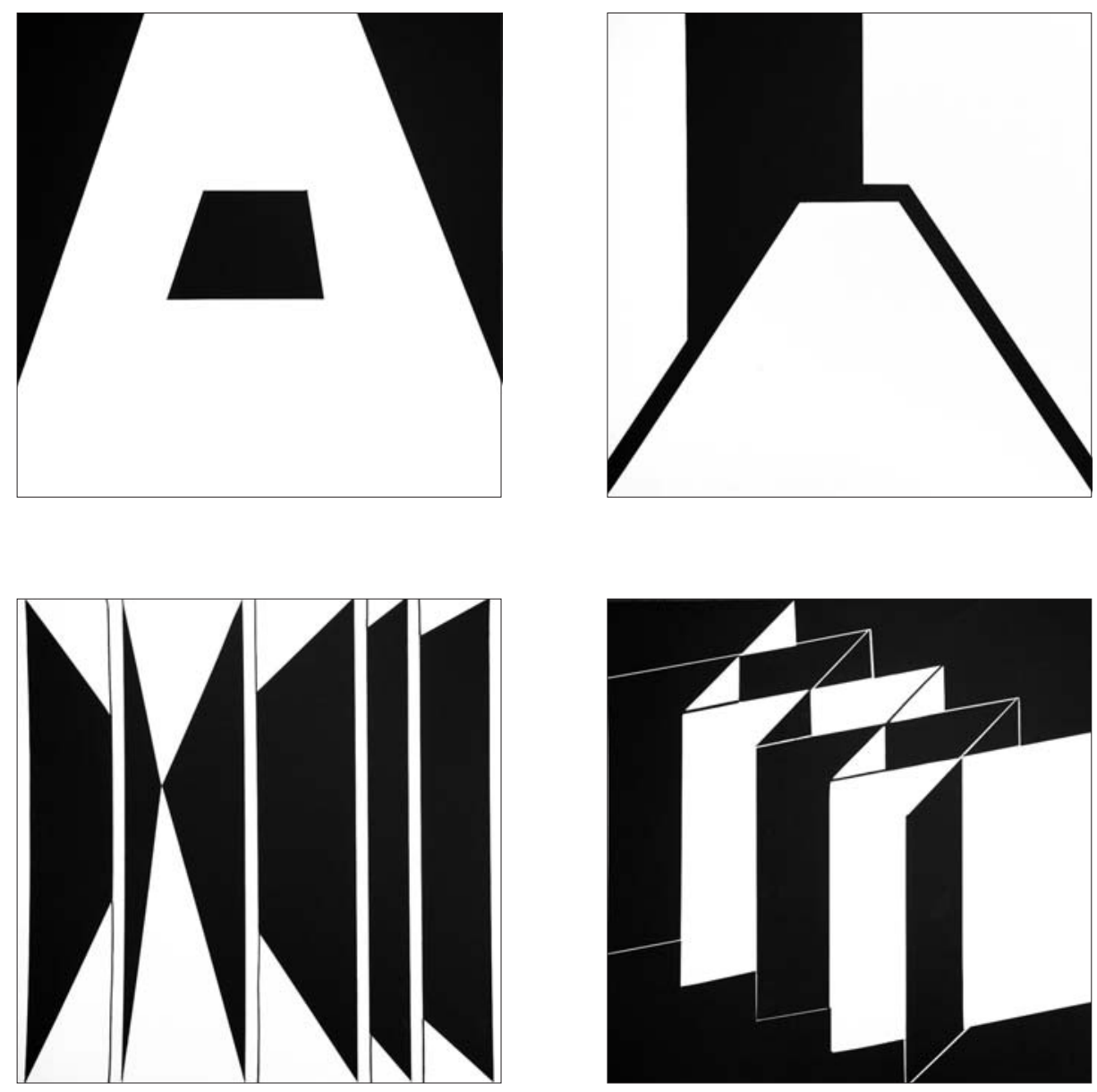

Inês Nunes

Inês Nunes 


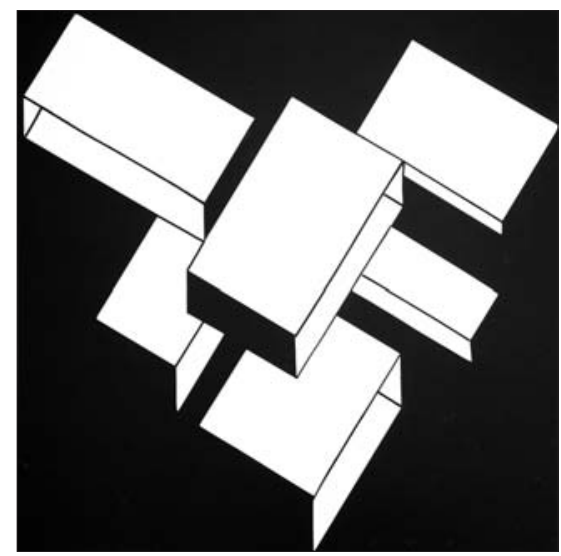

Inês Nunes
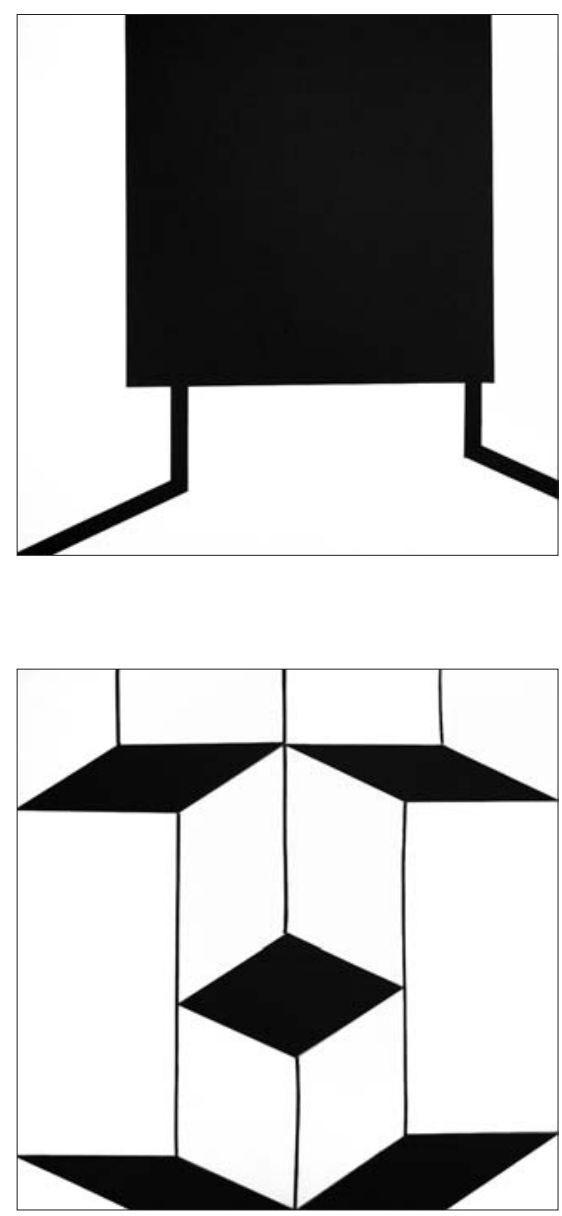

Vanessa Guerreiro

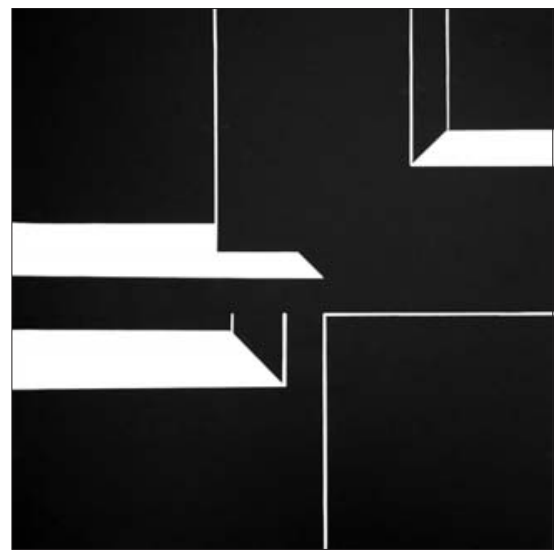

Ana Oliveira

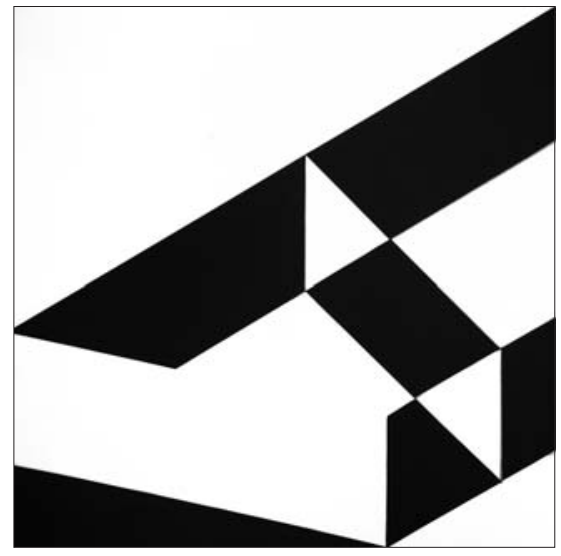

Vanessa Guerreiro

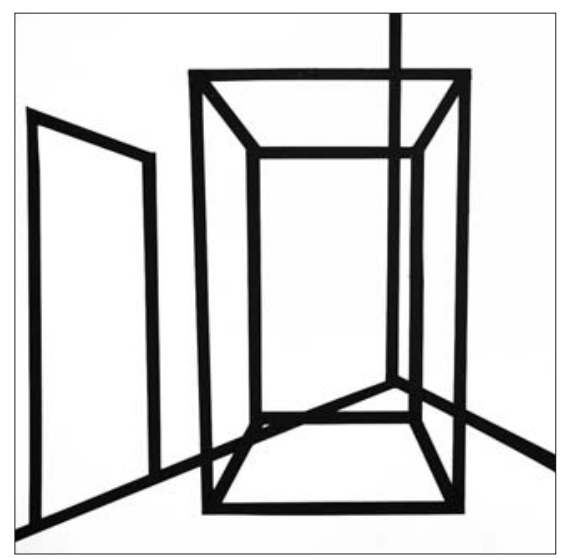




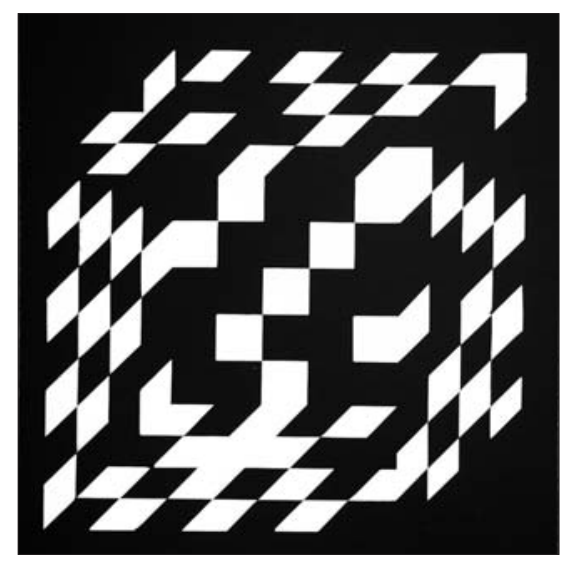

Mical Pinheiro

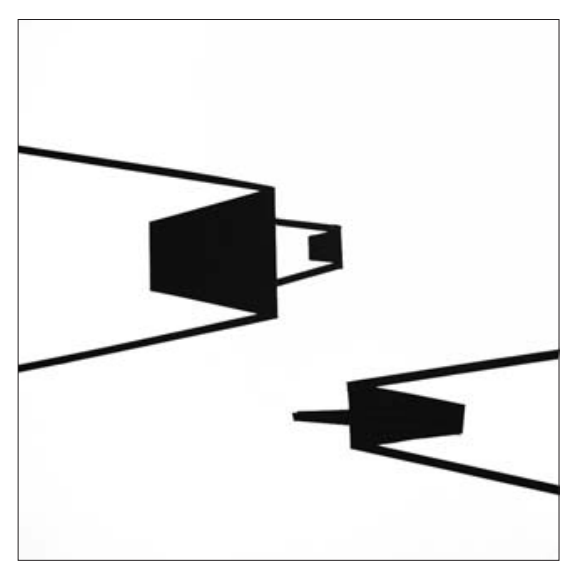

Bruno Branco

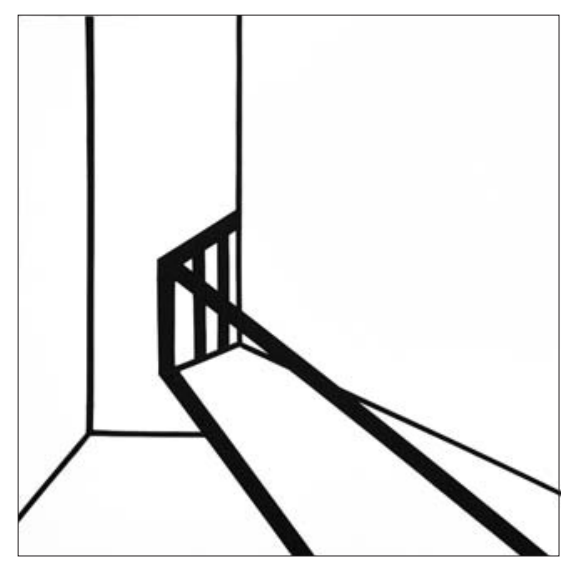

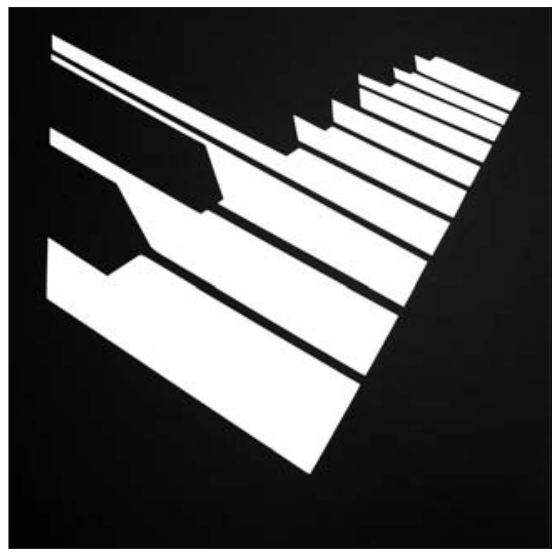

157
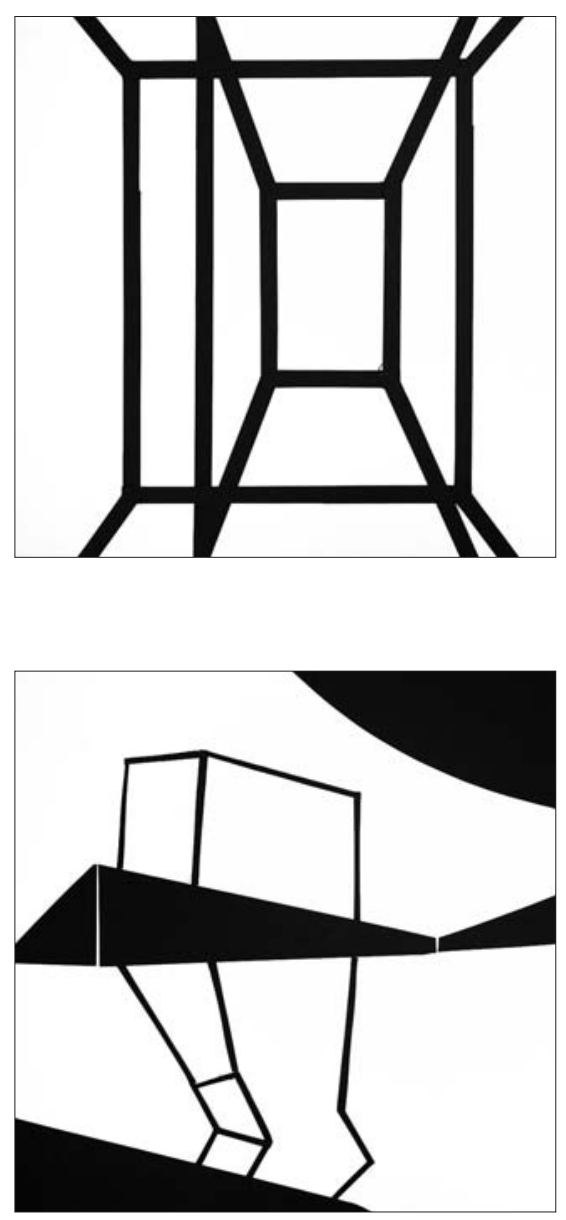


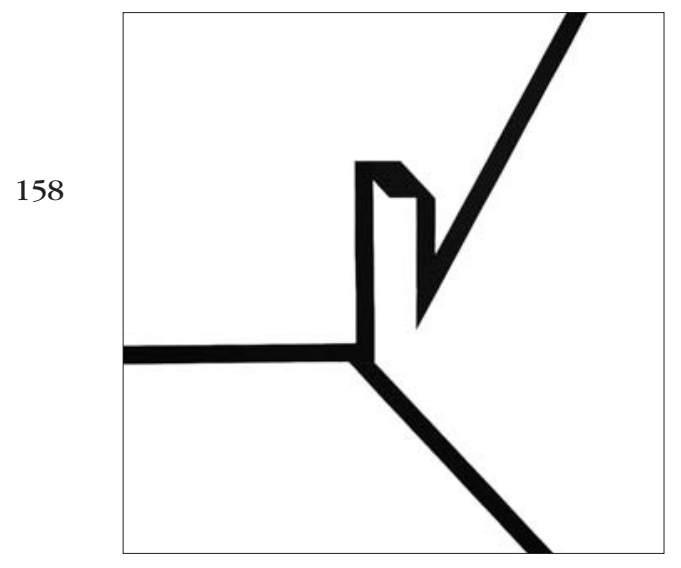

André Oliveira

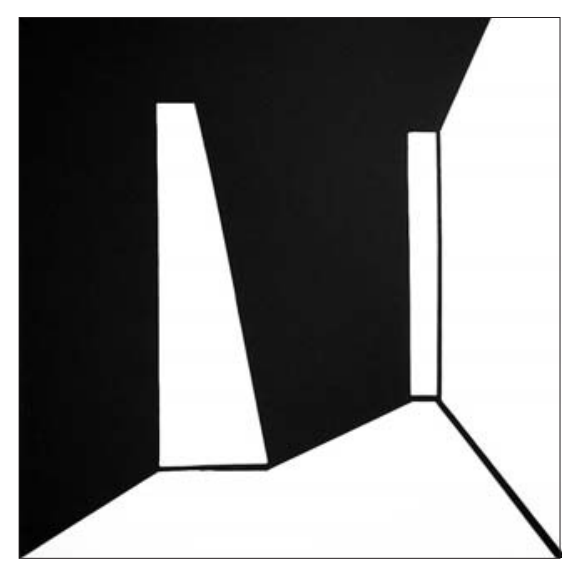

Jorge Correia

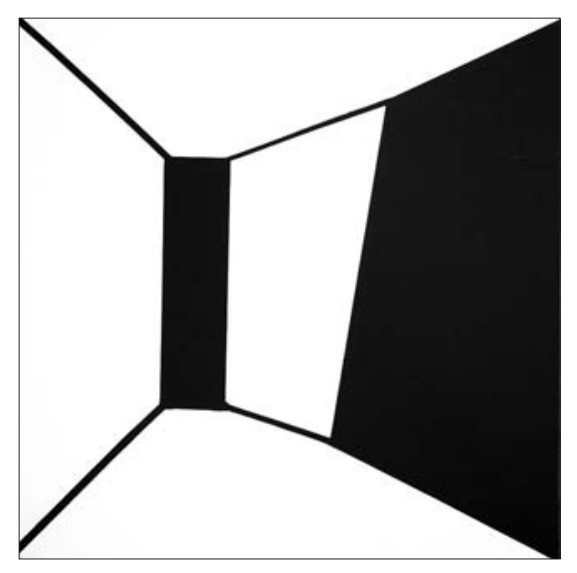

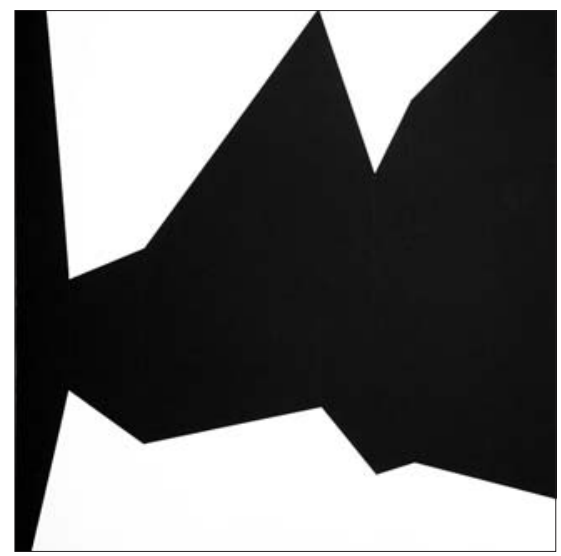

André Oliveira

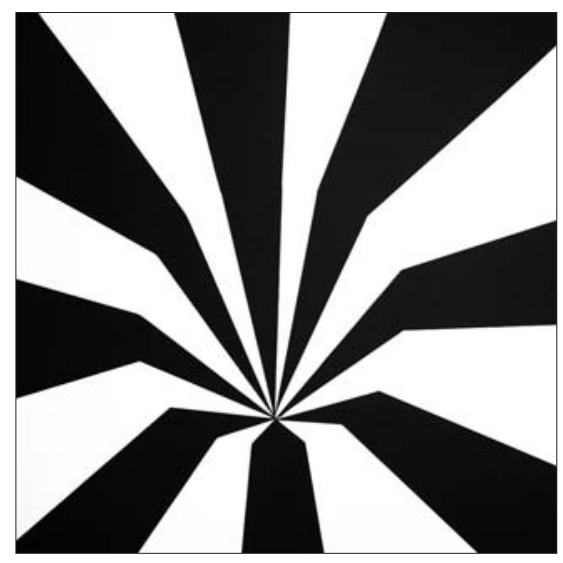

Paula Bernardino

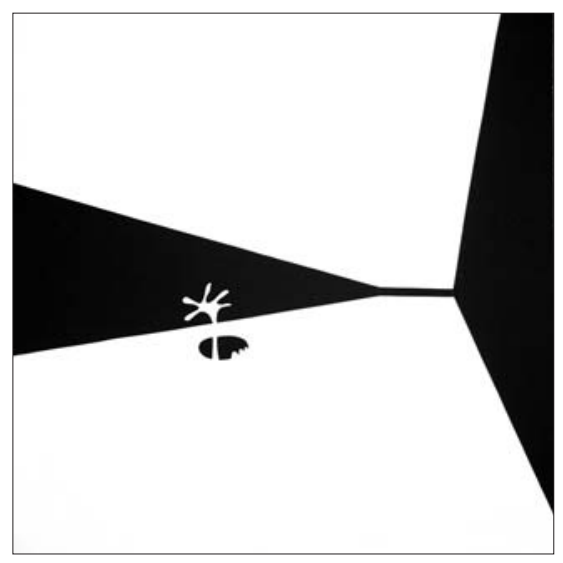

Maria Joana Sobral 


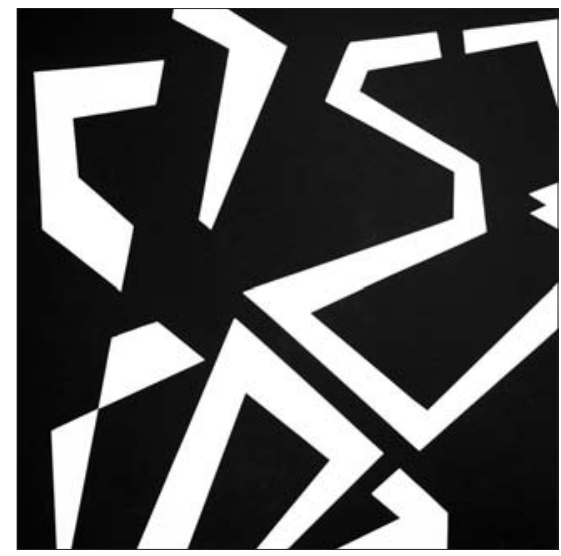

Liliana Coutinho

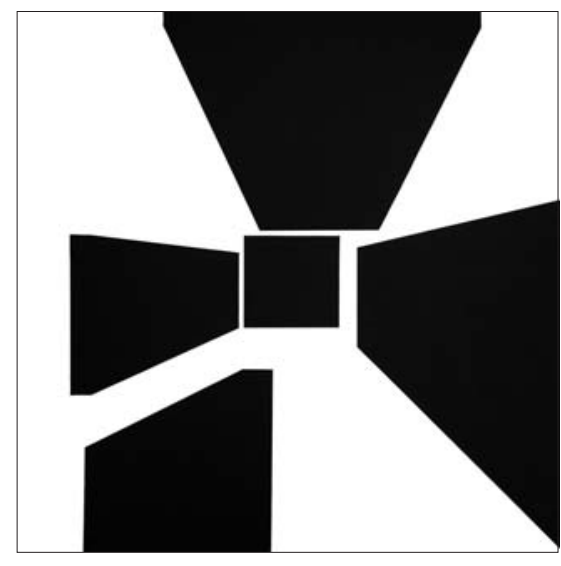

Vera Domingues

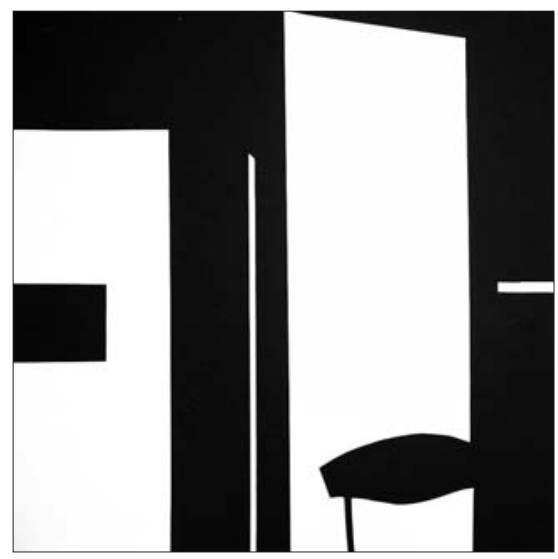

Rita Garcia

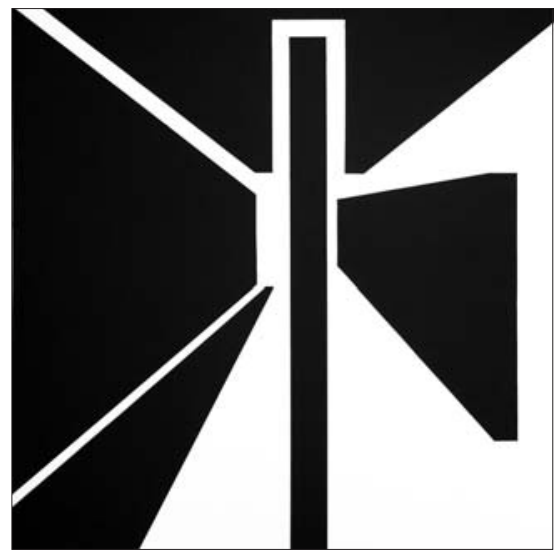

Vera Domingues

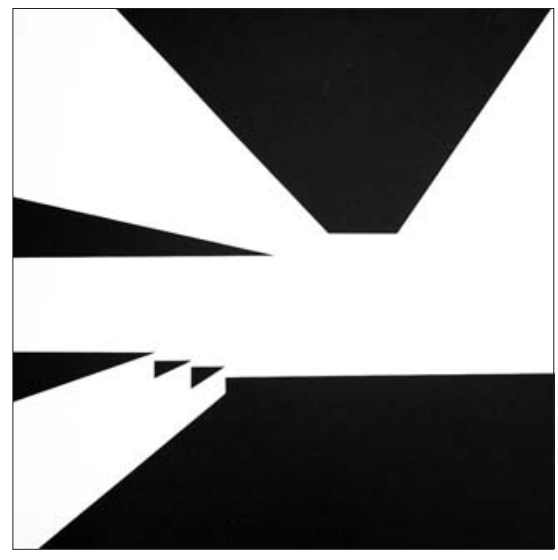

Rita Garcia

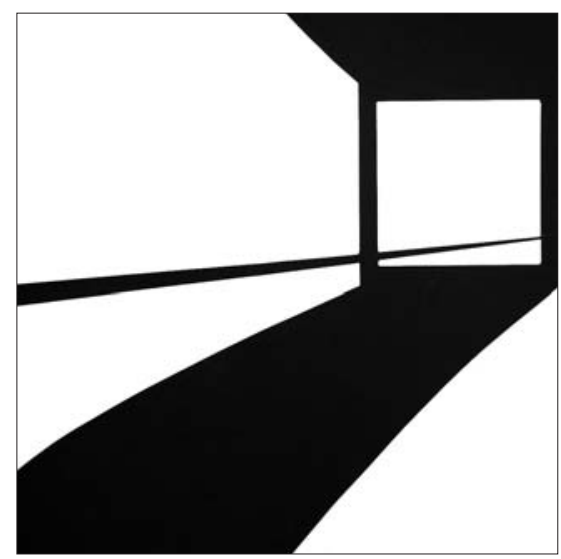

Rita Garcia 
160

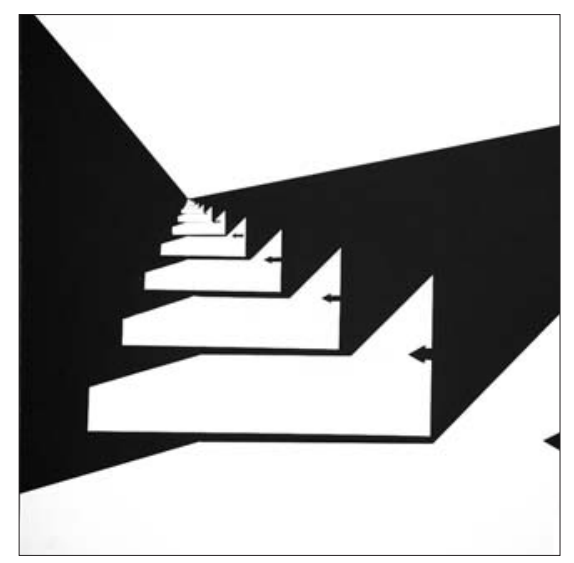

Tiago Garcia

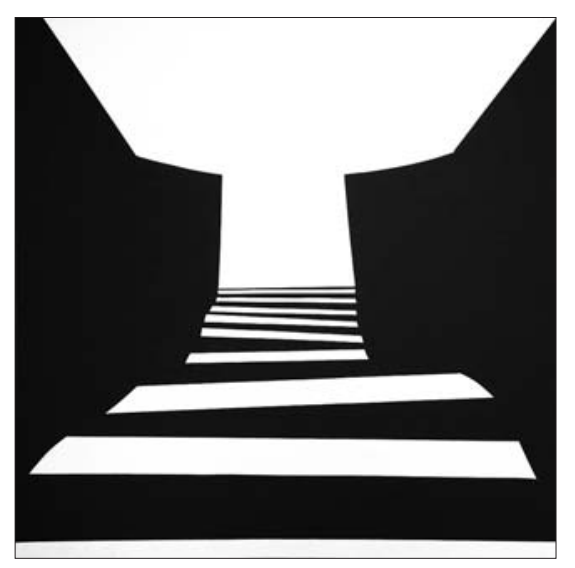

Tiago Garcia

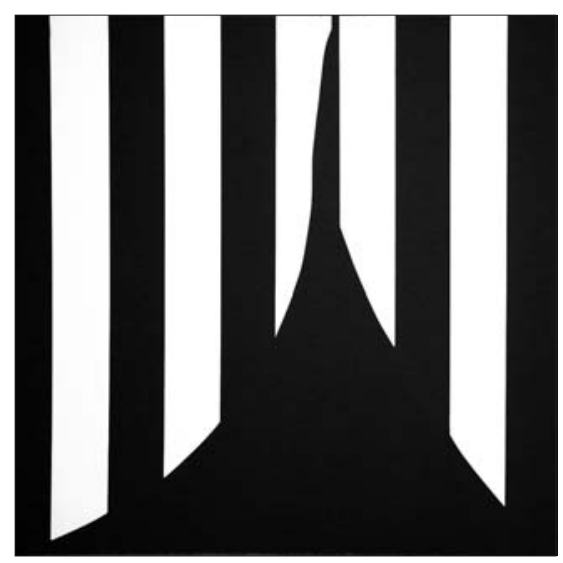

Carla Abreu

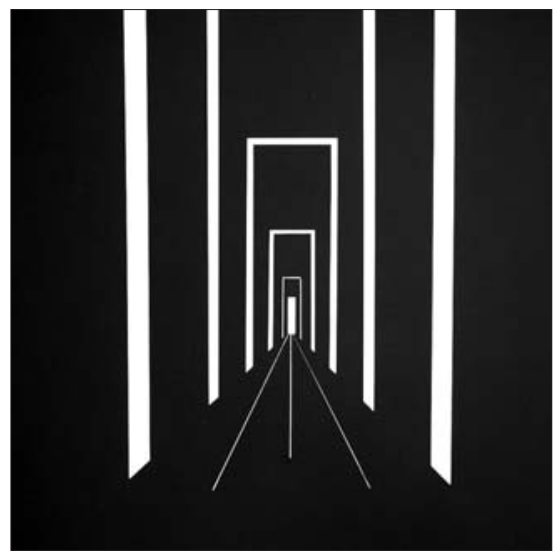

Ângela Tacão

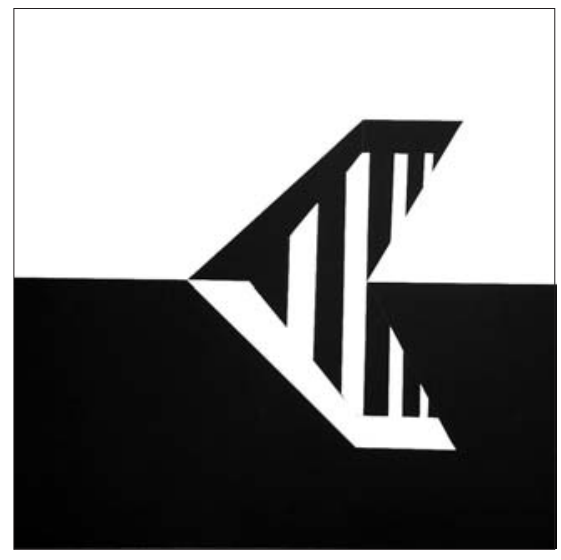

Ana Maria Feijão

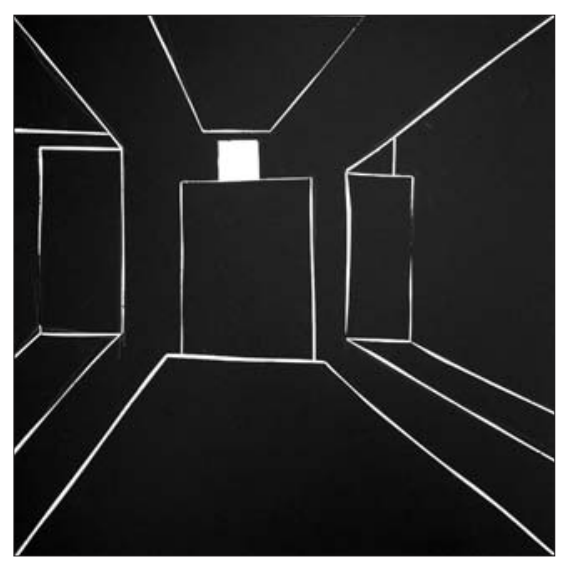

Ana Ferreira 


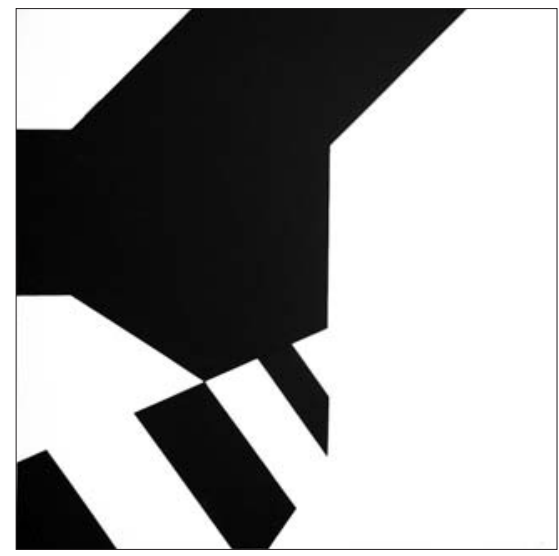

Joana Rita Ramos

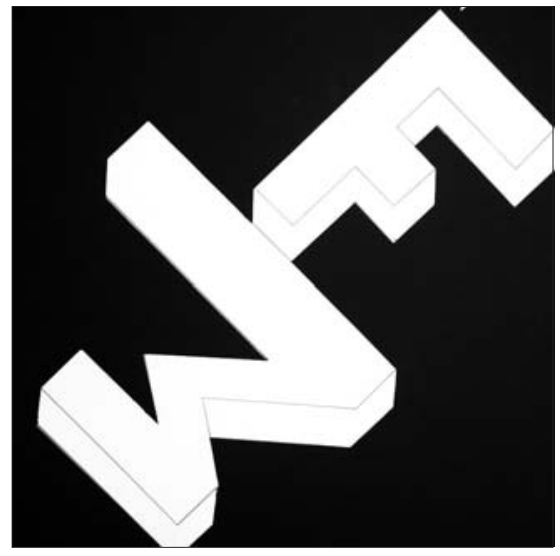

Wilfred Figueiredo

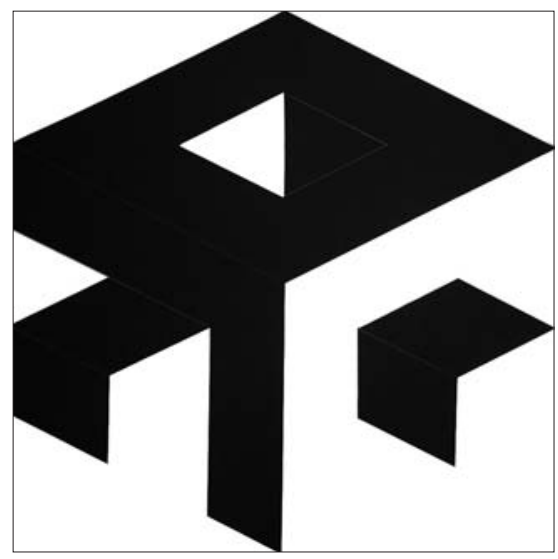

Wilfred Figueiredo

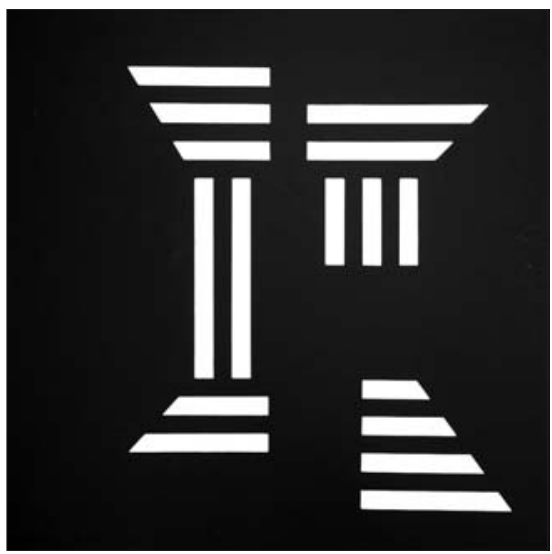

161

Joana Rita Ramos

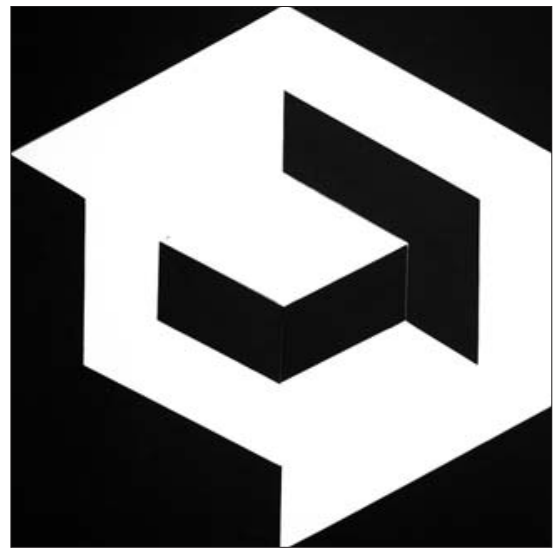

Wilfred Figueiredo

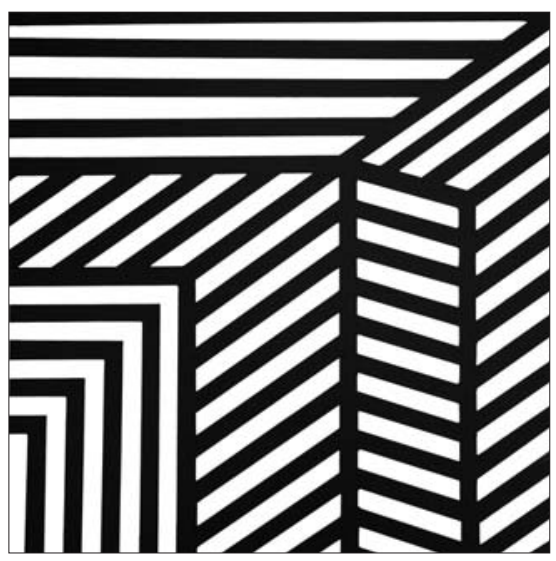

Joana Rita Ramos 
(Página deixada propositadamente em branco) 
EXPLORAÇÃO DAS POTENCIALIDADES DE

TRANSFORMAÇÃO FORMAL DA ESTRUTURA DE UM CUBO 
(Página deixada propositadamente em branco) 
A partir da forma de um cubo realizar desenhos sucessivos onde este seja transformado noutras formas, sendo essa transformação motivada pela própria estrutura do cubo e não por lhe acrescentar aleatoriamente elementos.

Sendo a estrutura do cubo o principal ponto de partida para a gestação formal, aqui é encarada a criatividade como um processo de desenvolvimento como se o cubo, pela sua estrutura, já possuísse em si a potencialidade de se transformar.

Assim, a criatividade reside na capacidade de intuir potenciais metamorfoses na forma ponto de partida.

Aqui a invenção formal não se orienta pela mera adição de formas, explorando as potencialidades da forma original. 


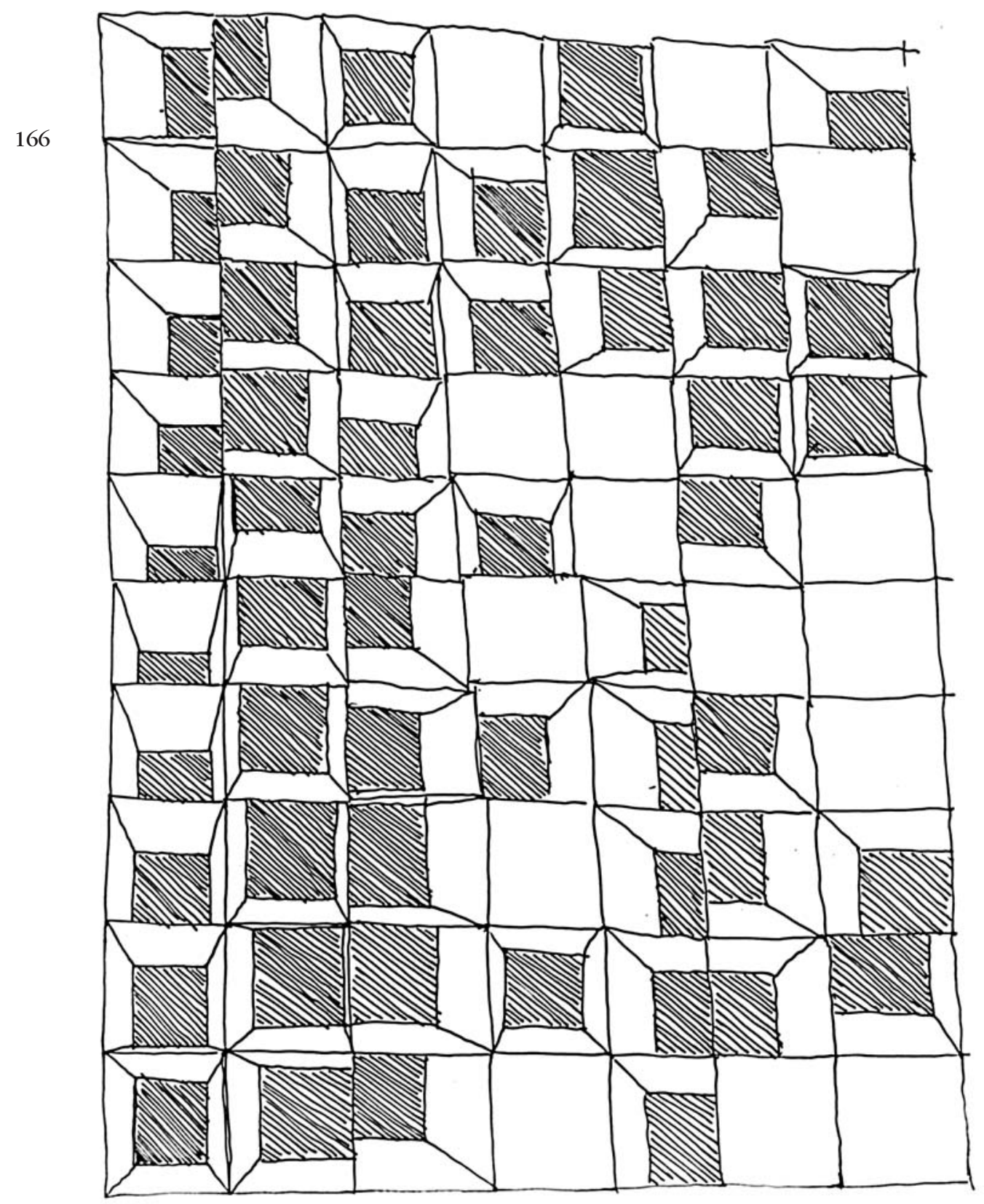




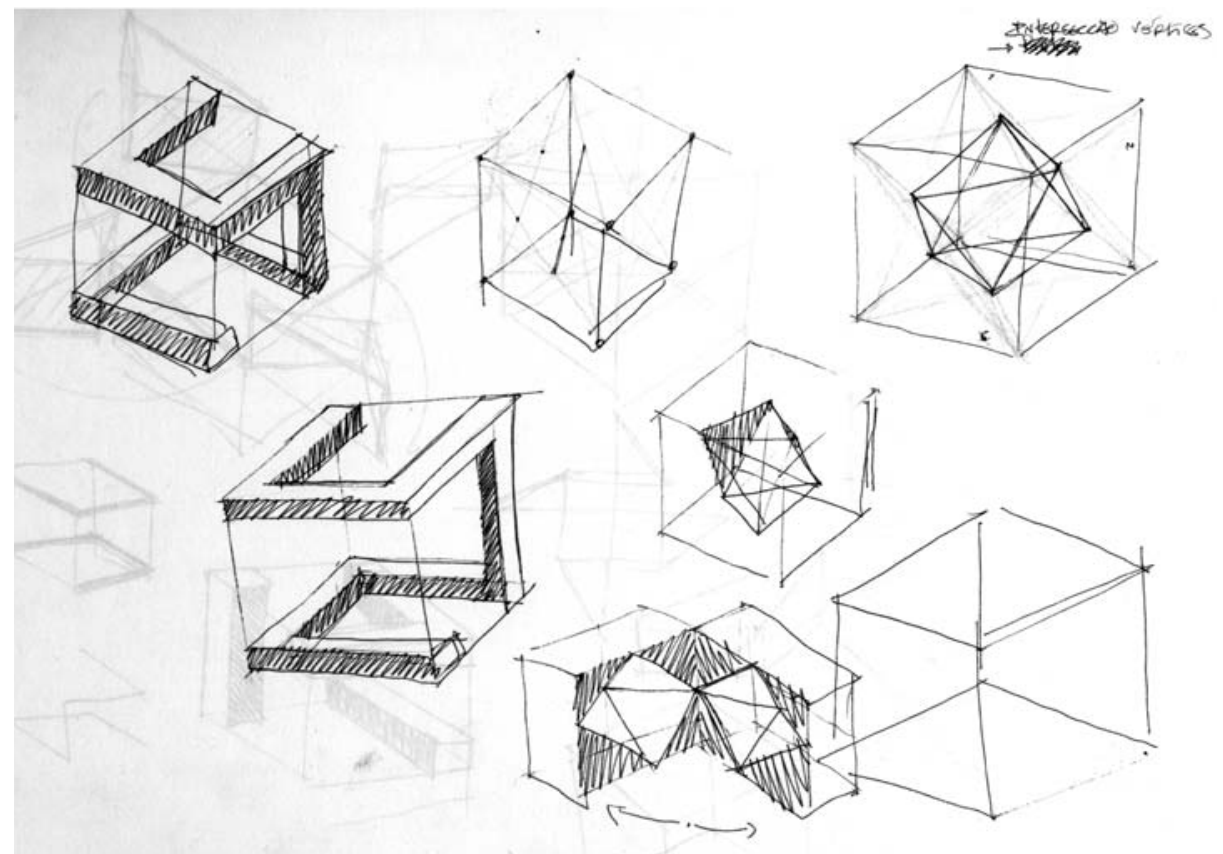

Je= D.B.

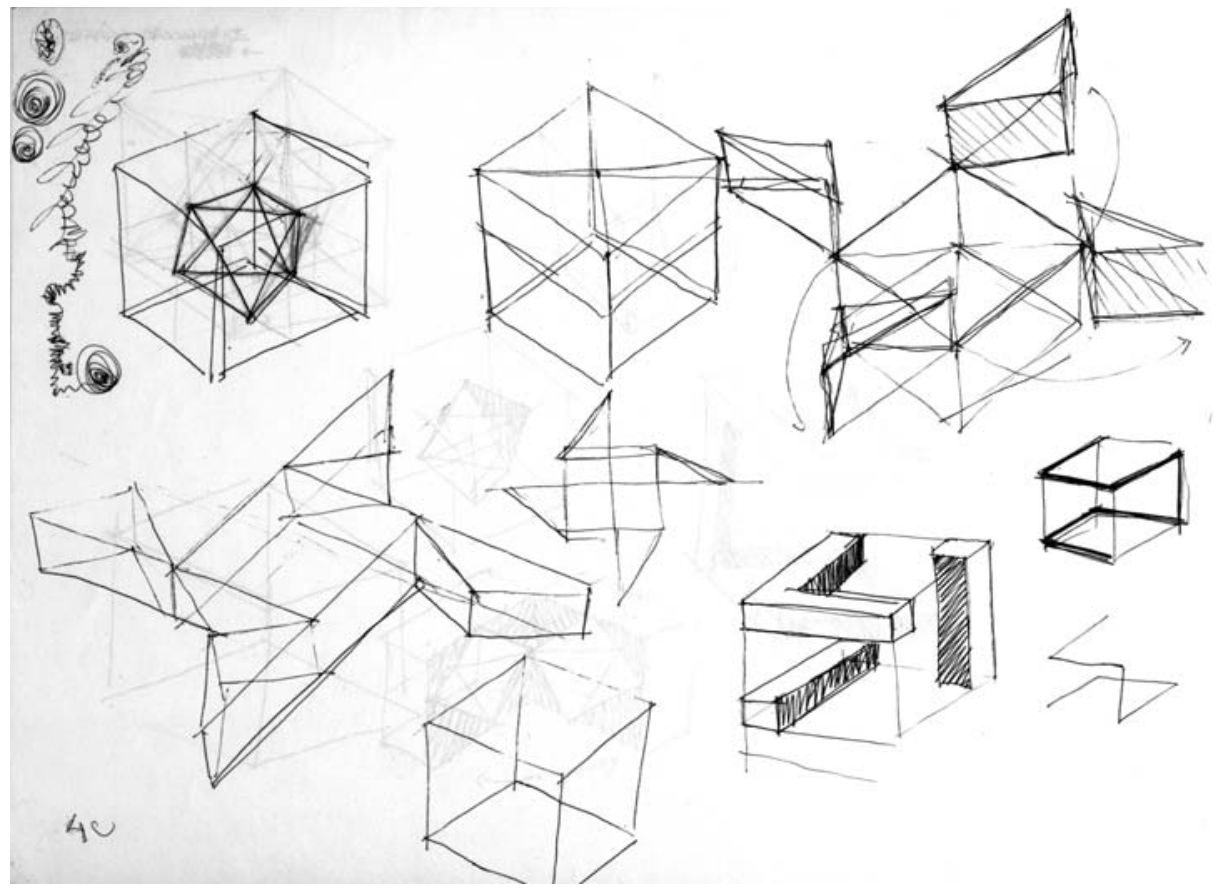


168
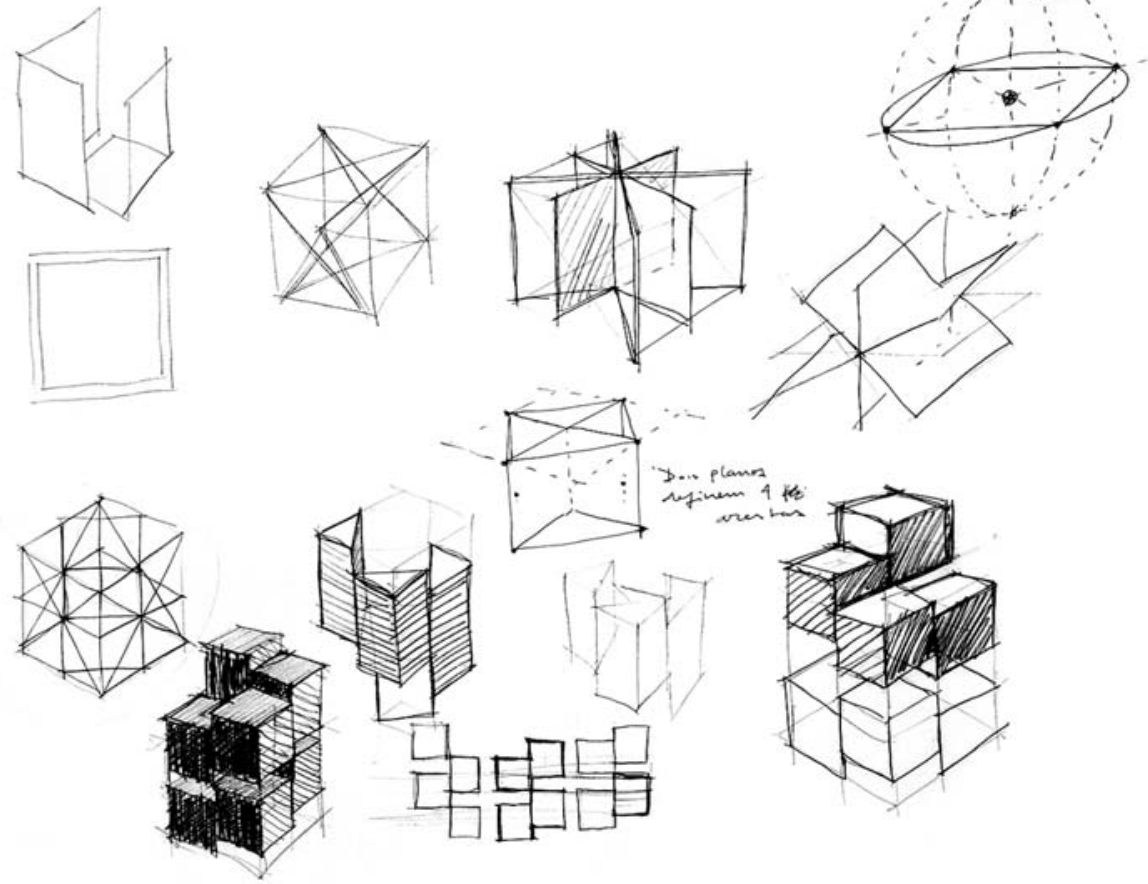

... pland

Tiago Lança

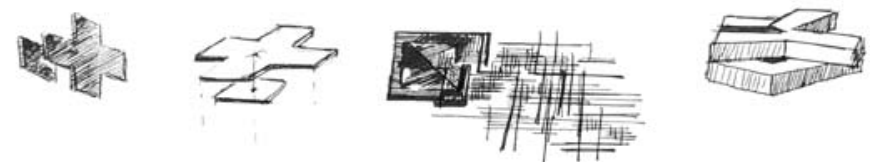

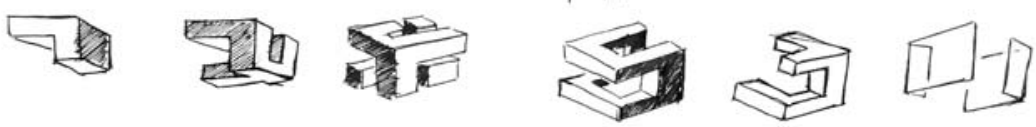

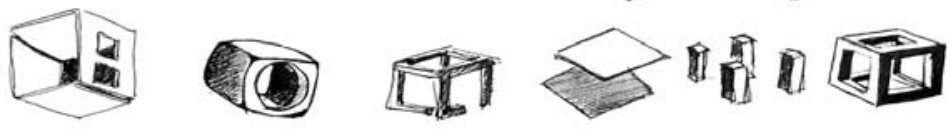

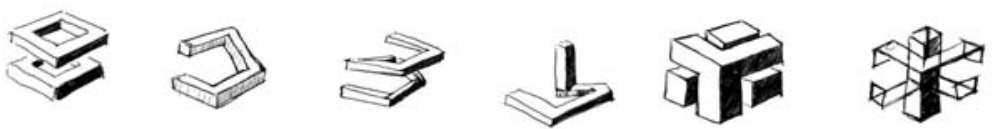



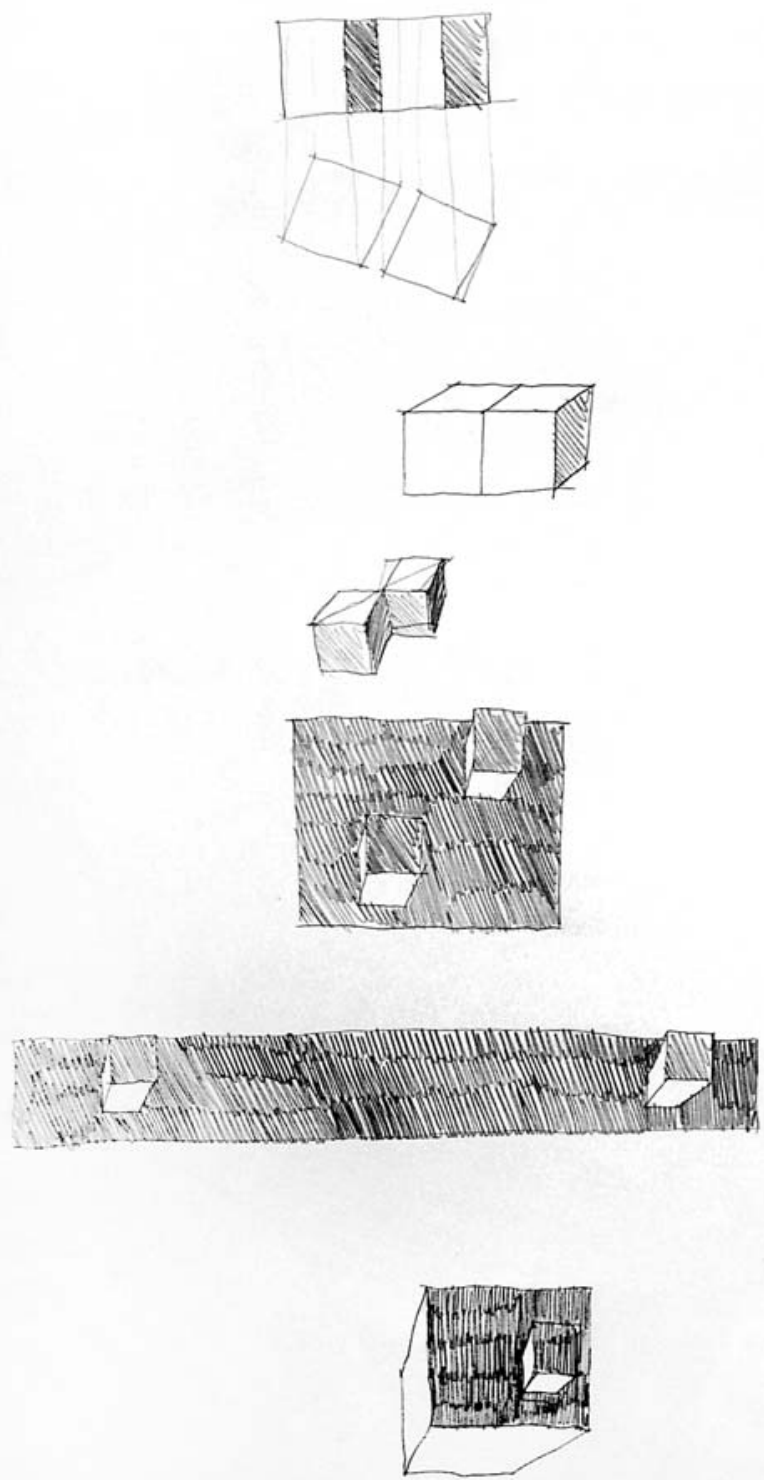

17. 1.00 
170

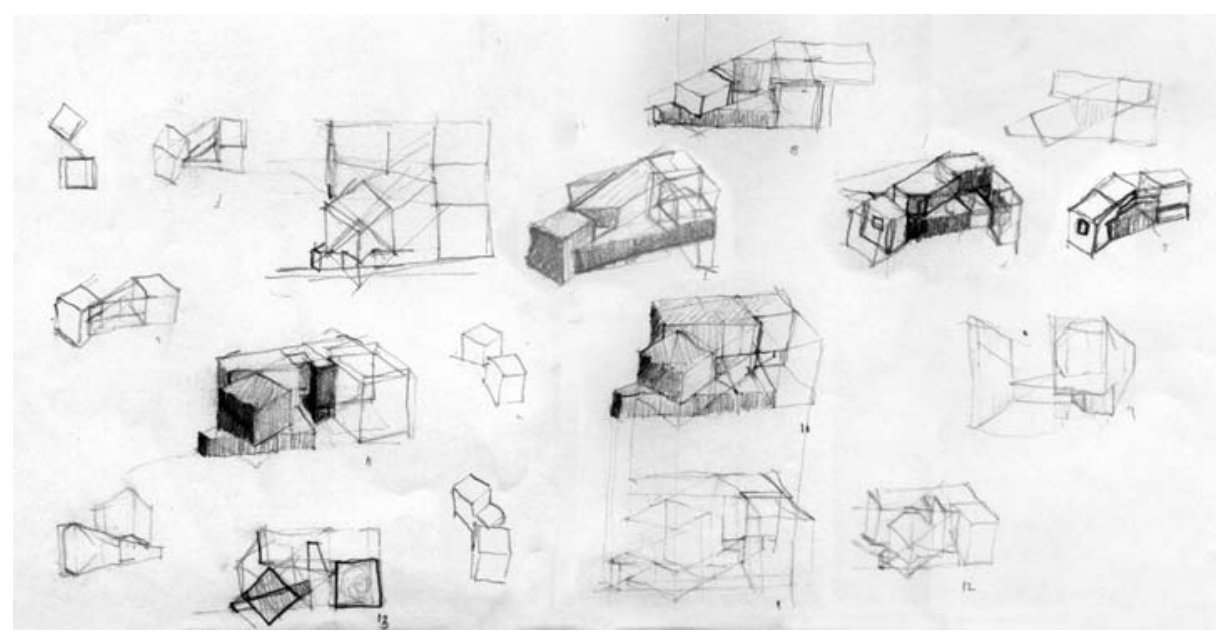

Helder Ferreira
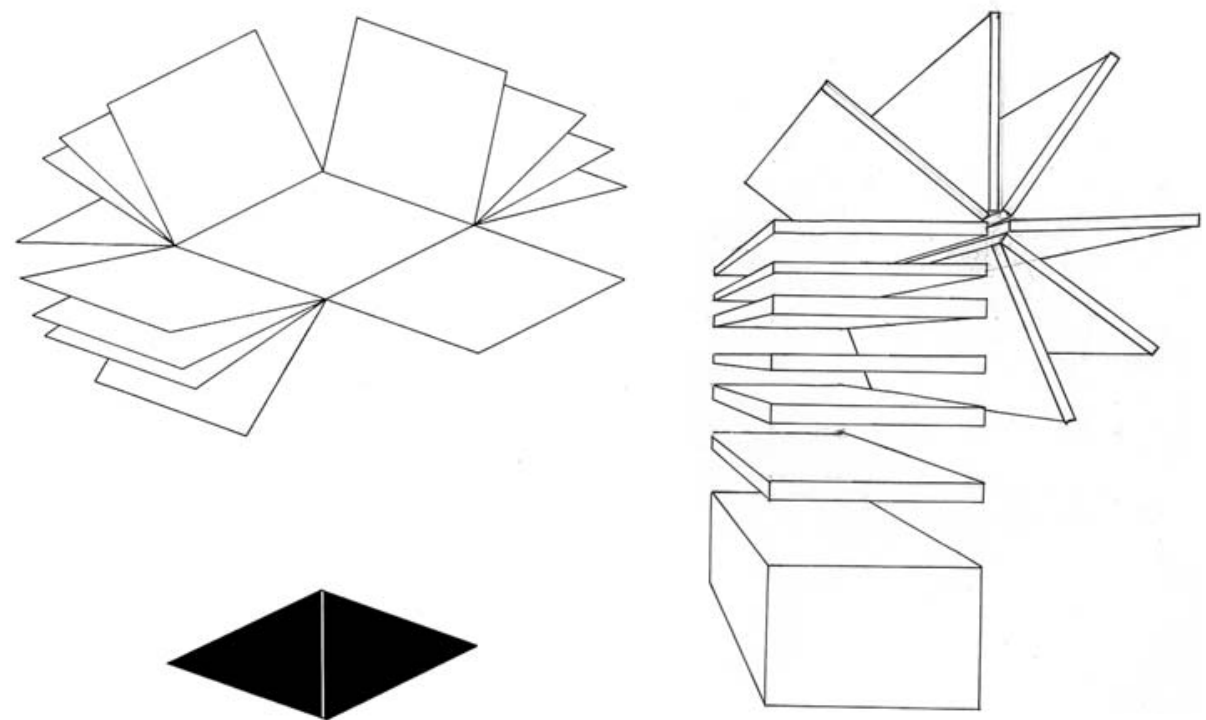

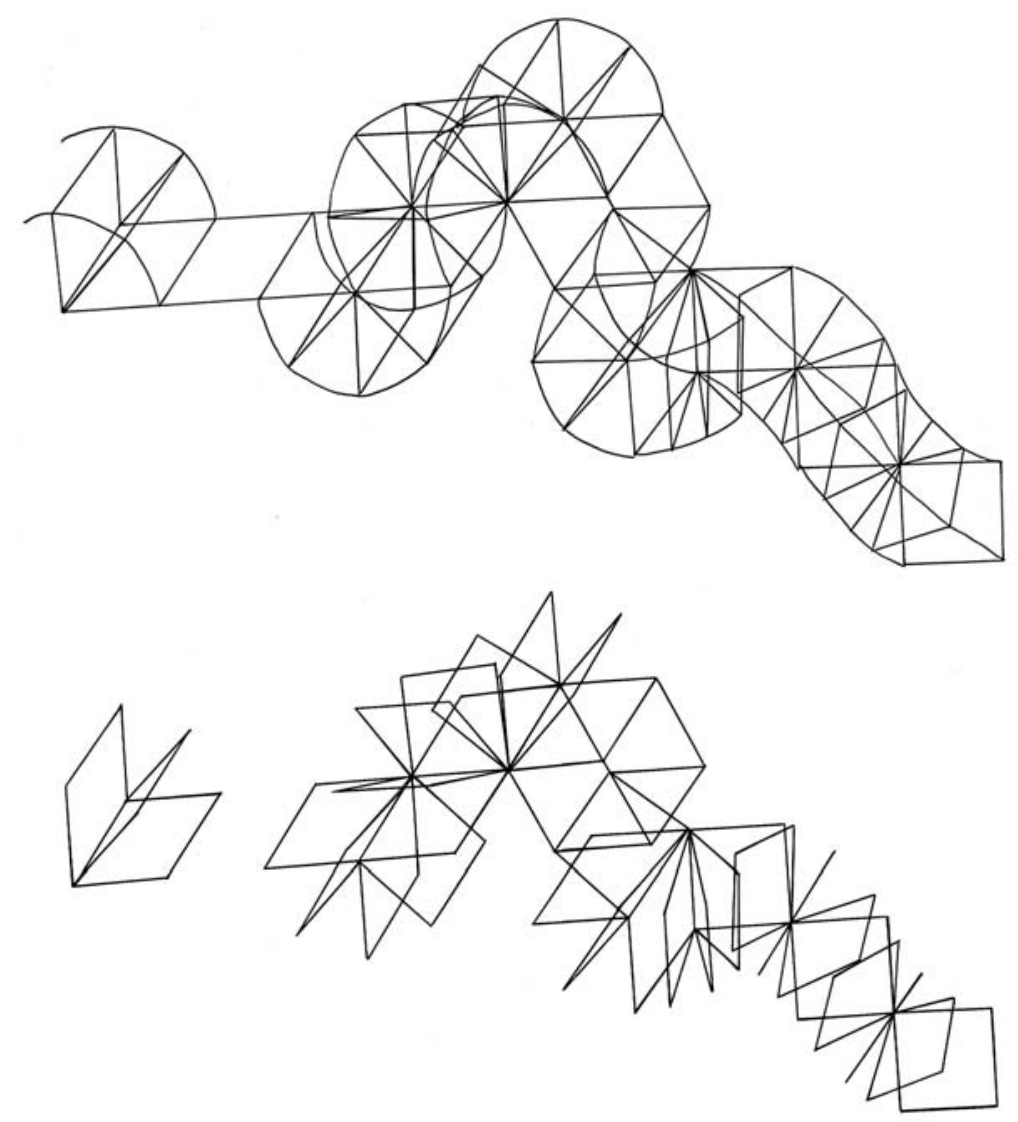

Carina Fonseca

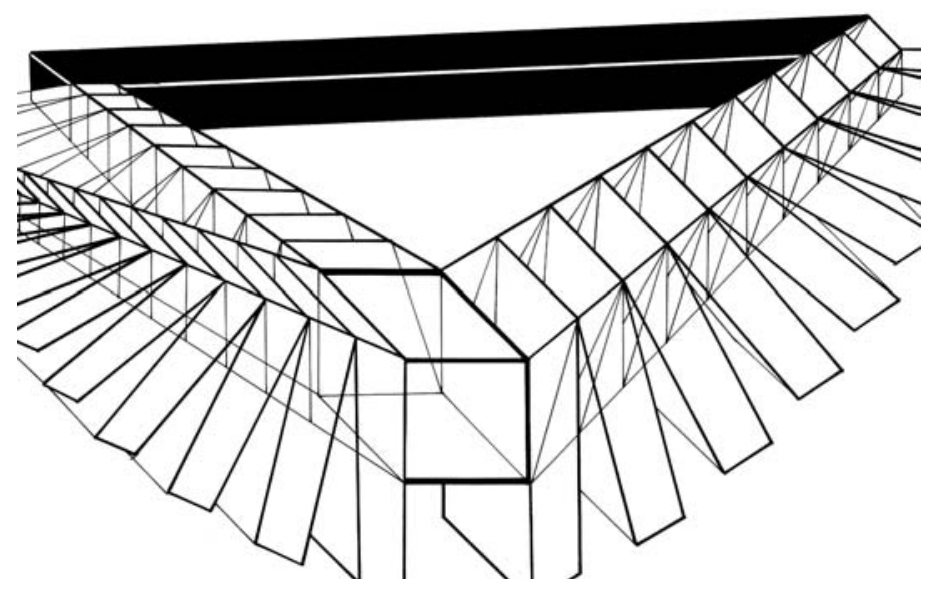

Susana Martins 


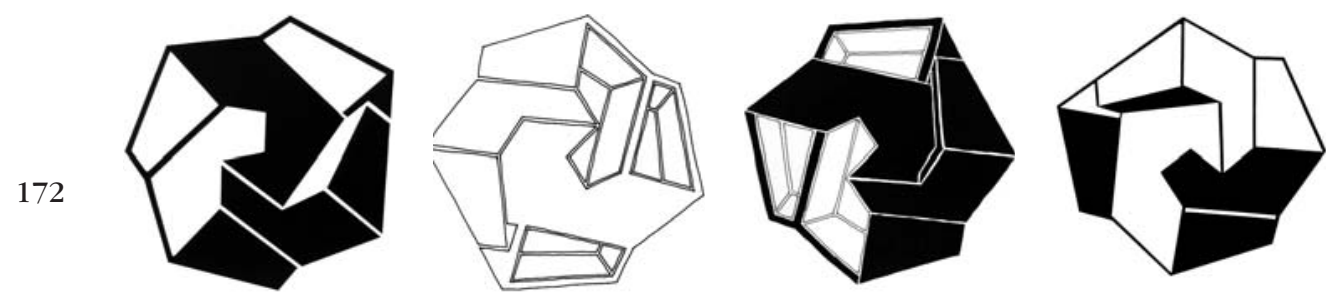
João Castanheira
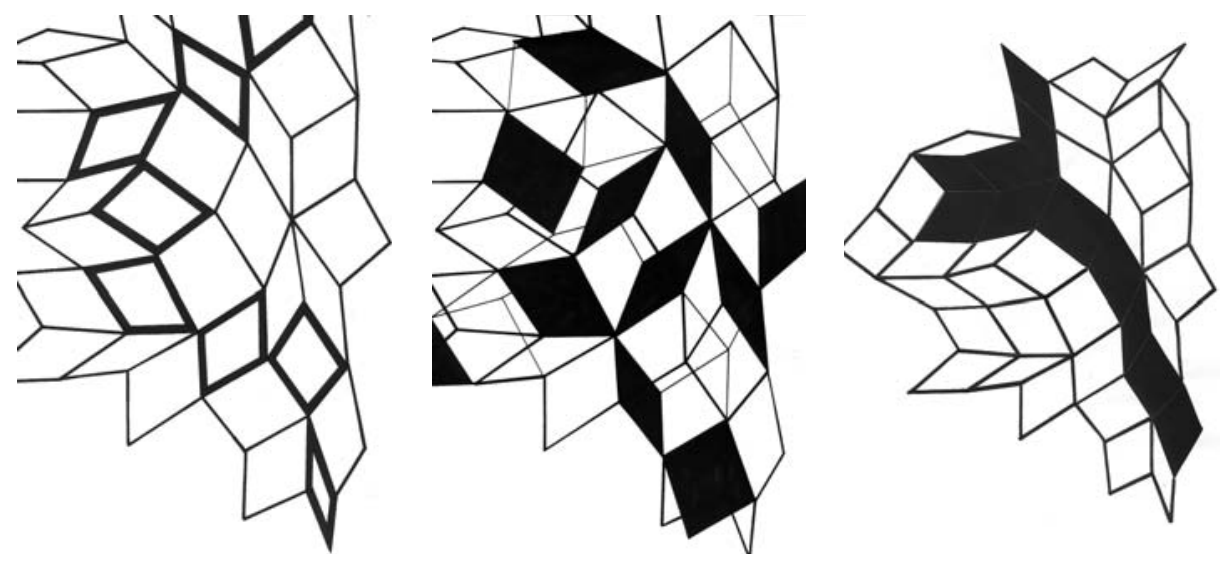

Jeremias Nascimento
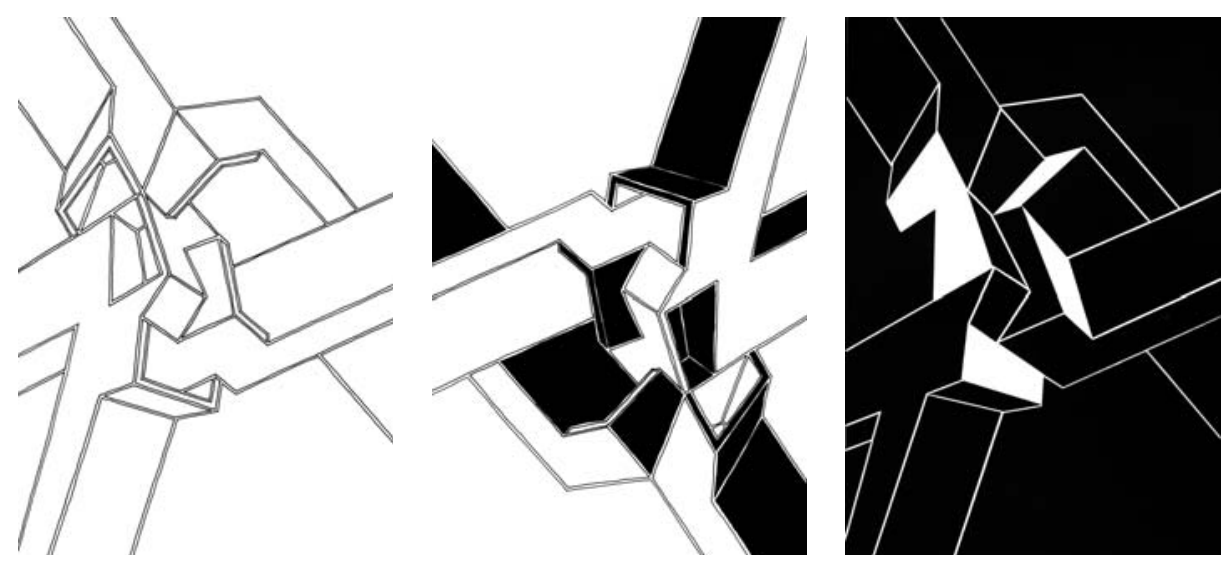

João Castanheira 

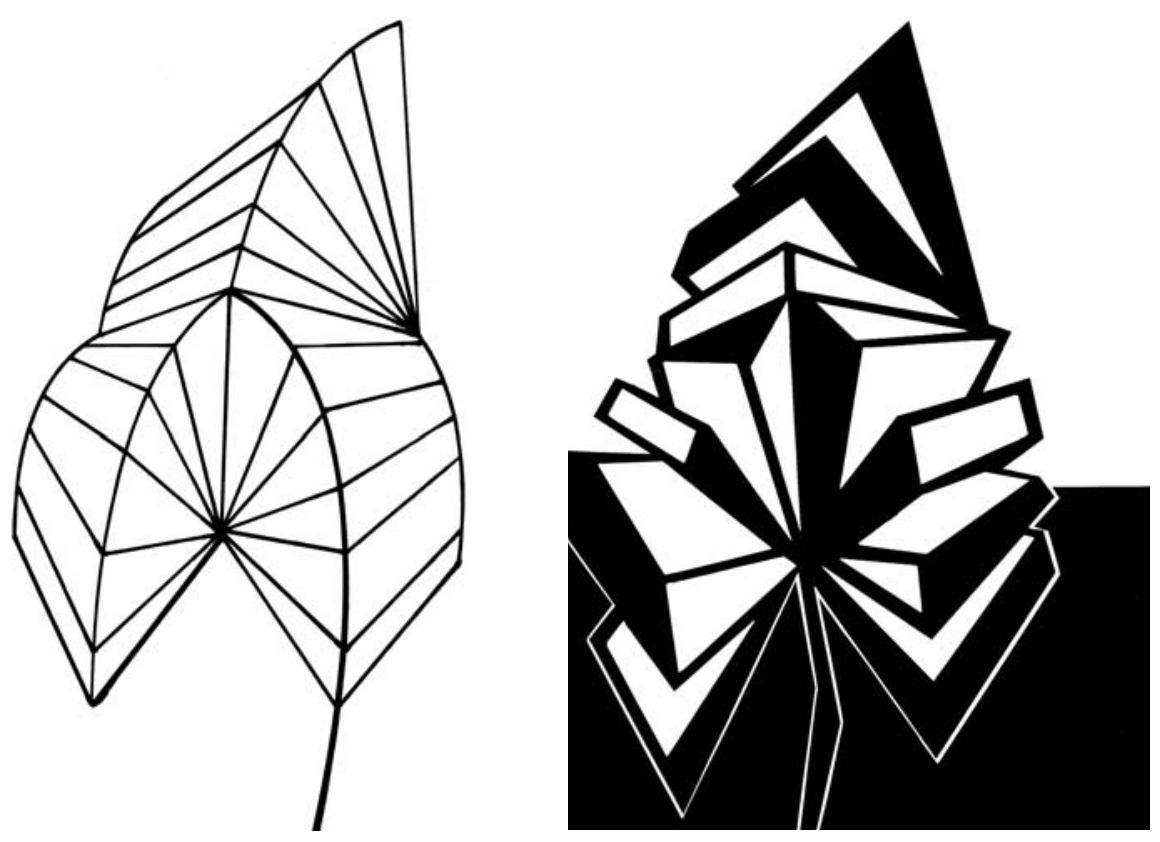

173
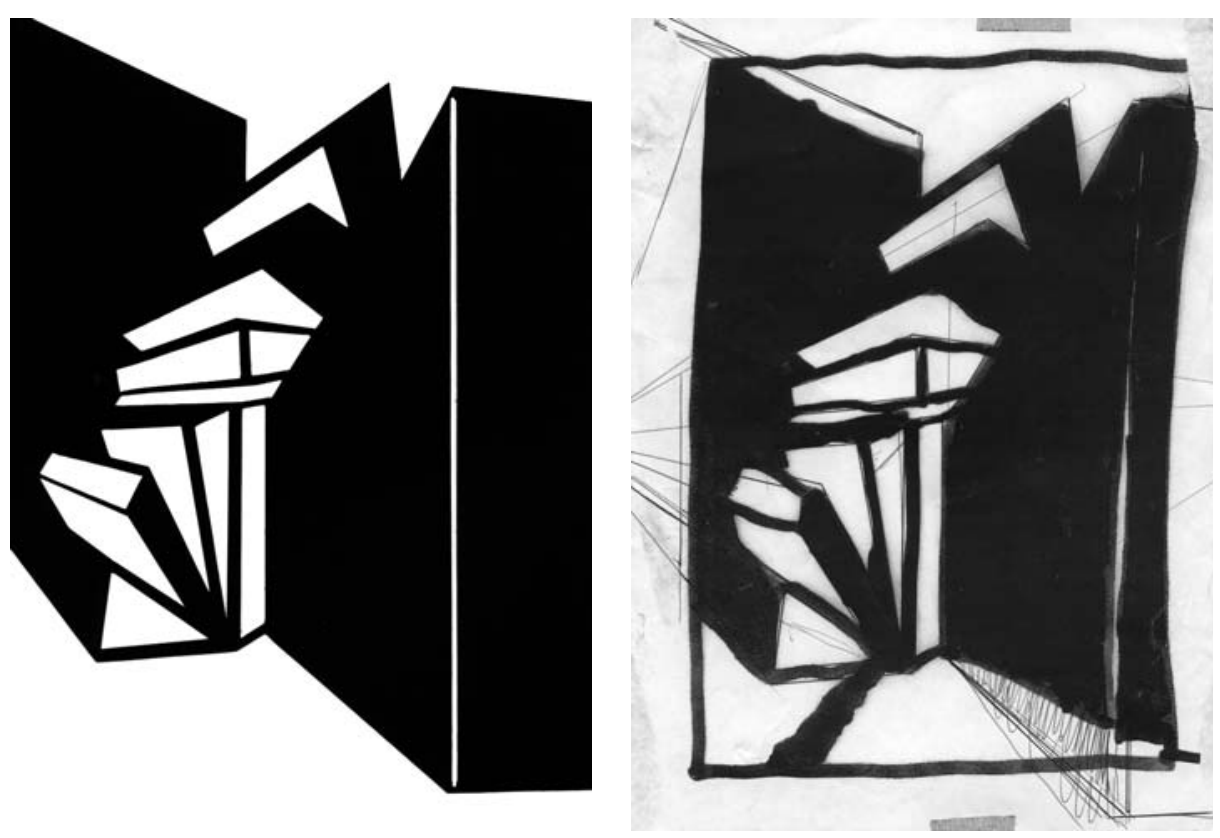

João Crisóstomo 

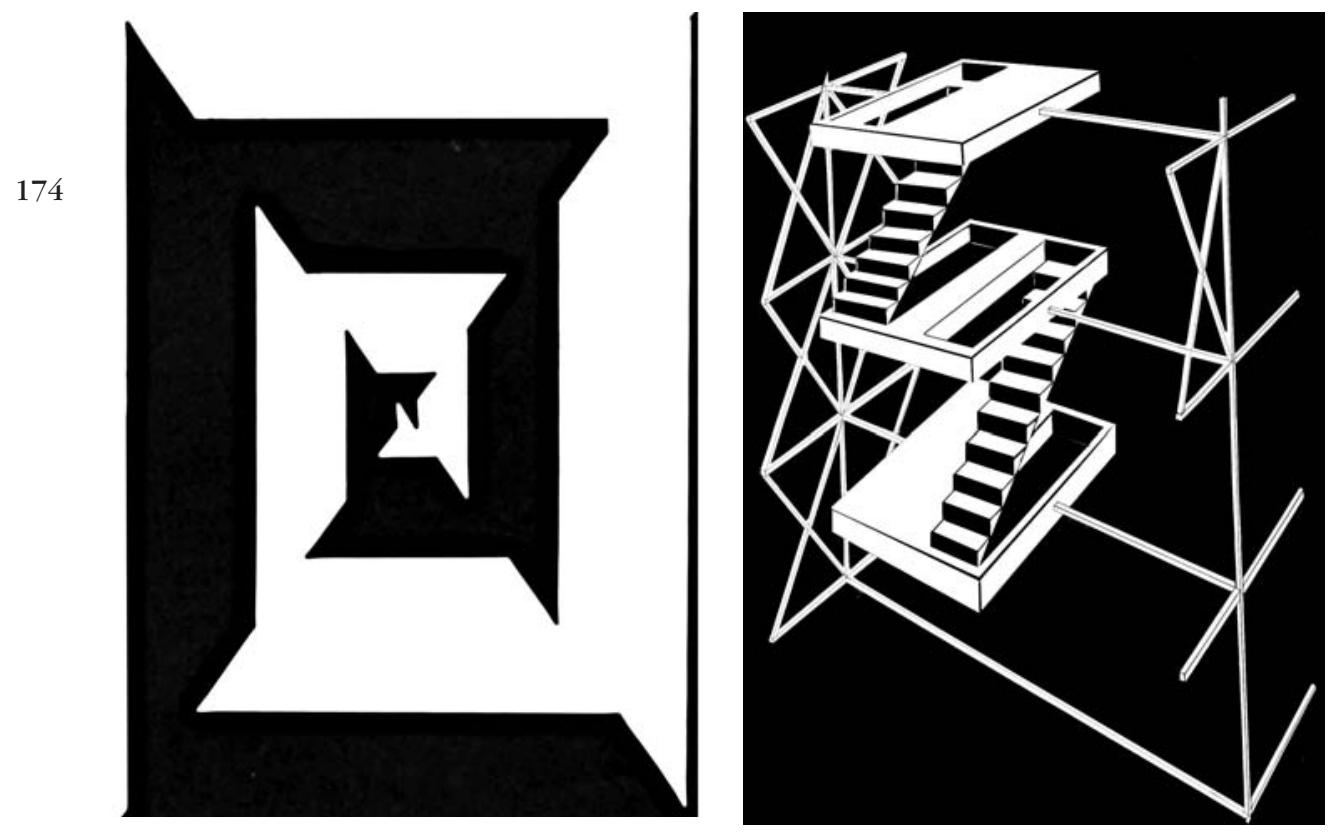

Luís Loureiro
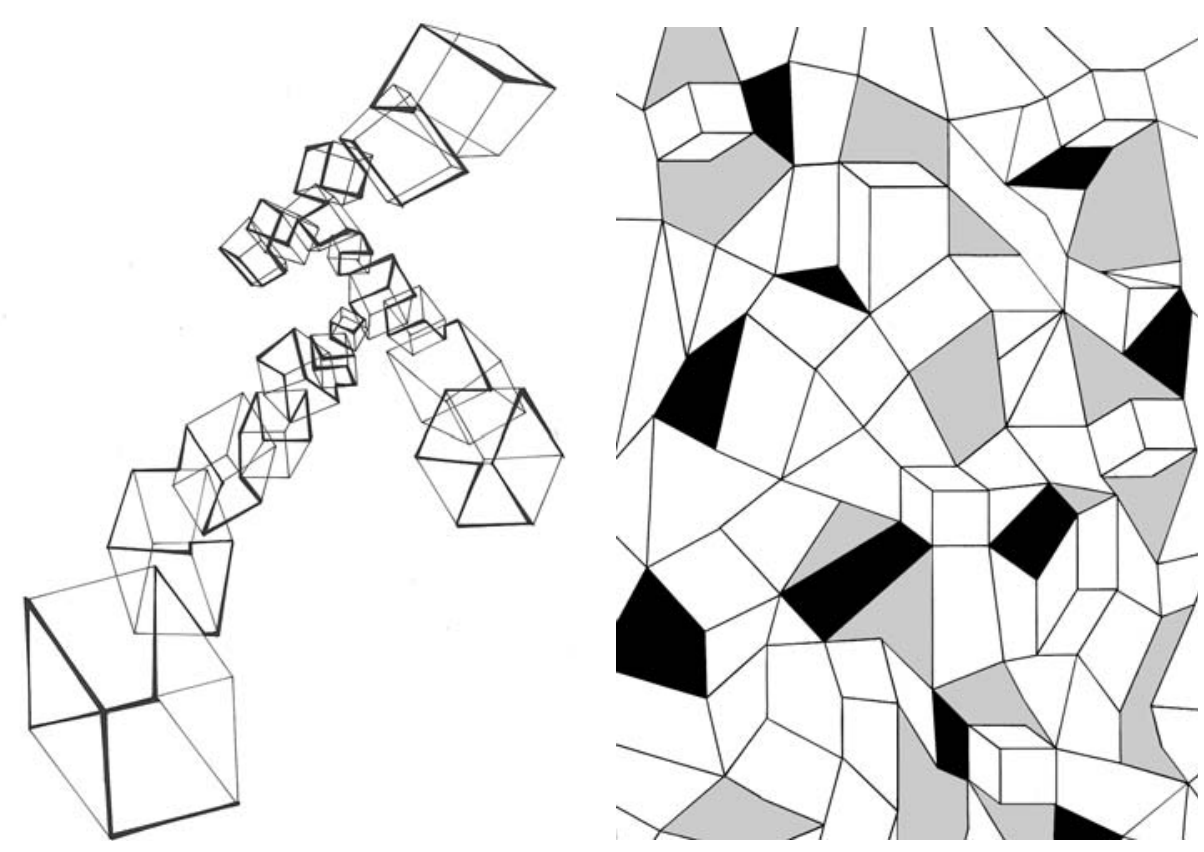

Mafalda Mourão 


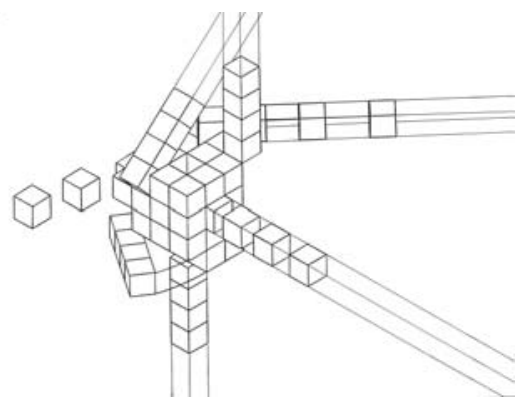

Nuno Gaspar

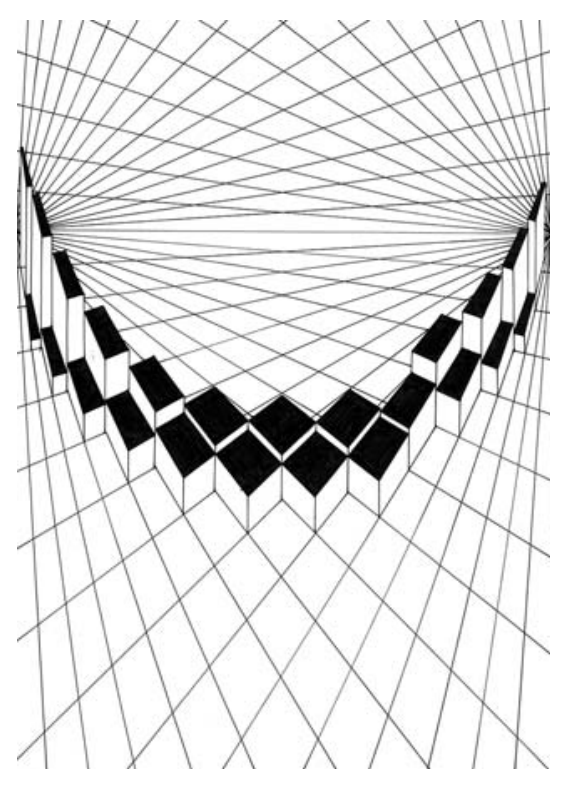

Susana Martins

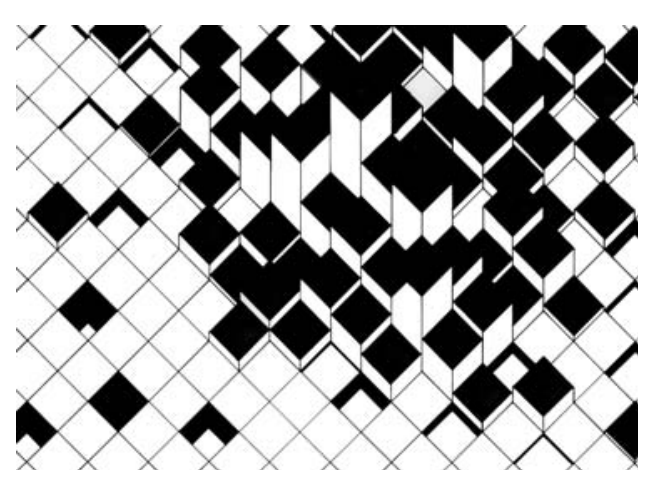

Daniel Pires

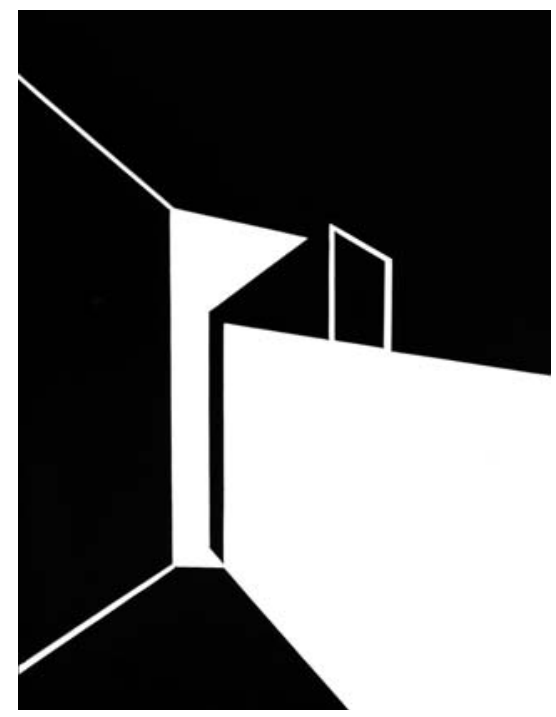

175

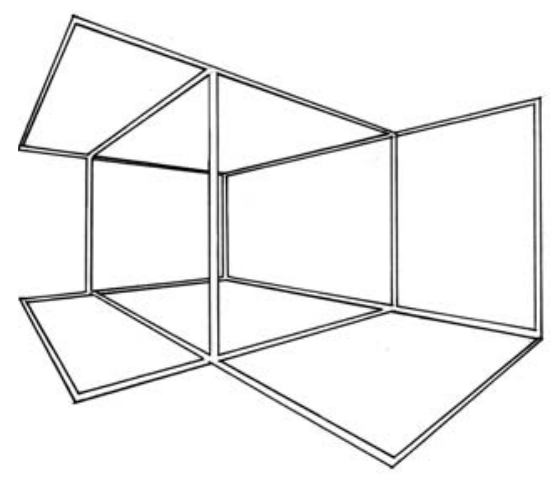

Marco Godinho

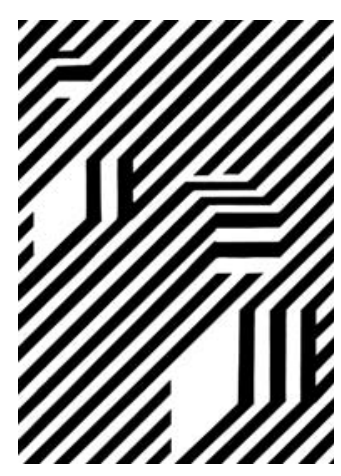

Daniela Silva 


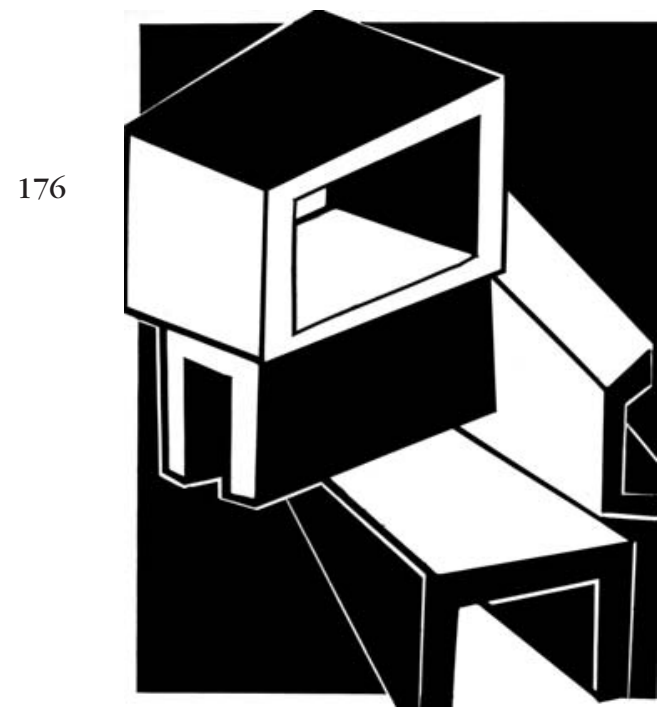

Luís Sobral
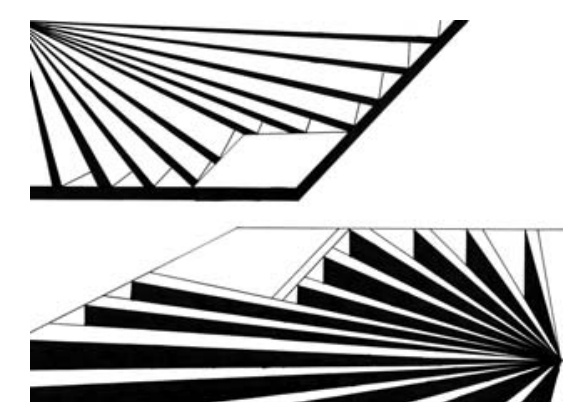

Andreia Paixão

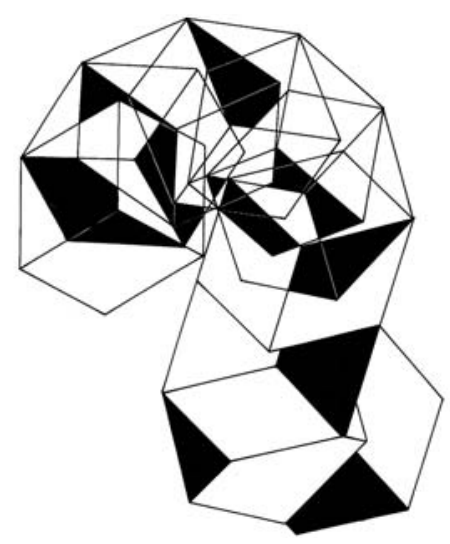

Ricardo Mendes

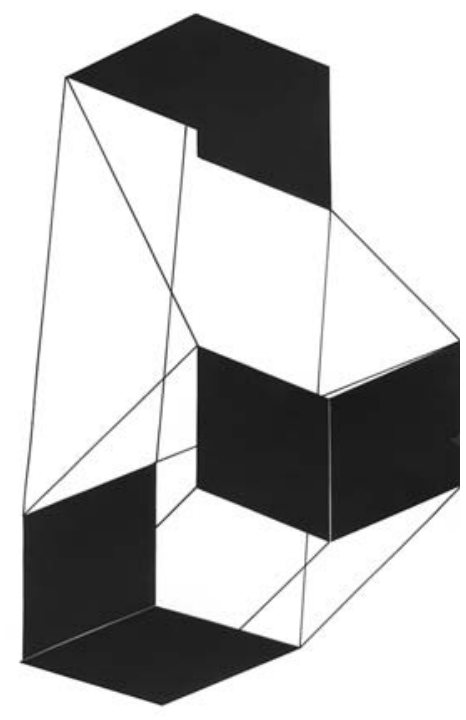

Luciano Ribeiro

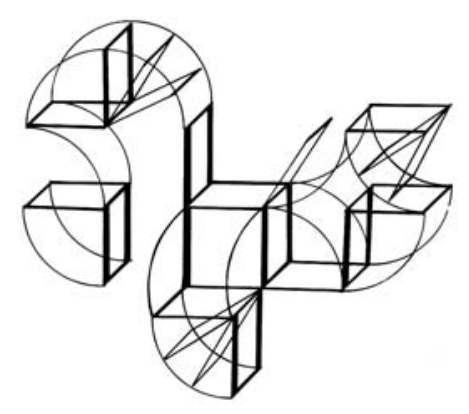

Marina Neves

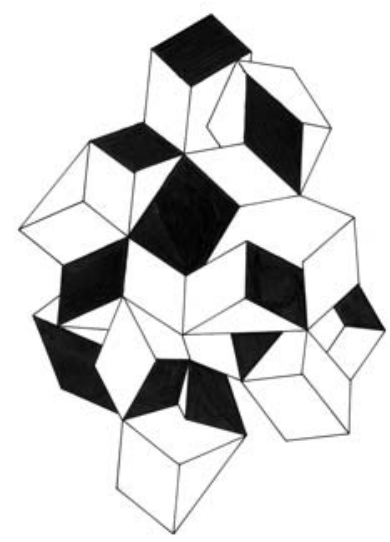




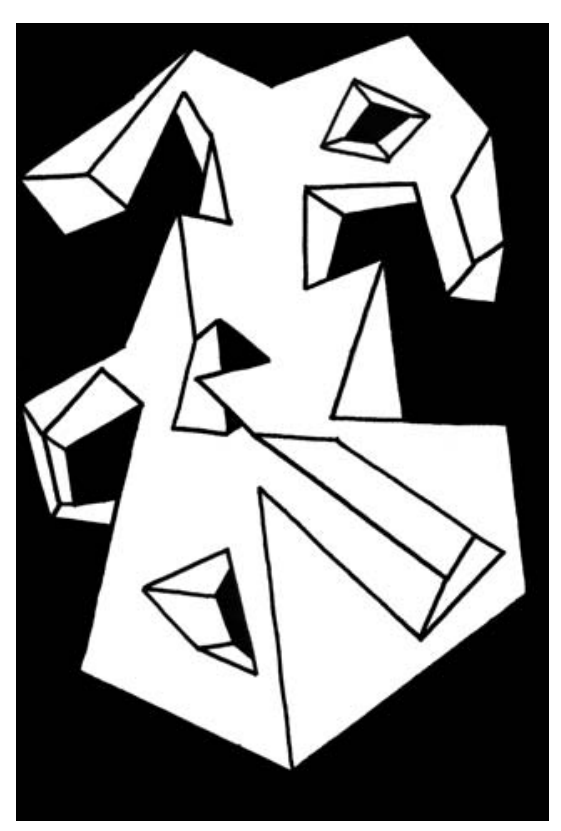

Filipa Alfaro

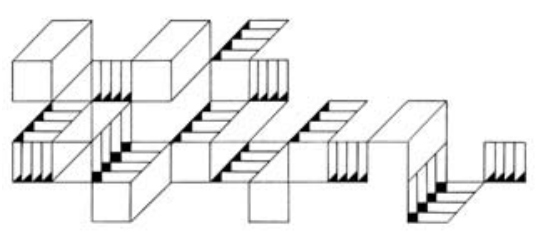

Hugo Sousa

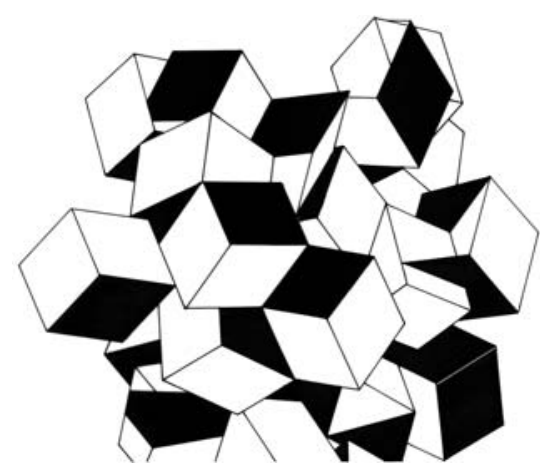

Ricardo Mendes
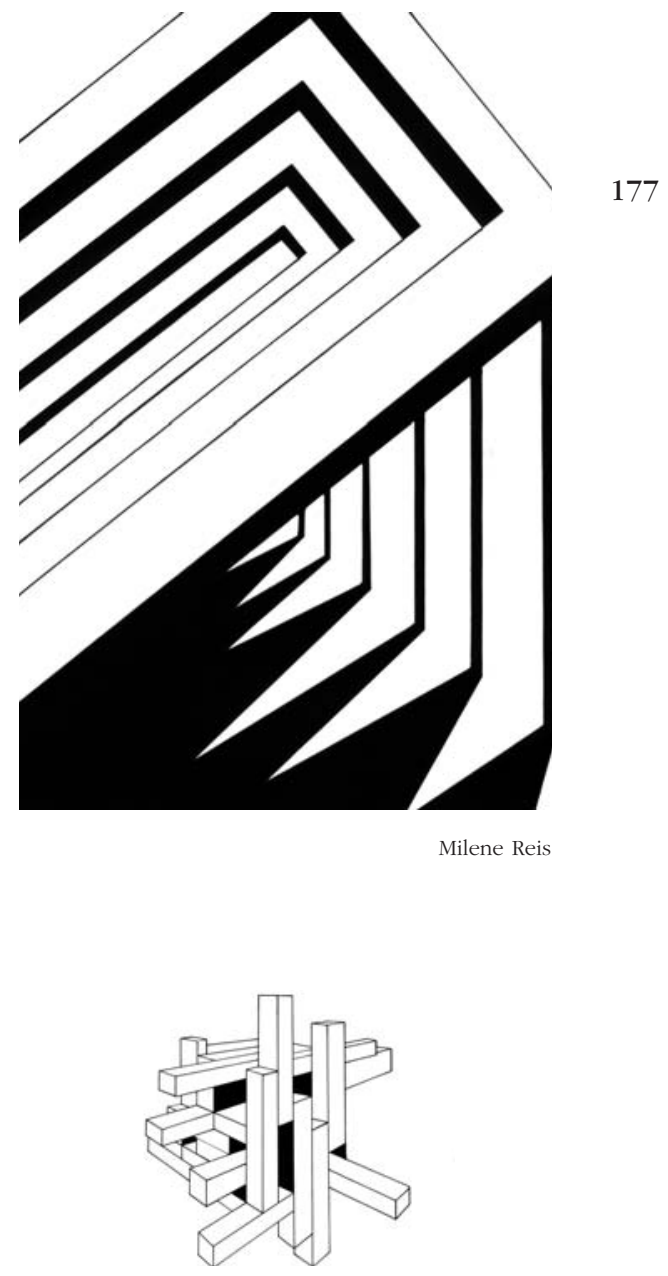

Ana Nogueira

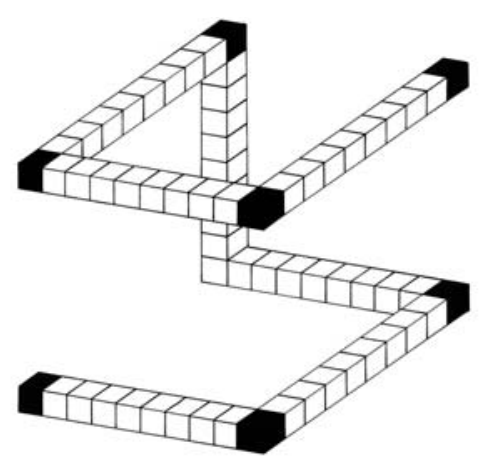

Duarte Pires 

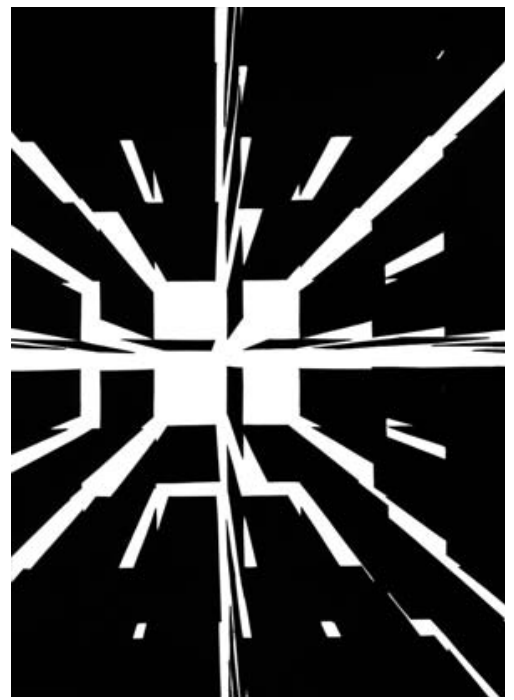

Ivo Lapa

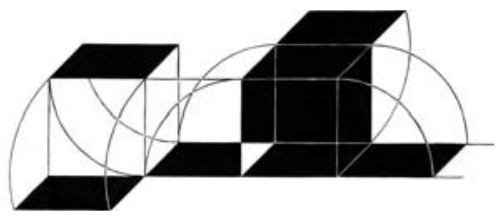

Isabel Boavida

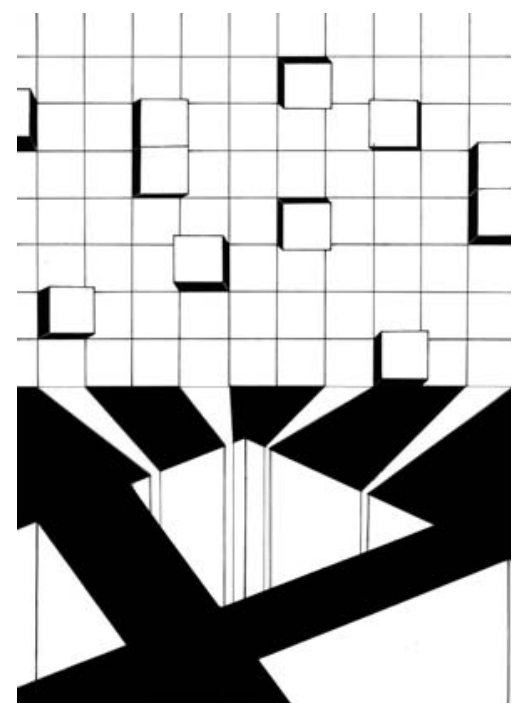

Milene Reis

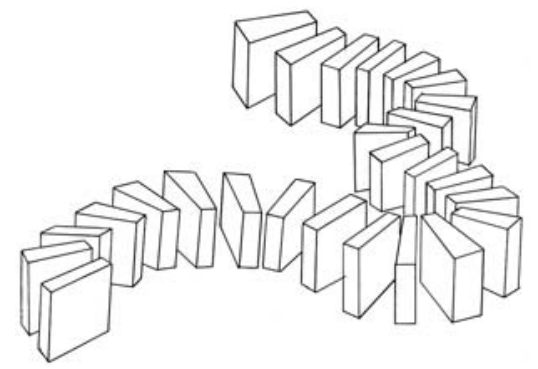

Andreia Coutinho

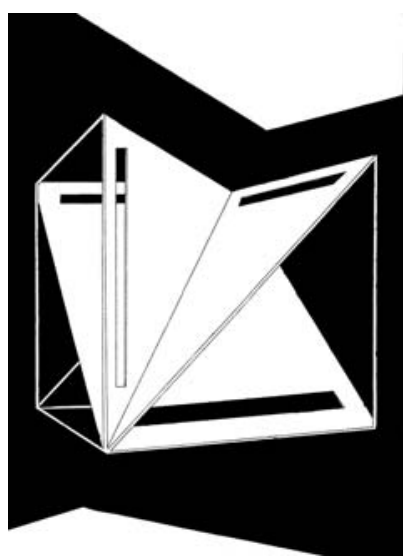

Pedro Chaves

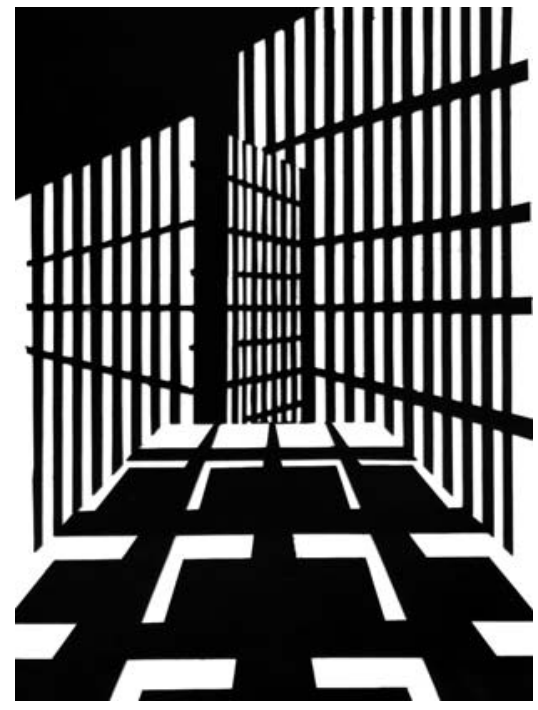

Pedro Chaves 


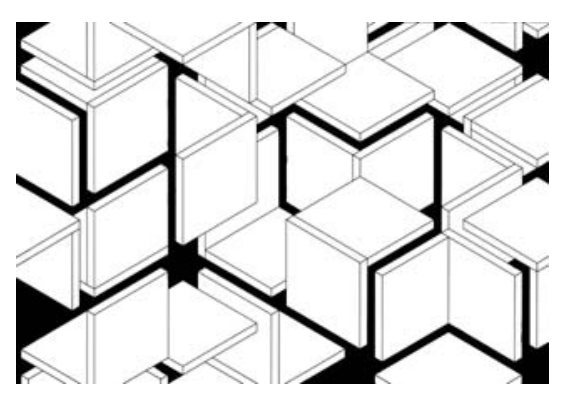

Rui Cunha

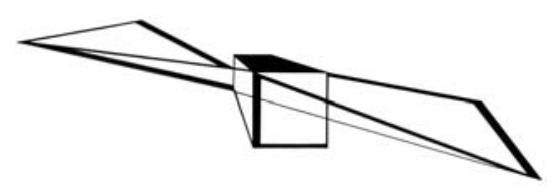

Marina Neves

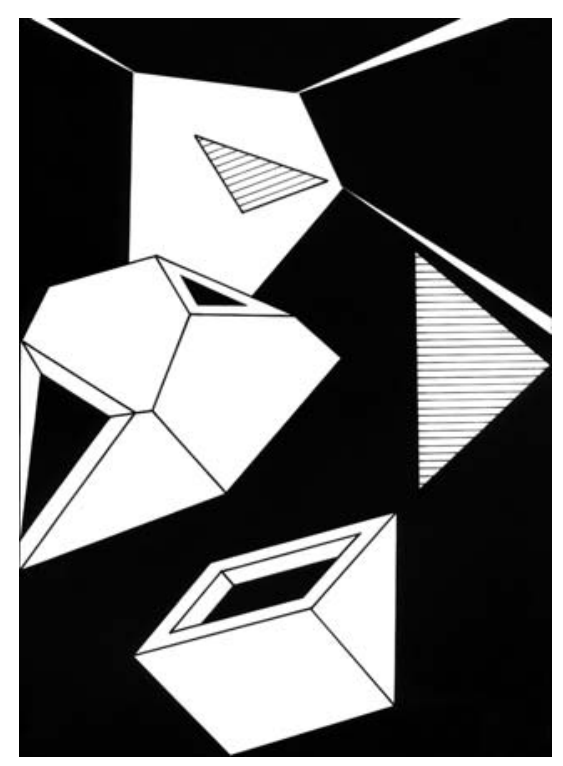

Cátia Silva

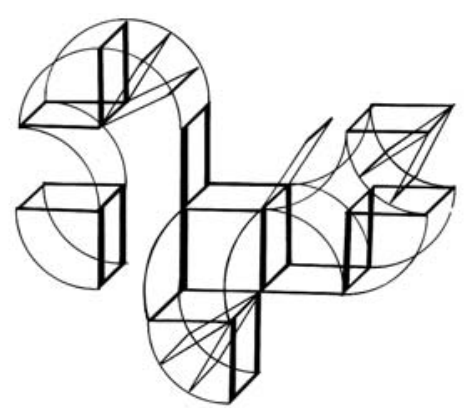

Marina Neves

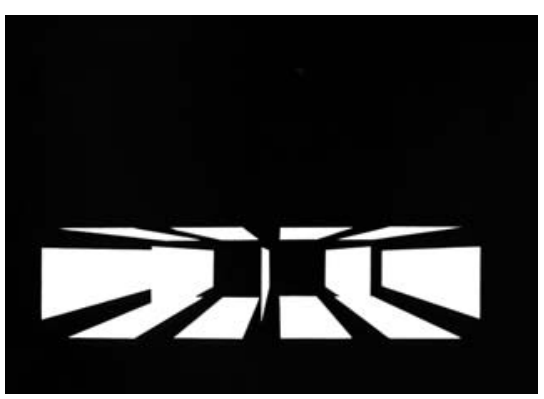

Ivo Lapa

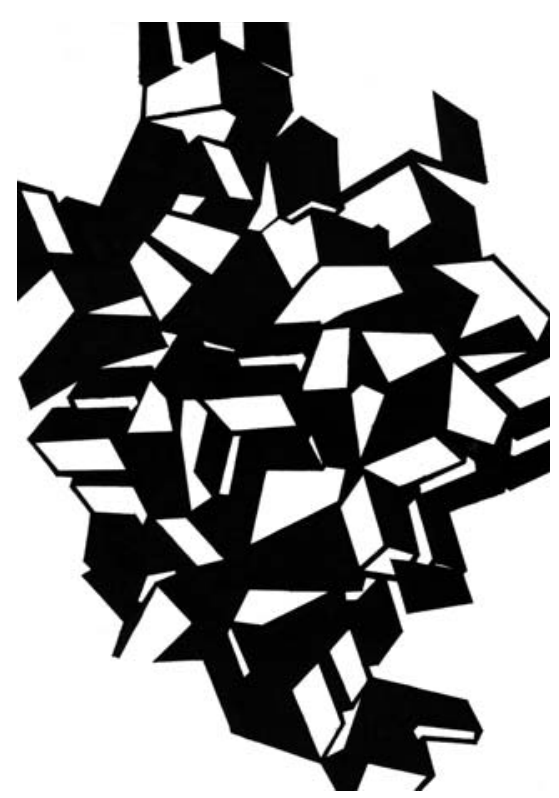

Guida Gonçalves 
(Página deixada propositadamente em branco) 
A MAQUETA COMO INSTRUMENTO DE EXPRESSÃO PLÁSTICA E CONCEPTUAL 
(Página deixada propositadamente em branco) 
Nestes exercícios foi dado aos alunos uma dimensão, $15 \times 15 \times 30 \mathrm{~cm}$, para executarem uma caixa, aberta num dos topos, maqueta para um espaço imaginário.

Não foi sugerida qualquer escala, pelo que as maquetas podem remeter para espaços de várias dimensões.

O que aqui se explora são os jogos perceptivos, na utilização de vários níveis de representação, aliando formas tridimensionais a representações bidimensionais, em artifícios de trompe l'oeil. Desfazem-se coordenadas ao simular, na manipulação das perspectivas, diferentes profundidades.

Nestes exercícios, ao contrário dos exercícios das disciplinas de Projecto, as maquetas são um fim em si. Aqui é sobretudo o carácter de imagem, no sentido de estímulo à imaginação, que é explorado nestas maquetas.

Ao mesmo tempo, utilizando o desenho, ou melhor, os desenhos como instrumento de concepção destes objectos, os alunos desenvolvem as potencialidades operativas do desenho enquanto instrumento de concepção, enquanto instrumento de projecto. 


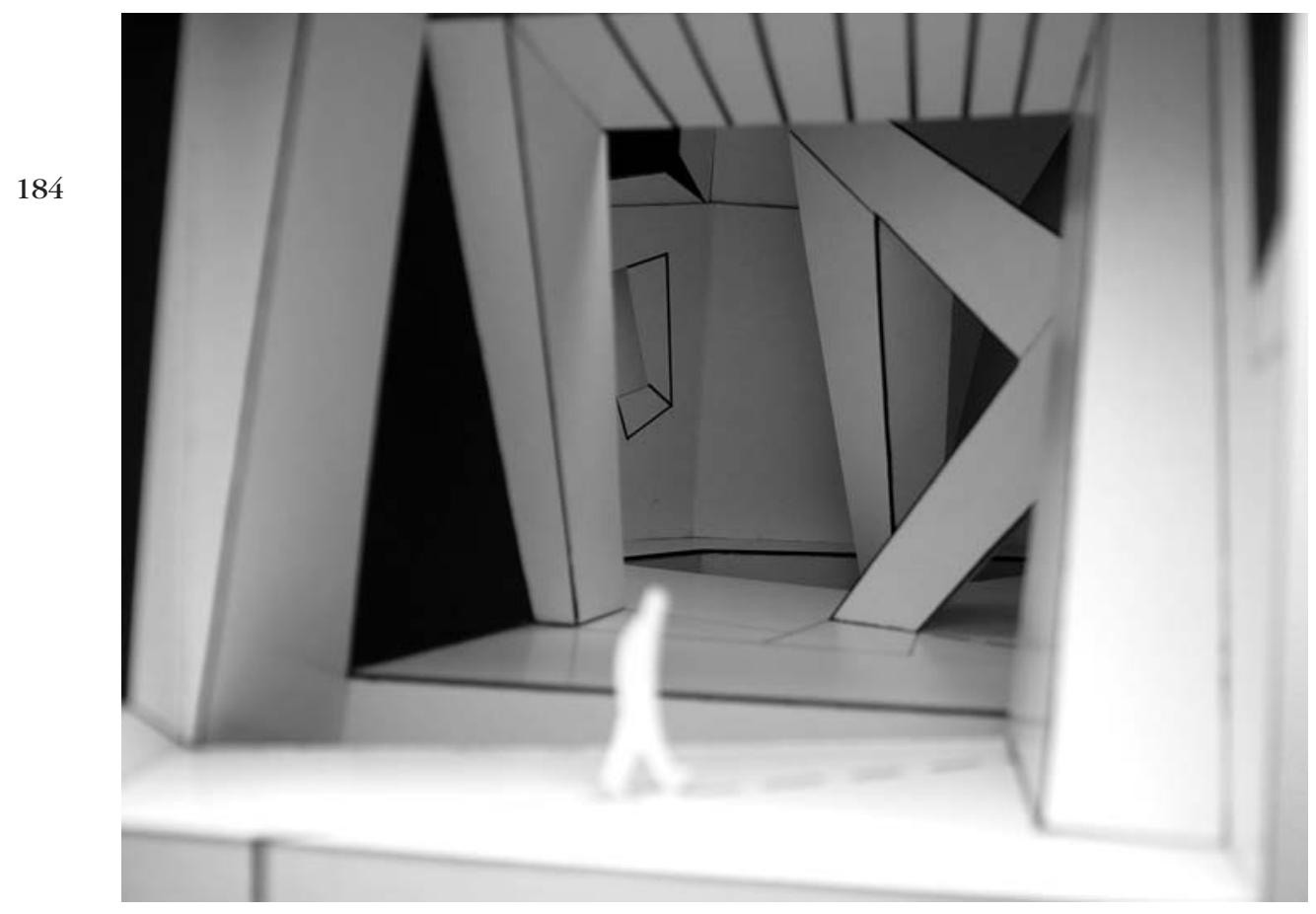

Cátia Silva 

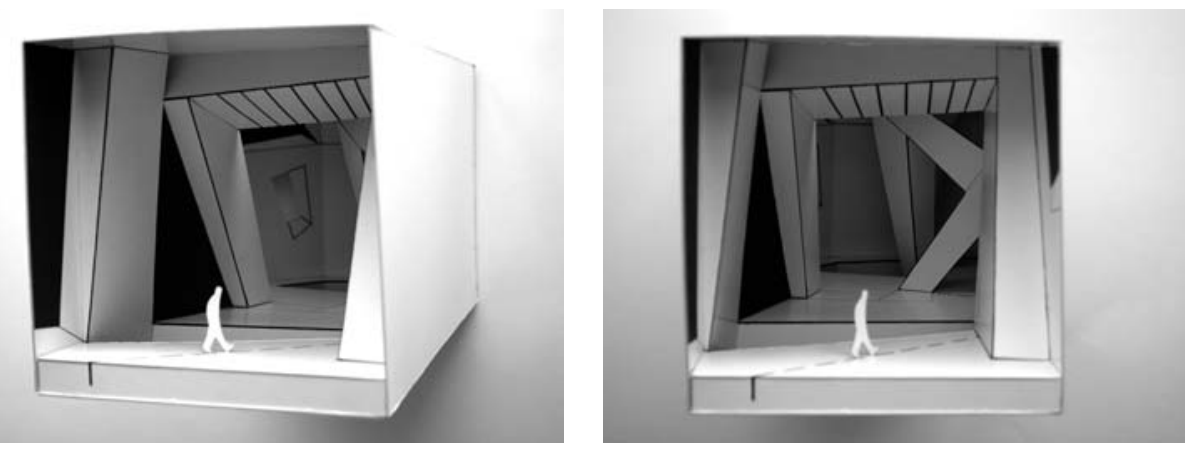

185

Cátia Silva
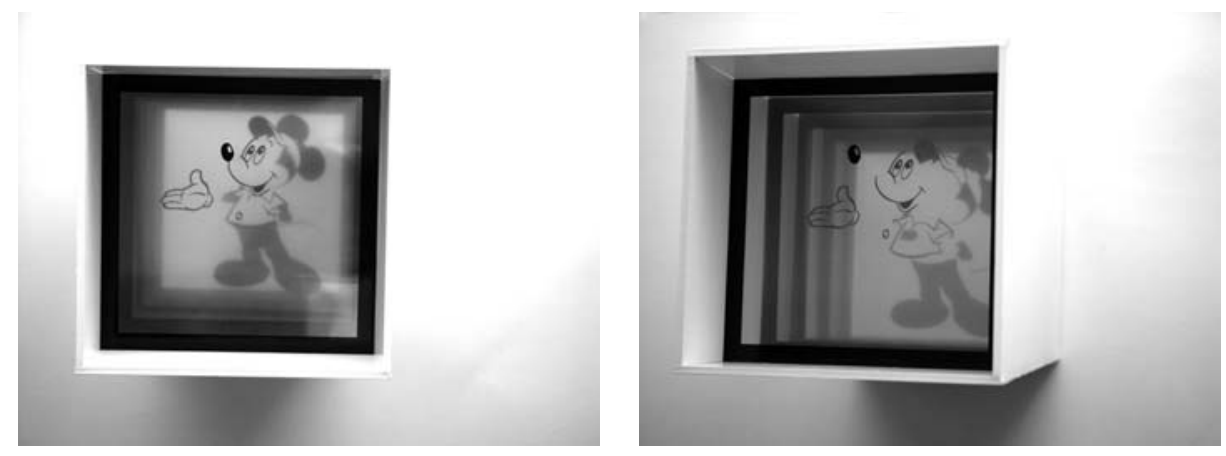

Diogo Almeida
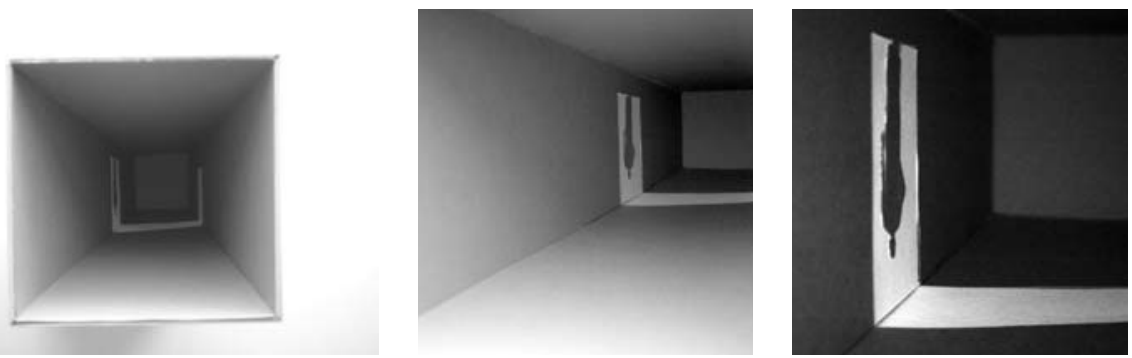

Gil Gama 

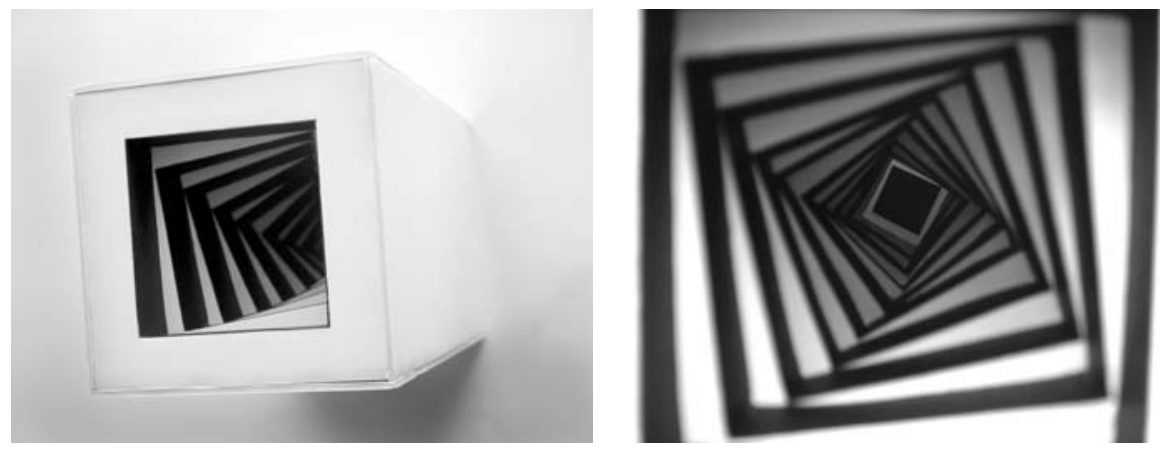

Ana Consciência
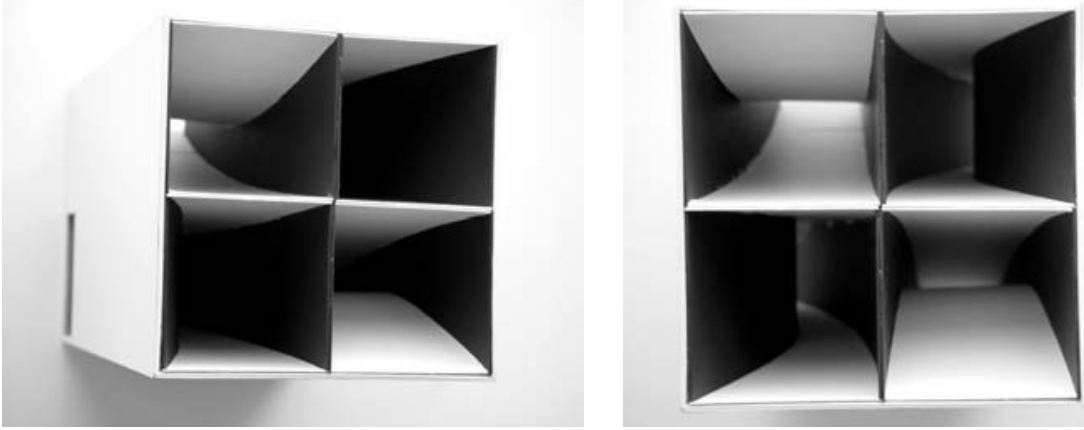

João Castanheira
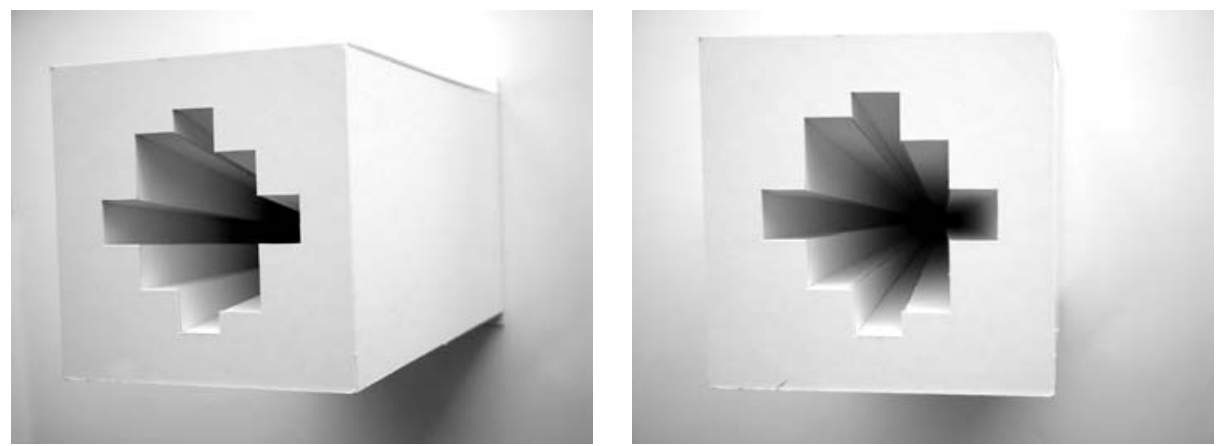

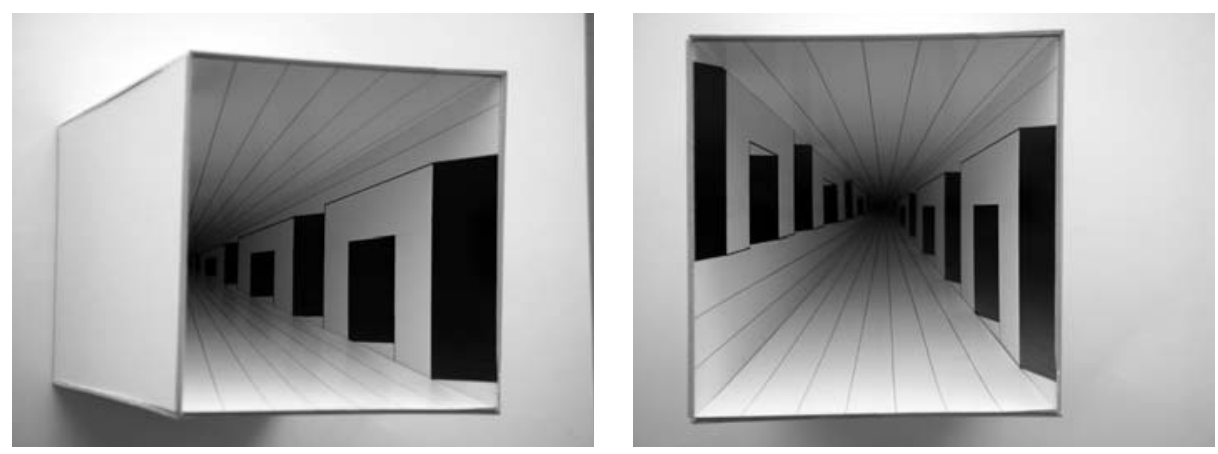

187
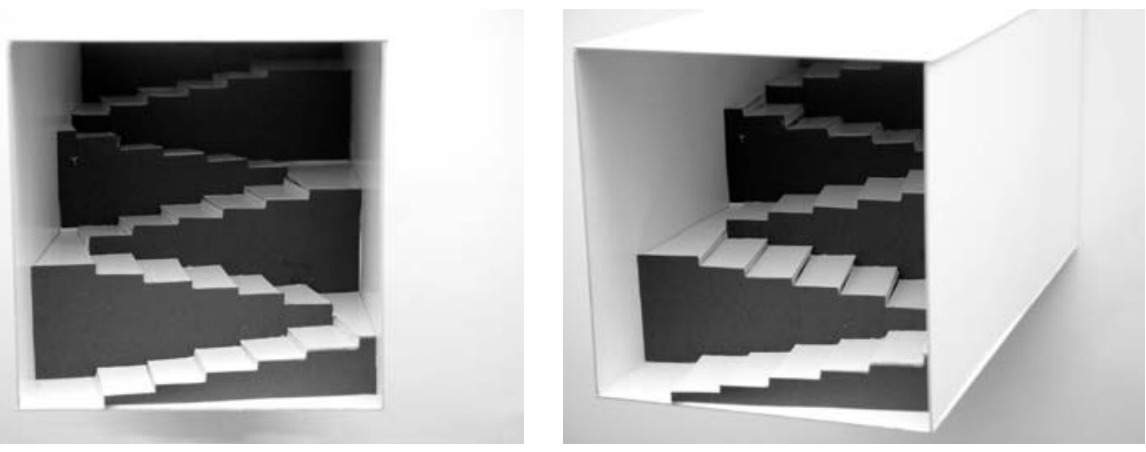

Marina Neves
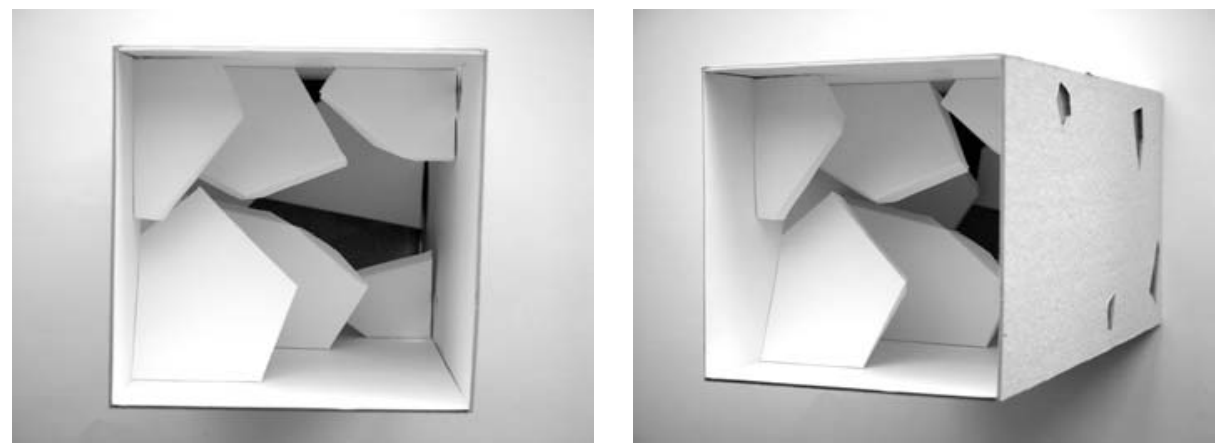

Andreia Coutinho 

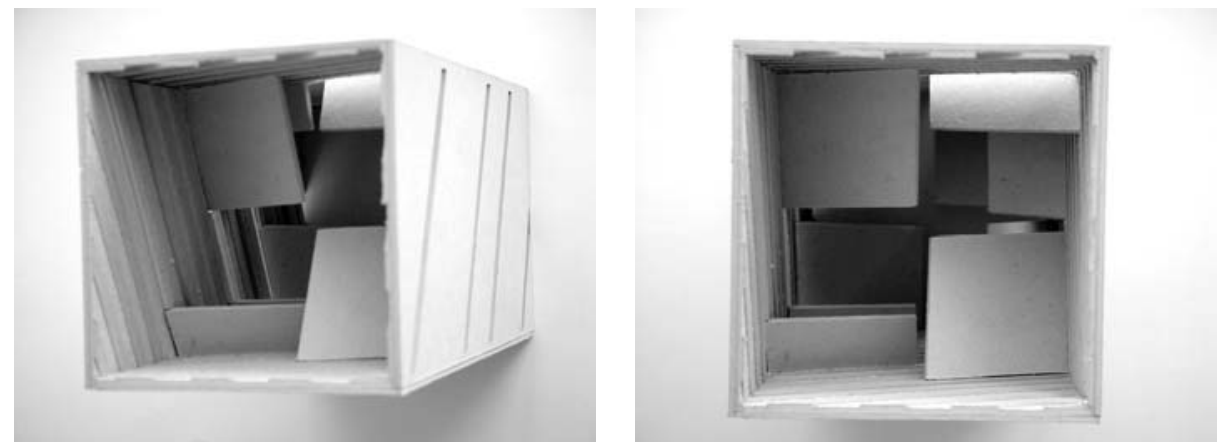

Filipa Carvalho
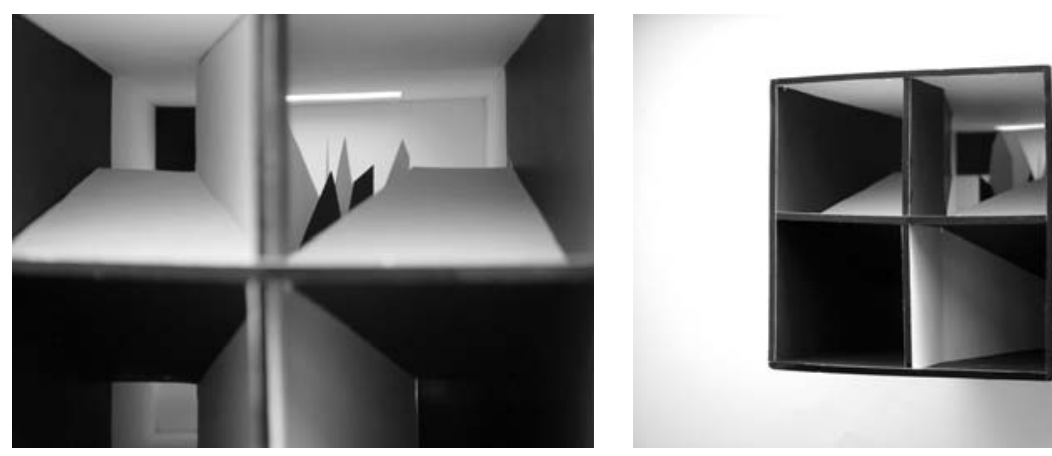

Jeremias Nascimento
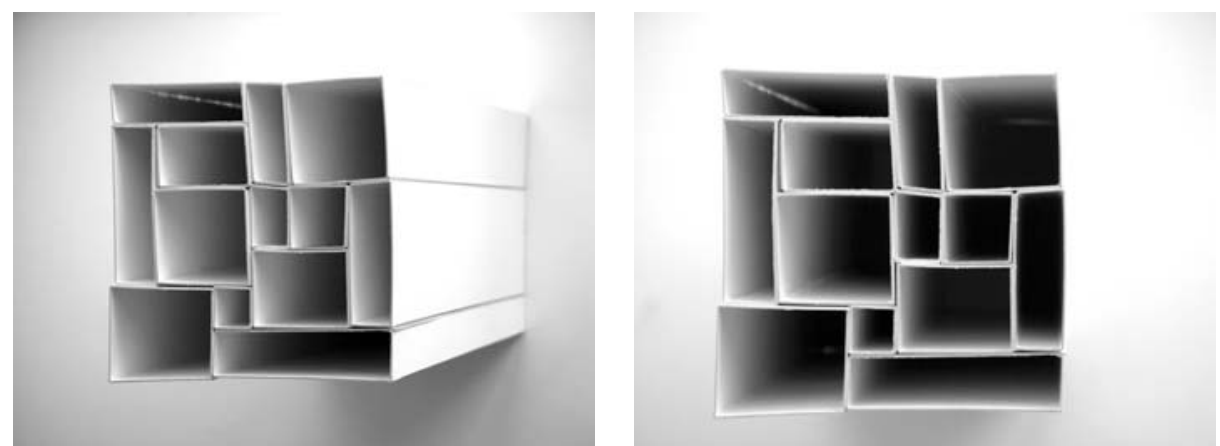

Mafalda Mourão 

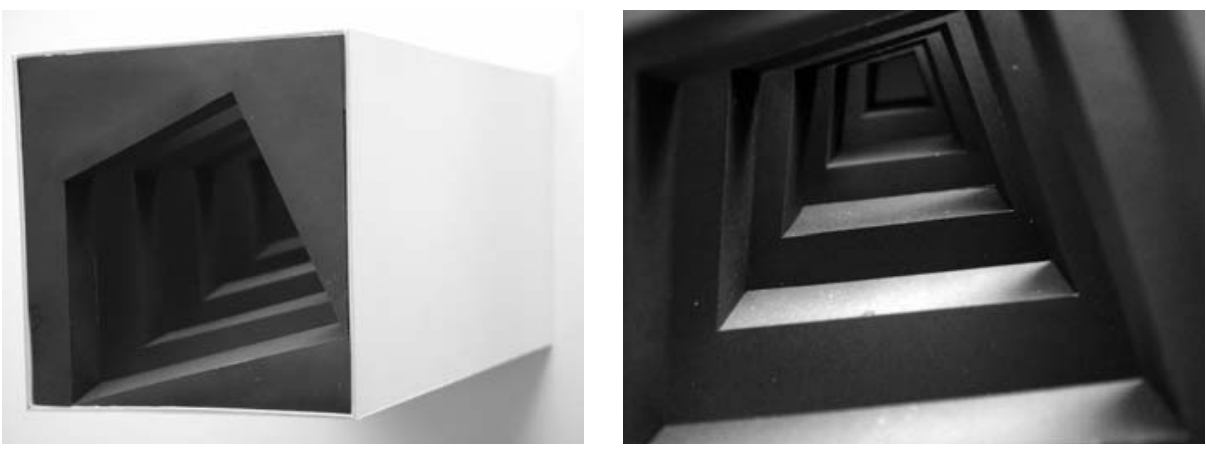

Isabel Boavida
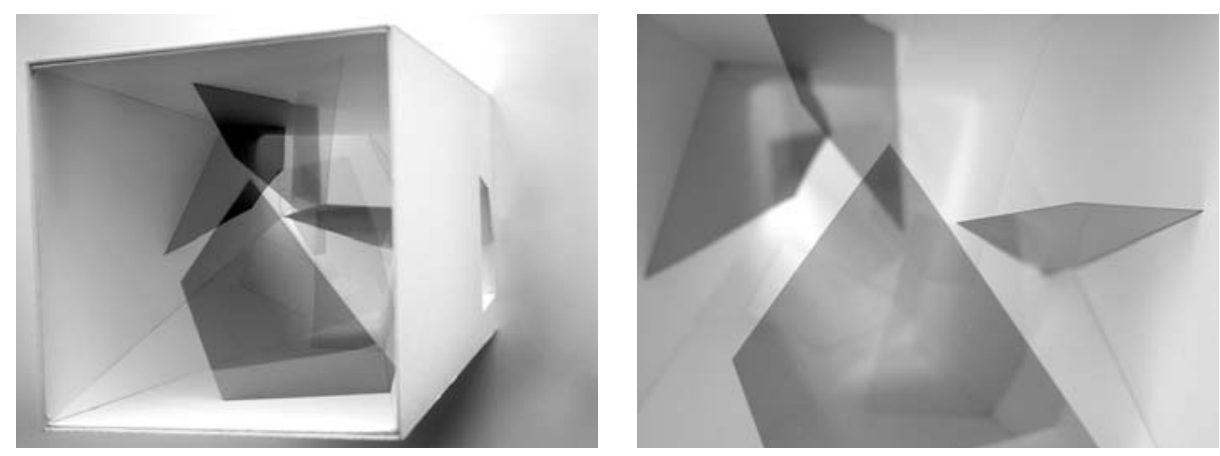

Rui Cunha
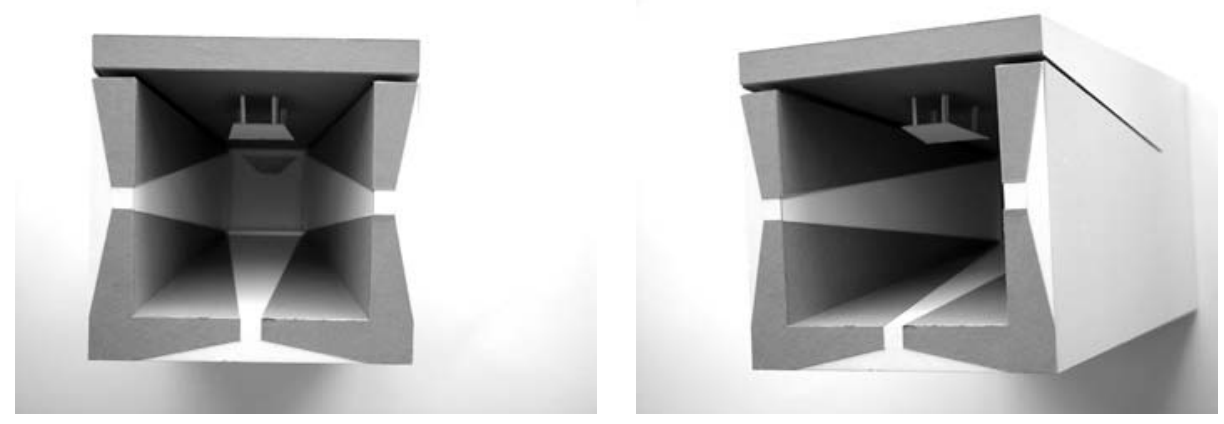

Ricardo Mendes 

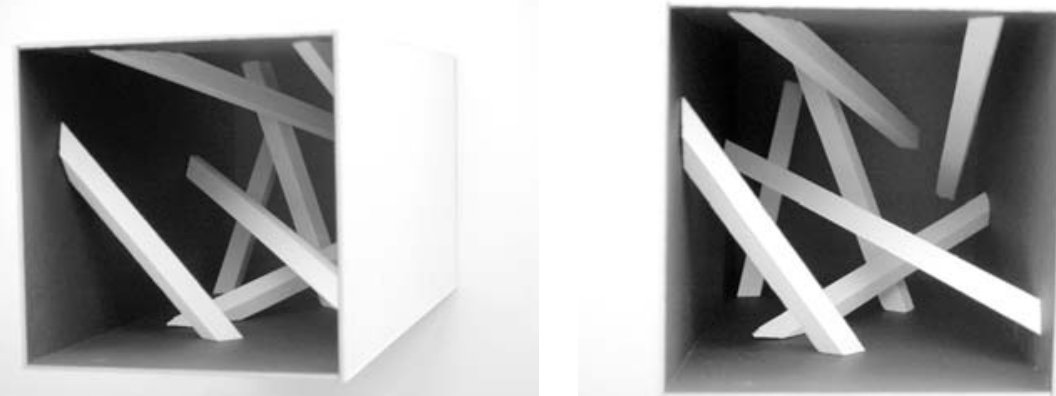

Filipa Alfaro
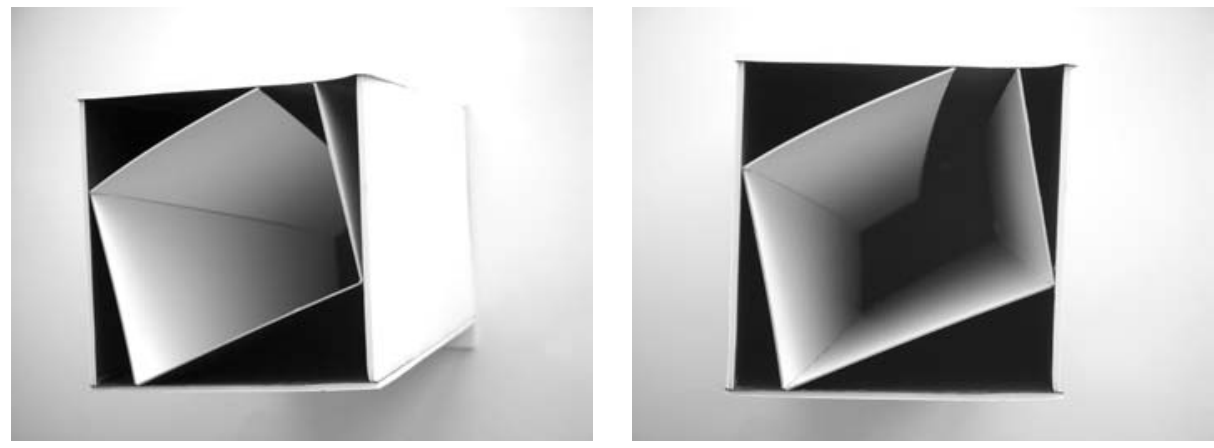

Nuno Gaspar
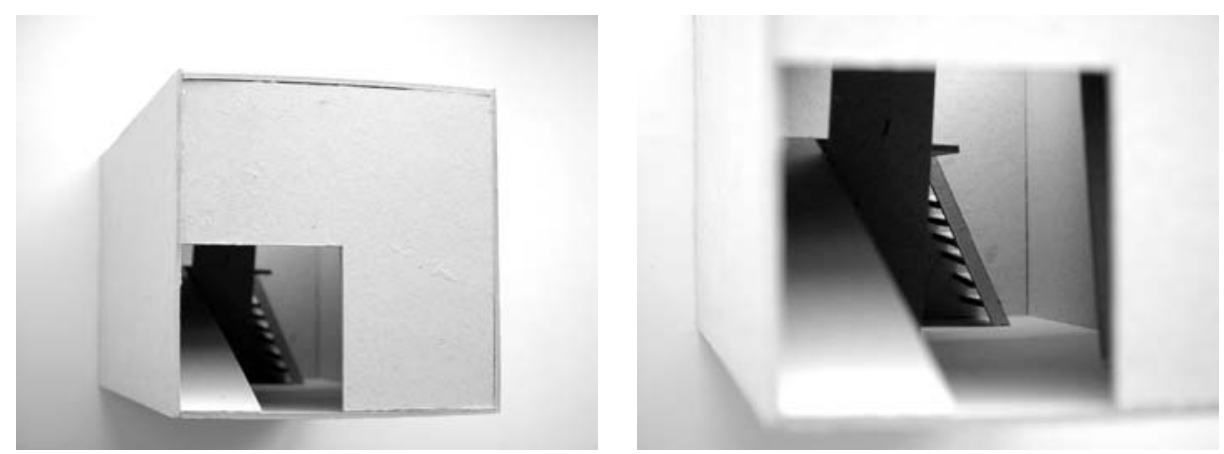

Manuel Machado 

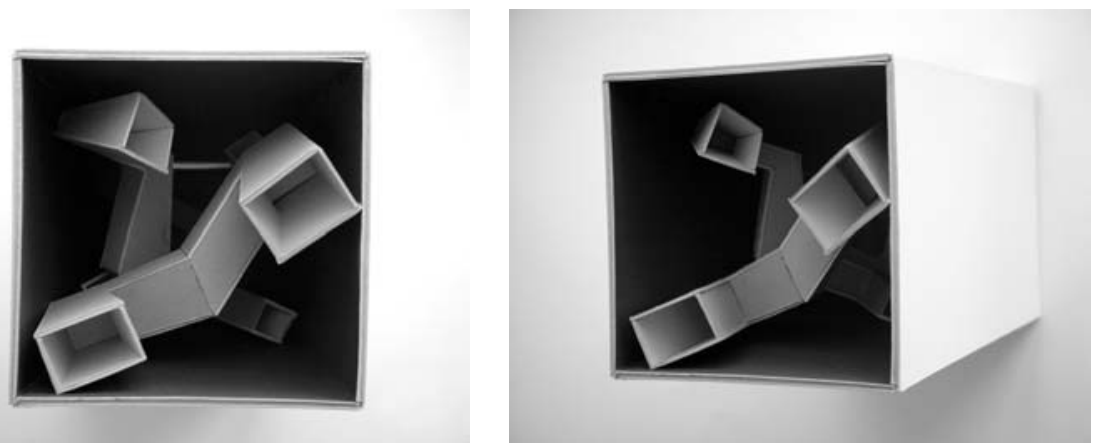

191
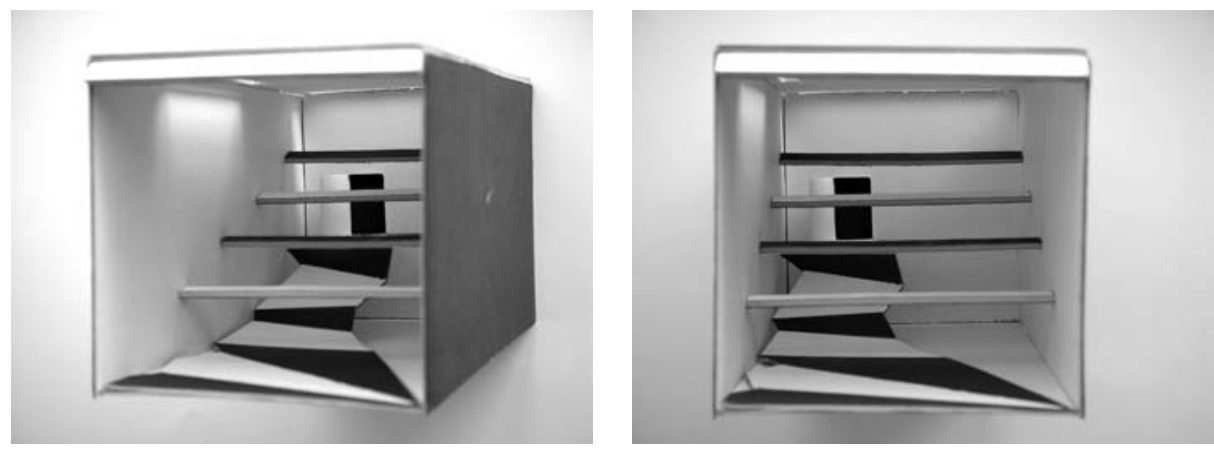

Paulo Lima
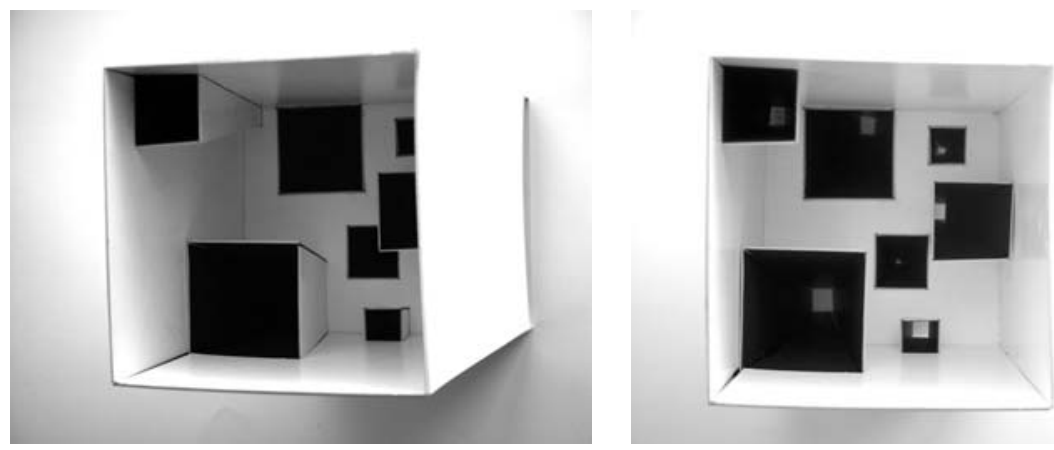

Teresa Espírito-Santo 

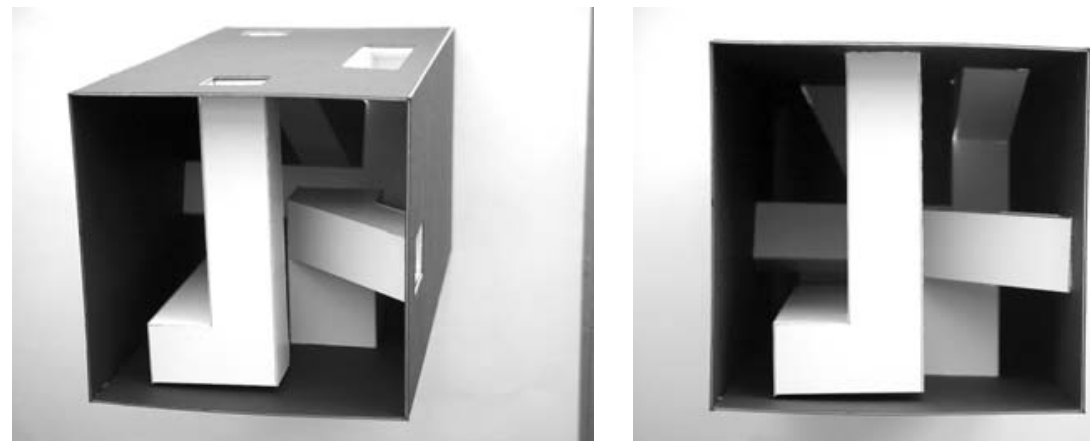

Guida Gonçalves
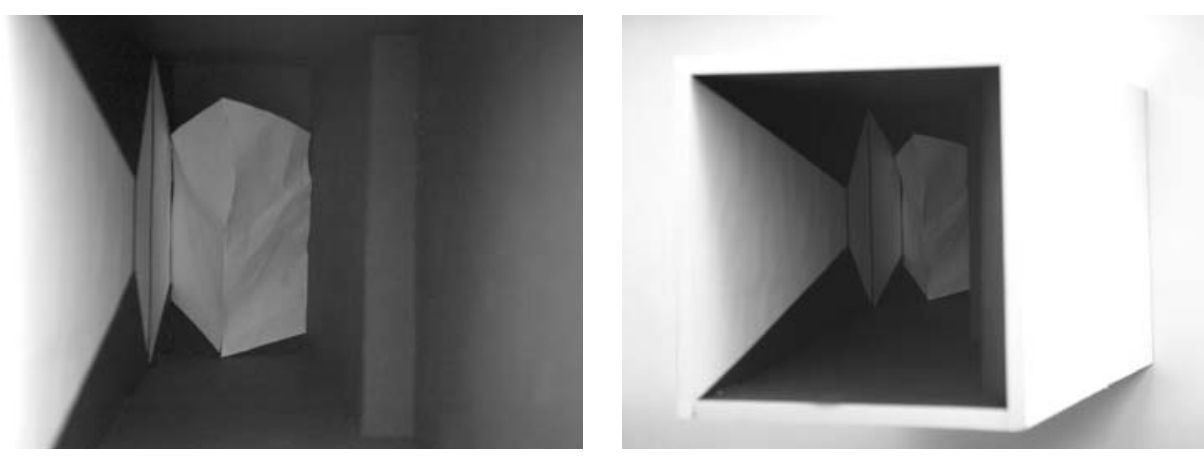

João Crisóstomo
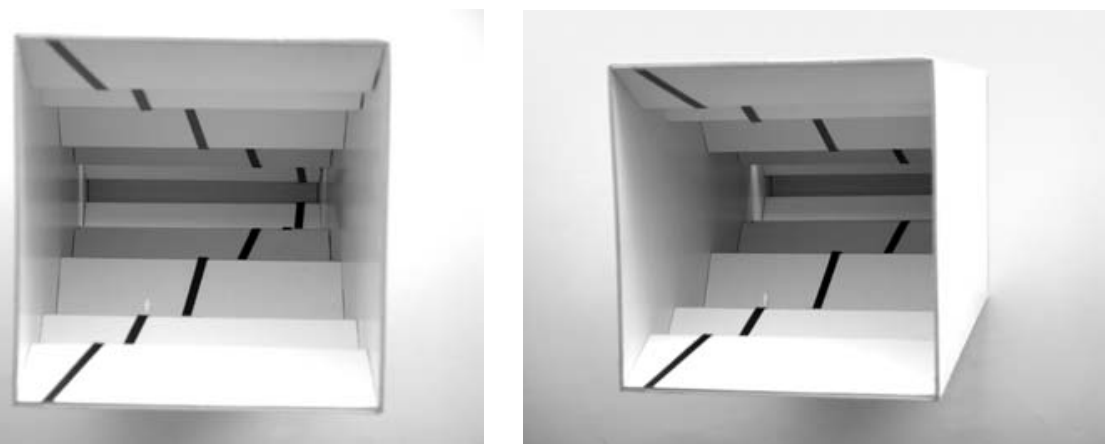

Daniel Pires 

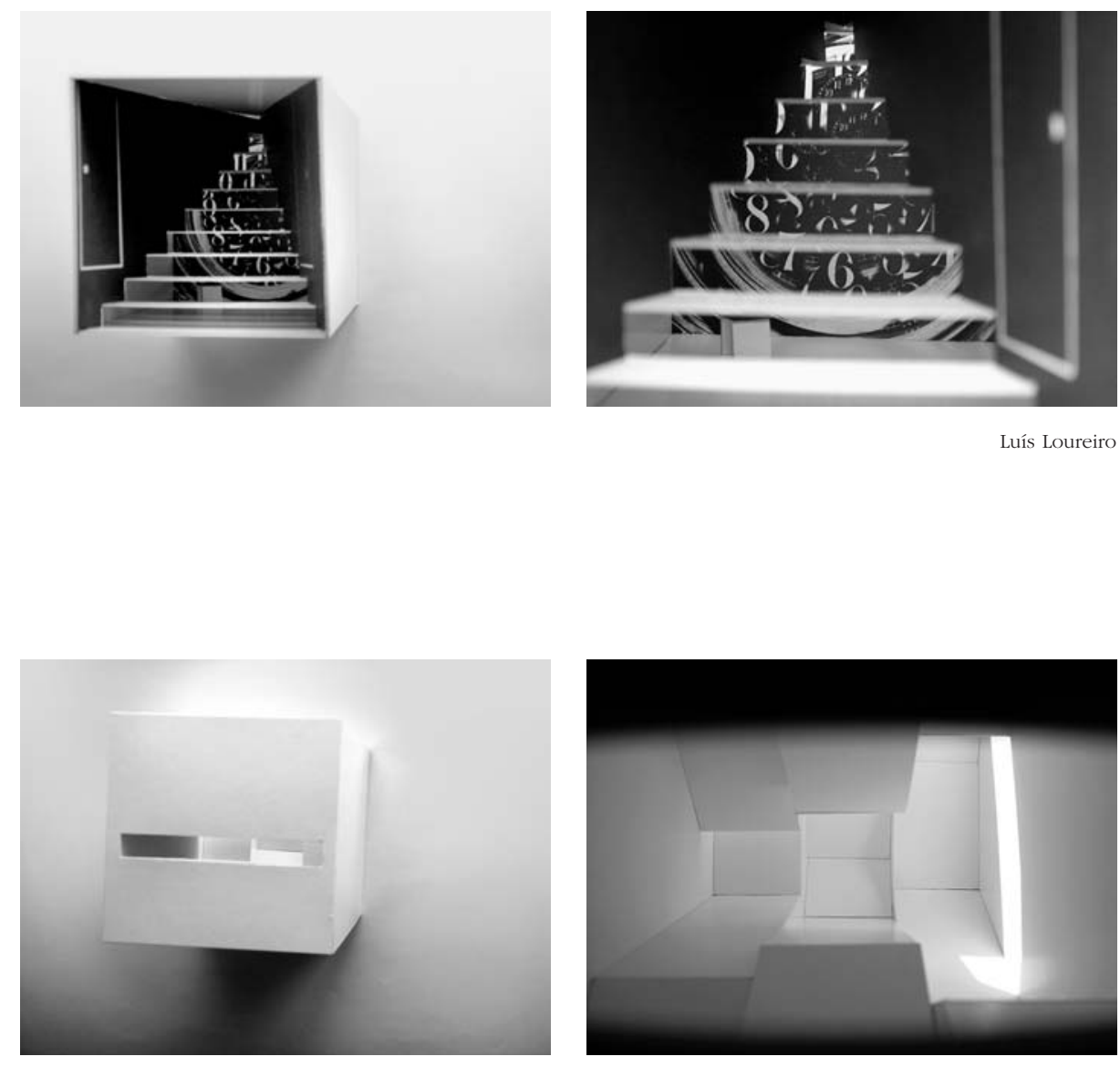

Luísa Correia
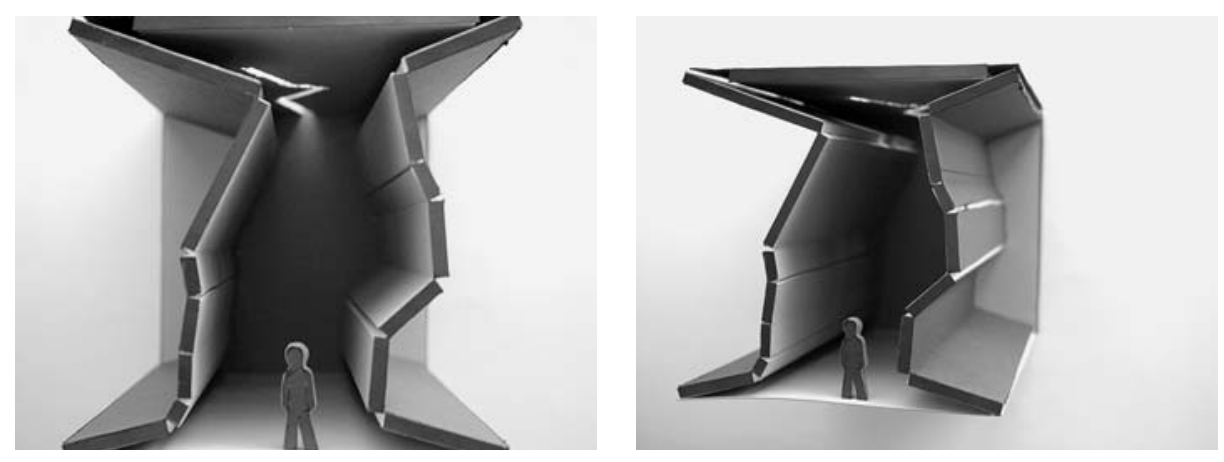

Raquel Margarido 
Respondendo ao repto da Semana Cultural da Universidade de Coimbra em 2006, que tinha o mar como temática, a disciplina de Desenho II propôs exercícios que resultaram na exposição/instalação $100 \mathrm{~cm}^{2}$ de mar.

Utilizando imagens cuja estrutura partiu da subdivisão do quadrado, alia-se aqui a racionalidade geométrica à poética conceptual. Variações da imagem gráfica de mar à semelhança de possibilidades de logótipos, de dimensão constante de $100 \mathrm{~cm}^{2}$, estão contidas em territórios de quatro lados, pequenos mundos quadrados, paisagens condicionados pela racionalidade da estrutura de um quadrado, ao mesmo tempo que potenciam a sua transformação, explodindo em múltiplas associações.

No jogo entre dimensão e escala está a exploração da possibilidade de encarar o mar como algo que está contido e não como imenso contentor. Interiorização subjectiva da ideia de mar num território. Da condição original de mar, da imensidão do que é redundantemente vasto, um mar é um mar de mar, à transformação para a condição de pequeno lago interior.

A exploração da bidimensionalidade das imagens criadas reforça o sentido abstractizante da exposição pois, na abstracção, a ausência é frequentemente estratégia de omnipresença.

Como contraponto à bidimensionalidade sublinhada destas imagens, são criadas maquetas de pequenas ilhas, de escala reduzidíssima, cujas formas denunciam a sua condição de puro artifício.. Aqui a poética específica da condição de maquete na relação entre dimensão e escala, encontra na ideia de ilha uma temática particularmente estimulante. Estas ilhas são natureza que é arquitectura. Sendo ilhas, são singulares, indivíduos, e, ao mesmo tempo, todo o território.

Com estes exercícios, o Desenho afirma a sua condição de reflexão sobre a arquitectura enquanto poética, explorando a sua plasticidade na manifestação de uma relação estética com as coisas. 


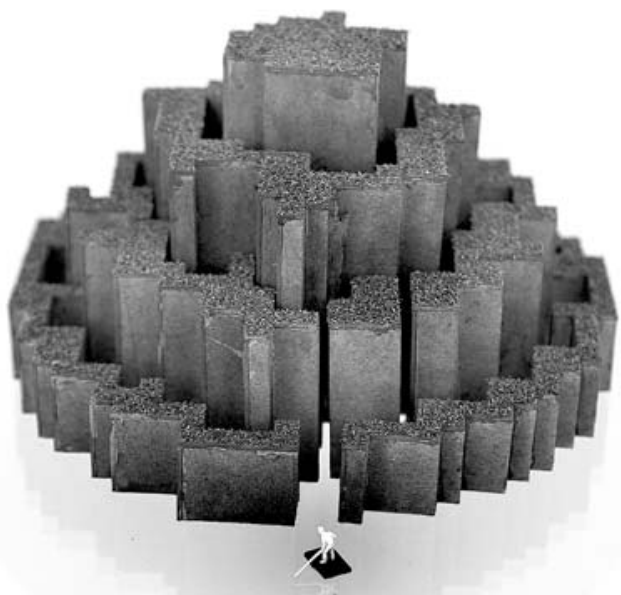

daniela parreira 

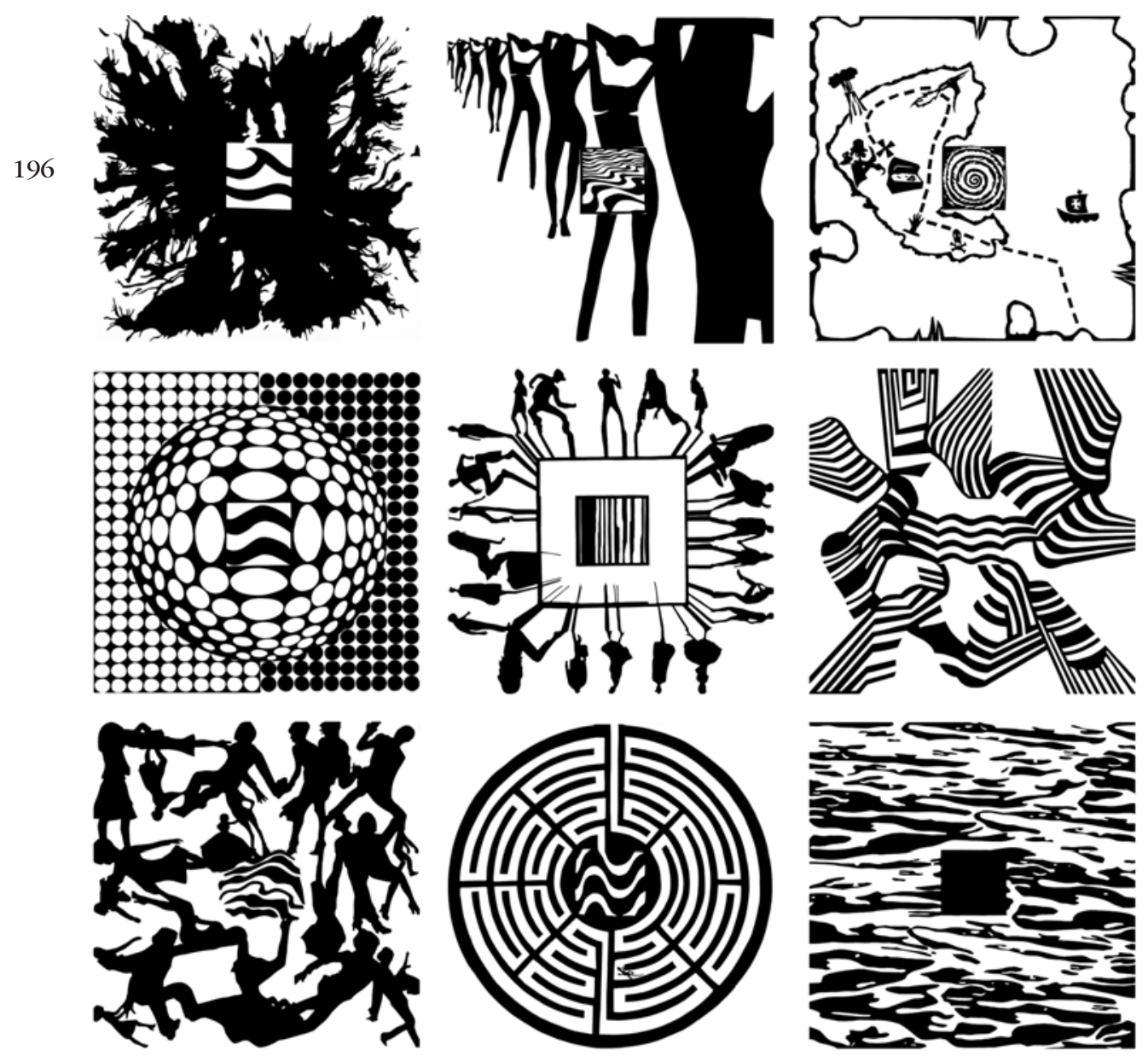

ana vieira inês oliveira pedro resende ana vieira inês lourenço inês pires maria manuel barreiros ana brett inês lourenço
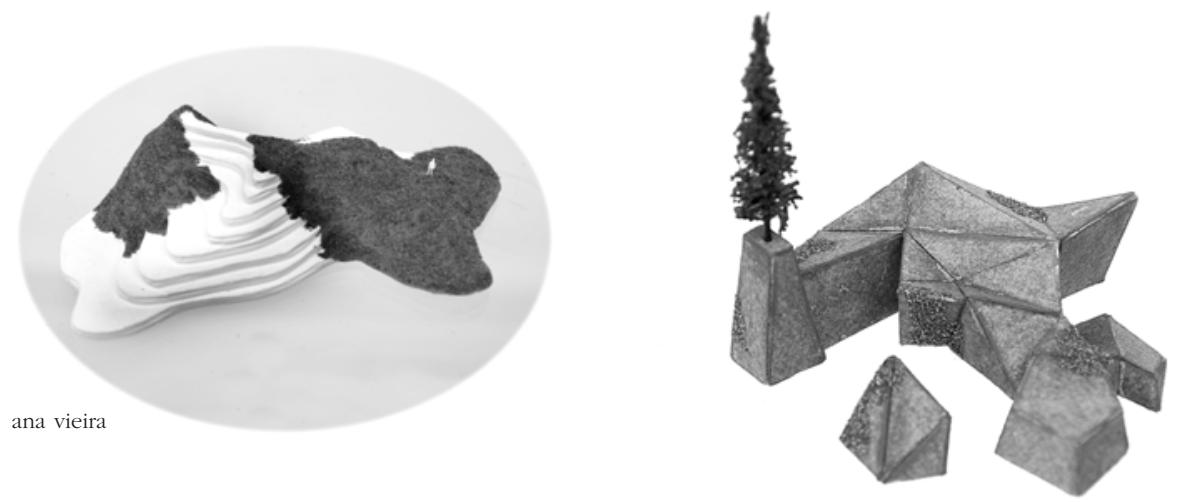

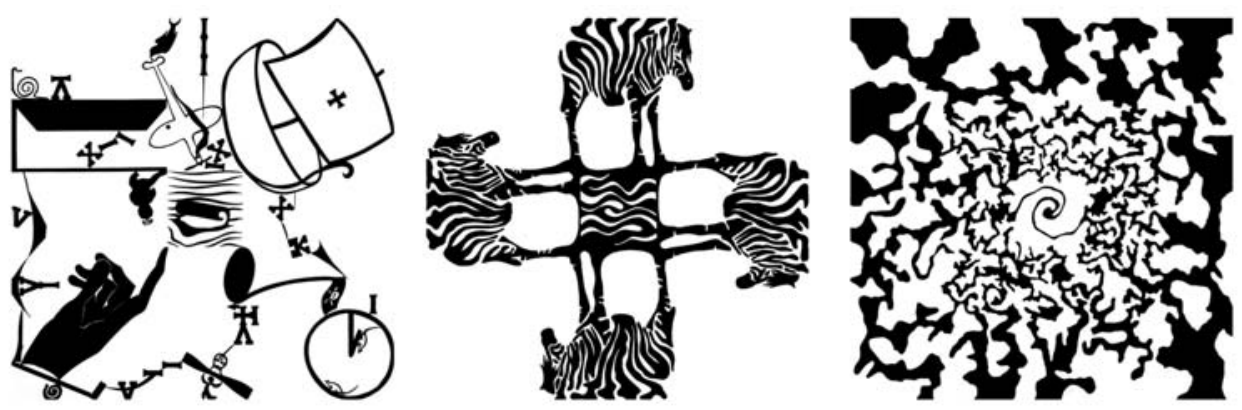

197
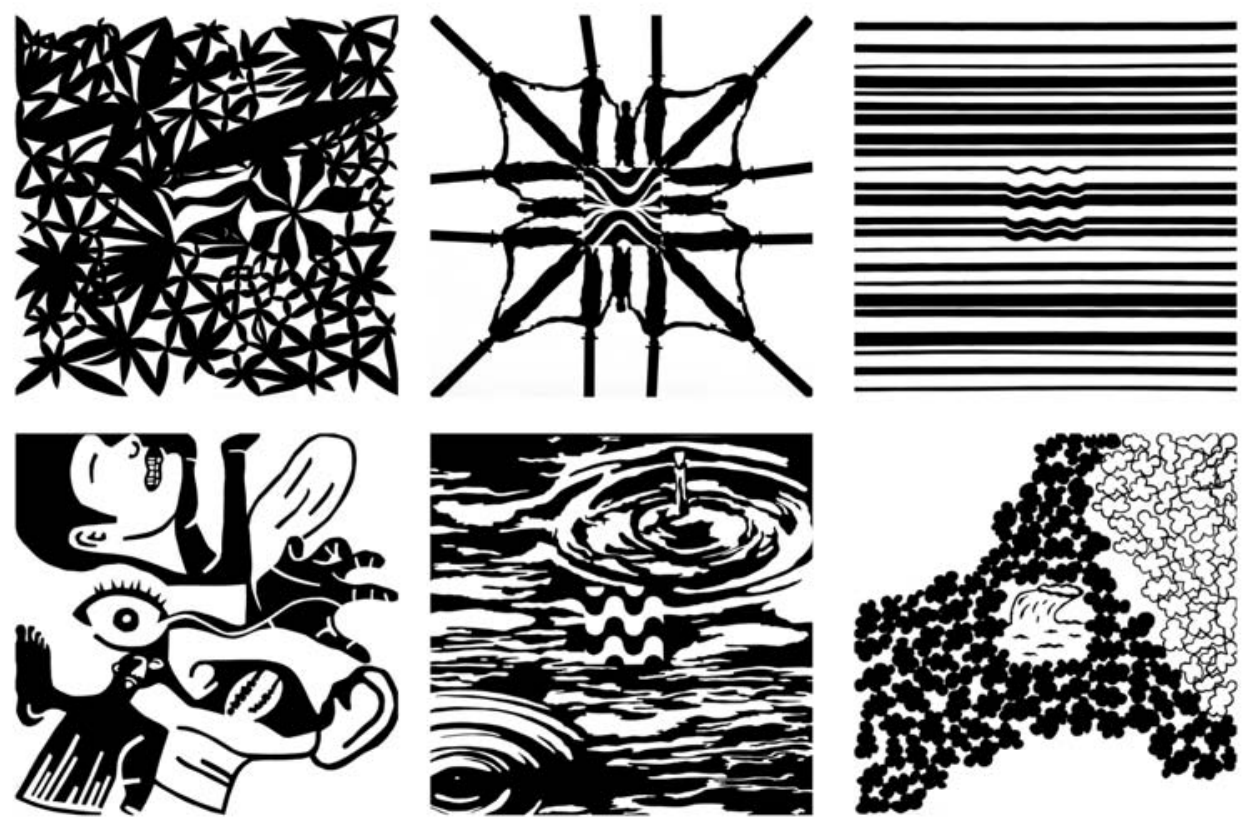

daniel oliveira sofia oliveira rui figueiredo ana margarida amaral daniela parreira ana consciência rui baltazar joão pires ana reis

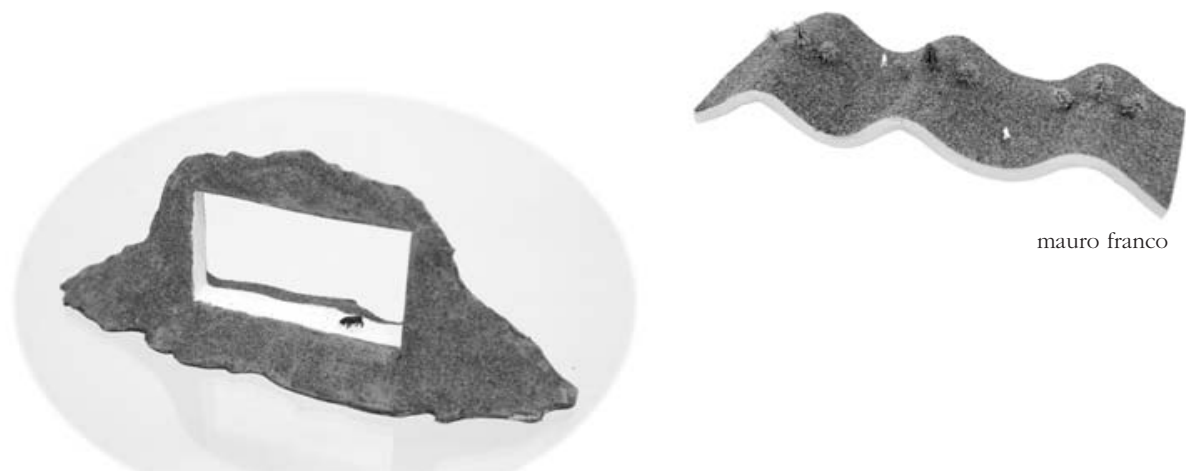



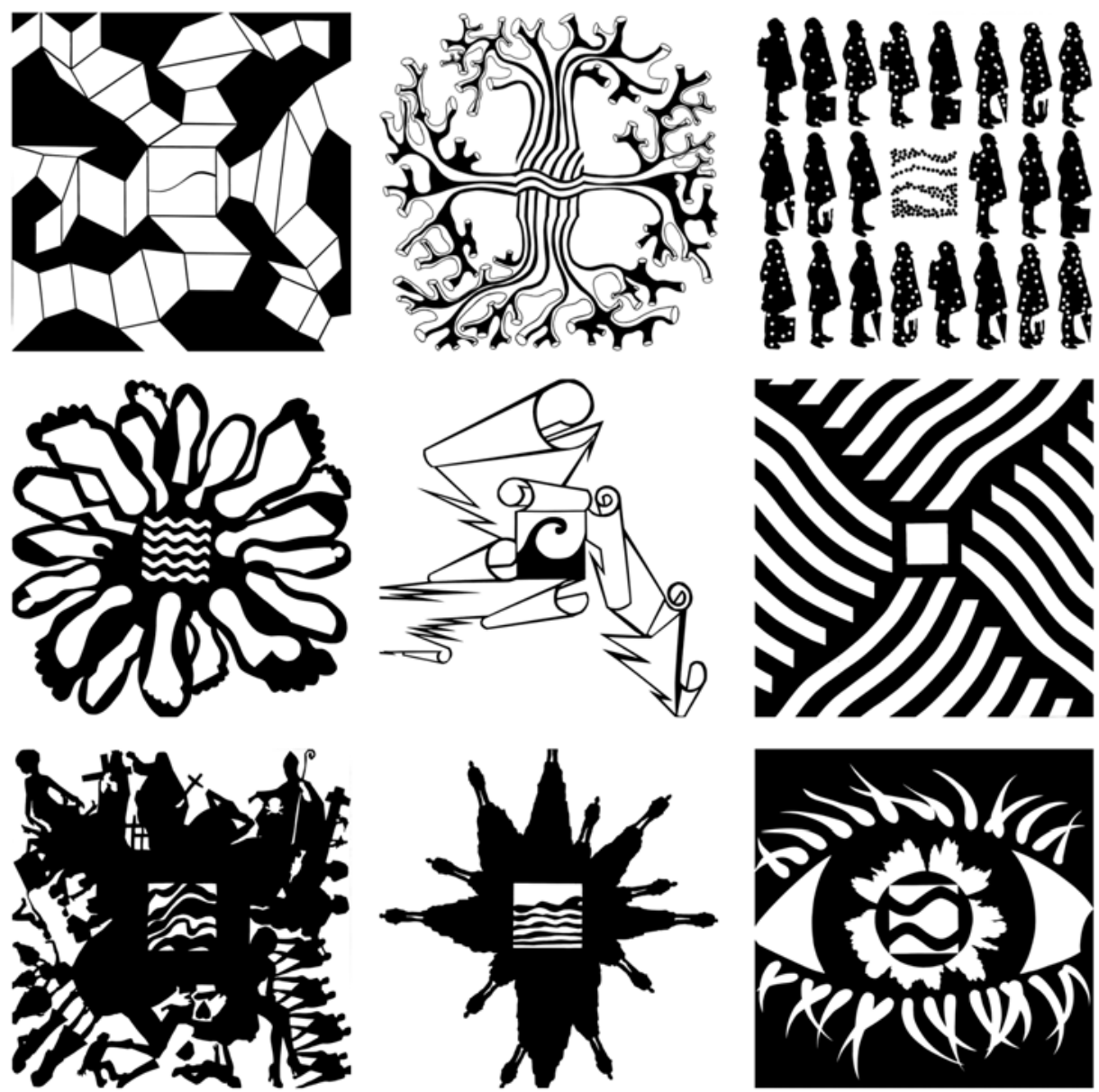

mário manaia inês moreira maria duarte sílvia silva vera rito mariana carvalho maria manuel barreiros emmanuella quinta ana vieira
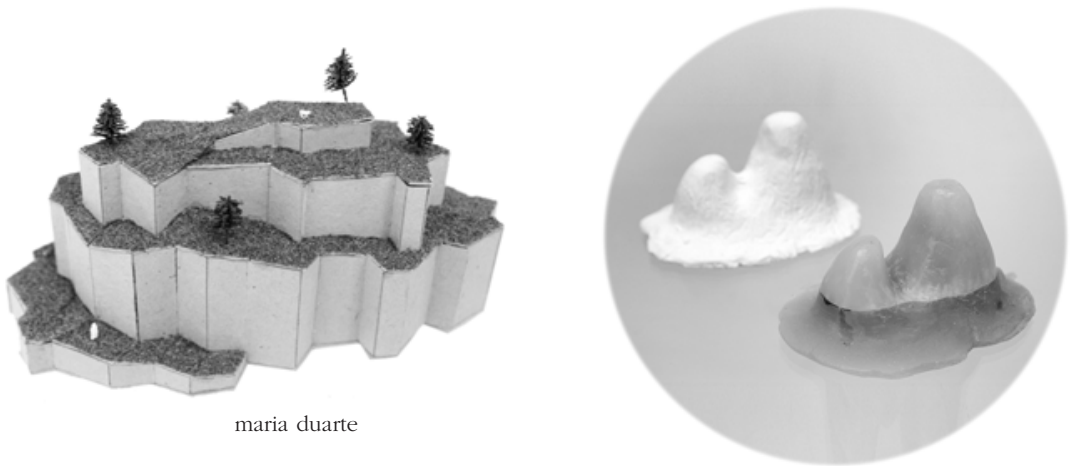

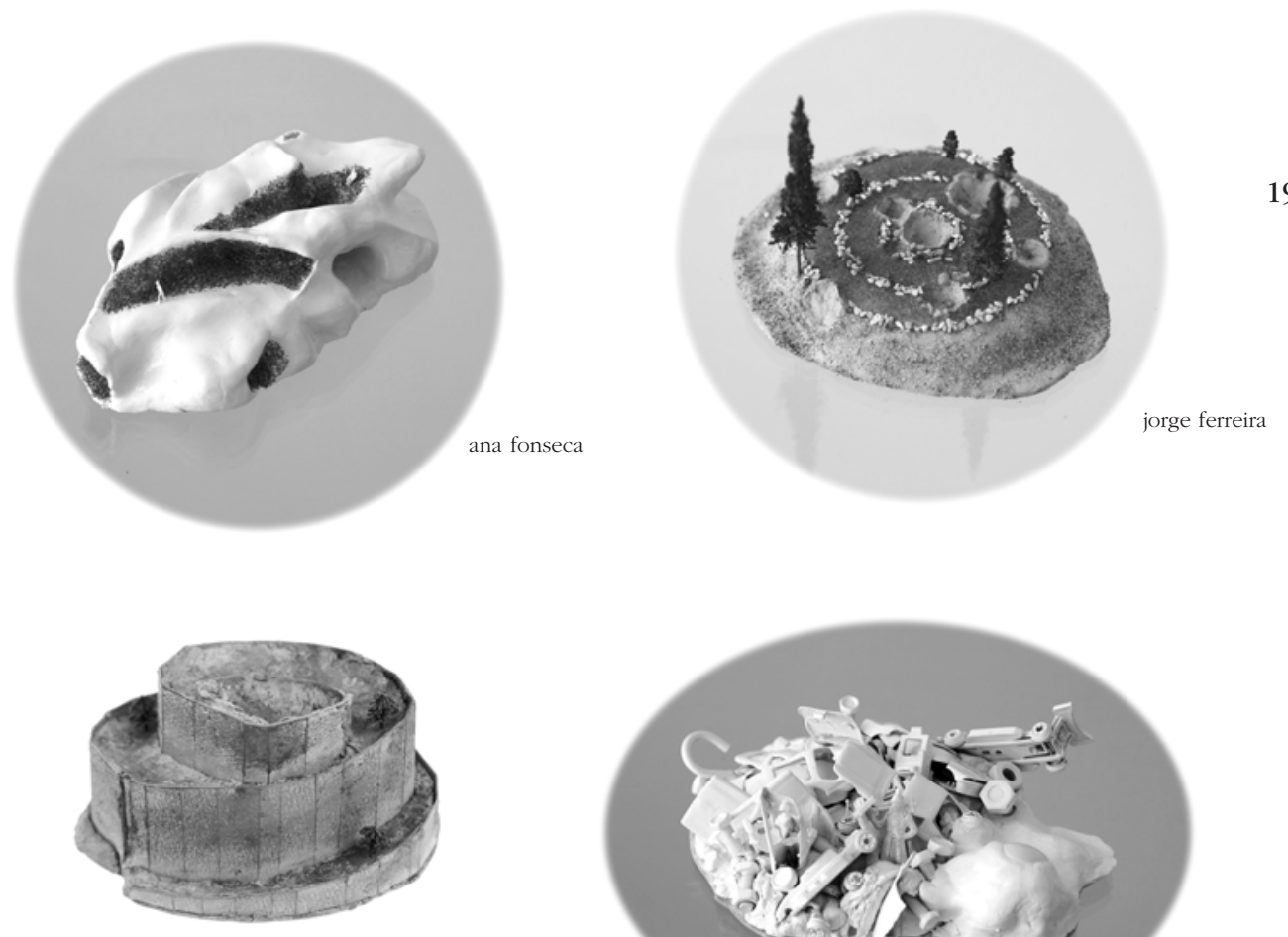

maria duarte
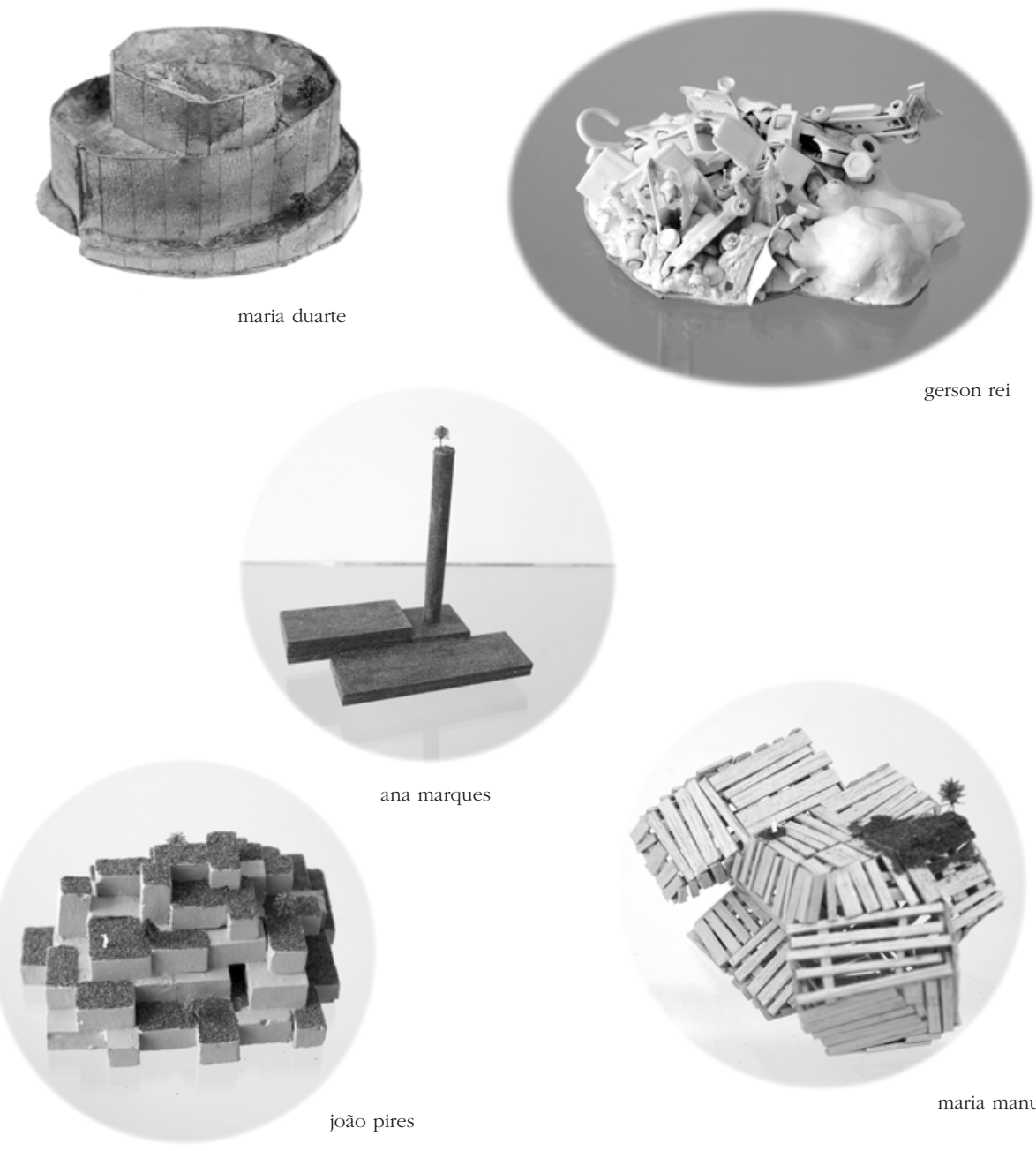

maria manuel barreiros 
200
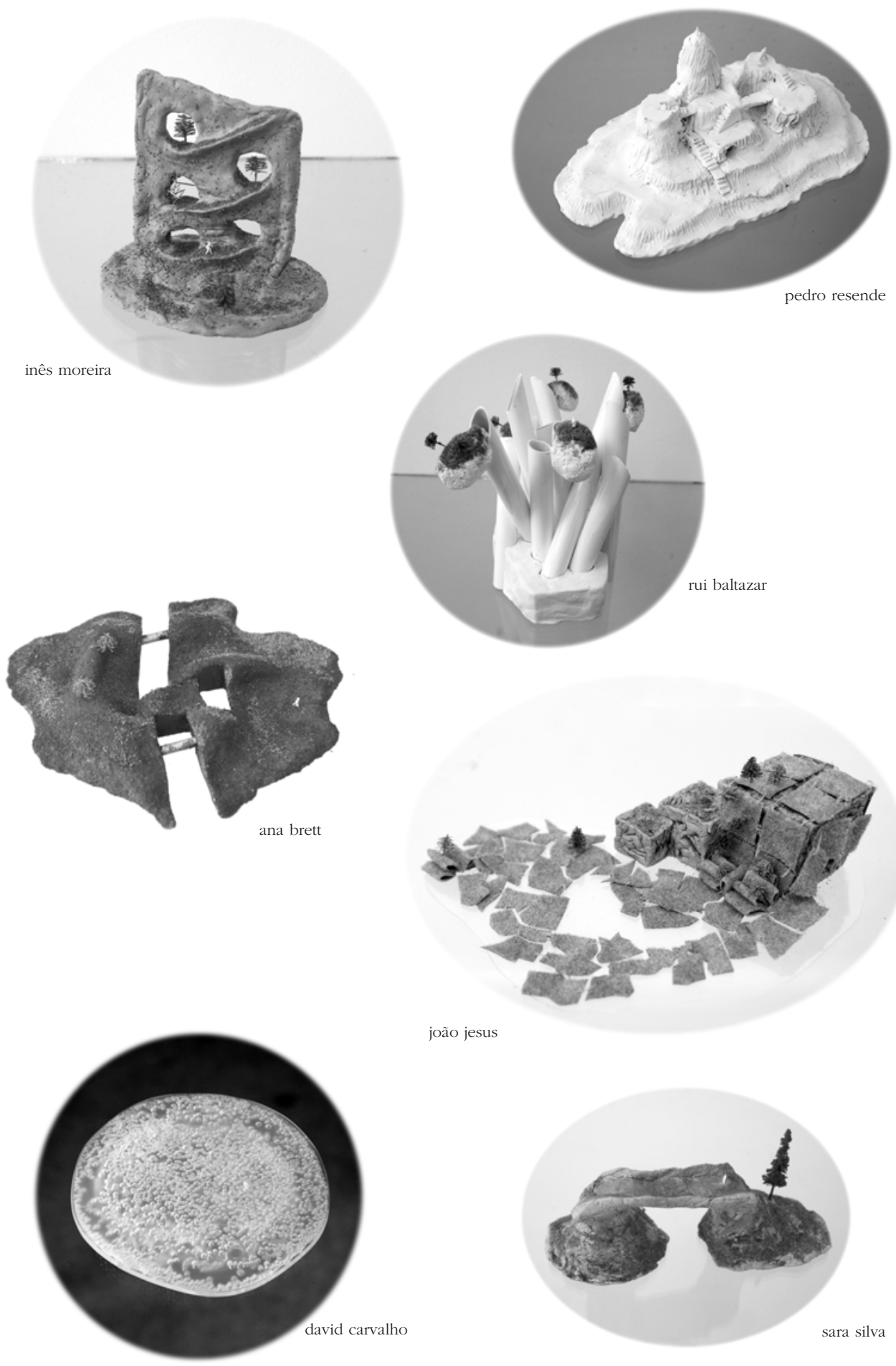

joão jesus

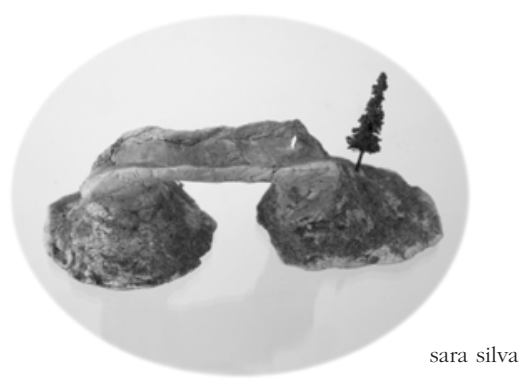



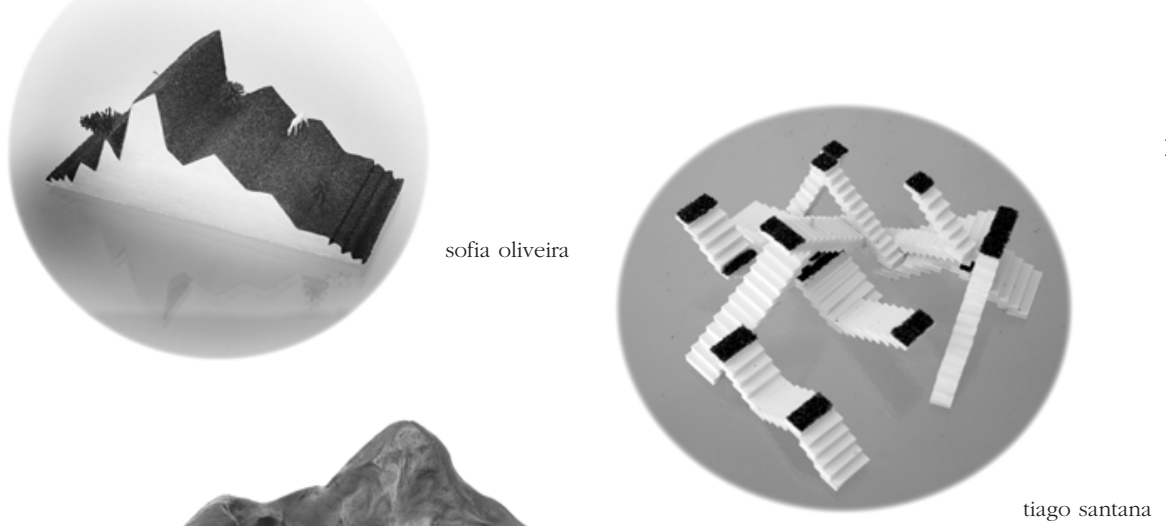

emmanuella quinta

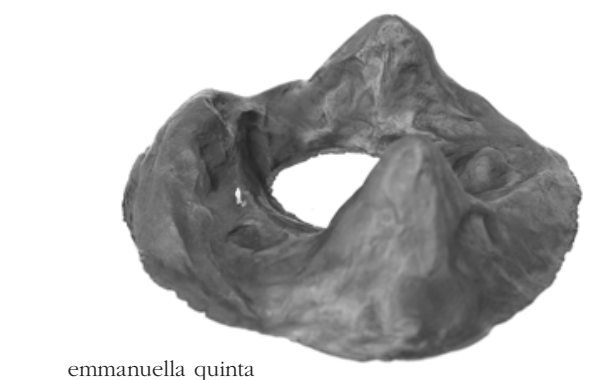

sofia oliveira
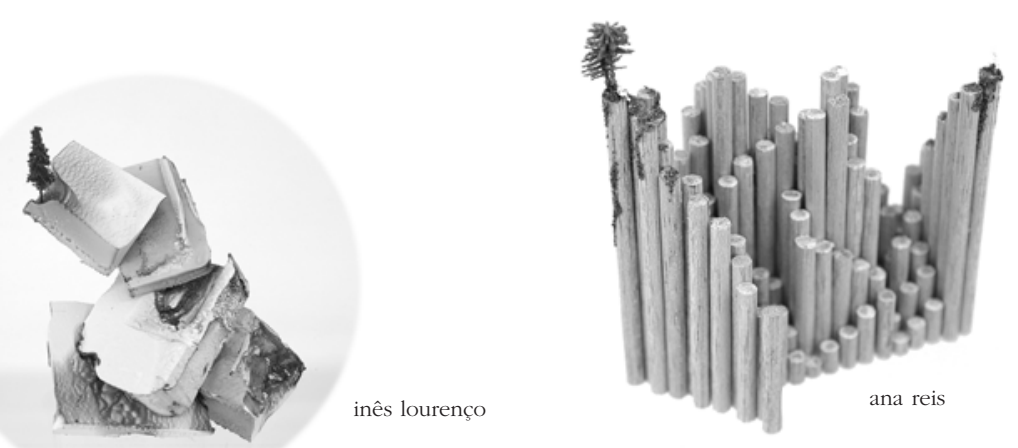

inês lourenço

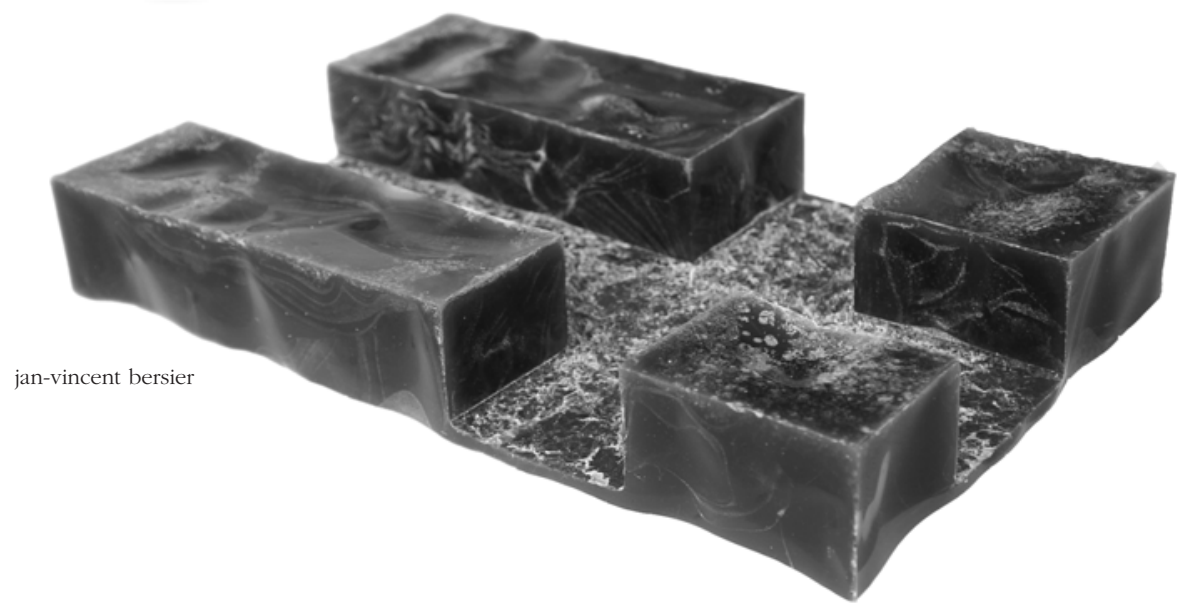


Série

Ensino

Imprensa da Universidade de Coimbra

Coimbra University Press

2006

- $\mathrm{U}$

(ivi

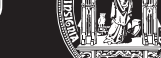

